\title{
The net prices of attendance at public institutions of higher learning and their relationships to family incomes
}

\author{
Edward Magee \\ West Virginia University
}

Follow this and additional works at: https://researchrepository.wvu.edu/etd

\section{Recommended Citation}

Magee, Edward, "The net prices of attendance at public institutions of higher learning and their relationships to family incomes" (2009). Graduate Theses, Dissertations, and Problem Reports. 2884. https://researchrepository.wvu.edu/etd/2884

This Dissertation is protected by copyright and/or related rights. It has been brought to you by the The Research Repository @ WVU with permission from the rights-holder(s). You are free to use this Dissertation in any way that is permitted by the copyright and related rights legislation that applies to your use. For other uses you must obtain permission from the rights-holder(s) directly, unless additional rights are indicated by a Creative Commons license in the record and/ or on the work itself. This Dissertation has been accepted for inclusion in WVU Graduate Theses, Dissertations, and Problem Reports collection by an authorized administrator of The Research Repository @ WVU.

For more information, please contact researchrepository@mail.wvu.edu. 
The Net Prices of Attendance at Public Institutions of Higher Learning and Their Relationships to Family Incomes

\author{
Edward Magee
}

Dissertation Submitted to the College of Human Resources and Education

At West Virginia University

Submitted in partial fulfillment of the requirements

for the degree of

\title{
Doctor of Education
}

in

Educational Leadership Studies

\author{
Richard Hartnett, Ed.D., Chair \\ David L. Dunlop, Ed.D. \\ Ernest Goeres, Ph.D. \\ Russell S. Sobel, Ph.D. \\ Richard T. Walls, Ph.D. \\ Department of Educational Leadership Studies
}

Morgantown, West Virginia

2009

Keywords: Higher Education Economics, Econometric, Market Theory, Public Higher Education 


\begin{abstract}
The Net Prices of Attendance at Public Institutions of Higher Learning and Their Relationships to Family Incomes

Edward Magee
\end{abstract}

Affordability of public higher education is a critical issue as the demand for college-educated citizens grows. This study examined the net prices paid by students to determine if affluent families pay less than market rates for public higher education. The history of public funding of higher education in the United States was studied to determine the historical sources of current public higher education funding policies. Current funding practices and the economic benefits of higher education were also examined.

A market theory for the funding streams of public higher education was developed as a framework for the analysis of public higher education finance. Price discrimination theory was used to construct this framework. The instructional services market as well as the markets for value provided to contributors, value provided to governments and the markets to attract students with certain characteristics to provide governmental funds to students were identified.

The relationship between the amounts of tuition and fees minus all grants, veteran, and tax benefits for students enrolled at private and public institutions and adjusted gross income was also examined.

The National Center for Educational Statistic's Integrated Postsecondary Educational Data System and National Postsecondary Student Aid Study and the Common Core of Data were used. In addition, data from the U.S. Census Bureau, Philanthropic Research, Inc., the National Conference of State Legislatures, and the National Association of State and University Land Grant Institutions were utilized.

The results from the instructional services market indicate that the determinants of tuition are similar for public and private institutions. Predictors of in-state tuition for both types of institutions include selectivity, Carnegie Foundation classifications, the per capita tax revenue for the state in which the school is operated and depreciation expenses. For out of state tuition, the common predictors are the same except for the per capita tax revenue for the state in which the school is operated.

The only common determinant of the equations for the market for value provided to contributors is depreciation expenses. Selectivity of private institutions is the only additional significant determinant for this market.

For the market for value provided to state governments, no significant determinants were identified for private institutions. Significant determinants for public institutions in this market are selectivity, the current enrollments as a percentage of the sum of the high-school graduates for the past four years, and depreciation expenses.

In the market for value provided to the federal government, depreciation expenses are determinants for public and private institutions. Additional determinants for private 
institutions are their status as 1862 land grant institutions and their Carnegie Foundation classifications.

In the market to Attract Students with Certain Characteristics, several common determinants were found for public and private institutions. Students' ages are determinants for all of the equations in this market. For merit-based aid, students' grade point averages are determinants. Adjusted gross income and the statuses of the students in relation to the state within which the schools are located are determinants for need-based aid. For both state and federal government need-based aid, the education levels of students' parents are significant determinants.

The relationship between the amounts of tuition and fees minus all grants, veteran, and tax benefits for students enrolled at private and public institutions and adjusted gross income is significant. This relationship is significant for both in-state and out-of-state students. In addition, the amounts of tuition and fees minus all grants, veteran, and tax benefits for students enrolled at private institutions is significantly higher than the tuition and fees minus all grants, veteran, and tax benefits for students enrolled at private institutions.

Students enrolled at public higher education institutions at all family income levels pay significantly less for their educations than students enrolled at private institutions. This phenomenon indicates that the public higher education markets are inefficient at all levels of family income. The gap between the amounts that students pay at public institutions compared to their counterparts enrolled at private schools is greater for students from more affluent families. This indicates that the tuition pricing policies in public higher education are inequitable and they favor higher income families. 


\section{ACKNOWLEDEGMENTS}

A project the size of a dissertation is not completed in isolation. Advice, encouragement, patience and understanding are needed from professors, family and friends. It is also helps to focus mainly on the task at hand rather than the end goal. I wish to thank Dr. Richard Hartnett, who supported my choice of a challenging dissertation topic that expanded my knowledge of higher education, economics, and statistics. Dr. David Dunlop in his capacity as President of Shepherd University provided wonderful insight as I developed the concept. Dr. Russell Sobel's knowledge of economics was the genesis of the higher education market theory. Dr. Ernest Goeres' knowledge of higher education finance was invaluable. Without Dr. Richard Wall's statistical advice and review, the journey would have been longer.

I must thank my father and mother, Alfred and Joyce Magee, for giving me the insight that studying could be enjoyable.

Above all, I wish to thank my wife Janet, and my children Claire and Mark. This dissertation would not have been possible without their love and support. 
Table of Contents

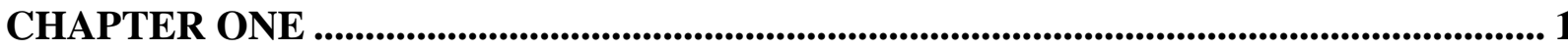

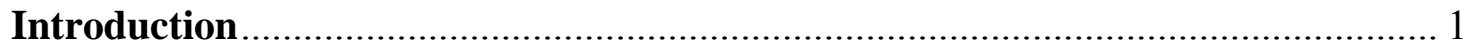

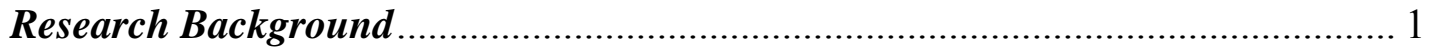

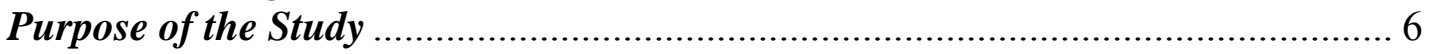

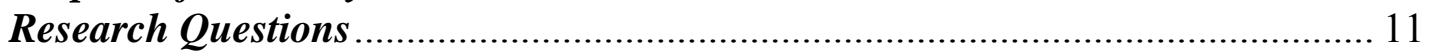

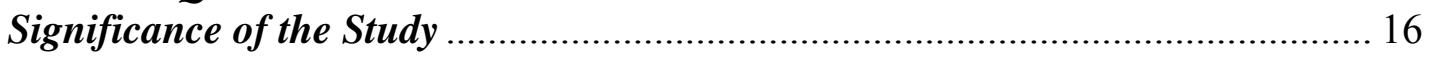

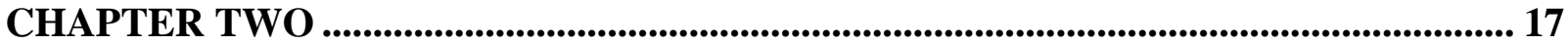

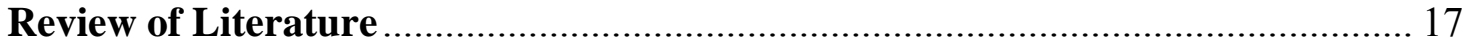

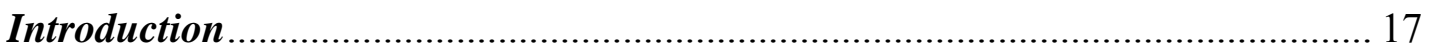

Political Foundations of Public Education in the United States ........................ 17

Public Education History ..................................................................... 18

Current Practices in Public Higher Education Finance .............................. 28

The Economic Benefits of Higher Education ............................................. 33

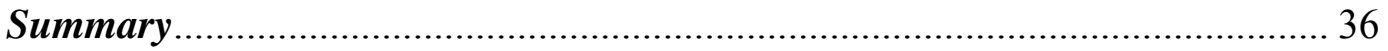

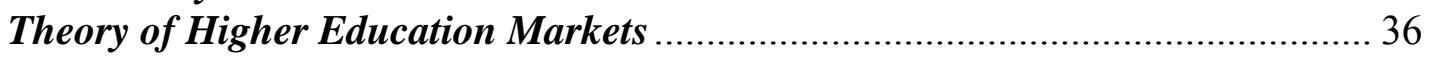

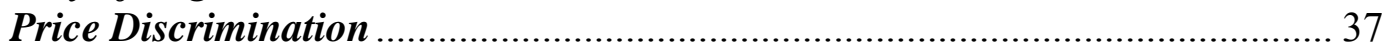

Conditions for Price Discrimination in Higher Education ............................ 38

Higher Education Markets ......................................................................... 39

Price Discrimination in relation to Higher Education Markets ...................... 43

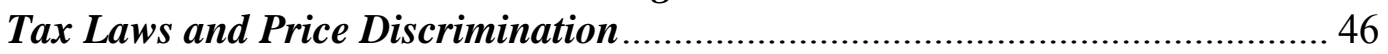

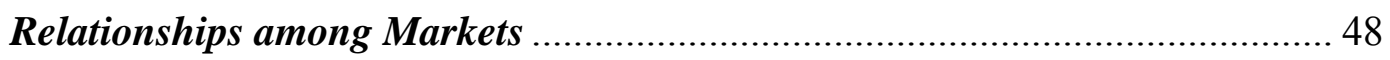

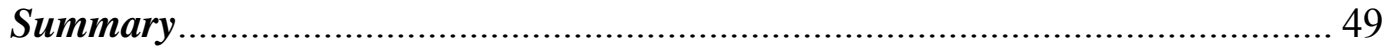

Research of the Determinants of Higher Education Markets ............................ 50

Instructional Services Market ................................................................... 51

Market for Value Provided to Contributors ................................................... 54

Market for Value Provided to Governments ...................................................... 61

Market to Attract Students with Certain Characteristics ................................ 64

State Subsidies of Public Higher Education .................................................. 71

Limitations of Previous Studies on Higher Education Econometric Models... 71

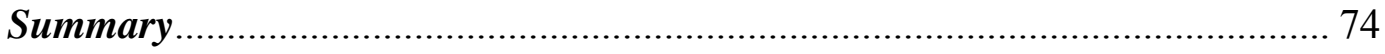

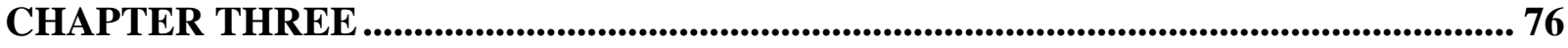

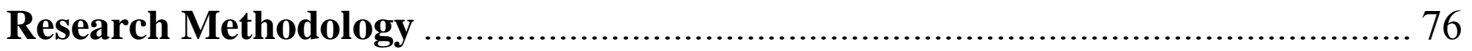

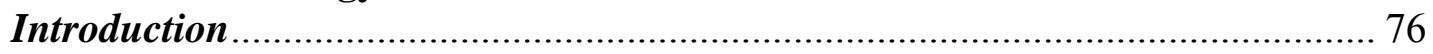

Econometric Models for Higher Education Markets ..................................... 76

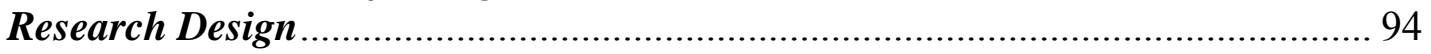

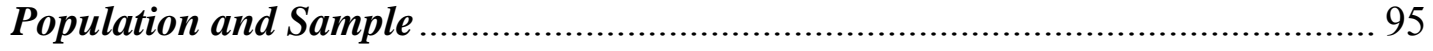

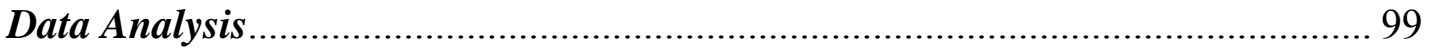

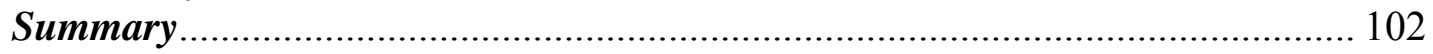

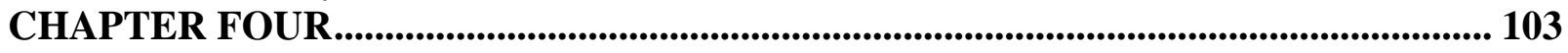

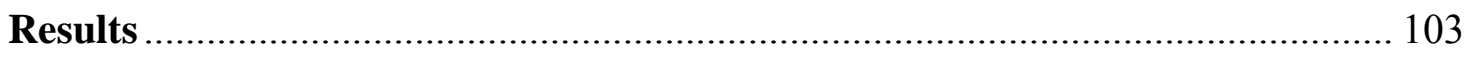

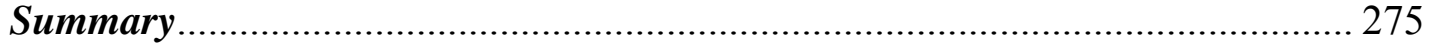

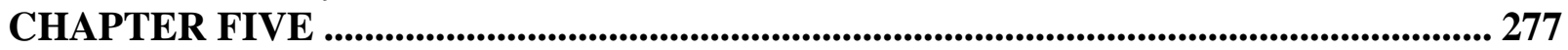


Summary, Findings, Conclusions, and Recommendations .......................... 277

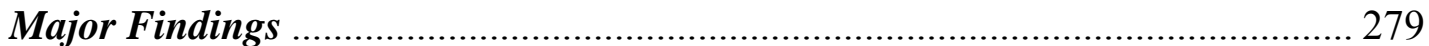

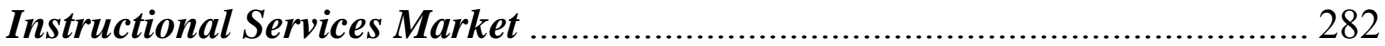

Market for Value Provided to Contributors ................................................ 287

Market for Value Provided to Governments ............................................... 289

Market to Attract Students with Certain Characteristics .............................. 291

Market to Provide Governmental Funds to Students ................................... 295

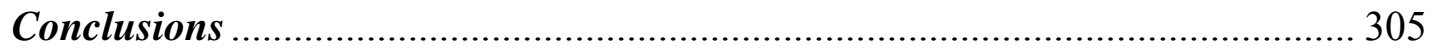

Recommendations .................................................................................... 310

Why Changes May Not Be Accepted ........................................................... 312

Recommendations for Further Research ........................................................ 313

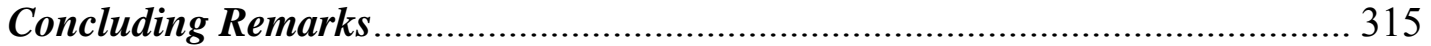

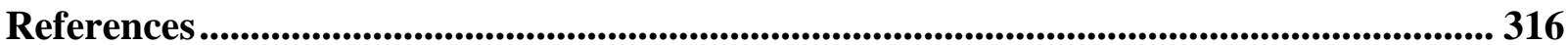

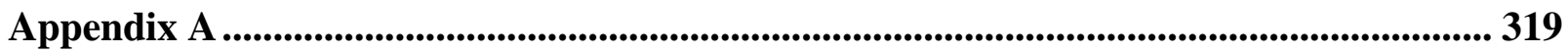

Appendix B: IPEDS Data Selection Criteria................................................................ 320

Appendix C: IPEDS Variables Used to Calculate Dissertation Variables ........................ 326

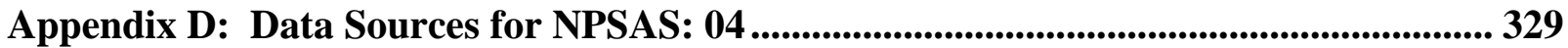

Appendix E: Variable Definitions ........................................................................... 330 


\section{List of Tables}

Table 1: Research question categories for equations 1a-af...................................... 78

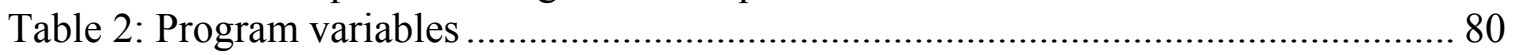

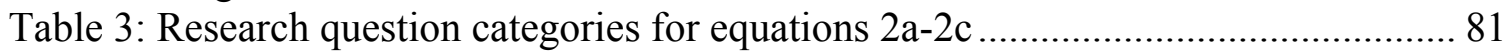

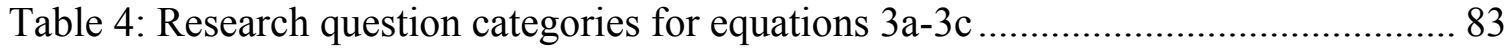

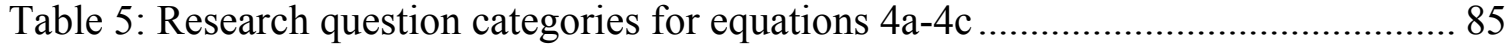

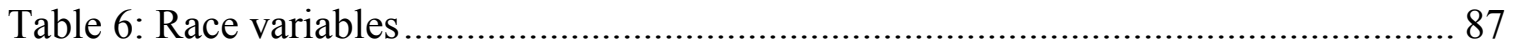

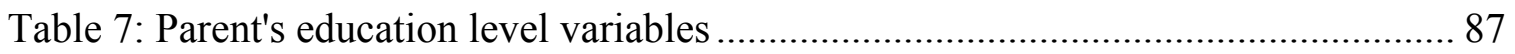

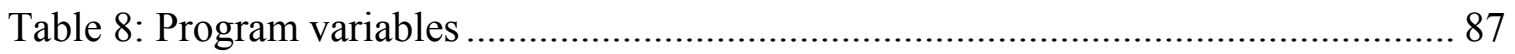

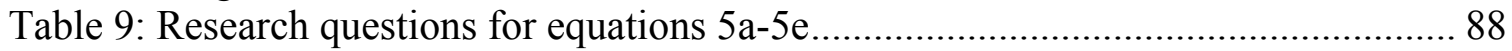

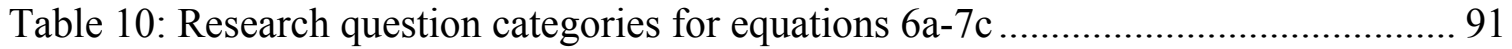

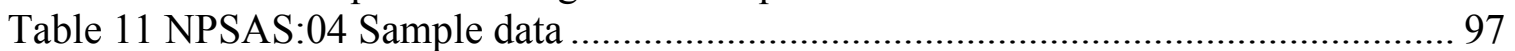

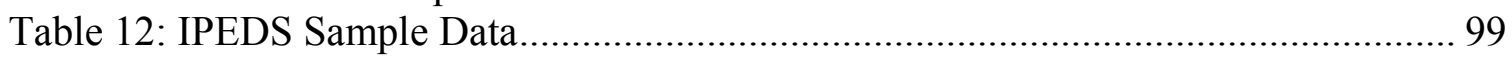

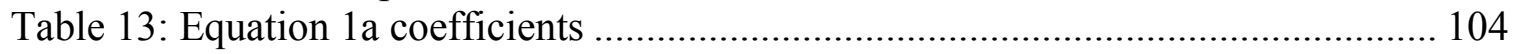

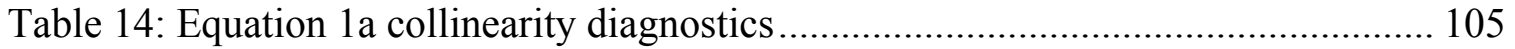

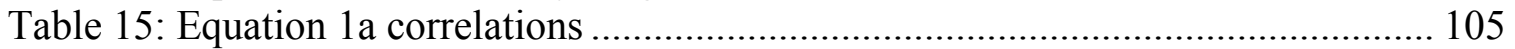

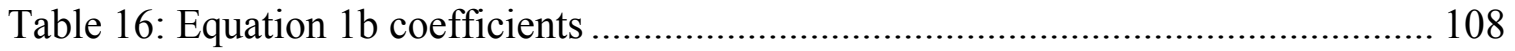

Table 17: Equation 1b second calculation coefficients............................................. 109

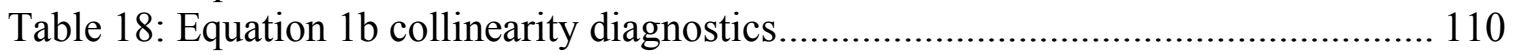

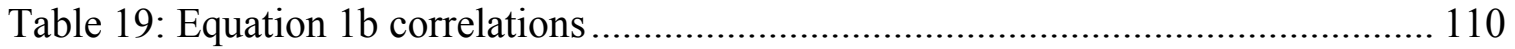

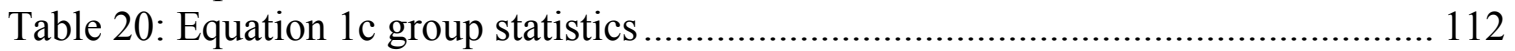

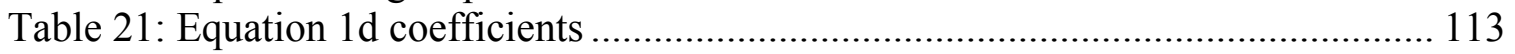

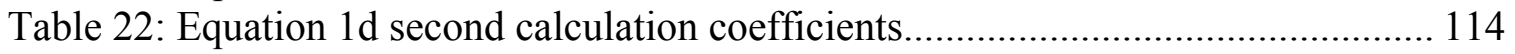

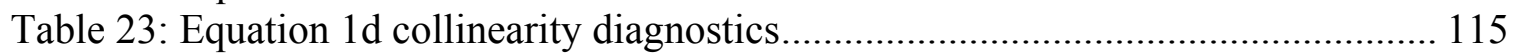

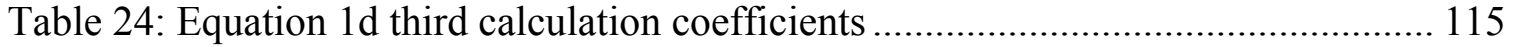

Table 25: Equation 1d third calculation collinearity diagnostics................................ 117

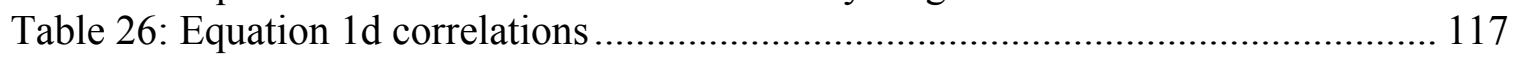

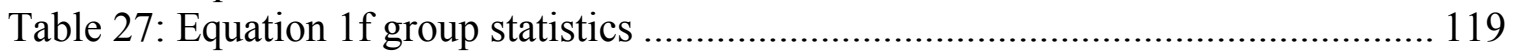

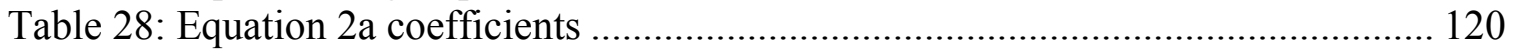

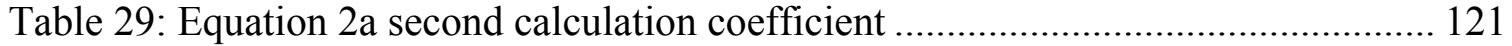

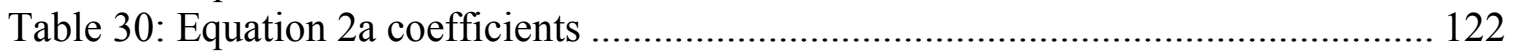

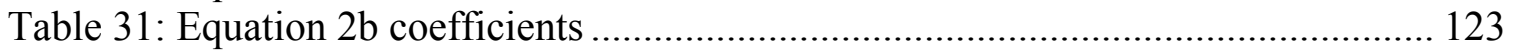

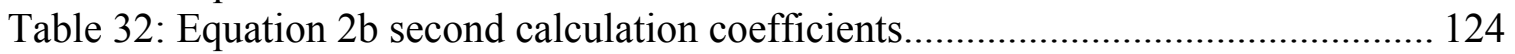

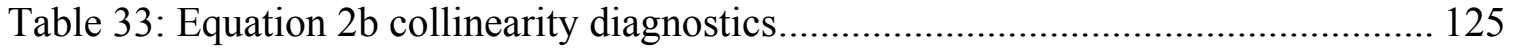

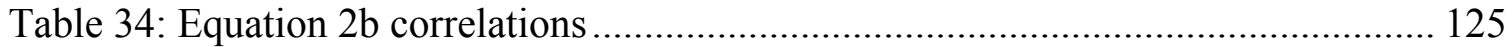

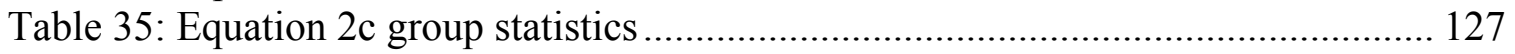

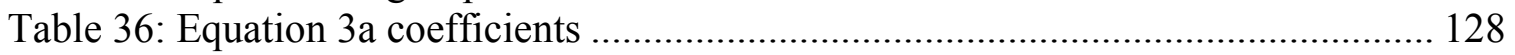

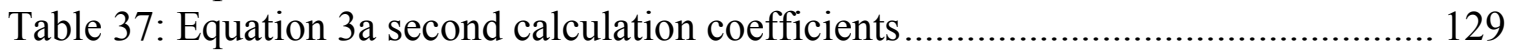

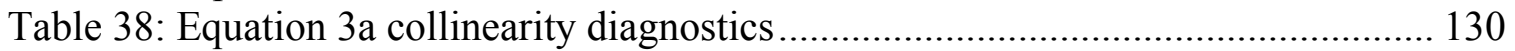

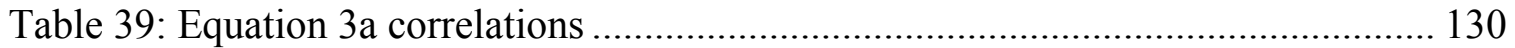

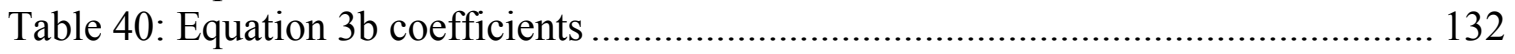

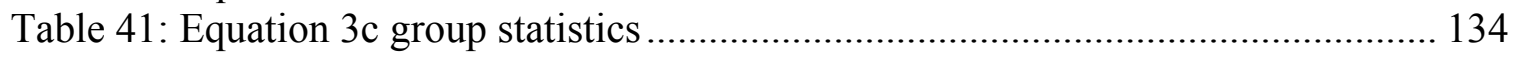

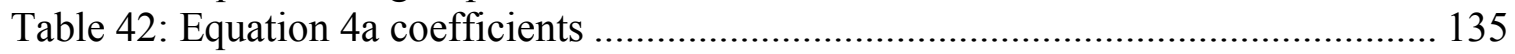

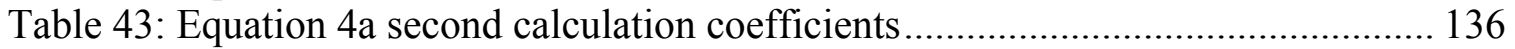

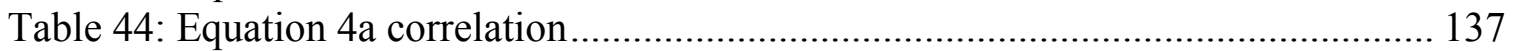




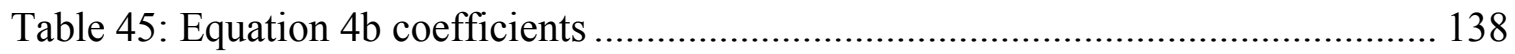

Table 46: Equation 4b second calculation coefficients................................................ 139

Table 47: Equation 4b collinearity diagnostics....................................................... 140

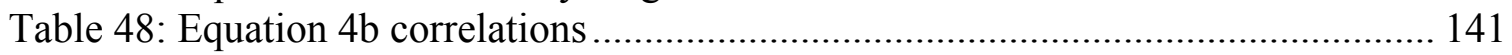

Table 49: Equation 4c group statistics ..................................................................... 142

Table 50: Equation 5a hypothesis testing results ....................................................... 143

Table 51: Equation 5a hypothesis testing results second calculation ............................. 144

Table 52: Equation 5a estimated full sample regression coefficients............................. 144

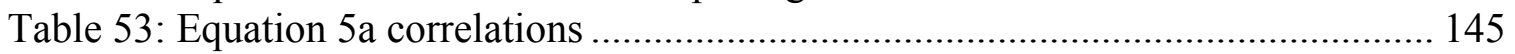

Table 54: Equation 5b hypothesis testing results....................................................... 147

Table 55: Equation 5b hypothesis testing results second calculation ............................. 148

Table 56: Equation 5b estimated full sample regression coefficients............................ 148

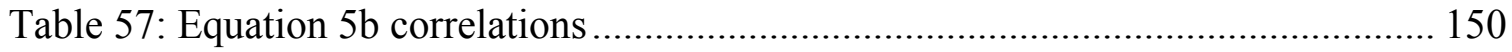

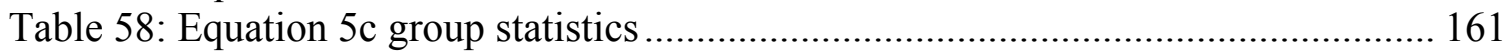

Table 59: Equation 5d hypothesis testing results........................................................ 162

Table 60: Equation 5d hypothesis testing results second calculation ............................. 162

Table 61: Equation 5d estimated full sample regression coefficients............................. 163

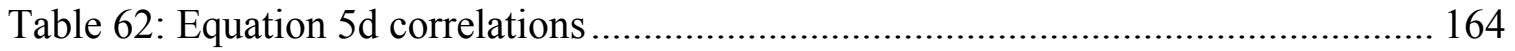

Table 63: Equation 5e hypothesis testing results ..................................................... 181

Table 64: Equation 5e hypothesis testing results....................................................... 182

Table 65: Equation 5e estimated full sample regression coefficients............................ 183

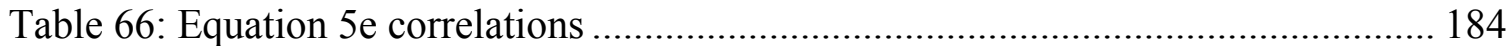

Table 67: Equation 5f group statistics .................................................................... 192

Table 68: Equation 6a hypothesis testing results........................................................ 192

Table 69: Equation 6a hypothesis testing results second calculation ............................. 193

Table 70: Equation 6a estimated full sample regression coefficients............................. 194

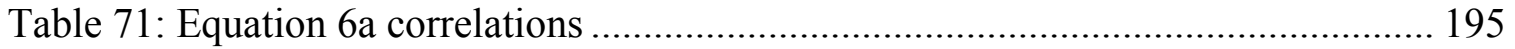

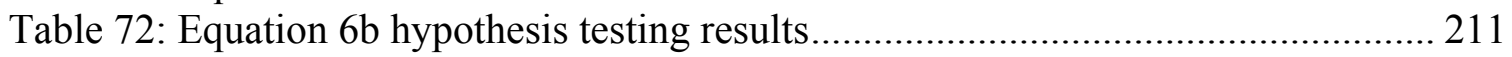

Table 73: Equation 6b hypothesis testing results second calculation ............................. 211

Table 74: Equation 6b estimated full sample regression coefficients............................. 212

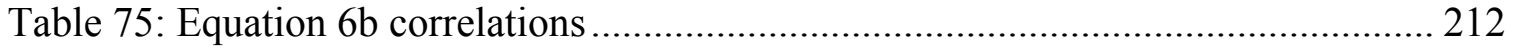

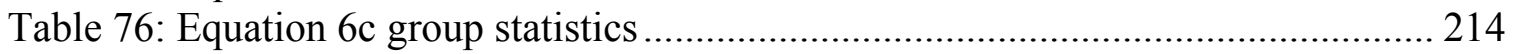

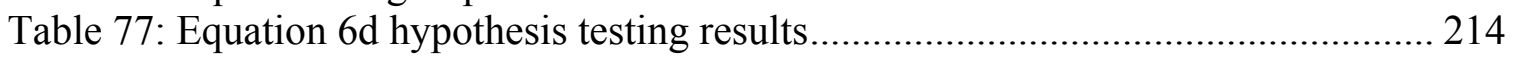

Table 78: Equation 6d estimated full sample regression coefficients............................. 215

Table 79: Equation 6d correlations ...................................................................... 217

Table 80: Equation 6e hypothesis testing results....................................................... 234

Table 81: Equation 6e hypothesis testing results second calculation ............................. 235

Table 82: Equation 6e hypothesis testing results third calculation.................................. 235

Table 83: Equation 6e estimated full sample regression coefficients............................. 236

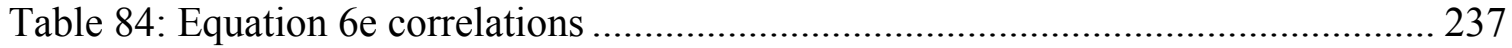

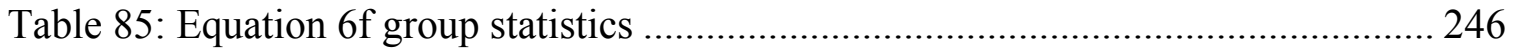

Table 86: Equation 7a hypothesis testing results ....................................................... 246

Table 87: Equation 7a hypothesis testing results second calculation ............................ 247

Table 88: Equation 7a estimated full sample regression coefficients............................. 248

Table 89: Equation 7a correlations ......................................................................... 249

Table 90: Equation 7b hypothesis testing results....................................................... 258 
Table 91: Equation $7 \mathrm{~b}$ hypothesis testing results second calculation ..........................2 258

Table 92: Equation 7b estimated full sample regression coefficients.........................259

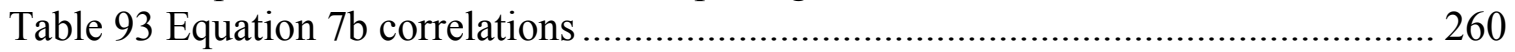

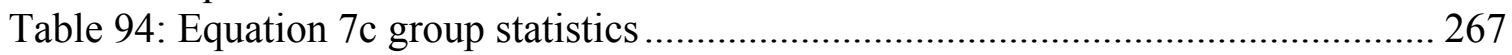

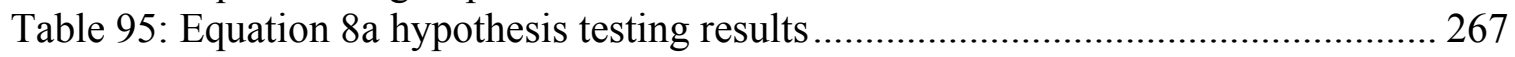

Table 96: Equation 8a estimated full sample regression coefficients.......................... 268

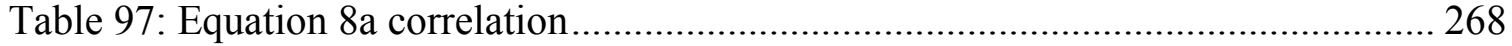

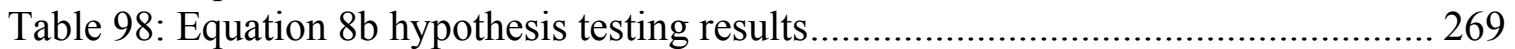

Table 99: Equation 8b estimated full sample regression coefficients........................... 269

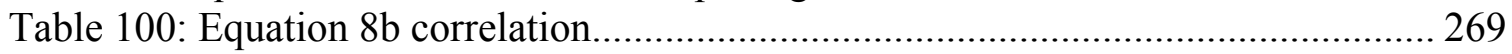

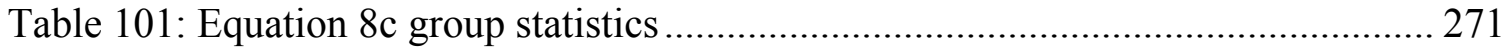

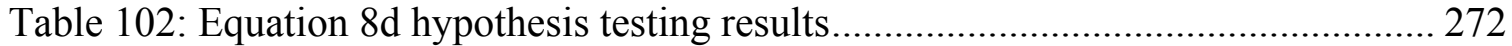

Table 103: Equation 8d estimated full sample regression coefficients........................ 272

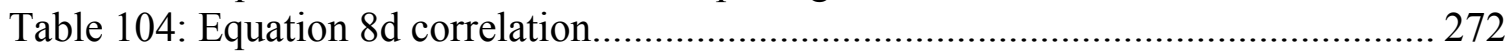

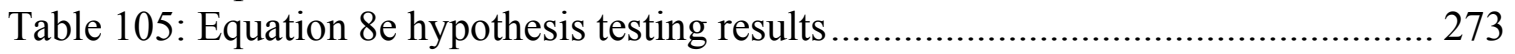

Table 106: Equation 8e estimated full sample regression coefficients........................ 273

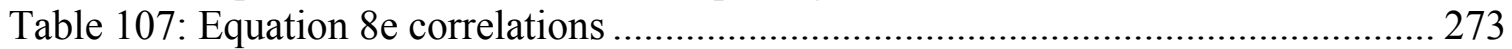

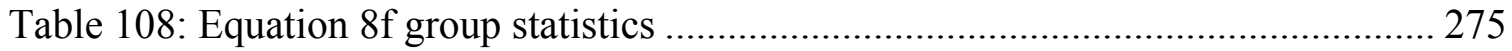

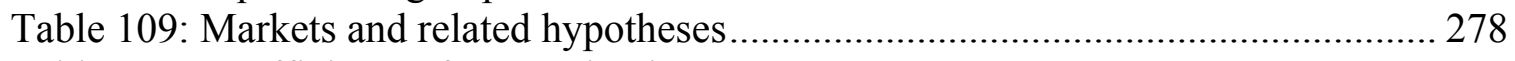

Table 110: Coefficients of Determination .................................................................. 279

Table 111: Difference Between the Means Results ....................................................... 280

Table 112: Equation 5b parent's education levels and changes in dependent variables . 292

Table 113: Equation 5e programs and changes in dependent variables ........................ 294

Table 114: Equation 6a parents education levels and changes in dependent variables .. 296

Table 115: Equation 6a programs and changes in dependent variables ....................... 297

Table 116: Equation 6d parent's education levels and changes in dependent variables . 299

Table 117 Equation 6e parent's education level and changes in dependent variables .... 299

Table 118: Equation 7a parent's educational level and changes in dependent variables 301

Table 119: Equation 7b parent's education level and changes in dependent variables... 302 


\section{List of Figures}

Figure 1: State appropriations as a percentage of total taxes............................................ 32

Figure 2: Resources flows in higher education markets ........................................... 50

Figure 3: Adjusted gross income versus tuition minus grants, veteran's and tax benefits.... 305 


\section{CHAPTER ONE}

\section{Introduction}

\section{Research Background}

State governments are frequently criticized for their failure to promote access to institutions of higher learning. This criticism has become more pronounced as the demand for skilled and educated employees has increased. Salaries of workers with degrees from institutions of higher learning have increased relative to those workers with only high school diplomas (Day $\&$ Newburger, 2002). The urgency to reform higher education has been amplified by the need to ensure that citizens attain higher levels of income. Higher education is often expected to be an economic engine that develops human capital (Miller, 2006).

To achieve their economic development goals, states must ensure that higher education is available to students from poor families. Access is limited for several reasons. Low-income families may not be aware of financial aid programs or they may not consider the possibility that their children could enroll in a college or university (Courant, McPherson, \& Resch, 2006). The complexity of financial aid rules limits access to low-income families (Miller, 2006).

The diminished affordability of higher education also reduces the attendance of students from low-income families. Affordability has been defined as how closely the tuition costs minus financial aid matches the families' ability to pay for postsecondary education. According to the Lumina Foundation, "Declining affordability discourages many low-income students from enrolling in challenging high school courses and even from graduating from high school." This organization has issued failing grades for affordability to all but seven states (Measuring Up 2006, 2006, p. 19). 
Although legislatures have passed many bills to improve affordability, the resulting laws have not produced the desired results. States have failed because the multiple factors that affect affordability have not been addressed in a cohesive manner (Jones, 2003). For public institutions, affordability is influenced by tuition prices, financial aid, and the level of direct appropriations to higher education. Tuition prices at state institutions seem to be set at below market levels to attract applicants from a wide range of economic backgrounds. State governments have also created scholarship programs based on financial need to expand the availability of postsecondary education. Increases in direct state appropriations have had a tendency to ameliorate tuition increases (Koshal \& Koshal, 2000).

It is important for states to develop effective financing policies for higher education. Unintended outcomes may result from broad polices that have not been applied to sufficiently narrow targets. In the effort to provide higher education for as many citizens as possible, state governments may extend benefits to citizens who do not need assistance. By setting tuitions at a low level for all citizens, affluent families may pay below-market rates for their childrens' education.

In addition, policies that are difficult for citizens to understand may also produce results that are not planned. Complex rules and formulas may discourage program participation. If parents and guardians do not understand the mechanics of scholarship programs, they may not encourage their children to prepare for higher education.

These unintended outcomes may be a result of a scattered and piecemeal approach to the development of higher education finance policies (Jones, 2003). Moreover, states may lack sound principals for the development of higher education financing policies. Usually states address tuition, financial aid, and appropriations separately. 
A cohesive approach to policy development can be created within a theoretical framework. A goal of this framework is to construct a method to maximize available resources for the development of human capital. The development of a human capital base should increase a state government's tax revenues in the long run as the income levels of its citizens' improves. Theoretically, the prices that could be charged for tuition will increase and the need-based financial aid costs will diminish as a state's average income level increases. Higher tuition prices and lower financial aid costs could allow a state government to reduce the amount of state appropriations provided to colleges and universities.

The promotion of economic and social benefits through the development of human capital should drive the formulation of public higher education financial strategies. Optimal levels of tuition prices, scholarship aid, state appropriations, federal revenues, and private contributions become the framework's economic structural components. If states intend for postsecondary education to be a driving force in the development of human capital, higher education finance policies must be tailored to meet the states' goals. The mix of resources from taxes, tuition and fees, and donations should be maximized to provide the optimal distribution of resources. The economic activities related to tuition prices, donations, governmental funds and, financial aid must be understood.

Tuition prices should be set at a level that will maximize the revenue received from affluent families. This policy supports the "high tuition-high aid" strategy. "This approach involves setting public tuition at levels that come close (or closer) to covering costs, and then providing substantial means-tests subsidies for students from families of low income or moderate income" (Courant et al., 2006, p. 309). If tuitions are kept low, the opportunity to provide scholarships to low income students is hindered. 
It may be difficult politically to increase tuition prices for affluent families. Pressure may exist to encourage excellent students' attendance at public institutions. A state's policy makers may believe that many of these students will continue to live in the state after graduation and make positive contributions to its economy.

Tuition prices for out-of-state students should also be considered. The prices for these students should typically be set at a level that will maximize revenues. "There are many instances in which institutions are deemed particularly attractive by out-of-state students. In such circumstances, institutions are in a position to charge what the market will bear" (Jones, 2003, p. 14). On the other hand, states may wish to charge below-market tuition rates to non-residents students for economic development purposes or to strengthen institutions. Students from other states may contribute financial resources to the local economy. If schools are operating at less than capacity, the enrollment of additional non-resident students can increase the institutions' efficiency.

In addition to policies for tuition prices, it is also important to address the direct funding of institutions. State appropriations should be set at a level that maximizes the intended outcomes from state support of higher education (Jones, 2003). The intended outcomes may include the development of human capital and the minimization of the tax burden. The desire to minimize the tax burden on state citizens has increased over time. State support of higher education has decreased 30 percent since the late 1970s. Many states have introduced laws limiting state government spending to an external indicator such as the state's level of personal income (Archibald \& Feldman, 2006). The ability of governments to increase corporate taxes has diminished as the willingness of corporations to relocate to more favorable locations has changed (Johnstone, 2002). To minimize the tax burden and leverage the state's investment, the optimal 
levels of tuition, scholarships, federal aid, and tax credits must be balanced with the need for quality educational services. To promote efficiency, state governments should determine the optimal mix of institutions in relation to size and mission.

Contributions augment revenues from appropriations and tuition revenues. Public colleges and universities should solicit donations from individuals and organizations to satisfy their need to provide philanthropic support for higher education. The cultivation of these resources can reduce the level of tuition and appropriations required for operations.

Revenue polices cannot be considered without considering the level of quality desired by a state government. The quality of educational services at state institutions should be set at a level to ensure an optimal return on the investment made by the state and families. Colleges and universities need adequate funding to hire competent staff, buy necessary equipment, and maintain physical plant facilities (Johnstone, 2002). Institutions may need to provide scholarships to highly qualified students to enhance learning. To elevate the quality and efficiency levels of colleges and universities, primary and secondary schools should maximize the educational levels of their graduates.

Scholarship aid for low-income students should be set at a level that will maximize their attendance at colleges or universities. "The practical policy challenge is to provide adequate public subsidy for those students who would otherwise be discouraged from making socially desirable investments in further education" (Courant et al., 2006, p. 309). The amount of aid provided should not reduce the amount of federal aid that students receive. "By taking advantage of the federal programs (specifically the Pell need-based aid program), states can leverage their own programs" (Jones, 2003, p. 8). It may also be necessary to consider the effects of federal higher education tax credits which reduce the cost of attendance. The promotion of economic 
development should not be the only goal addressed by public higher education financial policies. Many goals cannot easily be measured in economic terms. For example, citizens need to be educated and have a sufficient understanding of ethics and the political system to elect officials who will act in their best interest.

Tuition and appropriations policies should be examined to ensure that they do not give any group of citizens an unfair advantage. The ratio of the price of education to the average incomes of families has been studied (Measuring Up 2006, 2006). Very little research has been conducted to determine if the price, net of financial aid, paid by more affluent families exceeds their expected contributions at public institutions.

Because few studies have considered whether affluent families are paying a fair amount for the educational services their children receive, state governments may be needlessly limiting institutions' revenues. The unrealized revenues could be used to increase scholarships for low-income students or reduce the level of state appropriations otherwise required for the operations of state college and universities.

\section{Purpose of the Study}

The literature reflects the need for state governments to coordinate tuition pricing, scholarship, and state appropriation funding levels to maximize human capital. Furthermore, articles have reflected concerns regarding the potential undercharging of tuition and fees to affluent families. The possibility that merit aid may be awarded to students who would have paid the state tuition price has also been discussed.

The pricing of in-state tuition for colleges and universities of selected states is the focus of this study. The data were collected from the 2004 National Postsecondary Student Aid Study 
(NPSAS:04) conducted by the National Center for Educational Statistics (NCES), the Integrated Postsecondary Institutional Data System (IPEDS) maintained by the NCES, the Common Core of Data maintained by the NCES, the U.S. Census Bureau, the National Association of State Universities and Land Grant Colleges, Philanthropic Research, Inc., and the National Conference of State Legislatures.

The purpose of this study was to determine if governmental expenditures for human capital development in higher education markets are allocated efficiently. Specifically, do affluent families pay less than market rates for public higher education? To answer this question, it was necessary to examine the structures and activities of the markets that form the higher education economy.

Hypothesis $\left(\mathrm{H}_{1 \mathrm{a}}\right)$ of the study was that no statistically significant relationship exists between the amount of tuition and fees per student charged to in-state students by public institutions, institutional characteristics, and the economic and political characteristics of the states. Hypothesis $\left(\mathrm{H}_{1 \mathrm{~b}}\right)$ of the study was that no statistically significant relationship exists between the amount of tuition and fees per student charged to in-state students by private institutions, institutional characteristics, and the economic and political characteristics of the states. Hypothesis $\left(\mathrm{H}_{1 \mathrm{c}}\right)$ was that tuition and fees per student charged to in-state students by public institutions is less than or equal to the tuition and fees charged to in-state students by private institutions. Hypothesis $\left(\mathrm{H}_{1 \mathrm{~d}}\right)$ of the study was that no statistically significant relationship exists between the amount of tuition and fees per student charged to out-of-state students by public institutions, institutional characteristics, and the economic and political characteristics of the states. Hypothesis $\left(\mathrm{H}_{1 \mathrm{e}}\right)$ of the study was that no statistically significant relationship exists between the amount of tuition and fees per student charged to out-of-state students by 
private institutions, institutional characteristics, and the economic and political characteristics of the states. Hypothesis $\left(\mathrm{H}_{1 \mathrm{f}}\right)$ was that tuition and fees per student charged to out-of-state students by public institutions is less than or equal to the tuition and fees charged to out-ofstate students by private institutions. Hypothesis $\left(\mathrm{H}_{2 \mathrm{a}}\right)$ was that no significant relationship exists between the amount of revenues collected from private donations per student by public institutions, institutional characteristics, and academic programs. Hypothesis $\left(\mathrm{H}_{2 b}\right)$ was that no significant relationship exists between the amount of revenues collected from private donations per student by private institutions, institutional characteristics, and academic programs. Hypothesis $\left(\mathrm{H}_{2 \mathrm{c}}\right)$ was that the private donations per student by public institutions is less than or equal to the private donations received by private institutions. Hypothesis $\left(\mathrm{H}_{3 \mathrm{a}}\right)$ was that there is no significant relationship between the amount of state appropriations per student received by public institutions, institutional characteristics, the economic and political characteristics of the states in which the institutions operate, academic programs, and the available pools of students within the states. Hypothesis $\left(\mathrm{H}_{3 \mathrm{~b}}\right)$ was that there is no significant relationship between the amount of state appropriations per student received by private institutions, institutional characteristics, the economic and political characteristics of the states in which the institutions operate, academic programs, and the available pools of students within the states. Hypothesis $\left(\mathrm{H}_{3 \mathrm{c}}\right)$ is that the amount of state appropriations received by private institutions is less than or equal to the amount of state appropriations received by public institutions. Hypothesis $\left(\mathrm{H}_{4 \mathrm{a}}\right)$ was that there is no significant relationship between the amount of federal revenues received by public institutions, their statuses as land grant institutions, institutional characteristics, and academic programs. Hypothesis $\left(\mathrm{H}_{4 b}\right)$ was that there is no significant relationship between the amount of federal revenues received by 
private institutions, their statuses as land grant institutions, institutional characteristics, and academic programs. Hypothesis $\left(\mathrm{H}_{4 \mathrm{c}}\right)$ was that the amount of federal revenues received by private institutions is less than or equal to the amount of federal revenues received by public institutions. Hypothesis $\left(\mathrm{H}_{5 \mathrm{a}}\right)$ was that there is no significant relationship between institutional merit-based financial grant aid per student paid by public institutions, student characteristics, and academic programs. Hypothesis $\left(\mathrm{H}_{5 \mathrm{~b}}\right)$ was that there is no significant relationship between institutional merit-based financial grant aid paid per student by private institutions, student characteristics, and academic programs. Hypothesis $\left(\mathrm{H}_{5 \mathrm{c}}\right)$ was that the amount of institutional merit-based financial grant aid paid per student by public institutions is less than or equal to the amount of institutional merit-based financial grant aid paid per student by private institutions. Hypothesis $\left(\mathrm{H}_{5 \mathrm{~d}}\right)$ was that there is no significant relationship between institutional need-based financial grant aid paid per student by public institutions, student characteristics, and academic programs. Hypothesis $\left(\mathrm{H}_{5 \mathrm{e}}\right)$ was that there is no significant relationship between institutional need-based financial grant aid paid per student by private institutions, student characteristics, and academic programs. Hypothesis $\left(\mathrm{H}_{5 \mathrm{f}}\right)$ was that the amount of institutional need-based financial grant aid paid per student by public institutions is less than or equal to the amount of institutional need-based financial grant aid paid per student by private institutions. Hypothesis $\left(\mathrm{H}_{6 \mathrm{a}}\right)$ was that there is no significant relationship between the amount of state merit-based financial grant aid received per student at public institutions, the amount of tuition and fees per student charged to in-state students, student characteristics, and academic programs. Hypothesis $\left(\mathrm{H}_{6 \mathrm{~b}}\right)$ was that there is no significant relationship between the amount of merit-based state financial grant aid received per student at public institutions, the amount of tuition and the fees per student charged to in- 
state students, student characteristics, and academic programs. Hypothesis $\left(\mathrm{H}_{6 c}\right)$ was that the amount of state merit-based financial grant aid per student received at public institutions was less than or equal to the amount of state merit-based grant aid per student received at private institutions. Hypothesis $\left(\mathrm{H}_{6 \mathrm{~d}}\right)$ was that there is no significant relationship between the amount of state need-based financial grant aid received per student at public institutions, the amount of tuition and fees per student charged to in-state students, student characteristics, and academic programs. Hypothesis $\left(\mathrm{H}_{6 \mathrm{e}}\right)$ was that there is no significant relationship between the amount of need-based state financial grant aid received per student at public institutions, the amount of tuition and the fees per student charged to in-state students, student characteristics and academic programs. Hypothesis $\left(\mathrm{H}_{6 \mathrm{f}}\right)$ was that the amount of state needbased financial grant aid per student received at private institutions was less than or equal to the amount of state need-based financial grant aid per student received at public institutions. Hypothesis $\left(\mathrm{H}_{7 \mathrm{a}}\right)$ was that there is no significant relationship between the amount of federal grants, veteran, and tax benefits received per student by public institutions, the amount of tuition and fees per student charged to in-state students, student characteristics, and the economic and political characteristics of the states. Hypothesis $\left(\mathrm{H}_{7 \mathrm{~b}}\right)$ was that there is no significant relationship between the amount of federal grants, veteran, and tax benefits received per student by private institutions, the amount of tuition and fees per student charged to in-state students, student characteristics, and the economic and political characteristics of the states. Hypothesis $\left(\mathrm{H}_{7 \mathrm{c}}\right)$ was that the amount of federal grants, veterans and tax benefits received per student at public institutions was less than or equal to the amount of federal grants, veterans and tax benefits received per student at private institutions. Hypothesis $\left(\mathrm{H}_{8 \mathrm{a}}\right)$ was that there is no significant relationship between tuition and fees minus 
all grants, veteran, and tax benefits for in-state students enrolled at public institutions and adjusted gross income. Hypothesis $\left(\mathrm{H}_{8 \mathrm{~b}}\right)$ was that there is no significant relationship between tuition and fees minus all grants, veteran, and tax benefits for in-state students enrolled at private institutions and adjusted gross income. Hypothesis $\left(\mathrm{H}_{8 \mathrm{c}}\right)$ was that amount of tuition and fees minus all grants, veteran, and tax benefits for in-state students at public institutions was less than or equal to the amount of tuition and fees minus all grants, veteran, and tax benefits for in-state students at private institutions. Hypothesis $\left(\mathrm{H}_{8 \mathrm{~d}}\right)$ was that there is no significant relationship between tuition and fees minus all grants, veteran, and tax benefits for out-of-state students enrolled at public institutions and adjusted gross income. Hypothesis $\left(\mathrm{H}_{8 \mathrm{e}}\right)$ was that there is no significant relationship between tuition and fees minus all grants, veteran, and tax benefits for out-of-state students enrolled at private institutions and adjusted gross income. Hypothesis $\left(\mathrm{H}_{8 \mathrm{f}}\right)$ was that the amount of tuition and fees minus all grants, veteran, and tax benefits for out-of-state students at public institutions was less than or equal to the amount of tuition and fees minus all grants, veteran, and tax benefits for out-of-state students at private institutions.

\section{Research Questions}

1a. Is there a statistically significant relationship between the amount of tuition and fees per student charged to in-state students by public institutions, institutional characteristics, and the economic and political characteristics of the states?

1b. Is there a statistically significant relationship between the amount of tuition and fees per student charged to in-state students by private institutions, institutional characteristics, and the economic and political characteristics of the states? 
1c. Does the amount of tuition and fees per student charged to in-state students at private institutions differ significantly from the in-state tuition charged to in-state students at public institutions?

1d. Is there a statistically significant relationship between the amount of tuition and fees per student charged to out-of-state students by public institutions, institutional characteristics and the economic and political characteristics of the states?

1e. Is there a statistically significant relationship between the amount of tuition and fees per student charged to out-of-state students by private institutions, institutional characteristics, and the economic and political characteristics of the states?

1f. Do the amounts of tuition and fees per student charged to out-of-state students at private institutions differ significantly from the out-of-state tuition charged to out-of-state students at public institutions?

2a. Is there a statistically significant relationship between the amount of revenues collected from private donations per student by public institutions, institutional characteristics, and academic programs?

$2 \mathrm{~b}$. Is there a statistically significant relationship between the amount of revenues collected from private donations per student by private institutions, institutional characteristics, and academic programs?

2c. Do the amount of revenues collected from private donations per student by private institutions differ significantly from the amount of revenues collected from private donations per student donations received by public institutions?

3a. Is there a statistically significant relationship between the amount of state appropriations per student received by public institutions, institutional characteristics, the economic and 
political characteristics of the states in which the institutions operate, academic programs, and the available pools of students within the states?

3b. Is there a statistically significant relationship between the amount of state appropriations per student received by private institutions, institutional characteristics, the economic and political characteristics of the states in which the institutions operate, academic programs, and the available pools of students within the states?

3c. Do the state appropriations per student received by public institutions differ significantly from the state appropriations received by private institutions?

4a. Is there a significant relationship between the amount of federal revenues received by public institutions, their statuses as land grant institutions, institutional characteristics, and academic programs?

4b. Is there a significant relationship between the amount of federal revenues received by private institutions, their statuses as land grant institutions, institutional characteristics, and academic programs?

4c. Do the federal revenues received by public institutions differ significantly from the federal revenues received by private institutions?

5a. Is there a significant relationship between institutional merit-based financial grant aid paid per student by public institutions, student characteristics, and academic programs?

5b. Is there a significant relationship between institutional merit-based financial grant aid paid per student by private institutions, student characteristics, and academic programs?

5c. Do the amounts paid for institutional merit-based financial grant aid paid per student by public institutions differ significantly from the amounts paid for institutional merit-based financial grant aid paid per student by private institutions? 
5d. Is there a significant relationship between institutional need-based financial grant aid paid per student by public institutions, student characteristics, and academic programs?

5e. Is there a significant relationship between institutional need-based financial grant aid paid per student paid by private institutions, student characteristics, and academic programs?

5f. Do the amounts paid for institutional need-based financial grant aid paid by public institutions differ significantly from the amounts paid for institutional need-based financial grant aid by private institutions?

6a. Is there a relationship between the amount of state merit-based financial grant aid received per student at public institutions, the amount of tuition and the fees per student charged to in-state students, student characteristics and academic programs?

$6 \mathrm{~b}$. Is there a relationship between the amount of state merit-based financial grant aid received at private institutions, the amount of tuition and the fees per student charged to in -state students, student characteristics and academic programs?

6c. Does the amount of state merit-based financial grant aid received by students at public institutions differ significantly from the amount of state merit- based financial grant aid receive by students at private institutions?

$6 \mathrm{~d}$. Is there a relationship between the amount of state need-based financial grant aid received at public institutions, the amount of tuition and the fees per student charged to in-state students, student characteristics and academic programs?

6e. Is there a relationship between the amount of state need-based financial grant aid received at private institutions, the amount of tuition and the fees per student charged to in -state students, student characteristics and academic programs? 
6f. Does the amount of state need-based financial grant aid received by students at public institutions differ significantly from the amount of state need-based financial grant aid received by students at private institutions?

7a. Is there a relationship between the amount of federal grants, veteran, and tax benefits received per student at public institutions, the amount of tuition and fees paid per student, student characteristics, and the economic and political characteristics of the states?

7b. Is there a relationship between the amount of federal grants, veteran, and tax benefits received per student, the amount of tuition and fees paid per student, student characteristics, and the economic and political characteristics of the states?

7c. Does the amount of federal grants, veterans and tax benefits received per student at public institutions differ from the amount of federal grants, veterans and tax benefits received per student at private institutions?

8a. Is there a relationship between Tuition and fees minus all grants, veteran, and tax benefits for in-state students enrolled at public institutions and adjusted gross income?

8b. Is there a relationship between Tuition and fees minus all grants, veteran, and tax benefits for in-state students enrolled at private institutions and adjusted gross income?

8c. Does the amount of tuition and fees minus all grants, veteran, and tax benefits for in-state students at public institutions differ from the amount of tuition and fees minus all grants, veteran, and tax benefits for in-state students at private institutions?

$8 \mathrm{~d}$. Is there a relationship between Tuition and fees minus all grants, veteran, and tax benefits for out-of-state students enrolled at public institutions and adjusted gross income?

8e. Is there a relationship between Tuition and fees minus all grants, veteran, and tax benefits for out-of-state students enrolled at private institutions and adjusted gross income? 
8f. Does the amount of tuition and fees minus all grants, veteran, and tax benefits for in-state students at public institutions differ from the amount of tuition and fees minus all grants, veteran, and tax benefits for in-state students at private institutions?

\section{Significance of the Study}

Higher education financial policies regarding tuition pricing, financial aid, and state appropriations must be coordinated by state governments to deliver a maximum level of human capital for their economic growth. The results of this study may be used to:

1. Provide data regarding the efficacy of state higher education financial policies.

2. Provide data regarding the fairness of state higher education financial policies.

3. Encourage state policy makers to consider the effects their decisions have on the development of human capital.

4. Persuade state policy makers to increase the level of tuition and fees paid by affluent families.

5. Encourage state policy makers to use the additional revenues that can be collected from affluent families to increase the financial aid for low-income students.

The remaining chapters of this dissertation consist of the review of the literature, the research design and methods section, data analysis, and conclusions. 


\section{CHAPTER TWO \\ Review of Literature \\ Introduction}

To understand the economics of public higher education, its political foundations must be understood. An understanding of its intended purpose can be constructed from the history of public higher education in the United States. It is also useful to examine current policies and practices for the funding of public higher education. The economic benefits of higher education should be recognized. The first section of this chapter is a review of the research on these topics. Building on the historical foundations of American higher education, the relationships of tuition, contributions, governmental appropriations, institutional financial aid, and governmental financial aid may be understood. A theoretical framework for higher education markets is proposed in the second section of this chapter. This framework is derived from price discrimination theory found in the literature. In the final section of the chapter, the research and findings of recent studies is discussed in relation to the higher education markets theory developed in the previous section.

\section{Political Foundations of Public Education in the United States}

The initial sections of this chapter will discuss the political philosophies supporting the development of public higher education institutions. First, a brief history of public higher education in the United States and the causes for its creation and expansion are provided. The second section will address the current economic condition of public higher education and its relation to the intent of historical leaders, the economic relationships among state appropriations, tuition, financial aid, and contributions as well as economic models for the industry. 


\section{Public Education History}

Before an analysis of the financing of state colleges and universities is conducted, it is necessary to understand the purpose of public higher education. Because the funding of public colleges and universities is not entirely driven by the relationships between institutions and students, the political philosophy supporting its existence must be explored. It is useful to examine the philosophical statements made by the statesmen who promoted public higher education as well as pertinent legislation. It appears that the expansion of public higher education was driven as much by political posturing as it was by the sponsorship of philosophical ideals.

State supported higher education institutions were established shortly after the Revolutionary War. Georgia established a state supported institution of higher learning in 1785. North Carolina established a college four years later and was followed by South Carolina in 1805 and Maryland in 1807 (Addis, 2003). Through the efforts of Thomas Jefferson, the University of Virginia was founded as a public institution in 1819 (Addis, 2003). The number and size of public colleges and universities were accelerated by the enactments of land grant legislation. Public normal schools, the GI bill, and the advent of federal financial aid programs further extended the growth of public education.

The initial educational and political philosophy supporting the development of statesupported schools may be found in the writings of Thomas Jefferson. As the founder of the University of Virginia, Jefferson believed that citizens must be educated to ensure the survival of the nation. He stated:

Enlighten the people generally, and tyranny and oppressions of body and mind will vanish like evil spirits at the dawn of day....I believe it [human condition] susceptible of much improvement, and most of all, in matters of government and 
religion; and that the diffusion of knowledge among the people is to be the instrument by which it is effected." ("Jefferson Quotations," N.D.)

It appears that a primary motivation for the creation of a state-supported university was to provide a secular alternative for instruction. Jefferson believed that knowledge should be based on humanism rather than the revelations of Scripture (Addis, 2003) This view conflicted with the educational philosophies of the other existing institutions of his day. Most were affiliated with Christian denominations and even the state-supported schools often taught from a religious perspective (Addis, 2003).

According to Jefferson, the country needed a ruling aristocracy; however, that status should be merit-based rather acquired through an accident of birth (Addis, 2003). As a practical matter, it was difficult for him to gain support for the education of students from poor families. The affluent class of Virginia was not interested in paying taxes for this purpose. In addition, "the poor were oftentimes too proud to attend public schools because they viewed them as charity, or had no interest in reading, writing, and math" (Addis, 2003, p. 5). Although Jefferson promoted the idea of higher education for the citizens of the new nation, in reality, the University of Virginia educated the sons of the wealthy. The University of Virginia charged more for tuition than any other school in the country (Thelin, 2004).

In addition to the goals promoted by Jefferson ensuring that the country's citizens would have the intellectual skills necessary for self-governance, early legislation promoted higher education as an instrument to fuel economic development. In 1787, the Northwest Ordinance was passed, “...authorizing the sale of public land for support of education, thus establishing the land grant principle" ("The Land Grant Tradition: A Chronology of Federal Legislation 
Affecting Public Higher Education," N.D.). Under this legislation, Alabama, Arkansas, California, Florida, Illinois, Indiana, Iowa, Kansas, Louisiana, Minnesota, Mississippi, Ohio, Oregon and Wisconsin received grants of land to establish institutions for public education. North and South Carolina followed Virginia's lead and created state-supported institutions.

Although the missions of these institutions did not vary significantly from their private competitors, during the first half of the $19^{\text {th }}$ century, they were considered to be substandard in quality (Lucas, 2006). During this time, the demand for more relevant courses began to increase. American institutions of higher learning were being asked to expand their focus beyond the curriculum prescribed for students in law, medicine or theology (Lucas, 2006). Curriculums slowly added courses related to occupational pursuits in addition to the traditional courses in the classics (Lucas, 2006). By 1858, several states had established agricultural and mechanical schools to increase educational opportunities for more farmers and other members of the industrial class of citizens. These schools were created by Iowa, Maryland, Michigan and Pennsylvania (Edmond, 1978) .

The First Morrill Act of 1862 was the first major federal effort to promote broad economic development through public education. This legislation provided for the sale of federally owned land to fund endowments for the:

...support, and maintenance of at least one college where the leading object shall be, without excluding other scientific and classical studies and including military tactics, to teach such branches of learning as are related to agriculture and the mechanic arts, in such manner as the legislatures of the States may respectively prescribe, in order to promote the liberal and 
practical education of the industrial classes in the several pursuits and professions of life. ("The Land-Grant Tradition Morrill Act," N.D., p. 2)

Although it appears that the Morrill Act's purpose was to provide higher educational opportunities for citizens, it was foremost an expedient solution for the settlement of land owned by the federal government. If the need for a workable land policy had not existed, the land grant institutions probably would not have been established (Thelin, 2004).

Students were charged little or no tuition and fees to attend these institutions because their families could not afford the costs. This practice remained in effect until the end of the Great Depression.

The scope of the Morrill Act was expanded several times. In 1890, a second act was passed which provided funding for the creation of 18 institutions for black students. In 1916, the Secretary of the Interior ruled that "instruction in the industries for women is included in instruction in agriculture and mechanic arts" ("The Land-Grant Tradition Morrill Act," N.D., p. 5).

Several cities also founded public institutions of higher learning. The cities of Charleston, South Carolina, and Louisville, Kentucky established institutions in 1837. They were followed by New York City in 1847. Cincinnati, Toledo, and Detroit created new public institutions after the Civil War. These institutions also charged little or no tuition (Lucas, 2006).

The development of public primary and secondary school systems also influenced the growth of public higher education. To keep up with the demand for qualified teachers, normal schools were established (Thelin, 2004). In 1838, Massachusetts legislature authorized the 
creation of three state-funded normal schools. Other states followed the lead of Massachusetts and founded their own normal schools.

The typical normal school was founded in a municipality that submitted the most attractive bid. This practice encouraged local support for the colleges. Often, this support was crucial for the survival of the schools because they did not always enjoy the full support of the states' legislative bodies. The legislative bodies in several states introduced legislation to close the normal schools. Other states delayed or withheld appropriations (Ogren, 2005).

Because states wanted to ensure that local school systems would have an adequate supply of teachers, they used tuition policy to encourage graduates to remain in the state and teach. "Most state normal schools charged a modest tuition, which they waived for state residents who signed a pledge to teach in the state after graduation, usually for no more than a few years" (Ogren, 2005, p. 80).

Thomas Jefferson was not the only statesmen who saw the need for educated citizens. In the early 1900s, Governor and Senator Hiram Johnson and the University of California's President Benjamin Ide Wheeler developed plans for higher education. They wanted to give voters the intellectual tools to guard against the monopolistic practices which were conducted by the Southern Pacific Railroad and the oil companies. To accomplish this goal, attendance at the institutions had to be affordable (Thelin, 2004).

California further refined its educational system between 1900 and 1920. The state developed a system that allocated the responsibilities for education of the state's population among the institutions. The best-performing students attended the universities. The middle tier of students attended the state colleges and the community colleges were open to any student who wished to enroll(Douglass, 2000). Only the universities were allowed to issue doctoral degrees 
(Douglass, 2000). The state colleges awarded bachelor's degrees. In 1947, they were granted the right to award master's degrees (Douglass, 2000). Students paid very little to attend the system's institutions because California had adequate financial resources for their support(Douglass, 2000). The educational system was considered to be "... the key element for developing an efficient and prosperous economy" (Douglass, 2000, p. 92).

Another significant stimulus to the growth of higher education was the GI bill. Named the Service Member's Readjustment Act of 1944, it was enacted to support the returning World War II soldiers' transition from military to civilian life. Lawmakers were concerned that the returning soldiers would face high unemployment as the economy moved from wartime to peacetime production (Thelin, 2004). Returning soldiers could attend college tuition free for a maximum of 48 months. For 90 days of service, they received one year of education. In addition, they received one month of education for each month of active duty and a subsistence allowance (Thelin, 2004).

Many returning soldiers took advantage of the educational provisions of the GI Bill. By 1950, more than 16 percent of the veterans had pursued education under the legislation. Although the benefits were granted for the attendance at both public and private institutions, it appears that state - funded institutions were in the best position to finance the increases in capacities necessary to accommodate the additional students.

In 1946, President Harry Truman created the Commission on Higher Education to review higher education in the United States and produce a report recommending how institutions could best serve democracy. Truman's vision included the expansion of instruction for minorities and individuals from low-income families (Thelin, 2004). The report called for a 
general reduction in tuition costs at public institutions as well as the development of scholarship and fellowship programs (President's Commission on HigherEducation, 1947).

It is clear that commission members believed that education was critical for the development of future leaders. According to the report, graduates should “...participate actively as an informed and responsible citizen in solving the social, economic, and political problems of one's community, state, and nation" (President's Commission on HigherEducation, 1947, p. 51). In addition, a graduate of an institution should “....recognize the interdependence of the different peoples of the world and one's personal responsibility for fostering international understanding and peace" (President's Commission on Higher Education, 1947, p. 51). The members of the commission believed that students enrolled in colleges and universities should receive a balance of technical training and ... "the transmission of a common cultural heritage toward a common citizenship...” (President's Commission on Higher Education, 1947, p. 49).

The cold war contributed to the further involvement of the federal government in higher education. In 1957, the launch of the Soviet Union's spacecraft created a crisis of confidence in the United State's scientific and engineering knowledge base. As a result, the National Defense Student Loan Program was created by the National Defense Education Act of 1958 (Archibald, 2002).

In 1965, the Federal Government enacted legislation to provide significant resources for the financing of higher education. The Higher Education Act created the Title IV financial aid programs which included Educational Opportunity Grants and the Guaranteed Student Loan Program. This program subsidized the interest paid by borrowers and provided for payments to private lenders for defaulted loans. The Act also reauthorized the National Defense Education 
Act and created the work-study program. These programs were important weapons for the President Lyndon B. Johnson's War on Poverty (Archibald, 2002).

The 1972 reauthorization of the Higher Education Act resulted in the creation of the Basic Economic Opportunity Grant. It replaced the Educational Opportunity Grant. Instead of requiring institutions to determine the level of award, the calculation was made by the federal government. A State Student Incentive Grant was also initiated which required matching funds from state governments (Archibald, 2002).

Minor changes were enacted in the following decade. In 1992, unsubsidized guaranteed loans were made available to students who did not qualify for other need-based loans (Archibald, 2002). This was the first legislation designed to provide assistance for middle-income families. Further assistance for middle-income families was provided by the Hope Scholarship Credit in 1997. Eligibility for the credit was not determined by need (Archibald, 2002).

Although the founding fathers did fully define the philosophical and economic purposes of public higher education, some conclusions regarding our nation's understanding regarding the role of state and federally supported higher education can be drawn from the legislative history. For example, the existence of public institutions with secular curricula was important. Thomas Jefferson's concept of institutions that did not have a Scriptural base has been a model for other public colleges and universities.

It appears that World War II had a strong influence on the recommendations of the President's Commission on Higher Education. The Commission recognized the need to develop graduates who could participate effectively in a global society.

It is clear that lawmakers believed in the power of higher learning to provide economic benefits to college graduates. By charging little or no tuition, they demonstrated their beliefs that 
education should be affordable and available to the industrial class. Although the Morrill Act may be viewed primarily as a land-use policy, it is evident that its proponents understood that economic benefits would accrue from its passage. The importance of public higher education as an economic development tool was further underscored by the passage of the GI Bill. Low tuition and fee charges were also promoted by the President's Commission on Higher Education.

State funding of higher education was also provided to advance other governmental interests. Normal schools were founded to support the state-supported efforts to provide mandatory, free education for children.

Additional reasons for the creation or continued support of colleges and universities may exist. For example, lawmakers may have established an institution in an economically depressed area to stimulate the local economy. They may also be reluctant to close marginally performing institutions for the same reason. Public institutions may have been founded in areas that could not support a privately-funded school.

Although it appears that lawmakers supported the concept of low or no tuition, it is not clear that a philosophy of political economics was used as a basis for this position. For example, it appears that land-grant institutions charged little or no tuition to attract students from the industrial class. There does not appear to be any concern that higher income families would also attend these institutions and pay below market tuition prices. Moreover, there does not appear to be any evidence that state normal schools discriminated among families from various income levels in their tuition policies.

Until income tax legislation was enacted in 1913, there was no formal reporting structure of income (United States Department of the Treasury, N.D). A presumption that all students 
attending these institutions could not afford to pay tuition could not have been based on sufficient data to support such a conclusion.

The President's Commission on Higher Education did not address this issue through tuition prices. It did, however, advocate for the development of federal financial aid to support students enrolled in colleges and universities (Education, 1947).

The lack of concern that students from higher income families would receive an unwarranted benefit from low tuition charges may not have been an oversight. It is possible that the desire to attract students with strong academic credentials offsets the need to increase revenues from students from higher income families. It appears that not until recent years, did lawmakers consider the option of using revenues from more affluent families to provide scholarship assistance for students from low-income families.

Little information is available regarding the historical enrollment distributions of students by income level. Perhaps the overwhelming majority of students from higher income families attended private institutions and students from low-income families attended public schools. Policy makers may have believed that they understood the income distribution of students and therefore, did not perceive the need for data. On behalf of the National Center of Education Statistics, the Census bureau has performed an annual survey in recent years. The survey collects family income data for students enrolled in college (Kane, 1999).

The view that students from affluent families would not typically attend public institutions does not appear to contradict the intent of lawmakers who supported the growth of public higher education. Thomas Jefferson did not support low tuition charges for the affluent students who enrolled at the University of Virginia. It may not have been the original intent of Congress to provide state support for the education of students from affluent families. Although 
low-income families were the primary source of students attending the land-grant institutions

during the $19^{\text {th }}$ century, it is likely that modern enrollments exhibit a mixture of income levels.

On the other hand, it is likely that Congress understood that a portion of the soldiers returning after service in World War II were from affluent families. The GI Bill had no restrictions on income levels of its beneficiaries.

The idea of targeting a group by making the benefits of legislation available to all citizens may be the current justification for low levels of tuition. This philosophy was used to promote Social Security. By making retirement and disability benefits available to all citizens, the task of gathering support was simplified. Without the support of the wealthy, the legislation may not have passed (Archibald \& Feldman, 2006).

From this historical review, it appears that legislation and governmental resources have been directed primarily towards the development of human capital. The Land Grant legislation, GI Bill and federal financial involvement in higher education stem from the desire to promote economic growth directly through vocational training or indirectly through the training of teachers. It is recognized that teacher education is a vocation; however, it appears that the primary purpose of the normal schools was to supply teachers for public schools. These schools, in turn, were an important tool in the development of human capital.

\section{Current Practices in Public Higher Education Finance}

From a historical perspective, most public higher education institutions were founded to educate students who could not generally afford to attend private schools. Until recently, governmental financial support was almost exclusively designed to assist lower-income students. It appears that education was viewed as a means for economic development. The 
development of an educated populace that was able to participate effectively in representative government was also valued.

Although many states appear to adhere to the historical intent of public higher education, other states have deviated significantly from the original purpose. In a survey conducted by the State Higher Education Executive Officers in fiscal year 2006, only 26 states responded that they supported specific tuition levels. Of these states, 16 believed that tuition should be as low as possible, eight promoted moderate levels of tuition, and two supported high tuition. Alabama, Delaware, Michigan, New Jersey, New Mexico, North Dakota, Ohio, Pennsylvania and Washington did not have a formal tuition policy at the state level. Only Michigan believed that markets should determine tuition rates. "The belief that low tuition will help to increase (or at least maintain) current levels of participation was shared by 18 states" (Boatman \& L'Orange, 2006, p. 7).

State appropriations are the most common factor contemplated by states in the process to set tuition rates. The prior year's tuition, institutional mission and the tuition charged by peer institutions are also important considerations. The public and media concerns regarding affordability, other student fees and charges, and the cost of instruction also influence the decision process (Boatman \& L'Orange, 2006).

As mentioned previously, states have established reciprocity agreements to allow nonresident student to pay less than the standard amount of tuition. These students must have certain characteristics such as the proximity of their residency to a states' border. In 14 states, non-residents students who live within 50 miles of the border of a state pay in-state rates. A student exchange program exists among ten states, allowing students to attend a public institution in a participating state at in-state rates. Students who enroll in programs that are not available in 
their home state may pay a rate equal to $150 \%$ of the in-state rate in Maine, Nebraska, New Hampshire, Massachusetts, and Rhode Island. Some institutions have specific exchange agreements with other institutions in Maryland, Massachusetts, Missouri, South Carolina, and Utah (Boatman \& L'Orange, 2006).

States have addressed affordability issues in several ways. The surveyors found that most states assign the role of low-cost institutions to their community colleges. Indiana requires institutions to set their tuition rate for two years at a time. Other states have imposed tuition caps. Tuition caps range from $3 \%$ to $10 \%$ for the eighteen states that impose a limit. New Mexico and Montana have considered using revenues from tuition increases to fund need-based financial aid. Incoming first-year students at Illinois' colleges and universities pay the same tuition amount for four years. Some states provide loan forgiveness programs if graduates remain and work within a state for a certain period of time.

Many states reduced operating costs to improve affordability. Freezes on hiring and filling positions, delays in deferred maintenance and the elimination of programs were the most common strategies used to cut costs (Boatman \& L'Orange, 2006). By decreasing costs, institutions may reduce the level of tuition and fee increases.

A wide variety of strategies were used for the setting of non-resident tuition and fee rates at state institutions. "California, Massachusetts, Rhode Island, and West Virginia charge 100\% of the cost of instruction" (Boatman \& L'Orange, 2006, p. 17). Non-resident students in other states are required to pay certain percentage of the cost of undergraduate tuition. Nine states index the non-resident tuition rates to resident rates. These programs appear to be most common in healthcare fields. 
Affordability was also addressed by states through their financial aid policies. Of the states in the survey, 35 maintained goals to promote broad access to higher education. It was also important for some states to improve the affordability of higher education, keep talented students within the state, promote student retention, and recognize talent. Wisconsin and Maryland are shifting merit-based aid funds to need-based programs. New Jersey, Tennessee, and South Dakota have recently created new need-based programs. Of the states in the survey, 46 offer need-based grants and 34 offer statewide merit-based scholarships.

Some states have defined the relationship between financial aid and tuition and fees. The flagship institutions of Indiana, Nevada, the University of New Hampshire System, New Jersey Ohio, Pennsylvania and South Carolina use a high tuition/ high financial aid policy. Idaho and Kansas have low tuition/low financial aid philosophies. Maryland's policy is to charge high tuition and provide moderate financial aid. Moderate-to-low fees coupled with moderate-to-high financial aid characterize California's policy. Arizona maintains a moderate tuition and financial aid policy (Boatman \& L'Orange, 2006).

The Southern Regional Education Board ("The SREB”) has tracked higher education state appropriations as a percentage of total state taxes paid from fiscal year 1962-63 through fiscal year 2004-05. In the first year, state appropriations for public colleges and universities equaled $8.6 \%$ of the total state taxes paid. The percentage rose to $14.2 \%$ in fiscal years $1975-76$ and 1982-83. By fiscal year 2004-05, state had reduced their appropriations to $9.7 \%$ of taxes. 
Figure 1: State appropriations as a percentage of total taxes

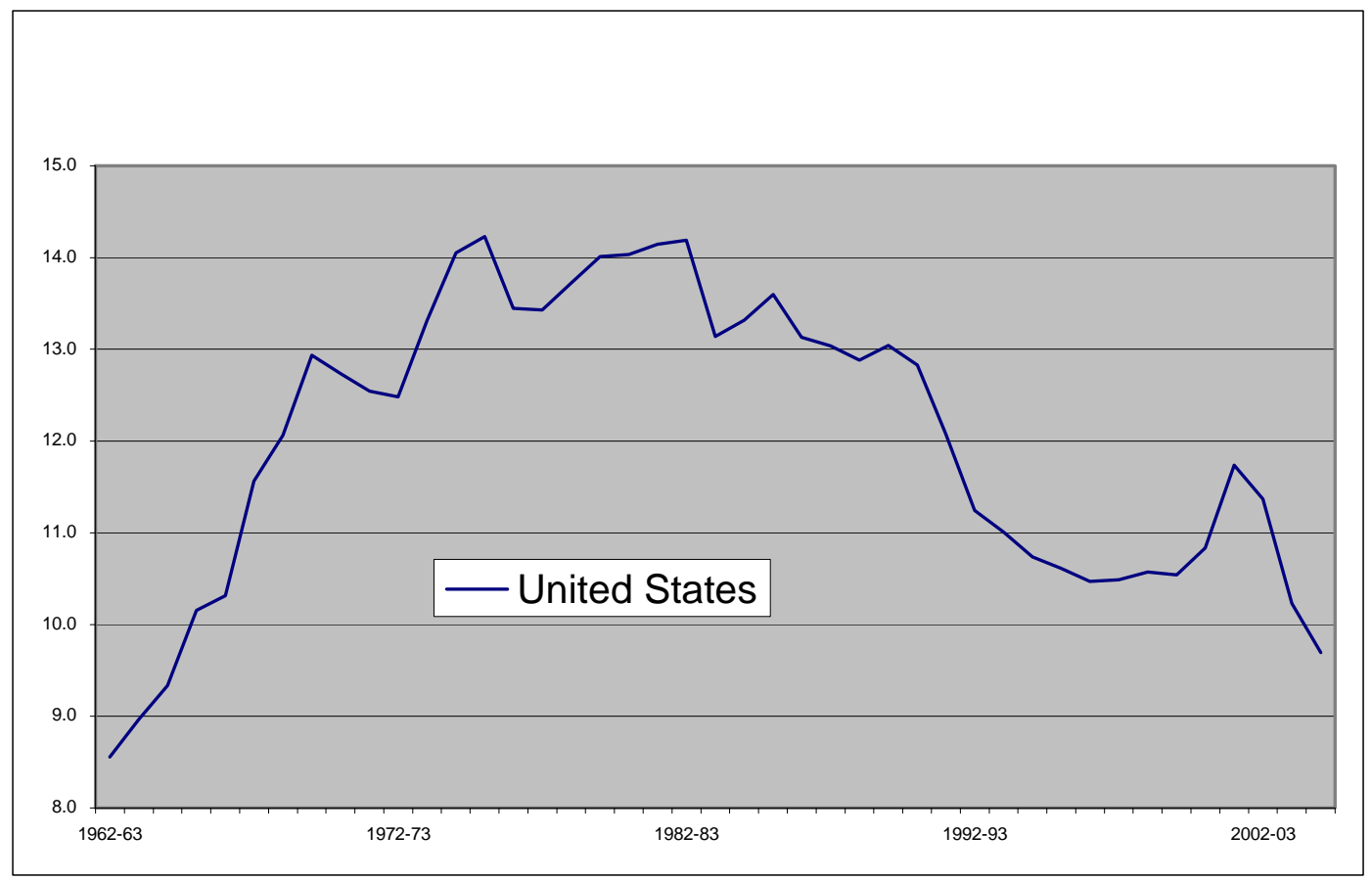

Source: ("Percent Distribution of State and Local Government General Expenditures," 2006)

The SREB has also maintained statistics for the percentage of state per capita income devoted to higher education appropriations. From fiscal year 1982-83, states have maintained appropriations within a range from $8.4 \%$ to $9.5 \%$. The percentage was highest in fiscal year 1982-83. It declined to $8.4 \%$ from fiscal year 1993-94 through fiscal year 1995-96. The percentage of per capita income that state appropriated to higher education institutions in fiscal year 2005 was 9.1\% (The Investment Payoff, A 50-State Analysis of the Public and Private Benefits of Higher Education, 2005). 
According to data provided by the SREB for fiscal year 2004-05, the median tuition charged by public four-year colleges was $\$ 4,579$ and the median household income for 2004 was $\$ 44,334$. The tuition price charged to the typical household in that year was $10.33 \%$ of the household's income. This percentage has risen considerably since fiscal year 1992-93 when the median tuition price charged was $\$ 2,076$ and the median household income was $\$ 30,636$. The resulting percentage of household income that a typical family was charged before reductions for financial aid was 6.77\%. ("Percent of Median Family Incomes Required to Pay Median Annual Tuition and Fees," 2006).

Although the decline in state funding is troubling, changes in the sources of tax revenues supporting higher education have also raised concerns. According to Bowden and Elrod (2004), 18 of the 39 states operating lotteries in 2004 dedicated revenues to higher education. Because low income and minority individuals are most likely to play state lotteries, the revenues collected represent a regressive tax. It may be argued that the revenues are not taxes because they are paid voluntarily. This argument may not be valid because other revenues such as sales taxes are also willingly paid. They cite Georgia as an example of a state that uses lottery proceeds to fund its merit scholarship program (Bowden \& Elrod, 2004).

States appear to be funding the higher education of their more affluent families at the expense of poorer families. It is more likely for children from more affluent families than poor families to attend public institutions. Given the regressive nature of the lottery revenues, the poor are providing a disproportionate share of resources to the programs such as higher education that are funded by the lotteries (Bowden \& Elrod, 2004).

\section{The Economic Benefits of Higher Education}


To understand the economic value of higher education, it is important to examine the effect a degree has on a graduate's lifetime income potential. The Big Payoff: Educational Attainment and Synthetic Estimates of Work-Life Estimates of Work-Life Earnings, a report issued by the U.S. Census Bureau in 2002, demonstrates the economic value of higher education. According to the report, the ratio of the differences between income levels of individuals with at least bachelor's degrees and individuals with only high school diplomas had risen from 1.5 to 1.8. As technological advances are made, the need for a higher education diploma becomes more critical. The income levels of workers without bachelor's degrees have declined while the income levels of workers with degrees have increased (Day \& Newburger, 2002).

An educated populace provides economic benefits to society as a whole, including “...increased tax revenues, greater productivity, increased consumption, increased workforce flexibility and decreased reliance on government financial support, a more flexible workforce, a more informed democracy, less crime, more care for the environment, and a higher level of public health" (The Investment Payoff, A 50-State Analysis of the Public and Private Benefits of Higher Education, 2005, p. 4).

Given the obvious economic benefits of higher education, one would expect individuals to borrow funds for their children's enrollment in institutions of higher learning. This has not been possible without governmental support because private capital markets have been historically reluctant to finance investments in human capital. No collateral exists to protect the lender in case of default.

Borrowing to finance higher education is also risky for families. It is not certain that their children will be successful in college. About one-half of the students who enroll in college obtain 
degrees. Even if they do graduate, they may have chosen a field of study for which a job market does not exist (Garratt \& Marshall, 1995).

Attendance rates by low-income families may involve more factors than price sensitivities. Although financial aid has been made available to low-income families, their rates of attendance at institution of higher learning are still low. The low attendance rates may be attributable to the intricacies of financial aid policies (Courant et al., 2006). These individuals may also be more risk averse regarding the investment of time and money into the educational process. The opportunity costs associated with foregone earnings from employment may play a more significant role in the considerations of low-income individuals.

It appears that the complexities of the application processes for higher education and financial aid discourage low-income students from attendance. In a study conducted by Avery and Kane, "more than 65 percent of the Boston public school students... reported at the start of their senior year in high school that they planned to attend a four-year college immediately after graduation, but less than 25 percent of them actually did so" (Avery \& Kane, 2004, p. 356).

Because of the difficulties encountered in price analysis and the measurement of the product quality, it is useful for governmental agencies to assume a substantial portion of the risks associated with the human capital investments associated with higher education. If the human capital investment results in higher income levels for a state's citizens, collections of tax revenues would increase. A state could also reduce its subsidies of higher education if the income levels increase enough to enable families to afford a higher tuition level. The reduced support of higher education could result in lower taxes.

Although the economic risks to individuals and the capital markets may be overwhelming, the states have been willing to assume investment risks. The existence of 
governmental investments in higher education makes it difficult to use economic price theories to analyze the interaction of the consumer and the market.

\section{Summary}

Because the investment risk in human capital is high, state, federal, and local governments have been willing to fund higher education. Efforts have been made to fund the development of skills in certain areas such as agricultural, engineering, and secondary education. Although states have tried to keep the costs of postsecondary education affordable, the support for low tuition is mixed. Financial aid is awarded to low-income students and students with good academic skills.

As a percentage of taxes, state appropriations funding has declined from its peak in fiscal years 1975 and 1976. As a result, the burden placed on students and their parents to pay for their education has increased.

The extent that public higher education has remained true to its original purpose of human capital development is not clear. Majors are not limited to programs that can spur economic development such as engineering or contribute to the public good such as education. Furthermore, the students who attend public institutions come from families with a broad range of incomes.

\section{Theory of Higher Education Markets}

Many authors have concluded that the relationship between tuition and financial aid is principally the result of price discrimination by colleges and universities. The part of this section 
will discuss the concept of price discrimination. The conditions that exist for price discrimination are described in the second section. A theory of higher education markets is developed in the third section. This theory is used to examine price discrimination as it relates to higher education markets in the fourth section. The fifth section describes pertinent tax laws in relation to price discrimination. The sixth and final section examines the relationships among the higher education markets.

\section{Price Discrimination}

In addition to the existence of governmental funding, other reductions to the price of attendance in higher education contribute to pricing analysis difficulties. In some cases, these reductions constitute price discrimination. Price discrimination may be defined as "... a situation where a firm charges different prices (relative to marginal costs) to different customers for the same product” (Lawson \& Zerkle, 2006, p. 1). Firms may price discriminate by charging customers different prices or charging the same price for the same product with different costs. An example of the latter is the practice of some firms to charge the same price regardless of differing shipping costs (Carroll \& Coates, 2001).

In order to effectively price discriminate, three conditions must exist. First, firms must have some market power to raise or lower the price to some customers. In addition, it must not be possible for consumers to resell the product to others. Finally, customers must have different price elasticities of demand (Carroll \& Coates, 2001).

Economists have segregated the extent of a firm's ability to price discriminate into three levels. The level to which a firm can efficiently engage in price discrimination is dependent upon the amount of information it has regarding its customers. A firm may engage in first degree price 
discrimination if it has perfect knowledge of each customer's demand elasticity. For example, an automobile salesperson may acquire much information about customers and offer them different prices. An example of a second-degree price discrimination practice is the offering of volume discounts. Although the firms do not have knowledge of each customer's characteristics, they permit buyers to self select into groups. This self-selection process reveals information about the consumers. Finally, firms engage in third-degree price discrimination by separating customers into groups. An example of third-degree price discrimination is the practice of granting seniorcitizen discounts.

\section{Conditions for Price Discrimination in Higher Education}

Although the existence of multiple markets within higher education creates some ambiguity, it appears that colleges and universities engage in price discrimination. Schools have some market power to raise or lower tuition prices to some customers. Because colleges and universities receive substantial gifts from individuals and corporations, they can use these resources to award scholarships to students with specific characteristics. The ability to charge less than the full cost of attendance allows institutions to “... restrict entry to the industry, reduce in some dimensions the diversity of the products that are produced, and perpetuate misallocations of resources among the 'firms' comprising the higher education sector" (Nerlove, 2001, p. S181). The higher education industry restricts entry into the market through the accreditations of institutions and individual programs.

The second condition for price discrimination mentioned above is also met by colleges and universities. The output of colleges and universities may be defined as human capital. The 
human capital represented by course credits and degrees cannot be resold to other students.

Students may not resell their enrollment acceptances to other students (Lawson \& Zerkle, 2006).

Students have different elasticities of demand depending upon their level of income and their academic abilities. This circumstance satisfies the third condition for price discrimination.

\section{Higher Education Markets}

It is difficult to estimate the elasticity of demand for college students for several reasons. Institutions of higher learning receive revenues from multiple sources. Revenues from tuition and fees, endowment contributions, state appropriations, and governmental financial aid are used to fund instructional expenses. Federal, state and private entities provide grants for research. In addition to these resources, students contribute to the education process through their participation.

It is useful to view each of these resources as separate markets. Markets exist for educational services, the value received by donors for their contributions and the value received by governments for economic development. Governments may pay for economic development by providing appropriations to schools. They may also provide financial aid to students without regard to which accredited institution they attend. In the Instructional Services market, students pay tuition and fees for the right to receive these services.

Another market consists of high-performing students. Colleges and universities are the consumers in this market for high-quality students. They pay for the participation of these students by discounting their tuition and fees.

Entering students with strong academic credentials enhance the quality of a college or university's output for other students. By increasing the number of high-performing students, 
institutions can increase productivity. Expenditures of resources on these individuals should yield a better than average output per dollar spent (Rothschild \& White, 1995). Because the end product of higher education is influenced to a great extent by the efforts and abilities of the consumer, the quality of the credits and degrees awarded at a given institution will depend upon the attributes of its students.

Colleges and universities may benefit economically from the practice of charging high performing students discounted prices for tuition (Nerlove, 2001). These students can demand lower prices as institutions compete for their applications (Lawson \& Zerkle, 2006).

Some authors consider the tuition discounts to be the equivalent of wages paid to high performing students for their contributions to the institutions (Rothschild \& White, 1995). Because stronger students typically spend more time on their studies and contribute to the learning of other students, their economic contribution is probably greater than low-performing students. If the contributions of higher performing students are considered in the equation, tuition discounts may simply offset the economic value reflected by their contribution.

It may be useful to compare a high-performing college student to a person whose belongings are being moved to a new house. In this situation, the moving company cannot find enough helpers to unload the moving van. The new owner of the house, wanting to get his furniture inside the house, offers to help the driver unload his belongings. He agrees to help the driver, but he insists that the value of his labor be deducted from the moving bill. The discount offered to the owner does not constitute price discrimination to the extent that it reflects at least the market rate for his labor contribution. In the same way, students' contributions to the educational process should be considered in the analysis of price discrimination in higher education. 
In addition to academic abilities, students often receive discounts for other contributions such as the participation in intercollegiate athletics or marching bands. It also may not be correct to view these discounts as price discrimination.

Another market consists of contributions made to institutions. In this market, colleges and universities sell the perceived quality of the institution and the opportunity for donors to make significant philanthropic contributions. Institutions of higher learning tailor their opportunities to the desires of the donors.

Donors provide money to institutions to help targeted groups of students attend college. The institution must use these funds as directed by donors. Endowments are established to pay tuition for athletes, lower-income students, students in certain majors and many other purposes. The decision to use these funds does not depend upon the current economic analysis of the institution's financial position or the higher education market. Prior to the establishment of an endowment, an institution may have some influence over the purpose designation; however, it cannot change this designation after the endowment has been created. It is possible that scholarships are awarded to students who would have paid full price to attend an institution regardless of a scholarship awarded from a given endowment fund.

Some colleges and universities may use the Instructional Services market to enhance revenues in the donor market. Children of wealthy alumni are often granted admission to an institution at a higher rate than students in the general population (Vedder, 2004).

The markets for state appropriations and federal revenues are somewhat similar to the market for donations. Colleges and universities that are eligible for state appropriations provide secular and affordable education for the citizens targeted by the government. In return for funding, schools must submit to governmental control and oversight. The market consists of 
producers of human capital for economic development as well as educated citizens who are capable of participating in democratic processes.

Students are ultimately the sellers in the market for governmental financial aid. The federal or state governmental agency is the consumer paying to attract students with certain characteristics. Funds are often expended for the education of low and middle income students. Some governmental funds are expended to attract high-performing students to particular institutions. The intentions of these agencies typically are to spark economic development and reduce poverty levels. Colleges and universities broker the funds to convert the inputs of lowincome students into human capital.

Governmental appropriations and need-based financial aid from external sources reduce the prices students pay for tuition. To determine if this reduction represents price discrimination, it may be helpful to consider again the new home owner example. Suppose the new house owner is a victim of a hurricane. A local church and the government pay the moving company directly for a portion of the moving expenses. The reduction in the net costs to the new house owner would not constitute price discrimination. In the same way, the reduction of net tuition by contributions from external sources such as donors and governmental entities is not price discrimination.

If tuition and fees were the only source of revenue for institutions, it would be relatively easy to study price discrimination in the industry. Because other markets exist, it is important to distinguish their characteristics. The price discrimination that exists in each market must be evaluated. The assertion that price discrimination exists should only be made if the practice does not reflect a wage pertaining to another market or if the needs of external entities are not the purpose of the differential. 


\section{Price Discrimination in relation to Higher Education Markets}

It may be appealing to assert that colleges and universities engage in first-degree price discrimination because much is known regarding students levels of income, academic abilities and talents. On the other hand, detailed financial data are typically available only from students who apply for financial aid. Colleges and universities do not know the family incomes of students who do not apply for financial aid.

Furthermore, it may be difficult to assert that colleges and universities engage in firstdegree price discrimination because they award many scholarships from endowments. These endowments represent the needs of donors who are external to the current management of the college or university. A scholarship endowment established 50 years ago may not reflect the current needs of an institution or its students. The donor did not have perfect information regarding the future students who would benefit from the contribution. The institution can only use the endowment earnings for the purpose stipulated by the donor. It does not have the ability to withhold awards from qualified students if the revenues from earnings are available. The donor may or may not have provided sufficient funds to adequately fund the needs of the targeted recipients.

The practice of providing state and federal aid to students may appear to represent thirddegree price discrimination. These financial aid awards are typically based on income levels of students. Institutions do not give these need-based awards for other characteristics that may have economic benefits for the institutions. On the other hand, decisions of the federal government regarding the level of financial aid are not made with consideration of individual institutions' tuition and fee levels. The awards are usually made to satisfy the economic stimulating activities 
of the governmental entity. It is probable that most of the students would be charged a higher tuition rate if the governmental grants were not available. If the institutions are determined to be the providers of economic development to the government, the pertinent market activity is between these two groups. Price discrimination may not exist because governments may be paying schools for the value of economic development. It would be reasonable for a government to pay a higher rate for lower income students because the potential return on the investment to the government should be higher.

Colleges and universities may provide need-based financial aid simply to fulfill their role as charities (Winston, 2003). They may also have a desire to produce diversity within the student body. In these circumstances, the discount may represent an economic wage to these students and not price discrimination.

State colleges and universities often charge reduced non-resident fees or in-state fees for students who live within a certain distance of the states' borders (Boatman \& L'Orange, 2006). This may represent third degree price discrimination because the institutions have adjusted the cost of attendance for a group of students with certain characteristics. On the other hand, a state may engage in reciprocity agreements to provide a critical mass of students for specific programs. Because students provide an economic stimulus to the local economy, a state may wish to reduce the price for non-resident students to boost the local economy.

It appears that there is significant evidence that colleges and universities charge differential prices for students with strong academic credentials as well as low-income and minority students (Lawson \& Zerkle, 2006). The market to attract students with certain characteristics and the markets to provide governmental funds to students with certain characteristics seem to have the most influence on financial aid. 
As noted above, price discrimination exists if individuals are charged different prices for the same product. It may be argued that each student receives a different product from a college or university. It is difficult to determine the economic benefits of the credits and degrees produced through the educational process. The economic value of a degree in fine arts or English is not the same as a degree in medicine or engineering. Moreover, students may not have the abilities or interest to take advantage of the instruction provided by institutions of higher learning. The risk associated with the investment in higher education is increased by these uncertainties (Nerlove, 2001).

Although it appears that some price differentials do not fit the model of price discrimination, some practices do appear to constitute price discrimination. The economic features of higher education pricing noted above may apply best to highly selective institutions or well-funded public schools. These institutions may be in the best position to charge the stated rate of tuition unless they are purchasing certain student characteristics or providing economic value to donors and governmental entities. Less selective institutions or poorly funded state colleges and universities may have to price discriminate to maintain enrollments. Some institutions give employers special tuition rates to teach groups of employees. Other institutions charge students enrolled in off-campus executive MBA programs more than regular, on-campus MBA students. Some colleges and universities guarantee incoming freshmen the same price throughout their enrollment at the institution. This practice results in different prices for different groups of students. These circumstances appear to be examples of third-degree price discrimination (Vedder, 2004).

According to Doti, the selectivity of an institution has an influence on its ability to charge different prices. He found that non-selective schools were unable to vary their prices to the 
degree that selective institutions could. “... Net tuition fees (tuition fees less grants) increased more rapidly for selective schools (49.4 percent versus 37.4 percent) even though their tuition rate increased more rapidly" (Doti, 2004, pp. 366-367). Less-selective institutions may not have the endowment income to award scholarships to high-performing students. Moreover, high performing students may not be attracted to less-selective institutions. The elasticity of demand is less for non-selective institutions compared to selective institutions.

As institutions have become more competitive, elasticity has declined (Doti, 2004). If the dependency on tuition at public institution increases, they will need to become more competitive. The competition in higher education may increase substantially and decrease the elasticity of demand for much of the industry. The decrease in elasticity may have a negative effect on the ability of colleges and universities to charge different prices.

The difference between the tuition price and net tuition decreased at a higher rate for non-selective colleges and universities from 1992 to 2002. As a percentage of the total at nonselective institutions, a greater percentage of students received financial aid. This change may reflect an increase in price discrimination (Doti, 2004).

Although it may be demonstrated that price discrimination exists in higher education, the timing of decisions to reduce prices appears to be somewhat restricted. It appears that schools do not practice price discrimination by reacting immediately to market conditions with price reductions. They do not reduce tuition and fees for applying students if it begins to appear that slots will be left open. Because students typically decided to enroll months in advance, this tactic is probably not useful (Vedder, 2004).

\section{Tax Laws and Price Discrimination}


Tax credits also reduce the cost of higher education. The federal government offers the Hope Scholarship tax credit and 18 states also allow tax credits for higher education payments (Boatman \& L'Orange, 2006). The Hope Scholarship tax credit was enacted as part of the Taxpayer Relief Act of 1997 effectively reduces the cost of attendance at institutions of higher learning. Taxpayers may receive a full credit for the first $\$ 1,000$ paid for tuition and other fees. For tuition and fees in excess of $\$ 1,000$ but not exceeding $\$ 2,000$, a 50 percent credit is available. The maximum credit is therefore $\$ 1,500$ and may only be taken in the first two years of attendance at a qualified institution. Students, parents, spouses of students can claim the credit. For single taxpayers with incomes in excess of $\$ 40,000$ and joint filers with incomes in excess of $\$ 80,000$, the tax credit is phased out. No credit is available for single taxpayers with incomes in excess of $\$ 50,000$ and joint filers with incomes in excess of $\$ 100,000$ (Wolanin, 2001).

Tax credits do not address the financial needs of many low-income students. Because the Hope Scholarship Credit cannot be refunded, taxpayers must have an income tax liability to take advantage of the credit. Many low-income families may not be able to take advantage of the credit for this reason. Furthermore, grants and scholarships reduce the amount of tuition and fees that may be used to calculate a credit. Costs other than tuition and fees, such as room and board and books, are not considered (Wolanin, 2001). Tax credits and unsubsidized loans reflect the addition of assistance for middle-income families to aid for low-income students.

Although the application of the Hope Scholarship results in the reduction of educational costs for the middle-income group of students, it may be difficult to assert that it reflects price discrimination. Few states have considered raising tuition to take advantage of the tax credits (Boatman \& L'Orange, 2006). The tax credit was created by the federal government and the 
institutions had no control over the provisions of the Tax Relief Act of 1997. In addition, the credit may be used to attend any qualified institution regardless of the price of attendance. If a student pays tuition in January for the spring semester of an academic year, the taxpayer may not claim the credit until the following year. It may be difficult for taxpayers to gauge the effect of the credit because it is not received at the time of enrollment.

Congress has passed other laws to promote higher education. Section 529 of the Internal Revenue Code further reduces the effective cost of higher education. It allows taxpayers to establish a saving/investment plan or a prepaid tuition account. Usually the savings/investment plans may be used by non-residents of a state. Prepaid tuition accounts are for residents. Earnings from these plans are not subject to income tax if the accounts are used for qualified higher education expenses ("College Savings Plan Network," N.D.).

\section{Relationships among Markets}

Changes in a market within which an institution operates may affect its activities in other markets. For example, a public institution may increase tuition and fees in response to reduced state appropriations. It may also commit additional resources for fund-raising efforts. Colleges and universities may increase tuition and offer more scholarships to students with attractive attributes.

The development in recent years of government-financed merit financial aid may have resulted in a misalignment of markets. State governments have provided resources to help schools enroll students with certain characteristics. The awards of merit-based aid by governments represent an entry into the market for students with certain characteristics. Without an economic development purpose, it may be difficult to justify these awards. Some argue that it 
may help a state develop economically if these students attend an in-state institution rather than leave the state. On the other hand, there is little evidence that students remain as residents after graduation.

\section{Summary}

Because higher education entails the interaction of multiple markets, price reductions may not always constitute price discrimination. In many circumstances, reductions may reflect the contribution of providers from other markets rather than price discrimination. As shown in Figure 2, the higher education economic resources flow in several directions. On the other hand, it appears that less-selective institutions engage in price discrimination practices to boost enrollments. These reductions appear to be primarily third-degree price discrimination because they are targeted at specific groups.

The market theory developed in this chapter will inform the development of econometric models for each market. These models will be used to describe the economic activities in the higher education markets. 
Figure 2: Resources flows in higher education markets

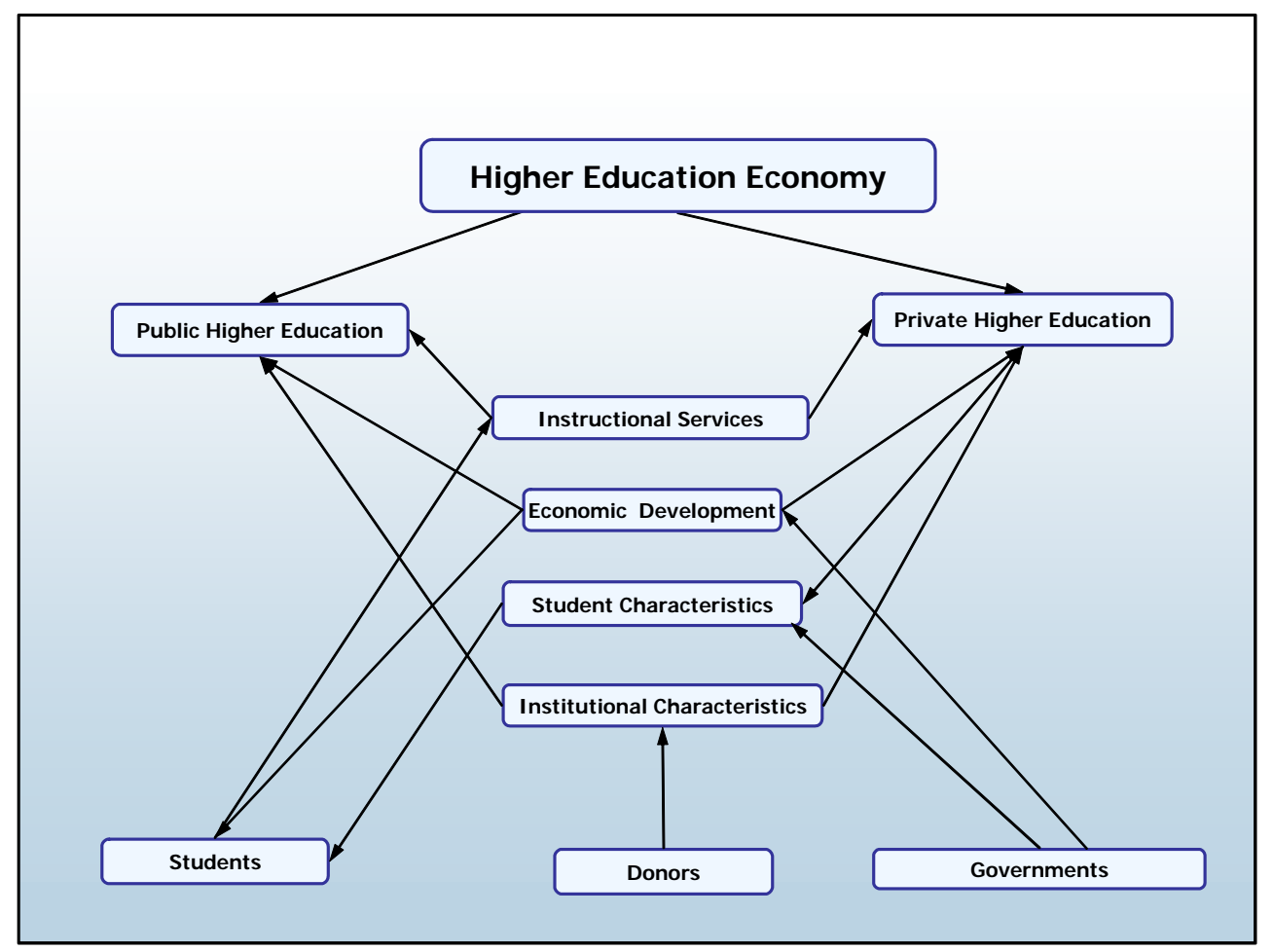

\section{Research of the Determinants of Higher Education Markets}

The purpose of this section is to review studies that examine the determinants of higher education markets. Research was examined to discover determinants that can best reflect activities in the higher education economy. In addition, determinants which provided a link to the historical purposes of higher education were sought.

It appears that studies of the determinants of higher education revenues and expenditure sources have not utilized a defined system of markets. Without a structured market theory, relationships may be defined, but they may not adequately represent higher education economic flows. Economic flows within higher education markets are a result of the characteristics of buyers and sellers. The buyers will select from a group of sellers. Because the buyers choose, the aggregate characteristics of the sellers are more important to the flow of economic resources than the characteristics of the individual buyers. Instead of defining the seller's characteristics 
that influence buyers to transfer economic resources, it appears that many of the researchers attempted to define the influential characteristics of both parties. It is difficult to define the directional flow of resources from the buyer to the seller in many studies. Although this shortcoming is found in the reviewed studies, the research provided useful information regarding the characteristics of the higher education economy.

The initial parts of this section review previous empirical studies utilizing econometric models related to tuition, donations, student characteristics, and institutional financial aid, governmental appropriations, and student characteristics, and governmental financial aid. In addition, research of the relationship between governmental subsidies of higher education and the income of students' families is examined. The final part of this section describes the limitations of the studies included in the literature review.

Although the studies examined did not assume the existence of multiple markets, the literature review is organized by the markets associated with higher education. The criterion for the assignment of a research article to a market was its usefulness in the construction of the econometric equation for that particular market.

\section{Instructional Services Market}

The studies included in this category principally examined the pricing economics of tuition. Although financial aid was considered in each study, it was not a central focus of the research. The studies utilized information from national databases.

Tuition discounting was a prime focus of literature related to tuition prices. It appears that researchers assume that the primary purpose of discounting was to maximize revenues for the university. Tiffany and Ankrom believed that colleges engage in first-degree price discrimination 
through the awarding of institutional financial aid. Because the institutions have knowledge of families' financial status, the authors believed that institutions can practice first degree pricediscrimination (Tiffany \& Ankrom, 1998). They asserted that the trend for colleges to “... increasing tuition ("sticker price") institutional financial aid, net revenue, and enrollment, is the result of colleges using price discrimination to a greater degree and better effect than in the past" (Tiffany \& Ankrom, 1998, p. 99).

The study included 233 institutions from survey data compiled by the National Association of College and University Business Officers. The authors grouped the institutions by larger research institutions, institutions offering some graduate degrees and small liberal arts colleges without graduate programs (Tiffany \& Ankrom, 1998).

Tiffany and Ankrom developed a model to explain the relationship between two dependent variables, net revenues and enrollment, and the independent variables tuition price, endowments, the number of students who paid full price, and institutional grants per student. Net revenue was defined as tuition revenue minus institutional financial aid grants (Tiffany \& Ankrom, 1998).

The authors found that “... a $\$ 1,000$ increase in [tuition] leads to a statistically significant increase in both net revenue and an increase in enrollment..." (Tiffany \& Ankrom, 1998, p. 107). They also determined that endowments have a positive but slight effect on net prices and enrollment. Larger research institutions experienced higher enrollments and net revenue as a result of higher tuition prices than the other groups. They concluded that colleges have used price discrimination to increase both enrollments and net revenues.

Tiffany and Ankrom's model did not account for differences between tuition prices for public and private schools. Because they are subject to the control and oversight of state 
governments, public institutions cannot typically set tuition prices to maximize revenues. An econometric model without a determinant for this phenomenon would not represent all of the factors that influence tuition prices for public schools. Lowry (2001) hypothesized that the tuition prices set by public colleges and universities was a function of their governance structures. He used data from IPEDS for 1995, the U.S. News and World Report and the Education Commission of the States for his study. Lowry's model assumed that gross tuition and fee revenues minus financial aid are a function of enrollments, certain qualitative aspects of the campuses, state and local government funding, state economic and demographic factors, and governing board structures. State economic and demographic factors include the local cost of living, per capita income and the percentage of 18 -year olds beginning college in the fall. The governing structure information includes the number of state legislative staff per member. The existence of a state governing board, the number of governing boards in each state, the number of campuses governed by each board, and the percentage of trustees selected by stakeholders external to the institution. The qualitative traits of institutions included their land grant status, academic reputation and whether the institutions had law or medical schools (Lowry, 2001).

Lowry identified several problems encountered in the study regarding the independence of the variables. Because the decisions by single governing boards to establish prices at multiple institutions are not likely to be independent, he performed a three-stage least squares analysis of the data. The author also was concerned “... whether governmental structure and trustee selection methods are truly exogenous, or whether both institutions and outcomes are the result of underlying interests and resources" (Lowry, 2001, p. 853). To mitigate this problem, he included states that had not recently modified their governance structures. Lowry rationalized 
that the governance structures had originally been created to reduce redundancy and justify program offerings. Their original purpose was not to allocate resources.

Lowry found that institutions in states with centralized governance structures had lower tuition levels than other schools and those that had more autonomy in the trustee selection process charged more for tuition than other schools. Institutions with medical schools and law schools spent more for instruction and academic support activities (Lowry, 2001).

It appears that the best indicators for tuition prices are type and quality level of institutions, state economic characteristics, political power and type of governance structure. It appears that Institutional financial aid primarily represents activity in the market to attract students with certain characteristics. For this reason, institutional financial aid will be excluded from the equation for instructional services.

The analysis of tuition prices has not been detached from activities in the other higher education markets. Institutional and governmental financial aid as well as direct state appropriations to institutions may affect tuition prices. If the tuition pricing analysis is isolated from these other markets, a clearer understanding of tuition rate setting practices may be acquired. To determine the benefits of low tuition rates realized by families with different income levels, the analysis of tuition must conducted separately from financial aid.

\section{Market for Value Provided to Contributors}

The studies regarding charitable donations primarily examined the characteristics of institutions and students. The studies used data from surveys conducted by national organizations. 
Charitable contributions received by an institution are primarily the result of the school's characteristics. This view was shared by Marudas and Jacobs (2004) who developed a model for the donations to nonprofit organizations including colleges and universities. Their study included the data for 838 nonprofit organizations from 1985 through 1994. Nonprofit entities with more than $\$ 10$ million in assets and $\$ 100,000$ in annual donations were included in the analysis. The authors proposed that donations were a function of total fundraising expenses, donations received in the previous year, age of the organization, revenues received from governmental agencies, and the relationship of age and fund raising expenditures (Marudas \& Jacobs, 2004).

The authors retrieved data from the National Center for Charitable Statistics Statement of Income database for the years 1985 through 1994. These data were collected from IRS Form 990 Returns of Organizations Exempt From Income Tax (Form 990 returns).

As the authors proceeded with their testing, the interaction of age and fundraising expenses resulted in excessive multicollinearity. As a result, this variable was dropped. A two stage regression analysis was used to reduce the effects of endogenous variables.

The authors found that the relationship of fund raising costs and revenues from donations was not significant for higher education institutions. On the other hand, the age of an institution and its previous fund-raising experience is significant.

The findings of other researchers contradicted the conclusions of Marudas and Jacobs (2004)regarding the relationship of fundraising expenses to donations. The correlation of fundraising efforts with the level of contributions received was the subject of several research studies. The results of these studies are useful because they can inform budget decisions regarding fund-raising expenses. Gottfried and Johnson (2006) developed a model to study this topic. The authors used data from the Council for Aid to Education, the National Collegiate 
Athletic Association, the Wharton Data Research Services Center and the Bureau of Labor Statistics for their study. The authors analyzed the relationship of alumni donations and the number of solicitations at 117 top tier schools as defined by the U.S. News and World Report (Gottfried \& Johnson, 2006) . The authors found a significant relationship between alumni giving and solicitation at the $1 \%$ level. They determined that " ...by soliciting one additional alumnus, a school can expect to receive $\$ 10$ to $\$ 33$ in additional alumni donations" (Gottfried \& Johnson, 2006, p. 13). The authors also ascertained that the number of alumni solicitations is related to the revenues received from alumni donations and the endowment level. A dummy variable was used to analyze schools with successful football programs. If a school won a Bowl Championship Series game, this attribute was included in the analysis. In this study, football success had an insignificant relationship to alumni giving.

The longitudinal study conducted by Marudas and Jacobs described the behavior of the economic variables over many years. This type of research is helpful for the study of institutional contributions because donations may vary over time for a number of reasons. Ehrenberg and Smith conducted a study to determine why contributions to colleges and universities for certain purposes vary over time and by institution. The purposes identified by the authors were current expenditures, buildings, and equipment and endowment. They selected 30 institutions ranked by the U.S. News and World Report as national liberal arts colleges and research universities for the study. Data from the Council for Aid to Education for fiscal years 1968-69 through 1998-99 were utilized. Data regarding chief executive officers were obtained from Fortune and Professor Kevin Murphy of the University of Southern California (Ehrenberg \& Smith, 2003).

The authors found that alumni and institutional characteristics influence the level of contributions received. The number of Fortune 500 chief executive officers who were alumni 
correlated with higher alumni giving. Programs such as business and engineering influenced the amount of contributions received. The size of an institution's endowment, faculty research volume and the ratio of alumni to current students have a positive relationship to giving.

The authors also found relationships between donor characteristics and the uses of the contributions. Colleges and universities with a large percentage of graduates in business and engineering receive more donations for buildings and equipment (Ehrenberg \& Smith, 2003). Because the current level of an institution's endowment has a strong influence on the level of contributions received, the authors concluded that donations to wealthy colleges and universities would continue to increase more than to poorer institutions.

The measurement of the association of lagged variables with current contribution levels may provide a more accurate analysis of contribution activity. Cunningham and Cochi-Ficano (2002) performed a study of determine the relationship between student and institutional characteristics from 1984 for 400 institutions and the level of donations received from these schools from 1996 through 1998. The authors used data from the Voluntary Support of Education Database maintained by the Council on Aid to Education. In addition, data were collected from a proprietary database maintained by Peterson's Higher Education Research Division (Cunningham \& Cochi-Ficano, 2002).

Cunningham \& Cochi-Ficano included the level of instructional and student development efforts in the institutional characteristics selected for analysis. Variables were selected and categorized by student quality, institutional value added, alumni taste for giving, and wages. The authors used class rank, the percentage of the entering class who were national merit scholars and scores on national tests for student quality. For institutional value added, they used faculty to student ratio, percentage of full time faculty with a doctorate, and the number of bound volumes 
in the library per student (Cunningham \& Cochi-Ficano, 2002). Institutional control characteristics, National Collegiate Athletic Association affiliation, religious affiliation, and level of scholarship expenses were included in the alumni taste for giving category. Finally, the wage category included sex and minority compositions of the schools, percentage of graduate who enrolled in post-graduate business programs, dentistry, engineering, arts and sciences, law, medicine, theology, and veterinary medicine.

The authors determined that several lagged variables have a significant relationship to alumni giving. They found that "an institution's average donation per alumni increases between $\$ 61$ and $\$ 87$ for every standard deviation (120-point) increase in lagged mean SAT score" (Cunningham \& Cochi-Ficano, 2002, p. 552). Institutions that are part of larger systems and those schools that send many graduates to business schools receive fewer donations from alumni. Liberal arts institutions receive more donations per alumni than other colleges and universities. The authors did not find significant relationships between alumni giving and institutional efforts to raise money from alumni, intercollegiate athletics, religious affiliation and the sex and minority composition of alumni.

The alumni characteristics included in the Cunningham and Cochi-Ficano study may not be independent of institutional characteristics. If family wealth is passed on through generations, alumni of expensive schools may be in a better position to contribute than graduates of low-cost alternatives. Baade and Sundberg (1996) sought to separate the effects that institutional quality and student wealth have on alumni giving. They believed that the inclusion of these characteristics in a study caused problems because of collinearity. The authors used a log-linear equation to define institutional and individual characteristics that relate to alumni giving. 
Approximately 125 public and private doctoral-granting research universities and 250 liberal arts colleges were selected for the study. These institutions were analyzed using data for fiscal years 1989 and 1990. The data were collected from Peterson's Guide to Four-Year Colleges and IPEDS. In addition, data from the Council for Aid to Education were used.

The authors created variables for minority status, sex, tuition and fees charged, scholarship and fellowship per student, percentage of students in the top ten percent of their high school class, percentage of applicants accepted, enrollment, research expenditure per student, the number of alumni of record per student, and the number of alumni divided by the alumni of record.

A variable for instructional expenditures per student was also created. The inclusion of this variable created an endogeneity problem, because instructional expenditures may depend on alumni giving. To address this problem, the authors used a two - stage regression analysis.

The authors found that the contributions of alumni are higher at private institutions compared to public schools. The found that "... students willing and able to attend higher-cost colleges, and more of them who are able to do so without financial aid, translates into higher gifts..." (Baade \& Sundberg, 1996, p. 79). They also found that student ability, institutional quality, and age of the institution were significantly correlated with alumni giving.

Personal relationships developed while students are in school may influence the level of contributions made by alumni. In a study conducted in 2003, Clotfelter examined these connections to determine their effect on giving. The author selected variables that reflected the extent of personal connections alumni developed with their institutions. Variables were identified for characteristics of alumni when they were in school, such as their status as a student athlete. Whether or not a student had a mentor was also included as a variable. The study included 
variables for household income, marital status, number of children, occupation of parents, sector of employment, type of high school attended, high school rank, SAT score, college major, honors received graduation status, post-graduate degrees, aspects of the undergraduate experience, and student attitude (Clotfelter, 2003).

Clotfelter used a data set provided by the Andrew W. Mellon Foundation to study alumni giving at 34 universities. The author examined data for three cohorts of alumni who were surveyed in 1995 and 1996. The participants in the sample had enrolled in 1951, 1976 and 1989. Additional data were collected from 14 institutions regarding the donations made by each alumnus for a period of years. Most of the study utilizes data for 2,910 alumni from the 1951 cohort and 9,304 alumni from the 1976 cohort (Clotfelter, 2003).

The author found that having a mentor while in college resulted in a positive correlation for giving to an institution. Significant relationships were identified regarding alumni who attended a public high school and graduated from the institution that was their first choice. A strong relationship between alumni giving and both professional degrees and income was also identified. Status as an athlete, participation in extracurricular activities, state of residence, and academic major did not correlate with levels of donations. Clotfelter concluded that alumni who had personal connections with their institutions were more likely to donate after they graduated.

In summary, it appears that institutions with large endowments, high selectivity, and programs that provide lucrative job opportunities for graduates receive more revenues from donations than other schools. Schools that provide mentoring opportunities can also increase their revenues from donations.

Although it may be helpful in some circumstances to understand the association between donations and student and alumni characteristics, this study will examine institutional 
characteristics. Ultimately, the student and alumni characteristics will depend upon the institutional characteristics and its ability to attract capable students. The ability of alumni to donate will depend upon the quality of instruction and student development they receive as well as their degree programs.

\section{Market for Value Provided to Governments}

The studies in this section primarily analyzed the characteristics of the state within which the institution was located. Both political and economic factors were considered. For the purposes of this study, economic factors will be considered to be institutional characteristics related to their location.

Governmental bodies exercise control over both tuition levels and direct appropriations. Legislators may not receive pressure to permit tuition increases if appropriations must be reduced. Multiple equations must be used to examine this relationship. Koshal and Koshal proposed that “ "... tuition at public institutions is dependent upon state appropriations (subsidy) and, in turn, state appropriation is dependent upon the net tuition that may be charged to students" (Koshal \& Koshal, 2000, p. 83). They used a simultaneous equation to examine these relationships. Data from The Statistical Abstract of the United States for 1990 were used by the authors. The first equation in their model predicted that tuition was a function of appropriations, median family income and the out - of - state enrollment as a percentage of the total enrollment. In the second equation, the authors proposed that appropriations per full-time equivalent student (FTE) are a function of the tuition per FTE, per-capita tax revenue and the current enrollment as a percentage of the sum of the high-school graduates for the last four years and the political power in the legislature (Koshal \& Koshal, 2000). 
Two additional regressions were calculated. For the second set of equations, the authors introduced dummy variables to compare appropriations and tuitions by the regions where states were located. A dummy variable for the states of Delaware and Vermont was introduced for the third set of equations because the tuition levels for these states were unusually high. Because the model used a simultaneous equation, the authors chose to use a two-stage least squares method (Koshal \& Koshal, 2000).

The authors concluded that "...there are two-way interactions - with appropriation affecting tuition and, in turn, tuition affecting appropriation" (Koshal \& Koshal, 2000, p. 88). They also found significant relationships between tuition and median family income, the percentage of out - of - state students, and region. Relationships between state appropriations and tax revenue per capita, enrollment in 2-year institutions, enrollment participation rate and political power in state legislatures were determined in the study (Koshal \& Koshal, 2000).

In addition to the determinants identified by Koshal \& Koshal, other political characteristics affect state appropriations. These characteristics are reflected in the governance structures used by states. The primary focus of a study performed by Lowry was the governance structure of public higher education. Lowry used information from the 1994 IPEDS data set, U.S. News and World Report Research and Educational Association, National Association of Research and Land-Grant Colleges, Education Commission of the States, U.S. Bureau of the Census, and the U.S. Department of Commerce.

Lowry proposed that state appropriations are a function of the state government's resources, political interests in the state, enrollments, public benefits produced by institutions, institutional characteristics, institutional costs and other revenues (Lowry, 1999). The author found that state government funding of public education is positively related to the level of tax 
revenues. The number of governing boards within a state has a negative effect on state funding levels. Although state funding was positively correlated with enrollment levels, the relationship was more significant for in-state students than out-of state and graduate students. Public service activities were rewarded with higher levels of state funding than research. Tuition and fees were positively correlated with state government funding (Lowry, 1999). State funding of public institutions is also lower in states with higher elderly populations and large private institutions of higher learning (Lowry, 1999).

Another state characteristic that can affect the level of state appropriations is the existence of tax revolt legislation. The tax revolt and its affect on funding for higher education was the subject of a study performed by Archibald and Feldman (2006). To limit the tax burden on citizens, many states began to limit state spending in the 1970s. Two types of legislation have been used. Tax and Expenditure Limitation (TEL) “...limits the growth of state revenue or expenditures to some outside indicator, most commonly the growth of state personal income." Super Majority Requirements ("SMRs") require a defined percentage of the legislative vote for approval of tax increases (Archibald \& Feldman, 2006, p. 1).

The authors proposed that state appropriations are a function of TEL, SMRs, state-level political variables, other state spending, and demographic controls. They used ratings from the Americans for Democratic Action and AFL/CIO's Committee on Political Education to provide determinants of states' political climates. They also included party affiliations of the Governors and the majority membership of the legislatures. The age-related characteristics of the states' populations were also included (Archibald \& Feldman, 2006). Other data sources include the U.S Census Bureau, and the Public Interest Institute (Archibald \& Feldman, 2006). 
The authors found that TEL and SMRs have a significant effect states' spending on higher education. They determined that in regards to decreases in state spending on higher education, "the presence of a TEL accounts for more than one third of the average decline while the presence of an SMR accounts for roughly one fifth of the average decline" (Archibald \& Feldman, 2006, p. 22) .

The economic and political characteristics of a state have an effect on the level of state appropriations to higher education. It appears that the existence of tax revolt related legislation also affects state support for higher education. Although there may be a relationships between appropriations and tuition levels, these factors may not be independent. Tuition may increase when there are cuts in state funding and in other circumstances appropriations may increase to reduce the need for tuition increases. State governments may try to promote the development of human capital by keeping tuition levels as low as economic circumstances will allow. Lawmakers may also be sensitive to their constituents concerns regarding the rising costs of education. For the purposes of this study, the analysis of tuition will be confined to the market for educational services.

\section{Market to Attract Students with Certain Characteristics}

Several studies have been conducted to determine the relationship of financial aid and student characteristics. Most of the studies considered financial aid disbursements in relation to tuition prices. The value received by students is difficult to determine because wealthy institutions can provide scholarships from endowments and public institutions can use state appropriations to keep tuition and fees low. In both of these circumstances, the tuition price may not reflect the market value for educational services. The tuition prices for top-tier institutions 
may not reflect subsidies provided to all students, regardless of their characteristics, from endowment earnings. Likewise, the tuition prices at public institutions do not reflect the subsidies provided by state appropriations.

Some prices for certain student characteristics may reflect the variations that exist in higher education market segments. These market segments are not typically defined by products sold. For example, an English degree may be obtained at a small, private exclusive college or a large research university. Although the names of the degrees are the same, the educational experiences are likely to be very different at the two institutions. The market segments may be better defined by the type of institution. To attract the interest of a school, the student must demonstrate interest in the type of education provided by the institution. The segment of interest may be considered as a student characteristic because it originates from the student.

It appears that financial need and academic ability are two characteristics for which institutions are willing to expend resources. The results of several studies supported this phenomenon. Lawson and Zerkle (2006) performed a study to determine which student characteristics are rewarded with financial aid by college and universities. They proposed that the financial aid awarded was a function of financial need, high school percentile, high school GPA, raw ACT composite score, math and English scores, sex, race, religion, and state residency status (Lawson \& Zerkle, 2006). They studied students at a single institution for the fall of 1999.

The authors found that institution awarded financial aid for need, merit and minority status. For merit related-attributes, students' high school class rank was the best predictor. High school GPA was also robust. Students with higher ACT scores also received more financial aid. A non-white student received more financial aid, ceteris paribus, than a white student (Lawson \& Zerkle, 2006). 
Kim (2004) performed a study to find the determinants of institutional financial aid and their effect on degree completion. The author used data from the National Postsecondary Student Aid Study for fiscal year 1996 and 2000 as well as IPEDS data and the National Center for Educational Statistic's Beginning Postsecondary Students Longitudinal Study (BPS): 1996/2001 (Kim, 2004).

Kim found that significant relationships exist between institutional aid, financial need and academic merit. The author also learned that the average institutional aid awarded at public institutions was significantly less than the amount provided at private schools. According to Kim (2004), “...the relative importance of academic merit to financial need is larger for students in public institutions than students in private institutions." Institutional characteristics that were significant included the percentage enrollment of minority students, level of in-state tuition and the institutions' statuses as public schools. The author believed that public institutions rely primarily on low tuition rates to attract students with financial need.

An institution's status as a public or private school can affect the level of institutional financial aid. The differences in this status may not be easily attributed to the different market segments. For example, public research universities may offer an equivalent education to a private research university. Kim included student and schools' status as public or private institutions in a study conducted in 2004.

The inclusion of an institution's status as a public or private school required special procedures in Kim's research. The potential for endogenous variables was analyzed because the enrollment choice of students is dependent upon the amount of financial aid they are offered. A two - stage estimation procedure was employed to correct for this problem. The tuition gap between public and private four-year institutions was used as an instrumental variable because it 
was related to a student's choice of college type but not related to a student's institutional financial aid award. The unemployment rate of state, labor force participation rate and per capita income were added as instrumental variables (Kim, 2004).

The institutional aid for needy students identified by Kim may be subsidized by other students who pay full price. Many institutions claim that high levels of tuition produce revenues allow them to subsidize the cost of education for some students. Rose and Sorensen examined the tuition pricing of 502 private institutions to determine if the level of tuition and fees was related to net cost paid by needy students. The authors proposed that the cost of attendance is a function of the tuition price, student's ability to pay, and the average financial aid award (Rose \& Sorensen, 1992). They believed that tuition and fees available for needy students would exceed an expected tuition cost for the institution. This expected cost was determined by comparing schools of similar scores from the Barrons Index of Institutional Selectivity. Additional dummy variables were developed to segregate the schools by Carnegie Foundation classifications. Endowment income and federal research grant overhead dollars were also included in the regression equation. In addition, a variable was included for the total institutionally funded needbased grant and scholarship aid awards for undergraduate students divided by full-time undergraduate enrollment. A final variable was added for the percentage of undergraduate students that received any form of grant or scholarship aid. The authors also compared the administrative costs and instructional costs to the levels of tuition.

The data for these regressions were retrieved from the U.S Department of Education's Higher Education General Information Survey (HEGIS) and the American Survey of Colleges (ASC) for 1985 and 1986, published by the College examination Board (Rose \& Sorensen, 1992). 
Rose and Sorensen found that “...while institutions that appear to inflate their tuition do make larger financial aid awards, their awards are not large enough to reduce the average net price paid by needy students" (Rose \& Sorensen, 1992, p. 74). They also determined that high tuition levels were related to increased levels of administrative and instructional costs. They concluded that the high levels of tuition and fees were being used to pay administrators and professors.

It is difficult to determine if the discounting practices described by Rose and Sorensen are the result of institutions' efforts to increase revenues or to attract students with certain characteristics. Archibald (2002) examined financial aid disbursements at highly selective institutions to determine the expenditures of financial aid to attract students with certain qualities versus price discounting. The basis of his study was a theory proposed by Bowen and Brenaman in 1993 regarding schools' use of financial aid. Bowen and Brenaman believed that highly selective colleges and universities could maintain enrollments without providing any financial aid from institutional resources. They believed that these institutions awarded financial aid to attract qualified students who could not afford to come otherwise, including students who will contribute to the diversity of the student population and, ultimately, to the needs of the nation for more well-educated students from racial minorities and disadvantaged backgrounds (Bowen \& Breneman, 1993).

Bowen and Brenaman proposed a test to determine the percent of financial aid awarded to attract students with certain characteristics and the percent used to discount tuition prices. They believed that if increases in financial aid increased net revenues, it was being awarded as a discount. If increases in financial aid did not result in increased net revenues, the additional awards were made to attract students with certain characteristics. 
Archibald selected IPEDS data for 30 of the top 42 national liberal arts colleges designated by the U.S. News and World Report for 2000. He proposed that the result of tuition multiplied by enrollments minus institutional financial aid plus gift, endowment, and governmental income was a function of instructional costs plus research revenues minus related costs. He designated separate variables for total, federal, and state financial aid.

Because the tuition and fee revenues collected by colleges and universities did not equal tuition prices multiplied by student FTE, Archibald substituted the tuition and fees divided by tuition prices for student FTE. He examined the changes in discount per student (calculated as total aid minus governmental aid divided by enrollment from 1987 through 1996 (Archibald, 2002). He found that “...larger increases in tuition discounting are associated with larger increases in tuition, but there is no statistically reliable association between increases in tuition discounting and either instructional expenditures or net tuition revenues" (Archibald, 2002, p. 119).

The studies indicate that institutional financial aid is awarded to students with evidence of strong academic performance in high school and students with financial need. Relationships also existed between institutional financial aid and minority status.

To understand the market to attract students with certain characteristics, it is necessary to understand the traits that make these students attractive to colleges and universities. The ability of an institution to attract these students represents activity in the markets for tuition, donations, state appropriations and governmental financial aid. 


\section{Market to Provide Governmental Funds to Students}

In the interest of economic development, governments award financial aid directly to students. The potential for institutions to raise tuition levels as grant funds increase exists. This potential is less for state financial aid because states have the ability to control both public tuition and financial aid awards. Singell and Stone (2007) performed a study to determine if there is a relationship between increases in federal financial aid grants and increases in tuition prices. The authors proposed that tuition is a function of external funding, a time trend, time-invariant university attributes and Pell grants per recipient. They compared in-state and out-of-state students for public institutions. In addition, they analyzed data for private and public colleges and universities. The external support included state appropriations and donations.

The authors used data from the Computer-Aided Science Policy Analysis and Research Database System and the U.S Department of Education. They included 475 four-year public universities and 1079 private universities that had at least 6 years of complete and contiguous data(Singell \& Stone, 2007). From these data, the authors found no significant relationship between increases in Pell grants and increases in in-state tuition prices. On the other hand, a significant relationship was identified between Pell grant increases and out-of-state tuition prices for public institutions. In addition, a significant relationship was identified between Pell grant increases and tuition prices for private institutions.

It appears that a relationship may exist between federal financial aid and out-of-state tuition levels at public institutions and all tuition prices at private schools. The relationship for in-state tuition levels may not exist because states may maintain low tuition levels to reduce the cost of state-financial aid. 


\section{State Subsidies of Public Higher Education}

State governments appropriate funds to public institutions to keep tuition costs low for students. The below - market rates for tuition are enjoyed by students from affluent families as well as students from middle and low-income families. Baum and Sjogren estimated average direct and indirect subsidies using data from the National Postsecondary Student Aid Study for 1989 and IPEDS. The study defined direct subsidies as "financial aid received by the student". The authors identified indirect subsidies as “...the difference between the institution's cost of providing education and the amount of tuition and fees charged by the institution" (Baum \& Sjogren, 1996, p. 197). The authors found that students from families with incomes less than $\$ 12,000$ received total subsidies of $\$ 15,184$ from public institutions compared to $\$ 14,723$ at private institutions. Students from families with more than $\$ 100,000$ in income received subsidies of $\$ 12,223$ at public institutions and $\$ 2,430$ at private institutions (Baum \& Sjogren, 1996).

The combination of below - market public tuition rates and direct state financial aid result in significant studies for families in all income categories. On the other hand, private institutions appear to match tuition rates and financial aid to the family income levels of their students.

\section{Limitations of Previous Studies on Higher Education Econometric Models}

Studies of higher education econometric models have not utilized the multiple market theory proposed in Chapter 3. As a result, researchers may have included variables to define a market which are more closely related to activities in other markets. For example, Tiffany and Ankrom's (1998) model did not consider the possibility that institutions provide financial 
resources to students with certain characteristics. Much of the activity they observed may have been related to schools' efforts to improve the incoming quality of their student bodies.

Koshal and Koshal's (2000) study did not recognize a market for the development of human capital reflected by state appropriations. Although the interaction of tuition and state appropriations may help to explain the relationship between them, their study does little to explain the market activity for Instructional Services or human capital development. Rose and Sorensen (1992) assumed that tuition was discounted by institutions to provide need - based aid or to maximize revenues rather than to attract students with certain characteristics. It appears that Lawson and Zirkle (2006) also did not consider the possibility of multiple markets in higher education. Their study does not acknowledge that governmental entities may provide financial aid to develop human capital. Although Archibald (2002)discussed the importance of attracting students with strong academic skills, he did not recognize institutional commitments of resources to these students as a distinct market.

Some of the variables identified in several studies appeared to have limited utility. Cunningham and Cochi-Ficano's (2002) model included many alumni characteristics that may not have a direct effect on the market for donations. Many alumni characteristics may be a result of an institution's admissions criteria and program characteristics. If an institution admits highperforming students into programs that produce graduates who enter high-paying fields, the schools level of donations should be high. The historical ability of an institution to provide economic resources to students with certain characteristics may have a positive influence on its ability to attract donations. The alumni characteristics may therefore be the lagged result of an institution's activity in the market for students with certain characteristics. 
Although it may be true that current donations are a function of previous year's contributions, as proposed by Marudas and Jacobs (2004), this information may not be useful. It is difficult to determine a strategy a poor institution would implement to take advantage of this knowledge, other than working towards the obvious goal to increase fundraising efforts. Most institutions do not begin their existence with high levels of contributions. At some point in their existence, it is likely that wealthy institutions developed characteristics that made them attractive to donors.

It appears that variables could have been added to several studies to enhance the quality of the research. The authors who studied the determinants for state appropriations did not consider the historical need to develop human capital by funding certain majors. It may be more common for students to be education or engineering majors at public institutions than at private schools. A variable for program offerings would have provided insight regarding governmental efforts to develop human capital.

Although Singell and Stone (2007) found a relationship between increases in Pell grant funding and increases in tuition prices at private institutions and for out-of-state tuition prices at public institutions, they did not include some variables that may have had any effect on tuition price increases. For example, changes in the income levels of students' families may have allowed institutions to increase prices for all students.

It does not appear the Archibald (2002) performed statistical tests of his equation describing the relationship of institutional revenues and expenses. Simultaneous equations may also exist in the model. For example, the tuition prices, enrollment, and institutional financial aid may correlate with the level of expenditures needed by the institution to operate. At the same time, the level of expenditures may depend on how much revenue the school can generate from 
tuition prices multiplied by enrollment less institutional discounts. In addition, institutional research expenses may also be a function of the expected tuition and fee revenues.

Some of the studies were limited by their scope. For example the studies conducted by Gottfried and Johnson (2006), Erenberg and Smith (2003), and Baade and Sundberg (1996) were limited to selective private colleges and universities. Complete data for only 400 schools were available for the research conducted by Cunningham and Cochi-Ficano (2002). The study conducted by Rose and Sorensen (1992) included only private institutions. Kim's (2004) study was limited to institutional financial aid. The data for Lawson and Zirkle's (2006) research were limited to a single institution.

Although the age of several studies limits their usefulness to some degree, they are valuable resources for theoretical and practical information. Limitations exist because the economic circumstances have changed over the years and the assumptions and results may not be relevant today. Financial accounting practices have also improved in higher education. For example, the allocation of capital costs by accounting for depreciation provides information regarding the physical facilities of an institution. Research must be performed using recent data to acquire a better understanding of contemporary higher education economics.

\section{Summary}

Many econometric studies of higher education have been performed. Rather than examine higher education economics as a whole, researchers typically focus on one or more segments. Some studies such as the examination of tuition and fees in relation to financial aid combine the economic activities of multiple markets in single equations. The blending of markets appears to obscure the characteristics attributable to each segment. To understand 
higher education economics, the activities in each market should be analyzed separately. After this analysis is conducted, the activities in each market should be examined in relation to the whole. It does not appear that studies have been conducted to determine if public institutions are funded in accordance with the original intent of their founders.

It appears that the determinants for higher education econometric equations may be drawn from institutional characteristics, student characteristics, and the economic and political characteristics of states. Some econometric determinants are related to more than one market. It appears that the relevant determinants for markets within which institutions act as sellers are drawn from institutional characteristics and the economic and political characteristics of the states. Included in this group are the markets for instructional services, institutional characteristics that attract donations and economic development funded by appropriations.

Likewise, the determinants appear to be similar for students with certain characteristics and the markets to provide governmental funds to students with certain characteristics. Student characteristics and the economic and political characteristics of a state appear to be the best determinants for these markets. The market for federal financial aid also appears to be determined by student characteristics.

The determinants that appear to be most useful for higher education policy makers are the characteristics of the sellers. These attributes can be changed more easily by the seller than the characteristics of the buyer. 


\section{CHAPTER THREE \\ Research Methodology \\ Introduction}

The purpose of this chapter is to describe the methodology used to examine the determinants of the higher education markets identified in this study. The first section describes the econometric equations developed from the theory described in Chapter Two. The succeeding sections describe the research design, population and sample, and the data analysis.

\section{Econometric Models for Higher Education Markets}

To illustrate the demand curves for the markets within which higher education institutions operate, econometric models may be used. The equations are constructed to identify the characteristics of the sellers of educational services, institutional characteristics, economic development activities, and student characteristics. Except for colleges and universities' statuses as public or private institutions, buyer's characteristics are excluded from the equations. It is a purpose of this study to identify the characteristics of sellers which attract buyers to them. Although buyer's characteristics may be influenced by the market, they are not within the scope of this study. Colleges or universities' statuses as public or private institutions are included in all equations because appropriations appear to affect all markets. For each market, the dependent variables are analyzed for pubic and private institutions. For each market, separate equations were developed for private and public institutions. The differences between the dependent variables for public and private institutions were analyzed. The equation numbers correspond to the hypothesis and research question numbers. For example, equation 1a corresponds to hypothesis 1a and research question 1a. 
For the Instructional Services market, a model should reflect institutional characteristics that attract students. This market may also be influenced by the wealth of the families whose students enroll in schools. Public institutions' tuition levels may also be influenced by political power in a state. The following equations are proposed for the higher education services market. Equation 1a was used to address research question 1a: Is there a statistically significant relationship between the amount of tuition and fees per student charged to in-state students by public institutions, institutional characteristics, and the economic and political characteristics of the states? Equation $1 \mathrm{~b}$ was used to address research question 1b: Is there a statistically significant relationship between the amount of tuition and fees per student charged to in-state students by private institutions, institutional characteristics, and the economic and political characteristics of the states? Equation 1c was developed to address research question 1c: Does the amount of tuition and fees per student charged to in-state students at private institutions differ significantly from the in-state tuition charged to in-state students at public institutions? Equation 1d was used to address research question 1d: Is there a statistically significant relationship between the amount of tuition and fees per student charged to out-of-state students by public institutions, institutional characteristics, and the economic and political characteristics of the states? Equation 1e was used to address research question 1e: Is there a statistically significant relationship between the amount of tuition and fees per student charged to out-of-state students by private institutions, institutional characteristics, and the economic and political characteristics of the states? Equation 1f was developed to address research question 1f: Do the amounts of tuition and fees per student charged to out-of-state students at private institutions differ significantly from the out-of-state tuition charged to out-of-state students at public institutions? Equation 1a: $\mathrm{TPBI}_{\mathrm{i}}=\mathrm{SE}_{\mathrm{i}}+\mathrm{CC}_{\mathrm{i}}+\mathrm{CR}_{\mathrm{i}}+\mathrm{DEM}_{\mathrm{i}}+\mathrm{DEPRPB}_{\mathrm{i}}$ 
Equation 1b: $\mathrm{TPVI}_{\mathrm{i}}=\mathrm{SE}_{\mathrm{i}}+\mathrm{CC}_{\mathrm{i}}+\mathrm{CR}_{\mathrm{i}}+\mathrm{DEM}_{\mathrm{i}}+\mathrm{DEPRPV}_{\mathrm{i}}$

Equation 1c: TPBI < TPVI

Equation 1d: $\mathrm{TPBO}_{\mathrm{i}}=\mathrm{SE}_{\mathrm{i}}+\mathrm{CC}_{\mathrm{i}}+\mathrm{CR}_{\mathrm{i}}+\mathrm{DEM}_{\mathrm{i}}+\mathrm{DEPRPB}_{\mathrm{i}}$

Equation 1e: $\mathrm{TPVO}_{\mathrm{i}}=\mathrm{SE}_{\mathrm{i}}+\mathrm{CC}_{\mathrm{i}}+\mathrm{CR}_{\mathrm{i}}+\mathrm{DEM}_{\mathrm{i}}+\mathrm{DEPRPV}_{\mathrm{i}}$

Equation 1f: TPBO < TPVO

TPBI is the amount of in state tuition and fees per student charged by public institution $i$, TPVI is the amount of in state tuition and fees per student charged by private institution $i$, TPBO is the amount of out of state tuition and fees per student charged by public institution $i$, TPVO is the amount of out of state tuition and fees per student charged by private institution $i \mathrm{SE}$ is the selectivity of the institution, $\mathrm{CC}$ is its Carnegie Foundation classification, $\mathrm{CR}$ is per-capita tax revenue for the state in which the school is operated, DEM represents the political power in the legislature. The DEM variable is determined by using the weighted average party composition over a six-year period. If the Democratic Party has more than $55 \%$ of the seats, the value is 1 . Conversely, if the Democratic party does not have a clear majority, the value is 0 (Koshal \& Koshal, 2000). DEPRPB is public institution annual depreciation expense per student and DEPRPV is private institution annual depreciation per student.

The following table describes the specific equation variables that correspond to the research question categories.

Table 1: Research question categories for equations 1a-af

\begin{tabular}{|l|l|}
\hline Research Question Categories & Equation Variables \\
\hline
\end{tabular}
Institutional Characteristics State Political and Economic Characteristics SE, CC, DEPRPB, DEPRPV CR, DEM

The depreciation variable is included to reflect the wealth and the level of economic resources available to an institution. Depreciation may be defined as the systematic allocation of 
the historical cost of on asset over its useful life (Williams \& Carcello, 2004). Depreciation expenses should reflect and institution' ability to fund capital expenditures including the renewal of facilities. Students may be drawn to institutions with quality facilities. This may be a better measure than endowment level for wealth. Many public institutions may substitute governmental capital funding for endowment and alumni giving. The benefit of a significant endowment may be more clearly identified with the market to attract students with certain characteristics.

State or federal sources of revenue may prove to be an adequate substitution or supplement for significant endowments by public institutions. The federal government and many state governments provide public institutions with significant funding for capital projects.

It is presumed that need and merit - based institutional aid is awarded to attract students with certain desirable characteristics. This equation also reflects the assumption that resources from governmental entities and private sources for financial aid reflect activities in other markets.

For public institutions, the tuition revenues will also include non-resident students. These students usually pay a higher amount than students who reside within a state. It appears that state governments do not wish to invest tax dollars in the education of non-resident students. They may assume that these students will return to the states that they came from after they finish their education. State governments may not study data regarding the number of non-residents who remain within a state after graduation or their economic impact on local communities while they are receiving an education.

The market for value provided to contributors is the subject of the next equation. This model should also reflect institutional characteristics that appeal to donors. Although it is useful to understand that students from wealthy families are more likely to contribute as alumni, 
these individuals probably chose an institution for its characteristics. Consequently, institutional characteristics are of primary relevance in the model. Equation $2 \mathrm{a}$ was used to address research question $2 \mathrm{a}$ : Is there a statistically significant relationship between the amount of revenues collected from private donations per student by public institutions, institutional characteristics and, academic programs? Equation $2 \mathrm{~b}$ was used to address research question $2 \mathrm{~b}$ : Is there a statistically significant relationship between the amount of revenues collected from private donations per student by private institutions, institutional characteristics, and academic programs? Equation 2c was developed to address research question2c: Do the amount of revenues collected from private donations per student by private institutions differ significantly from the amount of revenues collected from private donations per student donations received by public institutions?

Equation 2a: $\mathrm{DONPB}_{\mathrm{i}}=\mathrm{SE}_{\mathrm{i}}+\mathrm{CC}_{\mathrm{i}}+\mathrm{DEPRPB}_{\mathrm{i}}+\mathrm{PROGI}_{\mathrm{i}}$

Equation 2b: $\mathrm{DONPV}_{\mathrm{i}}=\mathrm{SE}_{\mathrm{i}}+\mathrm{CC}_{\mathrm{i}}+\mathrm{DEPRPV}_{\mathrm{i}}+\mathrm{PROGI}_{\mathrm{i}}$

Equation 2c: DONPB $<$ DONPV

$\mathrm{DONPB}_{\mathrm{i}}$ is the total amount of revenues collected from private donations per student for public institution $i, \mathrm{DONPV}_{\mathrm{i}}$ is the total amount of revenues collected from private donations per student for private institution i, SE is its selectivity, CC is its Carnegie Foundation classification, DEPRPB is public institution annual depreciation expense per student, DEPRPV is private institution annual depreciation per student, and PROGI is the variable for the institution's graduates by program obtained from IPEDS data. The graduates' majors were grouped into twelve program categories and each category was given a unique numeric value. These variables are listed in Table 2.

\section{Table 2: Program variables}




\begin{tabular}{|l|l|}
\hline PROGI1 & Humanities \\
\hline PROGI2 & "Social/behavioral sciences" \\
\hline PROGI3 & Life sciences \\
\hline PROGI4 & Physical sciences \\
\hline PROGI5 & Math \\
\hline PROGI6 & Computer/information science \\
\hline PROGI7 & Engineering \\
\hline PROGI8 & Education \\
\hline PROGI9 & Business/management \\
\hline PROGI10 & Health \\
\hline PROGI11 & Vocational/technical \\
\hline PROGI12 & Other technical/professional \\
\hline
\end{tabular}

The following table describes the specific equation variables that correspond to the research question categories.

Table 3: Research question categories for equations 2a-2c

\begin{tabular}{|l|l|}
\hline Research Question Categories & Equation Variables \\
\hline Institutional Characteristics & SE, CC, DEPRPB, DEPRPV \\
\hline $\begin{array}{l}\text { State Political and Economic } \\
\text { Characteristics }\end{array}$ & CR, DEM \\
\hline Academic Programs & PROGI \\
\hline
\end{tabular}

Fund raising expenses are not included in the equation because it is difficult to determine the appropriate figure to include in the equation. Information can be obtained for private institutions' and foundations' fund-raising expenses, but the expenses incurred by public institutions are not accounted for separately in the national datasets. These expenses would be included in the institutional support expense category and could be substantial. In addition, much of the work performed by college and university presidents may be efforts to raise money. Presidential salaries are also typically included in the institutional support expense category.

The following equation reflects the market for value provided to state governments. Equation 3a was used to address research question 3a: Is there a statistically significant 
relationship between the amount of state appropriations per student received by public institutions, institutional characteristics, the economic and political characteristics of the states in which the institutions operate, academic programs, and the available pools of students within the states? Equation $3 \mathrm{~b}$ was used to address research question $3 \mathrm{~b}$ : Is there a statistically significant relationship between the amount of state appropriations per student received by private institutions, institutional characteristics, the economic and political characteristics of the states in which the institutions operate, academic programs, and the available pools of students within the states? Equation 3c was developed to address research question 3c: Do the state appropriations per student received by public institutions differ significantly from the state appropriations received by private institutions?

Equation 3a: $\mathrm{APPPB}_{\mathrm{i}}=\mathrm{SE}_{\mathrm{i}}+\mathrm{CC}_{\mathrm{i}}+\mathrm{CR}_{\mathrm{i}}+\mathrm{R}_{\mathrm{i}}+2 \mathrm{Y}_{\mathrm{i}}+\mathrm{DEPRPB}_{\mathrm{i}}+\mathrm{PROGI}_{\mathrm{i}}+\mathrm{DEM}_{\mathrm{i}}$ Equation 3b: APPPV $\mathrm{i}_{\mathrm{i}}=\mathrm{SE}_{\mathrm{i}}+\mathrm{CC}_{\mathrm{i}}+\mathrm{CR}_{\mathrm{i}}+\mathrm{R}_{\mathrm{i}}+2 \mathrm{Y}_{\mathrm{i}}+\mathrm{DEPRPV}_{\mathrm{i}}+\mathrm{PROGI}_{\mathrm{i}}+\mathrm{DEM}_{\mathrm{i}}$ Equation 3c: APPPB $<$ APPPV

APPPB is the amount of per student state governmental appropriations made to public institution $i$, APPPV is the amount of per student state governmental appropriations made to private institution $i, \mathrm{SE}$ is its selectivity, and $\mathrm{CC}$ is its Carnegie Foundation classification. A state's ability to support the institution is represented by CR, the variable for per-capita tax revenue for the state in which the school is operated. $\mathrm{R}$ is the variable for the current enrollment as a percentage of the sum of the high-school graduates for the past 4 years. The variable $2 \mathrm{Y}$ is included to reflect the percentage of students enrolled in two-year colleges, DEPRPB is public institution annual depreciation expense per student, and DEPRPV is private institution annual depreciation per student. PROGI is the variable for the institution's enrollments by program obtained from IPEDS data. Finally, DEM represents the political power in the legislature. 
The following table describes the specific equation variables that correspond to the research question categories.

Table 4: Research question categories for equations 3a-3c

\begin{tabular}{|l|l|}
\hline Research Question Categories & Equation Variables \\
\hline Institutional Characteristics & SE, CC, DEPRPB, DEPRPV \\
\hline $\begin{array}{l}\text { State Political and Economic } \\
\text { Characteristics }\end{array}$ & CR, DEM \\
\hline Academic Programs & PROGI \\
\hline Available pools of students within the states & R, 2Y \\
\hline
\end{tabular}

Although the per-capita tax revenue for a state may predict the level of state appropriations that colleges and universities receive, the equation may not represent a prudent investment strategy. If a state's per-capita income levels are low, it may be wise to invest a higher proportion of its tax revenues in higher education. The investment may yield higher levels of tax revenues in the future. As mentioned above, it does not appear that states perceive economic development value in the education of non-resident students. If state governments encourage non-residents to attend institutions by allowing appropriations to partially fund their education, the states may receive economic development value.

The economic development activities related to higher education have been limited in some states by efforts to reduce taxes. Some states have limited the growth in total expenditures to a percentage of a predetermined indicator such as personal income. Others have required supermajorities to approve tax increases. These laws may have decreased the amount of appropriation to higher education as a percentage of personal income compared to states without these restrictions. The effect of such appropriations limitations should be considered in the development of econometric equations for states with these laws (Archibald \& Feldman, 2006). 
The equation for state governments may not cover all of the possible variables. For example, a state government may be reluctant to close an institution in an economically depressed area because it provides employment. It would be difficult to measure the effect of loan forgiveness programs on the average tuition price because of uncertainties regarding student persistence and post-graduate employment. States often establish these programs to encourage graduates to work within their borders for a defined period of time.

Although the goals of state and federal governments both include economic and social development, an equation for value provided to the federal government will not be similar to the equation for state appropriations. Federal funds are primarily used to fund financial aid programs. The proportion of federal appropriations for institutional operations to financial aid disbursements is very low compared to most states' expenditures for higher education. It does not appear that research has been conducted to determine an econometric equation for this market. The receipt of federal funds may depend on an institution's status as a land grant or historically black college or university. The following equations reflect the econometric model for these markets. Equation 4a was developed to address research question 4a: Is there a significant relationship between the amount of federal revenues received by public institutions, their statuses as land grant institutions, institutional characteristics, and academic programs? Equation $4 \mathrm{~b}$ was developed to address research question $4 \mathrm{~b}$ : Is there a significant relationship between the amount of federal revenues received by private institutions, their statuses as land grant institutions, institutional characteristics, and academic programs? Equation 4c was developed to address research question 4c: Do the federal revenues received by public institutions differ significantly from the federal revenues received by private institutions? Equation 4a: $\mathrm{FRPB}_{\mathrm{i}}=\mathrm{STAT}_{2} \mathrm{i}_{\mathrm{i}}+\mathrm{STAT} 0_{\mathrm{i}}+\mathrm{SE}_{i}+\mathrm{CC}_{\mathrm{i}}+\mathrm{DEPRPB}_{\mathrm{i}}+\mathrm{PROGI}_{\mathrm{i}}$ 
Equation 4b: FRPV $=\mathrm{STAT}_{\mathrm{i}} 2_{\mathrm{i}}+\mathrm{STAT}_{\mathrm{i}}+\mathrm{SE}_{i}+\mathrm{CC}_{\mathrm{i}}+\mathrm{DEPRPV}_{\mathrm{i}}+\mathrm{PROGI}_{\mathrm{i}}$

Equation 4c: FRPB $<$ FRPV

The amount of federal operating revenues provided per student to institution $i$ is represented by the variable FRPB for public institutions and the variable FRPV for private institutions. STAT62 is the variable for an institution's status as an 1862 land grant institution, STAT90 is the variable for an institution's status as an 1890 land grant institution, SE is its selectivity, and CC is the variable for its Carnegie Foundation classification. DEPRPB is public institution annual depreciation expense per student and DEPRPV is private institution annual depreciation per student. PROG is the variable for the institution's enrollments by program. Table 5 describes the categories for equations $4 \mathrm{a}$ through $4 \mathrm{c}$.

Table 5: Research question categories for equations 4a-4c

\begin{tabular}{|l|l|}
\hline Research Question Categories & Equation Variables \\
\hline Statuses as Land Grant Institutions & STAT62, STAT90 \\
\hline Institutional Characteristics & SE, CC, DEPR \\
\hline Academic Programs & PROGI \\
\hline
\end{tabular}

The market in which institutions reduce prices to attract students may be described by these equations. Equation 5a addresses research question 5a: Is there a significant relationship between institutional merit-based financial grant aid paid per student by public institutions, student characteristics, and academic programs? Equation $5 \mathrm{~b}$ addresses research question $5 \mathrm{~b}$ : Is there a significant relationship between institutional merit-based financial grant aid paid per student by private institutions, student characteristics, and academic programs? Equation $5 \mathrm{c}$ was developed to address research question 5c: Do the amounts paid for institutional merit-based financial grant aid paid per student by public institutions differ significantly from the amounts paid for institutional merit-based financial grant aid paid per student by private institutions? 
Equation $5 \mathrm{~d}$ addresses research question $5 \mathrm{~d}$ : Is there a significant relationship between institutional need-based financial grant aid paid per student by public institutions, student characteristics, and academic programs? Equation 5e addresses research question 5e: Is there a significant relationship between institutional need-based financial grant aid paid per student paid by private institutions, student characteristics, and academic programs? Equation $5 \mathrm{f}$ was developed to address research question 5f: Do the amounts paid for institutional need-based financial grant aid paid by public institutions differ significantly from the amounts paid for institutional need-based financial grant aid by private institutions?

Equation 5a: $\mathrm{IFPBM}_{\mathrm{i}}=\mathrm{SA}_{\mathrm{i}}+\mathrm{SAGI}_{\mathrm{i}}+\mathrm{SR}_{\mathrm{i}}+\mathrm{SG}_{\mathrm{i}}+\mathrm{SPEL}_{\mathrm{i}}+\mathrm{SGPA}_{\mathrm{i}}+\mathrm{SVA}_{\mathrm{i}}+\mathrm{LOC}_{\mathrm{i}}+\mathrm{PROGN}_{\mathrm{i}}$ Equation 5b: $\mathrm{IFPVM}_{\mathrm{i}}=\mathrm{SA}_{\mathrm{i}}+\mathrm{SAGI}_{\mathrm{i}}+\mathrm{SR}_{\mathrm{i}}+\mathrm{SG}_{\mathrm{i}}+\mathrm{SPEL}_{\mathrm{i}}+\mathrm{SGPA}_{\mathrm{i}}+\mathrm{SVA}_{\mathrm{i}}+\mathrm{LOC}_{\mathrm{i}}+\mathrm{PROGN}_{\mathrm{i}}$ Equation 5c: IFPBM $<$ IFPVM

Equation 5d: $\mathrm{IFPBN}_{\mathrm{i}}=\mathrm{SA}_{\mathrm{i}}+\mathrm{SAGI}_{\mathrm{i}}+\mathrm{SR}_{\mathrm{i}}+\mathrm{SG}_{\mathrm{i}}+\mathrm{SPEL}_{\mathrm{i}}+\mathrm{SGPA}_{\mathrm{i}}+\mathrm{SVA}_{\mathrm{i}}+\mathrm{LOC}_{\mathrm{i}}+\mathrm{PROGN}_{\mathrm{i}}$ Equation 5e: $\mathrm{IFPVN}_{\mathrm{i}}=\mathrm{SA}_{\mathrm{i}}+\mathrm{SAGI}_{\mathrm{i}}+\mathrm{SR}_{\mathrm{i}}+\mathrm{SG}_{\mathrm{i}}+\mathrm{SPEL}_{\mathrm{i}}+\mathrm{SGPA}_{\mathrm{i}}+\mathrm{SVA}_{\mathrm{i}}+\mathrm{LOC}_{\mathrm{i}}+\mathrm{PROGN}_{\mathrm{i}}$ Equation 5f: IFPBN $<$ IFPVN

Institutional financial aid is a function of student and state characteristics. The variable for institutional merit-based financial aid paid by public institutions is IFPBM. The variable IFPVM is the variable for institutional merit-based financial aid paid by private institutions. The variable for institutional need-based financial aid paid by public institutions is IFPBN. The variable IFPVN is the variable for institutional need-based financial aid paid by private institutions. Student characteristics include age (SA), adjusted gross income (SAGI), race (SR), gender (SG), parent's education level (SPEL), grade point average (SGPA), veteran status (SVA), attend institution in state of legal residence (LOC) and students' majors obtained from 
NPSAS: 04 data (PROGN). The students' races were collapsed into 5 categories and each category was given a unique numeric value. These categories are described in Table 6.

Table 6: Race variables

\begin{tabular}{|l|l|}
\hline SR1 & White \\
\hline SR2 & Black or African American \\
\hline SR3 & Hispanic or Latino \\
\hline SR4 & Asian \\
\hline SR5 & Other \\
\hline
\end{tabular}

The parent's education levels were grouped into twelve categories and each category was given a unique numeric value. These variables are described in Table 7.

Table 7: Parent's education level variables

\begin{tabular}{|l|l|}
\hline SPEL1 & Do not know parent's education level \\
\hline SPEL2 & Did not complete high school \\
\hline SPEL3 & High school diploma or equivalent \\
\hline SPEL4 & Vocational or technical training \\
\hline SPEL5 & Less than two years of college \\
\hline SPEL6 & Associate's degree \\
\hline SPEL7 & 2 or more years of college but no degree \\
\hline SPEL8 & Bachelor's degree \\
\hline SPEL9 & Master's degree or equivalent \\
\hline SPEL10 & First-professional degree \\
\hline SPEL11 & Doctoral degree or equivalent \\
\hline
\end{tabular}

The state of residency status in relation to institution location was divided into two categories. $\mathrm{LOC} 1$ is the variable for in-state students and $\mathrm{LOC} 2$ is the variable for out of state students.

The student's majors were grouped into twelve program categories and each category was given a unique numeric value. These categories are described in Table 8.

Table 8: Program variables

\begin{tabular}{|l|l|}
\hline PROGN1 & Humanities \\
\hline PROGN2 & Social/behavioral sciences \\
\hline
\end{tabular}




\begin{tabular}{|l|l|}
\hline PROGN3 & Life sciences \\
\hline PROGN4 & Physical sciences \\
\hline PROGN5 & Math \\
\hline PROGN6 & Computer/information science \\
\hline PROGN7 & Engineering \\
\hline PROGN8 & Education \\
\hline PROGN9 & Business/management \\
\hline PROGN10 & Health \\
\hline PROGN11 & Vocational/technical \\
\hline PROGN12 & Other technical/professional \\
\hline
\end{tabular}

The following table describes the specific equation variables that correspond to the research question categories.

Table 9: Research questions for equations 5a-5e

\begin{tabular}{|l|l|}
\hline Research Question Categories & Equation Variables \\
\hline Student Characteristics & SA, SAGI, SR, SG, SPEL, SGPA, SVA, LOC, \\
\hline $\begin{array}{l}\text { State Political and Economic } \\
\text { Characteristics }\end{array}$ & CR, STLF, STUR, STTG, DEM \\
\hline Academic Programs & PROGN \\
\hline
\end{tabular}

Equation $5 \mathrm{c}$ was developed to address research question $5 \mathrm{c}$ : Do the amounts paid for institutional merit-based financial grant aid paid per student by public institutions differ significantly from the amounts paid for institutional merit-based financial grant aid paid per student by private institutions?

In addition to institutional scholarships, the federal government and state governments provide financial aid to students who meet their qualifications. The federal government also provides tuition benefits to veterans and tax credits for tuition payments. Students may use these resources to attend schools of their choice. The relationships between the students and governments represent additional markets. The econometric models for these markets are similar to the institutional financial aid model. Although the relationship is between the student and the 
government, the amount of expenditures depends on the characteristics of the student's college or university.

The econometric equations for governmental markets include parameters for party affiliation, the percentage of young adults enrolled in colleges and universities and the percentage of students enrolled in two-year institutions. The following equations represent the models for the federal and state financial aid relationships. Equation 6a addresses research question 6a: Is there a relationship between the amount of state merit-based financial grant aid received per student at public institutions, the amount of tuition and the fees per student charged to in-state students, student characteristics, and academic programs? Equation $6 \mathrm{~b}$ addresses research question 6b: Is there a relationship between the amount of state merit-based financial grant aid received at private institutions, the amount of tuition and the fees per student charged to in -state students, student characteristics and academic programs? Equation $6 \mathrm{c}$ was developed to address research question 6c: Does the amount of state merit-based financial grant aid received by students at public institutions differ significantly from the amount of state financial grant aid receive by students at private institutions?

Equation $6 \mathrm{~d}$ addresses research question $6 \mathrm{~d}$ : Is there a relationship between the amount of state need-based financial grant aid received at public institutions, the amount of tuition and the fees per student charged to in-state students, student characteristics and academic programs? Equation 6e addresses research question 6e: Is there a relationship between the amount of state need-based financial grant aid received at private institutions, the amount of tuition and the fees per student charged to in -state students, student characteristics and academic programs? Equation 6f was developed to address research question 6f: Does the amount of state need-based financial grant aid received by students at public institutions differ significantly from the amount 
of state need-based financial grant aid receive by students at private institutions? Equation 7a addresses research question number 7a: Is there a relationship between the amount of federal grants, veteran, and tax benefits received per student at public institutions, the amount of tuition and fees paid per student, student characteristics, and the economic and political characteristics of the states? Equation $7 \mathrm{~b}$ addresses research question $7 \mathrm{~b}$ : Is there a relationship between the amount of federal grants, veteran, and tax benefits received per student, the amount of tuition and fees paid per student, student characteristics, and the economic and political characteristics of the states? Equation 7c was developed to address research question 7c: Does the amount of federal grants, veterans, and tax benefits received per student at public institutions differ from the amount of federal grants, veteran, and tax benefits received per student at private institutions? Equation 6a: $\mathrm{SFPBM}_{\mathrm{i}}=\mathrm{T}_{\mathrm{i}}+\mathrm{SA}_{\mathrm{i}}+\mathrm{SAGI}_{\mathrm{i}}+\mathrm{SR}_{\mathrm{i}}+\mathrm{SG}_{\mathrm{i}}+\mathrm{SPEL}_{\mathrm{i}}+\mathrm{SGPA}_{\mathrm{i}}+\mathrm{SVA}_{\mathrm{i}}+\mathrm{LOC}_{\mathrm{i}}+\mathrm{PROGN}_{\mathrm{i}}$ Equation 6b: $\mathrm{SFPVM}_{\mathrm{i}}=\mathrm{T}_{\mathrm{i}}+\mathrm{SA}_{\mathrm{i}}+\mathrm{SAGI}_{\mathrm{i}}+\mathrm{SR}_{\mathrm{i}}+\mathrm{SG}_{\mathrm{i}}+\mathrm{SPEL}_{\mathrm{i}}+\mathrm{SGPA}_{\mathrm{i}}+\mathrm{SVA}_{\mathrm{i}}+\mathrm{LOC}_{\mathrm{i}}+\mathrm{PROGN}_{\mathrm{i}}$ Equation 6c: SFPBM $<$ SFPVM

Equation 6d: $\mathrm{SFPBN}_{\mathrm{i}}=\mathrm{T}_{\mathrm{i}}+\mathrm{SA}_{\mathrm{i}}+\mathrm{SAGI}_{\mathrm{i}}+\mathrm{SR}_{\mathrm{i}}+\mathrm{SG}_{\mathrm{i}}+\mathrm{SPEL}_{\mathrm{i}}+\mathrm{SGPA}_{\mathrm{i}}+\mathrm{SVA}_{\mathrm{i}}+\mathrm{LOC}_{\mathrm{i}}+\mathrm{PROGN}_{\mathrm{i}}$ Equation 6e: $\mathrm{SFPVN}_{\mathrm{i}}=\mathrm{T}_{\mathrm{i}}+\mathrm{SA}_{\mathrm{i}}+\mathrm{SAGI}_{\mathrm{i}}+\mathrm{SR}_{\mathrm{i}}+\mathrm{SG}_{\mathrm{i}}+\mathrm{SPEL}_{\mathrm{i}}+\mathrm{SGPA}_{\mathrm{i}}+\mathrm{SVA}_{\mathrm{i}}+\mathrm{LOC}_{\mathrm{i}}+\mathrm{PROGN}_{\mathrm{i}}$ Equation 6f: SFPBN $<$ SFPVN

Equation 7a: $\mathrm{FFPB}_{\mathrm{i}}=\mathrm{T}_{\mathrm{i}}+\mathrm{SA}_{\mathrm{i}}+\mathrm{SAGI}_{\mathrm{i}}+\mathrm{SR}_{\mathrm{i}}+\mathrm{SG}_{\mathrm{i}}+\mathrm{SPEL}_{\mathrm{i}}+\mathrm{SGPA}_{\mathrm{i}}+\mathrm{SVA}_{\mathrm{i}}+\mathrm{LOC}_{\mathrm{i}}$ Equation 7b: FFPV $=\mathrm{T}_{\mathrm{i}}+\mathrm{SA}_{\mathrm{i}}+\mathrm{SAGI}_{\mathrm{i}}+\mathrm{SR}_{\mathrm{i}}+\mathrm{SG}_{\mathrm{i}}+\mathrm{SPEL}_{\mathrm{i}}+\mathrm{SGPA}_{\mathrm{i}}+\mathrm{SVA}_{\mathrm{i}}+\mathrm{LOC}_{\mathrm{i}}$ Equation 7c: FFPB < FFPV

SFPBM is the total state merit-based financial grant aid paid to students enrolled at public institutions and SFPVM is the total merit-based state financial grant aid paid to students at private institutions. SFPBN is the total state need-based financial grant aid paid to students enrolled at public institutions and SFPVN is the total need-based state financial grant aid paid to 
students at private institutions. FFPB is the federal financial grant aid per student at public institutions and FFPV is the federal financial grant aid per student at private institutions. $\mathrm{T}$ is the tuition and fee charges per student. The other variables are consistent with those identified for the institutional financial aid equation.

The following table describes the specific equation variables that correspond to the research question categories.

Table 10: Research question categories for equations 6a-7c

\begin{tabular}{|l|l|}
\hline Research Question Categories & Equation Variables \\
\hline Student Characteristics & SA, SAGI, SR, SG, SPEL, SGPA, SVA, LOC, \\
\hline $\begin{array}{l}\text { State Political and Economic } \\
\text { Characteristics }\end{array}$ & CR, STLF, STUR, STTG, DEM \\
\hline Academic Programs & PROGN \\
\hline
\end{tabular}

Imperfections in the higher education markets create significant differences in the cost of education for students who attend public and those who attend private institutions. In addition, differences may exist between the costs for in-state and out-of-state students for both types of schools. The following equations were developed to determine the differences in the costs of education for in-state and out-of state students attending public and private colleges and universities.

Equation 8a addresses research question 8a: Is there a relationship between Tuition and fees minus all grants, veteran, and tax benefits for in-state students enrolled at public institutions and adjusted gross income? Equation $8 \mathrm{~b}$ addresses research question $8 \mathrm{~b}$ : Is there a relationship between Tuition and fees minus all grants, veteran, and tax benefits for in-state students enrolled at private institutions and adjusted gross income? Equation $8 \mathrm{c}$ addresses research question 8c:

Does the amount of tuition and fees minus all grants, veteran, and tax benefits for in-state students at public institutions differ from the amount of tuition and fees minus all grants, 
veteran, and tax benefits for in-state students at private institutions? Equation $8 \mathrm{~d}$ addresses research question $8 \mathrm{~d}$ : Is there a relationship between Tuition and fees minus all grants, veteran, and tax benefits for out-of-state students enrolled at public institutions and adjusted gross income? Equation 8e addresses research question 8e: Is there a relationship between Tuition and fees minus all grants, veteran, and tax benefits for out-of-state students enrolled at private institutions and adjusted gross income? Equation $8 \mathrm{f}$ addresses research question 8f: Does the amount of tuition and fees minus all grants, veteran, and tax benefits for in-state students at public institutions differ from the amount of tuition and fees minus all grants, veteran, and tax benefits for in-state students at private institutions?

Equation 8a: TGVTBPBI $_{\mathrm{i}}=\mathrm{AGI}_{\mathrm{i}}$

Equation 8b: TGVTBPVI $_{\mathrm{i}}=\mathrm{AGI}_{\mathrm{i}}$

Equation 8c:TGVTBPBI $\mathrm{T}_{\mathrm{i}}<\mathrm{TGVTBPVI}_{\mathrm{i}}$

Equation 8d:TGVTBPBO ${ }_{\mathrm{i}}=\mathrm{AGI}_{\mathrm{i}}$

Equation 8e:TGVTBPVO ${ }_{\mathrm{i}}=\mathrm{AGI}_{\mathrm{i}}$

Equation 8f:TGVTBPBO ${ }_{\mathrm{i}}<\mathrm{TGVTBPVO}_{\mathrm{i}}$

TGVTBPBI $_{i}$, TGVTBPVI $_{i}$, TGVTBPBO $_{i}$, TGVTBPVO $_{i}$ are the variables for total grants, veterans, and tax benefits for in-state students at public institution; total grants, veterans, and tax benefits for in-state students at private institutions, total grants, veterans, and tax benefits for out-of-state students at public institutions; total grants, veterans, and tax benefits for out-of-state students at private institutions, respectively.

The following econometric equation represents the combined markets which public higher education institutions operate within: 
$\mathrm{TR}_{\mathrm{i}}=\mathrm{SE}_{\mathrm{i}}+\mathrm{CC}_{\mathrm{i}}+\mathrm{CR}_{\mathrm{i}}+\mathrm{DEPRPB}_{\mathrm{i}}+\mathrm{DEPRPV}_{\mathrm{i}}+\mathrm{PUB}_{\mathrm{i}}+\mathrm{PROGI}_{\mathrm{i}}+\mathrm{PROGN}_{\mathrm{i}}+\mathrm{R}_{\mathrm{i}}+2 \mathrm{Y}_{\mathrm{i}}+\mathrm{DEM}_{\mathrm{i}}+$ $\mathrm{STAT}_{\mathrm{i}}+\mathrm{T}_{\mathrm{i}}+\mathrm{SA}_{\mathrm{i}}+\mathrm{SAGI}_{\mathrm{i}}+\mathrm{SR}_{\mathrm{i}}+\mathrm{SG}_{\mathrm{i}}+\mathrm{SPEL}_{\mathrm{i}}+\mathrm{SGPA}_{\mathrm{i}}+\mathrm{SVA}_{\mathrm{i}}+\mathrm{LOC}_{\mathrm{i}}+\mathrm{STLF}_{\mathrm{i}}+\mathrm{STUR}_{\mathrm{i}}+$ STTG $_{\mathrm{i}}$

The combined revenues are represented by the variable $\mathrm{TR}_{\mathrm{i}}$. It appears that all of the markets involve direct relationships between the consumer and provider except for the market pertaining to state appropriations. Transactions between students and schools, donors, and schools and students and governmental financial aid providers normally are the result of informed decisions and direct agreements. Donors who do not specify the purpose of their contribution would be an exception.

State appropriations typically fund general operating expenses and do not target students with certain characteristics. Furthermore, appropriations have an indirect effect on the level of tuition and fees. The resulting bargain tuition levels may provide superfluous subsidies to some segments of a state's population. If the relationship between appropriations, student fees, and financial aid is not addressed by a state government, the intended human capital development outcomes may not be realized.

For the purposes of this study, total revenues included tuition and fees net of financial aid, state appropriations, governmental grants and contracts, and contributions. Revenues from auxiliary enterprises, non-operating revenues, and other revenues were excluded. It must be noted that tuition and fee revenues often include capital fees for the retirement of bonded indebtedness. These fees are not used directly for instruction, research or administrative purposes. 


\section{Research Design}

As stated in the introduction, the purpose of this study is to determine if the difference between market rates for net tuition and fees and the net tuition and fees paid at public institutions is greater for affluent families than middle and lower income families. The net tuition is defined as the total tuition and fees less financial aid grants, tax benefits and veterans' benefits. Because private institutions' tuition rates are not subsidized by state appropriations, they provide the best estimate of the true market rate for tuition and fees. This study will assume that the tuition and fee rates for private institutions reflect the market rates. To perform the study, it was necessary to isolate the markets served by higher education. The econometric theory for higher education developed in chapter two provided a framework for the analysis of the markets that are served by colleges and universities. Through the use of this theory, the markets for instructional services, human capital development, contributions and student characteristics were analyzed separately. The relationships among markets must be understood to determine if they are efficient.

A correlational study of cross sectional data was performed to compare the economic characteristics of the private and public higher education markets. Although longitudinal data may be useful for the study of contributions, the relationships between markets may be better understood through the use of current data. The utility of data collected before 1991 may be limited because generally accepted accounting principles for colleges and universities changed substantially in 2001. For example, depreciation expenses were not calculated for public institutions prior to the principles change. Because depreciation has been identified as a possible determinant in several markets, recent data were needed for the study. 


\section{Population and Sample}

This study utilized data from NPSAS: 04, IPEDS data from fiscal year 2004, the U.S.

Census, the Bureau of Labor Statistics, the National Association of State Universities and Land Grant Colleges, Philanthropic Research, Inc., and the National Conference of State Legislatures were utilized. The NPSAS: 04 study was used to gather information about students in higher education. The other data sources supplied data regarding institutions and their economic environments.

The NPSAS: 04 study provides data about how students and their families pay for postsecondary higher education. It is conducted as a component of the 2004 National Study of Faculty and Students. Included in its target population are all students enrolled in Title IV eligible postsecondary education institutions from July 1, 2003 through June 20, 2004.

The NPSAS: 04 target population consists of all eligible students enrolled at any time between July 1, 2003 and June 30, 2004 in postsecondary institutions in the United States or Puerto Rico which had signed Title IV participation agreements with the U.S. Department of Education making them eligible for the federal student aid programs (Title IV institutions). NPSAS: 04 is based on a nationally representative sample of all students (aided and nonaided) in those institutions. The institutions sampled represented all types and levels of postsecondary institutions in the United States, including public, private forprofit, and private not-for-profit institutions, at the 4-year, 2-year, and less-than-2year levels. In the institutional sample, 1,670 institutions were selected. Of these, 1,630 were determined to be eligible for NPSAS: 04. (Caminole, Siegel, Dudley, Roe, \& Gilligan, 2006)

Of the 1,630 institutions eligible for inclusion in the NPSAS: 04, 1,360 provided enrollment lists. Approximately 109,210 students were included in the sample. The sample included undergraduate, graduate, and professional students. Of these students, 101,010 were determined to be eligible for the study. Students were not eligible if they were also enrolled in a high school or if they were enrolled to obtain a General Equivalency Diploma (GED). They were 
also ineligible if they dropped out before they would qualify for a refund or if they paid tuition to more than one institution. Students who did not enroll for credit were not eligible. The study collected data from multiple sources. In addition to student interviews and data from institutions' student records, information was also collected from the Central Processing System (CPS) for federal financial aid applicants U.S. Census Bureau's Current Population Survey and the National Student Loan Data System. About 90,750 students were determined to have the required data to be included in the study. Of these students, 62,220 completed the student interview portion of the study for the NCES.

To attain a representative sample for the study, stratified sampling techniques were used. Participating institutions were selected from the population of schools that responded to the fiscal year 2001 IPEDS survey. The schools were stratified by institutional type of control, institutional level, highest level of offerings, Carnegie classification, and state. A probabilities proportional to size sample was selected totaling 1,630 institutions. The sample was later freshened with new data from the 2002 IPEDS survey. From a population of newly created or eligible institutions, thirty institutions were added. Of the original 109,210 students included in the sample, approximately 24,470 undergraduate students were enrolled in public 4-year institutions and 15,210 were enrolled in private institutions. Public 4-year institutions enrolled 7,440 graduate and first-professional students in the sample and 4,500 graduate and first professional students were enrolled in private-non-profit-four-year-institutions. Of the students included in the sample, 30,400 of the students enrolled in public 4-year institutions and 18,600 of the students enrolled in private 4-year schools were eligible to participate. From this sample, 21,420 students from public 4-year schools and 13,280 students enrolled in private 4-year institutions completed the survey. 
The NCES identified 6,706 institutions that were eligible for the study. This universe included 421 public 4-year schools and 934 private four-year schools. Of the 1,670 schools selected for the sample, 170 were public 4-year institutions and 140 were private 4 -year institutions. The NPSAS:04 sample data are displayed in Table 11.

Table 11 NPSAS:04 Sample data

\begin{tabular}{|l|r|r|r|r|}
\hline & Public & $\begin{array}{l}\text { Private } \\
\text { non- } \\
\text { profit } \\
\text { 4-year }\end{array}$ & $\begin{array}{c}\text { Other } \\
\text { Institutions }\end{array}$ & Total \\
\hline $\begin{array}{l}\text { Total } \\
\text { Institutions }\end{array}$ & 421 & 934 & 5,351 & 6,706 \\
\hline $\begin{array}{l}\text { Eligible } \\
\text { Institutions }\end{array}$ & 130 & 230 & 1,310 & 1,670 \\
\hline $\begin{array}{l}\text { Participating } \\
\text { Institutions }\end{array}$ & 130 & 230 & 1,270 & 1,630 \\
\hline $\begin{array}{l}\text { Student } \\
\text { Population }\end{array}$ & 31,550 & 19,670 & 57,990 & 109,210 \\
\hline $\begin{array}{l}\text { Student } \\
\text { Sample }\end{array}$ & 31,550 & 19,670 & 57,990 & 109,210 \\
\hline $\begin{array}{l}\text { Number of } \\
\text { eligible } \\
\text { participants }\end{array}$ & 30,500 & 18,890 & 51,620 & 101,010 \\
\hline $\begin{array}{l}\text { Participants } \\
\text { with } \\
\text { adequate } \\
\text { data }\end{array}$ & 28,760 & 18,060 & 43,930 & 90,750 \\
\hline $\begin{array}{l}\text { Number } \\
\text { who } \\
\text { completed } \\
\text { survey }\end{array}$ & 21,420 & 13,280 & 27,520 & 62,220 \\
\hline $\begin{array}{l}\text { Sample } \\
\text { selected for } \\
\text { this study }\end{array}$ & 18,772 & 10,893 & & \\
\hline
\end{tabular}

The Data Analysis System (DAS) created by the National Center for Education Statistics was used to perform statistical analysis of NPSAS: 04 data. Because the NPSAS: 04 sample is 
stratified, the balanced repeated replications technique (BRR) is used by this system to perform regression analysis. This method is a sample reuse method that is used to perform variance analysis for stratified, multi-stage samples. "The term reuse refers to a procedure in which variance estimation is based on repeated utilization of the sampled data set that itself is obtained as a single sample from the population" (Lehtonen \& Pahkinen, 2004, p. 148). The DAS uses 64 replications of the samples (Caminole et al., 2006).

Because a stratified, multistage sample was used for the study, the DAS performs a weighted least squares (WLS) calculation. To use the WLS method, weights are applied to the variables to offset the clustering effects ((Lehtonen \& Pahkinen, 2004). The DAS also provides the Wald test statistic of goodness of fit. This statistic accounts for intra-cluster correlation (Lehtonen \& Pahkinen, 2004).

In addition to the NPSAS: 04, this author's study also utilized IPEDS data. All Title IV eligible institutions that are open to the public are required by the Federal Government to complete the annual IPEDS survey. The completion of the survey by other postsecondary schools is optional. The survey includes the following components, Institutional Characteristics, Completions, Enrollment, Graduation Rates, Student Financial Aid, Employees by Assigned Position, Fall Staff, Salaries, and Finance.

From the IPEDS survey data, public four-year institutions were selected. Tribal colleges were excluded because of their unique financing characteristics. The study included 519 public and 882 private institutions. These schools were selected from the 6,916 institutions included in the 2004 IPEDS survey. Only institutions located in the 50 states that were eligible for federal Title IV aid and were classified by the Carnegie Foundation in the following categories were included in the study: 


\begin{abstract}
Baccalaureate Colleges--General
Baccalaureate Colleges--Liberal Arts,

Baccalaureate/Associates Colleges

Doctoral/Research Universities-Extensive,

Doctoral/Research Universities_-Intensive,

Masters Colleges and Universities I,

Masters Colleges and Universities II.
\end{abstract}

The IPEDS sample data are displayed in Table 12.

Table 12: IPEDS Sample Data

\begin{tabular}{|l|r|r|}
\hline & Population & \multicolumn{1}{l|}{ Sample } \\
\hline Public 4-year & 662 & 519 \\
\hline $\begin{array}{l}\text { Private non-profit 4- } \\
\text { year }\end{array}$ & 1,672 & 882 \\
\hline Other Institutions & 4,582 & \\
\hline Total & 6,916 & 1,401 \\
\hline
\end{tabular}

The data for the number of high school graduates by state were obtained from the NCES Common Core of Data. The U.S Census Bureau was the source for the per-capita tax revenue data. The political composition of the state legislatures was obtained from the National Conference of State Legislatures and contributions information was obtained from Philanthropic Research, Inc.

\title{
Data Analysis
}

The information obtained from the data sources was used to test the econometric models. The variables for the econometric equations are listed in Table A1 of Appendix A. The data selection criteria used for the IPEDS variables are described in Appendix B. In Appendix C, the 
definitions for the IPEDS variables that were used to calculate the several dissertation variables are provided. In Appendix D, the data sources used by NCES for the NPSAS: 04 study are described. The definitions and pertinent statistical data for all variables are provided in Appendix E.

To ascertain the values of the parameters of the econometric equations developed in the first section of this chapter, it was necessary to estimate their values. Because the equations are stochastic, rather than deterministic, a disturbance or error parameter is included. This parameter represents the other factors influencing the relationships among the parameters that have been identified. For example, an infinite number of chance events may influence the economic model. In addition, measurement errors may exist because it is difficult to find variables that accurately reflect the factors influencing the dependent variable. Finally, the unpredictability of human behavior may cause difficulty in obtaining accurate estimates of the parameters' values (Kennedy, 1998, pp. 2-3).

The theory developed in chapter three was used as a foundation for the specification of the equations' parameters. If a parameter's correlation was not significant, it was determined to be a misspecification. Parameters were tested simultaneously to the greatest extent possible (Kennedy, 1998, p. 77).

Kennedy (1998, pp. 43-44) developed five assumptions regarding econometric models. The first assumption is that the model is a linear equation consisting of a specific set of independent variables, plus a disturbance term. Violations of this assumption could result in the omission of important parameters. In addition, the relationship among the variables may not be linear and the parameters may not remain the same during the time period for the test. 
The second assumption is that the expected value of the disturbance term is zero. A violation of this term could result in a biased intercept problem.

The third assumption is that no correlation exists among the disturbance terms and that they all have the same variance. Violations of this assumption could result in heteroskedasticity and autocorrelation of the disturbances.

The fourth assumption of the model is that repeated observations of the independent variables will produce the same values. Violations of this assumption may be a result of errors in measuring the independent variables. In addition, autoregression could occur if the researcher used an independent variable that is an older value of the dependent variable. Simultaneous equations may exist if there are multiple concurrent relationships among the variables.

The final assumption is that the number of observations exceeds the number of independent variables and that there are no exact relationships between the independent variables. This assumption is violated if there is a linear relationship between two or more variables in the sample.

For the purposes of this study, an assumption was made that private non-profit institutions operate in markets that best reflect the actual supply and demand for higher education and student characteristics. The economic characteristics of these institutions are not distorted by the existence of significant levels of state or local appropriations. The market characteristics within which public and private nonprofit institutions operate were compared.

The influence of perceived quality was also recognized as a factor that affects the net price structure of the markets. Because percentages of students admitted and enrolled are perceived to be indicators of quality, the data were analyzed by institutions' selectivity. 
Institutions were also analyzed by level of offering because the identity of an institution as a baccalaureate or graduate degree granting school has some bearing on market prices.

To determine the total excess subsidies to affluent families by region, the percentage of students by income level and institutional selectivity were estimated from the NPSAS: 04 data. In addition, the full time equivalent enrollments for each region were calculated from the IPEDS data. The difference between the student budget minus all grants, veteran and tax benefits for each region, level of selectivity, and income level was multiplied by the in-state full-time equivalent enrollments for each region.

\section{Summary}

The market dynamics of public higher education can be better understood by comparing the economic flows of public schools with their private counterparts. Consequently, the data samples for this study were segregated by type of institution. Although significant differences exist between public and private schools, they compete for the same students.

Multiple regression equations were utilized to determine if the parameters identified in the first section of this chapter were significantly related to the dependent variables. Because the information from NPSAS: 04 was accumulated using stratified sampling techniques, a balanced repeated replication regression analysis was performed for these data. 


\section{CHAPTER FOUR}

\section{Results}

This study examined economic characteristics of higher education to determine if governmental expenditures for human capital development in higher education markets are allocated efficiently. Data from 1,401 institutions of higher learning and 29,665 students were analyzed to answer 36 research questions.

Research question 1a: Is there a statistically significant relationship between the amount of tuition and fees per student charged to in-state students by public institutions, institutional characteristics, and the economic and political characteristics of the states?

Research question 1a relates to Hypothesis 1a, that no statistically significant relationship exists between the amount of tuition and fees per student charged to in-state students by public institutions, institutional characteristics, and the economic and political characteristics of the states.

As described in Chapter 3, the Equation 1a relates to Research Question 1a and Hypothesis 1a: $\mathrm{TPBI}_{\mathrm{i}}=\mathrm{SE}_{\mathrm{i}}+\mathrm{CC}_{\mathrm{i}}+\mathrm{CR}_{\mathrm{i}}+\mathrm{DEM}_{\mathrm{i}}+\mathrm{DEPRPB}_{\mathrm{i}}$

The coefficient data for this equation are displayed in Table 13. Alpha was set at .05 for all calculations. All of the independent variables are significant because their $t$ values exceeded the computed test statistic. The critical value for a .05 level of significance and 445 degrees of freedom is 1.96. All of the $t$ values exceed this statistic. The Pearson product-moment correlation (r) coefficient was .395. Because the significance number for the equation was less than .01, the $r$ statistic is significant. The coefficient of determination was .156. From this statistic, we may conclude that 15.6 percent of the variance in public in-state tuition is explained by the independent variables in this equation. The $F$ statistic for the analysis of variance (ANOVA) 
was 16.422 , indicating that variances among the sample data for each variable exceeded the variance within the sample data for each variable.

To determine if collinear relationships exist among the independent variables, variable inflation factors (VIF) were computed. For each variable, the VIF was slightly above 1 and the corresponding tolerance levels were slightly below 1 , indicating no significant collinearity problems.

Table 13: Equation 1a coefficients

\begin{tabular}{|c|c|c|c|c|c|c|c|}
\hline & \multicolumn{2}{|c|}{$\begin{array}{l}\text { Unstandardized } \\
\text { Coefficients }\end{array}$} & \multirow{2}{*}{$\begin{array}{c}\text { Standardized } \\
\text { Coefficients } \\
\text { Beta } \\
\end{array}$} & \multirow[b]{2}{*}{$t$} & \multirow[b]{2}{*}{ Sig. } & \multicolumn{2}{|c|}{$\begin{array}{c}\text { Collinearity } \\
\text { Statistics }\end{array}$} \\
\hline & B & $\begin{array}{l}\text { Std. } \\
\text { Error }\end{array}$ & & & & Tolerance & VIF \\
\hline (Constant) & 5221.991 & 551.208 & & 9.474 & .001 & & \\
\hline $\begin{array}{l}\text { Selectivity of } \\
\text { the institution } \\
\text { (SE) }\end{array}$ & -976.912 & 407.833 & -.109 & -2.395 & .017 & .922 & 1.085 \\
\hline $\begin{array}{l}\text { Carnegie } \\
\text { Foundation } \\
\text { Classification } \\
\text { (CC) }\end{array}$ & -158.857 & 47.635 & -.146 & -3.335 & .001 & .984 & 1.016 \\
\hline $\begin{array}{l}\text { Per capita tax } \\
\text { revenue for } \\
\text { the state in } \\
\text { which the } \\
\text { school is } \\
\text { operated (CR) }\end{array}$ & .215 & .065 & .147 & 3.283 & .001 & .951 & 1.052 \\
\hline $\begin{array}{l}\text { Political } \\
\text { power in the } \\
\text { legislature } \\
\text { (DEM) }\end{array}$ & -14.010 & 5.690 & -.113 & -2.462 & .014 & .905 & 1.105 \\
\hline $\begin{array}{l}\text { Annual } \\
\text { depreciation } \\
\text { expense per } \\
\text { student } \\
\text { (DEPRPB) }\end{array}$ & 1.748 & .268 & .287 & 6.530 & .001 & .983 & 1.017 \\
\hline
\end{tabular}


Collinearity Diagnostics are displayed in Table 14. Because no two variables within a dimension have variance proportions in excess of .50 and are associated with a large condition index, the level of collinearity is acceptable.

Table 14: Equation 1a collinearity diagnostics

\begin{tabular}{|l|l|l|l|l|l|l|}
\hline Dimension & 1 & 2 & 3 & 4 & 5 & 6 \\
\hline Eigenvalue & 4.724 & .989 & .165 & .073 & .038 & .011 \\
\hline Condition Index & 1.00 & 2.185 & 5.355 & 8.032 & 11.201 & 20.449 \\
\hline Constant & .000 & .000 & .000 & .000 & .000 & 1.00 \\
\hline Selectivity of the institution & .00 & .00 & .010 & .44 & .060 & .490 \\
\hline $\begin{array}{l}\text { Carnegie Foundation } \\
\text { Classification (CC) }\end{array}$ & .010 & .000 & .980 & .000 & .000 & .010 \\
\hline $\begin{array}{l}\text { Per capita tax revenue for the } \\
\text { state in which the school is } \\
\text { operated (CR) }\end{array}$ & .000 & .000 & .010 & .030 & .670 & .290 \\
\hline $\begin{array}{l}\text { Political power in the } \\
\text { legislature (DEM) }\end{array}$ & .000 & .000 & .020 & .230 & .460 & .290 \\
\hline $\begin{array}{l}\text { Annual depreciation expense } \\
\text { per student (DEPRPB) }\end{array}$ & .000 & .980 & .010 & .000 & .000 & .010 \\
\hline
\end{tabular}

The correlations for this equation are displayed in Table 15.

Table 15: Equation 1a correlations

\begin{tabular}{|c|c|c|c|c|c|}
\hline & & $\begin{array}{l}\text { In-state } \\
\text { tuition and } \\
\text { fees per } \\
\text { student } \\
\text { (TPBI) }\end{array}$ & $\begin{array}{l}\text { Selectivity } \\
\text { of the } \\
\text { institution } \\
\text { (SE) }\end{array}$ & $\begin{array}{c}\text { Carnegie } \\
\text { Foundation } \\
\text { Classification } \\
\text { (CC) }\end{array}$ & $\begin{array}{l}\text { Per capita tax } \\
\text { revenue for the } \\
\text { state in which } \\
\text { the school is } \\
\text { operated (CR) }\end{array}$ \\
\hline \multirow{3}{*}{$\begin{array}{l}\text { In-state tuition } \\
\text { and fees per } \\
\text { student (TPBI) }\end{array}$} & Correlation & 1 & -.128 & -.167 & .128 \\
\hline & Sig. (1-tailed) & & .003 & .001 & .003 \\
\hline & $\mathrm{N}$ & 451 & 451 & 451 & 451 \\
\hline \multirow{3}{*}{$\begin{array}{l}\text { Selectivity of } \\
\text { the institution } \\
\text { (SE) }\end{array}$} & Correlation & -.128 & 1 & .056 & -.119 \\
\hline & Sig. (1-tailed) & .003 & & .118 & .006 \\
\hline & $\mathrm{N}$ & 451 & 451 & 451 & 451 \\
\hline \multirow{2}{*}{$\begin{array}{l}\text { Carnegie } \\
\text { Foundation }\end{array}$} & Correlation & -.167 & .056 & 1 & .077 \\
\hline & Sig. (1-tailed) & .001 & .118 & & .052 \\
\hline
\end{tabular}




\begin{tabular}{|c|c|c|c|c|c|}
\hline $\begin{array}{l}\text { Classification } \\
\text { (CC) }\end{array}$ & $\mathrm{N}$ & 451 & 451 & 451 & 451 \\
\hline \multirow{3}{*}{$\begin{array}{l}\text { Per capita tax } \\
\text { revenue for } \\
\text { the state in } \\
\text { which the } \\
\text { school is } \\
\text { operated (CR) }\end{array}$} & Correlation & .128 & -.119 & 0.077 & 1 \\
\hline & Sig. (1-tailed) & .003 & .006 & 0.052 & \\
\hline & $\mathrm{N}$ & 451 & 451 & 451 & 451 \\
\hline \multirow{3}{*}{$\begin{array}{l}\text { Political } \\
\text { power in the } \\
\text { legislature } \\
\text { (DEM) }\end{array}$} & Correlation & -.078 & -.247 & 0.032 & .195 \\
\hline & Sig. (1-tailed) & .049 & .001 & 0.247 & .001 \\
\hline & $\mathrm{N}$ & 451 & 451 & 451 & 451 \\
\hline \multirow{3}{*}{$\begin{array}{l}\text { Annual } \\
\text { depreciation } \\
\text { expense per } \\
\text { student } \\
\text { (DEPRPB) }\end{array}$} & Correlation & .313 & -.076 & -0.076 & .005 \\
\hline & Sig. (1-tailed) & .001 & .053 & 0.053 & .460 \\
\hline & $\mathrm{N}$ & 451 & 451 & 451 & 451 \\
\hline
\end{tabular}

Table 15: Equation 1a correlations (continued)

\begin{tabular}{|c|c|c|c|}
\hline & & $\begin{array}{l}\text { Political } \\
\text { power in } \\
\text { the } \\
\text { legislature } \\
\text { (DEM) }\end{array}$ & $\begin{array}{c}\text { Annual } \\
\text { depreciation } \\
\text { expense per } \\
\text { student } \\
\text { (DEPRPB) }\end{array}$ \\
\hline \multirow{3}{*}{$\begin{array}{l}\text { In-state } \\
\text { tuition and } \\
\text { fees per } \\
\text { student } \\
\text { (TPBI) }\end{array}$} & Correlation & -.078 & .313 \\
\hline & Sig. (1-tailed) & .049 & .001 \\
\hline & $\mathrm{N}$ & 451 & 451 \\
\hline \multirow{3}{*}{$\begin{array}{l}\text { Selectivity } \\
\text { of the } \\
\text { institution } \\
\text { (SE) }\end{array}$} & Correlation & -.247 & -.076 \\
\hline & Sig. (1-tailed) & .001 & .053 \\
\hline & $\mathrm{N}$ & 451 & 451 \\
\hline \multirow{3}{*}{$\begin{array}{l}\text { Carnegie } \\
\text { Foundation } \\
\text { Classificatio } \\
\mathrm{n}(\mathrm{CC})\end{array}$} & Correlation & .032 & -.076 \\
\hline & Sig. (1-tailed) & .247 & .053 \\
\hline & $\mathrm{N}$ & 451 & 451 \\
\hline \multirow{3}{*}{$\begin{array}{l}\text { Per capita } \\
\text { tax revenue } \\
\text { for the state } \\
\text { in which the } \\
\text { school is } \\
\text { operated }\end{array}$} & Correlation & .195 & .005 \\
\hline & Sig. (1-tailed) & .001 & .460 \\
\hline & $\mathrm{N}$ & 451 & 451 \\
\hline
\end{tabular}




\begin{tabular}{|c|c|c|c|}
\hline$(\mathrm{CR})$ & & & \\
\hline \multirow{3}{*}{$\begin{array}{l}\text { Political } \\
\text { power in the } \\
\text { legislature } \\
\text { (DEM) }\end{array}$} & Correlation & 1 & -.056 \\
\hline & Sig. (1-tailed) & & .118 \\
\hline & $\mathrm{N}$ & 451 & 451 \\
\hline \multirow{3}{*}{$\begin{array}{l}\text { Annual } \\
\text { depreciation } \\
\text { expense per } \\
\text { student } \\
\text { (DEPRPB) }\end{array}$} & Correlation & -.056 & 1 \\
\hline & Sig. (1-tailed) & .118 & \\
\hline & $\mathrm{N}$ & 451 & 451 \\
\hline
\end{tabular}

Significant relationships were identified between in-state tuition and fees per student charged to in-state students and the selectivity of institutions, their Carnegie Foundation classifications, the per-capita tax revenue for the states in which they were operated, the political power in the legislature and the institutions' annual depreciation expense per student. These relationships are represented by the following econometric equation:

$$
\mathrm{TPBI}_{\mathrm{i}}=-976.912 \mathrm{SE}_{\mathrm{i}}-158.857 \mathrm{CC}_{\mathrm{i}}+.215 \mathrm{CR}_{\mathrm{i}}-14.010 \mathrm{DEM}_{\mathrm{i}}+1.748 \mathrm{DEPRPB}_{\mathrm{i}}+
$$

5221.991

Research Question 1b: Is there a statistically significant relationship between the amount of tuition and fees per student charged to in-state students by private institutions, institutional characteristics, and the economic and political characteristics of the states?

Research Question $1 \mathrm{~b}$ relates to Hypothesis $1 \mathrm{~b}$, that no statistically significant relationship exists between the amount of tuition and fees per student charged to in-state students by private institutions, institutional characteristics, and the economic and political characteristics of the states.

As described in Chapter 3, the Equation 1b relates to Research Question 1b and Hypothesis $1 \mathrm{~b}: \mathrm{TPVI}_{\mathrm{i}}=\mathrm{SE}_{\mathrm{i}}+\mathrm{CC}_{\mathrm{i}}+\mathrm{CR}_{\mathrm{i}}+\mathrm{DEM}_{\mathrm{i}}+\mathrm{DEPRPV}_{\mathrm{i}}$ 
The significance values for the independent variables of this equation are displayed in Table 16. All of the variables are significant except for Political Power in the legislature. Alpha was set at .05 for all calculations.

Table 16: Equation 1b coefficients

\begin{tabular}{|c|c|c|c|c|c|}
\hline & \multicolumn{2}{|c|}{$\begin{array}{c}\text { Unstandardized } \\
\text { Coefficients } \\
\end{array}$} & \multirow{2}{*}{$\begin{array}{c}\text { Standardized } \\
\text { Coefficients } \\
\text { Beta } \\
\end{array}$} & \multirow[b]{2}{*}{$t$} & \multirow[b]{2}{*}{ Sig. } \\
\hline & B & Std. Error & & & \\
\hline (Constant) & 13117.049 & 1374.613 & & 9.542 & .001 \\
\hline $\begin{array}{l}\text { Selectivity of the } \\
\text { institution (SE) }\end{array}$ & -2702.347 & 1012.259 & -.087 & -2.670 & .008 \\
\hline $\begin{array}{l}\text { Carnegie Foundation } \\
\text { Classification (CC) }\end{array}$ & -654.373 & 109.017 & -.181 & -6.002 & .001 \\
\hline $\begin{array}{l}\text { Per capita tax revenue } \\
\text { for the state in which } \\
\text { the school is operated } \\
\text { (CR) }\end{array}$ & 1.345 & .190 & .221 & 7.079 & .001 \\
\hline $\begin{array}{l}\text { Political power in the } \\
\text { legislature (DEM) }\end{array}$ & 10.431 & 13.560 & .024 & .769 & .442 \\
\hline $\begin{array}{l}\text { Annual depreciation } \\
\text { expense per student } \\
\text { (DEPRPV) }\end{array}$ & 1.382 & .113 & .406 & 12.213 & .001 \\
\hline
\end{tabular}

Because the variable Political power in the legislature is operated is not significant, a second regression equation was calculated without this variable. The coefficients for this equation are displayed in Table 17. All of the correlations between the independent variables and the dependent variable were statistically significant. The Pearson product-moment correlation $(r)$ coefficient was .600. Because the significance number for this equation was less than .01, the $r$ statistic is significant. The coefficient of determination was .360. From this statistic, we may conclude that 36 percent of the variance in public in-state tuition is explained by the independent variables in this equation. The $F$ statistic for the ANOVA was 110.196, indicating that variances among the sample data for each variable exceeded the variance within the sample data for each 
variable. The critical value for a .05 level of significance and 785 degrees of freedom is \pm 1.96 .

All of the variables are significant because their $t$ values exceed this critical value. To determine if collinear relationships exist among the independent variables, variable inflation factors (VIF) were computed. For each variable, the VIF was slightly above 1 and the corresponding tolerance levels were slightly below 1 , indicating no significant collinearity problems.

Table 17: Equation 1b second calculation coefficients

\begin{tabular}{|l|c|c|c|c|c|c|c|}
\hline & \multicolumn{2}{|c|}{$\begin{array}{c}\text { Unstandardized } \\
\text { Coefficients }\end{array}$} & $\begin{array}{l}\text { Standardized } \\
\text { Coefficients }\end{array}$ & & \multicolumn{2}{|c|}{$\begin{array}{c}\text { Collinearity } \\
\text { Statistics }\end{array}$} \\
\hline & B & Std. Error & Beta & $t$ & Sig. & Tolerance & VIF \\
\hline (Constant) & 13365.769 & 1283.664 & & 10.412 & .001 & & \\
\hline $\begin{array}{l}\text { Selectivity of } \\
\text { the institution } \\
\text { (SE) }\end{array}$ & -2642.735 & 980.784 & -.086 & -2.695 & .007 & .801 & 1.249 \\
\hline $\begin{array}{l}\text { Carnegie } \\
\text { Foundation } \\
\begin{array}{l}\text { Classification } \\
\text { (CC) }\end{array}\end{array}$ & -666.765 & 107.888 & -.184 & -6.180 & .001 & .917 & 1.091 \\
\hline $\begin{array}{l}\text { Per capita tax } \\
\text { revenue for } \\
\text { the state in } \\
\text { which the } \\
\text { school is } \\
\text { operated (CR) }\end{array}$ & 1.400 & .175 & .230 & 7.985 & .001 & .981 & 1.019 \\
\hline $\begin{array}{l}\text { Annual } \\
\text { depreciation } \\
\text { expense per } \\
\text { student } \\
\text { (DEPRPV) }\end{array}$ & 1.393 & .112 & .409 & 12.435 & .001 & .756 & 1.323 \\
\hline
\end{tabular}

The Collinearity Diagnostics for this equation are displayed in Table 18. Because none of the variance proportions in any dimension exceed .5 and the condition indexes are not relatively large, these variables are not significantly correlated with each other. 
Table 18: Equation 1b collinearity diagnostics

\begin{tabular}{|l|l|l|l|l|l|}
\hline Dimension & 1 & 2 & 3 & 4 & 5 \\
\hline Eigenvalue & 4.339 & .519 & .090 & .041 & .011 \\
\hline Condition Index & 1.000 & 2.890 & 6.938 & 10.308 & 19.686 \\
\hline Constant & .000 & .000 & .000 & .010 & .980 \\
\hline $\begin{array}{l}\text { Selectivity of the institution } \\
\text { (SE) }\end{array}$ & .000 & .010 & .100 & .650 & .230 \\
\hline $\begin{array}{l}\text { Carnegie Foundation } \\
\text { Classification (CC) }\end{array}$ & .000 & .010 & .800 & .000 & .170 \\
\hline $\begin{array}{l}\text { Per capita tax revenue for the } \\
\text { state in which the school is } \\
\text { operated (CR) }\end{array}$ & .000 & .000 & .040 & .350 & .610 \\
\hline $\begin{array}{l}\text { Annual depreciation expense } \\
\text { per student (DEPRPV) }\end{array}$ & .010 & .630 & .020 & .220 & .120 \\
\hline
\end{tabular}

The correlations for this equation are displayed in Table 19.

Table 19: Equation 1b correlations

\begin{tabular}{|l|l|r|r|r|}
\hline & & $\begin{array}{c}\text { In-state } \\
\text { tuition } \\
\text { and fees } \\
\text { per } \\
\text { student } \\
\text { (TPVI) }\end{array}$ & $\begin{array}{c}\text { Selectivity } \\
\text { of the } \\
\text { institution } \\
\text { (SE) }\end{array}$ & $\begin{array}{c}\text { Carnegie } \\
\text { Foundation } \\
\text { Classification } \\
\text { (CC) }\end{array}$ \\
\hline \multirow{2}{*}{$\begin{array}{l}\text { In-state tuition and } \\
\text { fees per student } \\
\text { (TPVI) }\end{array}$} & Correlation & 1 & -.290 & -.333 \\
\cline { 2 - 5 } & Sig. (1-tailed) & & .001 & .001 \\
\cline { 2 - 5 } $\begin{array}{l}\text { Selectivity of the } \\
\text { institution (SE) }\end{array}$ & Correlation & -.290 & 790 & 790 \\
\cline { 2 - 5 } & Sig. (1-tailed) & .001 & 1 & .127 \\
\cline { 2 - 5 } & $\mathrm{N}$ & 790 & 790 & .001 \\
\hline \multirow{2}{*}{$\begin{array}{l}\text { Carnegie Foundation } \\
\text { Classification (CC) }\end{array}$} & Correlation & -.333 & 0.127 & 790 \\
\cline { 2 - 5 } & Sig. (1-tailed) & .001 & .001 & 1 \\
\cline { 2 - 5 } & $\mathrm{N}$ & 790 & 790 & 790 \\
\hline $\begin{array}{l}\text { Per Capita tax } \\
\text { revenue for the state } \\
\text { in which the school is } \\
\text { operated (CR) }\end{array}$ & Correlation & .280 & .006 & -.128 \\
\cline { 2 - 5 } & Sig. (1-tailed) & .001 & .437 & .001 \\
\cline { 2 - 5 } & $\mathrm{N}$ & 790 & 790 & 790 \\
\hline Annual depreciation & Correlation & .511 & -.445 & -.266 \\
\hline
\end{tabular}




\begin{tabular}{|l|l|r|r|r|}
\hline $\begin{array}{l}\text { expense per student } \\
(\text { DEPRPV }\end{array}$ & Sig. (1-tailed) & .001 & .001 & .001 \\
\cline { 2 - 5 } & $\mathrm{N}$ & 790 & 790 & 790 \\
\hline
\end{tabular}

Table19: Equation 1b correlations (continued)

\begin{tabular}{|c|c|c|c|}
\hline & & $\begin{array}{l}\text { Per capita } \\
\text { tax revenue } \\
\text { for the state } \\
\text { in which the } \\
\text { school is } \\
\text { operated } \\
\text { (CR) }\end{array}$ & $\begin{array}{c}\text { Annual } \\
\text { depreciation } \\
\text { expense per } \\
\text { student } \\
\text { (DEPRPV) }\end{array}$ \\
\hline \multirow{3}{*}{$\begin{array}{l}\text { In-state tuition and } \\
\text { fees per student } \\
\text { (TPVI) }\end{array}$} & Correlation & .280 & .511 \\
\hline & Sig. (1-tailed) & .001 & .001 \\
\hline & $\mathrm{N}$ & 790 & 790 \\
\hline \multirow{3}{*}{$\begin{array}{l}\text { Selectivity of the } \\
\text { institution (SE) }\end{array}$} & Correlation & .006 & -.445 \\
\hline & Sig. (1-tailed) & .437 & .001 \\
\hline & $\mathrm{N}$ & 790 & 790 \\
\hline \multirow{3}{*}{$\begin{array}{l}\text { Carnegie Foundation } \\
\text { Classification (CC) }\end{array}$} & Correlation & -.128 & -.266 \\
\hline & Sig. (1-tailed) & .001 & .001 \\
\hline & $\mathrm{N}$ & 790 & 790 \\
\hline \multirow{3}{*}{$\begin{array}{l}\text { Per Capita tax } \\
\text { revenue for the state } \\
\text { in which the school is } \\
\text { operated (CR) }\end{array}$} & Correlation & 1 & .065 \\
\hline & Sig. (1-tailed) & & .034 \\
\hline & $\mathrm{N}$ & 790 & 790 \\
\hline \multirow{3}{*}{$\begin{array}{l}\text { Annual depreciation } \\
\text { expense per student } \\
\text { (DEPRPV) }\end{array}$} & Correlation & .065 & 1 \\
\hline & Sig. (1-tailed) & .034 & \\
\hline & $\mathrm{N}$ & 790 & 790 \\
\hline
\end{tabular}

Significant relationships exist between the amount of tuition and fees per student charged to in-state students by private institutions and the selectivity of the institutions, their Carnegie Foundation classifications, the per-capita tax revenue for the states in which they are operated, and the annual depreciation expense per student. These relationships are represented by the following econometric equation:

$$
\mathrm{TPVI}_{\mathrm{i}}=-2642.735 \mathrm{SE}_{\mathrm{i}}-666.765 \mathrm{CC}_{\mathrm{i}}+1.400 \mathrm{CR}_{\mathrm{i}}+1.393 \mathrm{DEPRPV}_{\mathrm{i}}+13365.769
$$


Research Question 1c: Does the amount of tuition and fees per student charged to instate students at private institutions differ significantly from the in-state tuition charged to instate students at public institutions? Research Question 1c relates to Hypothesis 1c, that tuition and fees per student charged to in-state students by public institutions is less than or equal to the tuition and fees charged to in-state students by private institutions.

As described in Chapter 3, Equation 1c relates to Research Question 1c and Hypothesis 1c:

$$
\mathrm{TPBI} \leq \mathrm{TPVI} .
$$

The results of the means comparison are displayed in Table 20. Because the standard deviation for private institutions exceeds three times the standard deviation of public institutions, the variances of the two sets of data are not homogenous. Levene's Test for Equality of Variances was calculated to detect heterogeneity between the data for public and private institutions. The $F$ statistic for this test was 446.879 , indicating a high level of heterogeneity. The $t$ value for the comparison of the two means was -61.783 for $1,054.212$ degrees of freedom and a significance of less than .01. This indicates that the difference between the two means is significant

Table 20: Equation 1c group statistics

\begin{tabular}{|l|l|c|c|c|c|}
\hline & $\begin{array}{l}\text { Control of } \\
\text { institution }\end{array}$ & $\mathrm{N}$ & Mean & $\begin{array}{c}\text { Std. } \\
\text { Deviation }\end{array}$ & $\begin{array}{c}\text { Std. Error } \\
\text { Mean }\end{array}$ \\
\hline \multirow{2}{*}{$\begin{array}{l}\text { In-state tuition and } \\
\text { fees per student }\end{array}$} & Public (TPBI) & 506 & 4429.460 & 1553.125 & 69.045 \\
\cline { 2 - 6 } & $\begin{array}{l}\text { Private non-profit } \\
\text { (TPVI) }\end{array}$ & 861 & 17420.360 & 5827.704 & 198.608 \\
\hline
\end{tabular}

Research Question 1d: Is there a statistically significant relationship between the amount of tuition and fees per student charged to out-of-state students by public institutions, 


\section{institutional characteristics and the economic and political characteristics of the states?}

Research Question 1d relates to Hypothesis 1d, that no statistically significant relationship exists between the amount of tuition and fees per student charged to out-of-state students by public institutions, institutional characteristics, and the economic and political characteristics of the states.

As described in Chapter 3, the Equation 1d relates to Research Question 1d and Hypothesis 1d: $\mathrm{TPBO}_{\mathrm{i}}=\mathrm{SE}_{\mathrm{i}}+\mathrm{CC}_{\mathrm{i}}+\mathrm{CR}_{\mathrm{i}}+\mathrm{DEM}_{\mathrm{i}}+\mathrm{DEPRPB}_{\mathrm{i}}$

The significance scores for the independent variables of this equation are displayed in Table 21.

All of the variables are significant except for Per capita tax revenue for the state in which the school is operated. Alpha was set at .05 for all calculations.

Table 21: Equation 1d coefficients

\begin{tabular}{|l|r|r|r|r|r|}
\hline & \multicolumn{2}{|c|}{$\begin{array}{c}\text { Unstandardized } \\
\text { Coefficients }\end{array}$} & $\begin{array}{l}\text { Standardized } \\
\text { Coefficients }\end{array}$ & & \\
\hline & \multicolumn{1}{c|}{$\mathrm{B}$} & \multicolumn{1}{c|}{ Std. Error } & \multicolumn{1}{c|}{ Beta } & \multicolumn{1}{c|}{$t$} & \multicolumn{1}{c|}{ Sig. } \\
\hline (Constant) & 17753.954 & 1153.473 & & 15.392 & .001 \\
\hline $\begin{array}{l}\text { Selectivity of the } \\
\text { institution (SE) }\end{array}$ & -3070.228 & 853.443 & -.156 & -3.597 & .001 \\
\hline $\begin{array}{l}\text { Carnegie Foundation } \\
\text { Classification (CC) }\end{array}$ & -888.151 & 99.682 & -.374 & -.8 .910 & .001 \\
\hline $\begin{array}{l}\text { Per capita tax revenue } \\
\text { for the state in which } \\
\text { the school is operated } \\
\text { (CR) }\end{array}$ & .113 & .137 & .035 & .822 & .411 \\
\hline $\begin{array}{l}\text { Political power in the } \\
\text { legislature (DEM) }\end{array}$ & -44.158 & 11.906 & -.162 & -3.709 & .001 \\
\hline $\begin{array}{l}\text { Annual depreciation } \\
\text { expense per student } \\
\text { (DEPRPB) }\end{array}$ & 2.108 & .560 & .158 & 3.764 & .001 \\
\hline
\end{tabular}

Because the variable Per capita tax revenue for the state in which the school is operated is not significant, a second regression equation was calculated without this variable. The coefficients 
for this equation are displayed in Table 22. All of the correlations between the independent variables and the dependent variable were statistically significant. The Pearson product-moment correlation $(r)$ coefficient was .476. Because the significance number for this equation was less than .01, the $r$ statistic is significant. The coefficient of determination was .227. From this statistic, we may conclude that 22.7 percent of the variance in public in-state tuition is explained by the independent variables in this equation. The $F$ statistic for the ANOVA is 32.654 , indicating that variances among the sample data for each variable exceeded the variance within the sample data for each variable. The critical value for a .05 level of significance and 446 degrees of freedom is \pm 1.96 . All of the variables are significant because their $t$ values exceed the critical value. To determine if collinear relationships exist among the independent variables, variable inflation factors (VIF) were computed. For each variable, the VIF is slightly above 1 and the corresponding tolerance levels are slightly below 1 , indicating no significant collinearity problems.

Table 22: Equation 1d second calculation coefficients

\begin{tabular}{|l|c|c|c|c|c|c|c|}
\hline & \multicolumn{2}{|c|}{$\begin{array}{l}\text { Unstandardized } \\
\text { Coefficients }\end{array}$} & $\begin{array}{c}\text { Standardized } \\
\text { Coefficients }\end{array}$ & & & \multicolumn{2}{|c|}{ Collinearity Statistics } \\
\hline & $\mathrm{B}$ & $\begin{array}{c}\text { Std. } \\
\text { Error }\end{array}$ & Beta & $t$ & Sig. & Tolerance & VIF \\
\hline (Constant) & 18252.076 & 981.217 & & 18.601 & .001 & & \\
\hline $\begin{array}{l}\text { Selectivity of } \\
\text { the institution } \\
\text { (SE) }\end{array}$ & -3125.363 & 850.495 & -.159 & -3.675 & .001 & .927 & 1.078 \\
\hline $\begin{array}{l}\text { Carnegie } \\
\text { Foundation } \\
\text { Classification } \\
\text { (CC) }\end{array}$ & -881.773 & 99.344 & -.372 & -8.876 & .001 & .990 & 1.010 \\
\hline $\begin{array}{l}\text { Annual } \\
\text { depreciation } \\
\text { expense per } \\
\text { student } \\
\text { (DEPRPB) }\end{array}$ & 2.115 & .560 & .159 & 3.777 & .001 & .984 & 1.017 \\
\hline $\begin{array}{l}\text { Political } \\
\text { power in the }\end{array}$ & -42.504 & 11.731 & -.156 & -3.623 & .001 & .932 & 1.073 \\
\hline
\end{tabular}


legislature

(DEM)

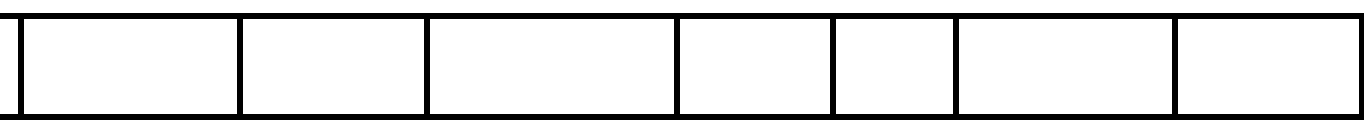

The Collinearity Diagnostics for this equation are displayed in Table 23. Because the variance proportions for Selectivity of the institution and Political power in the legislature exceed .5 and the condition index for dimension 5 is relatively large, these variables are significantly correlated with each other.

Table 23: Equation 1d collinearity diagnostics

\begin{tabular}{|l|l|l|l|l|l|}
\hline Dimension & 1 & 2 & 3 & 4 & 5 \\
\hline Eigenvalue & 3.768 & .989 & .158 & .071 & .014 \\
\hline Condition Index & 1.000 & 1.952 & 4.891 & 7.301 & 16.312 \\
\hline Constant & .000 & .000 & .010 & .000 & .990 \\
\hline Selectivity of the institution (SE) & .000 & .000 & .030 & .380 & .590 \\
\hline Carnegie Foundation Classification (CC) & .010 & .000 & .970 & .000 & .020 \\
\hline Political power in the legislature (DEM) & .000 & .000 & .030 & .370 & .600 \\
\hline $\begin{array}{l}\text { Annual depreciation expense per student } \\
\text { (DEPRPB) }\end{array}$ & .000 & .980 & .010 & .000 & .020 \\
\hline
\end{tabular}

To address the collinearity issue, a third regression was computed without the variable Political power in the legislature. The significance scores for the independent variables of this equation are displayed in Table 24. All of the variables are significant. Alpha was set at .05 for all calculations.

Table 24: Equation 1d third calculation coefficients

\begin{tabular}{|l|c|c|c|c|c|l|l|}
\hline & \multicolumn{2}{|c|}{$\begin{array}{c}\text { Unstandardized } \\
\text { Coefficients }\end{array}$} & $\begin{array}{c}\text { Standardized } \\
\text { Coefficients }\end{array}$ & & \multicolumn{2}{|l|}{$\begin{array}{l}\text { Collinearity } \\
\text { Statistics }\end{array}$} \\
\hline & $\mathrm{B}$ & $\begin{array}{c}\text { Std. } \\
\text { Error }\end{array}$ & Beta & $t$ & Sig. & Tolerance & VIF \\
\hline (Constant) & 15591.039 & 652.790 & & 23.884 & .001 & & \\
\hline
\end{tabular}




\begin{tabular}{|l|r|r|r|r|r|r|l|}
\hline $\begin{array}{l}\text { Selectivity of } \\
\text { the institution } \\
\text { (SE) }\end{array}$ & -2378.458 & 830.500 & -.121 & -2.864 & .004 & .992 & 1.008 \\
\hline $\begin{array}{l}\text { Carnegie } \\
\begin{array}{l}\text { Foundation } \\
\text { Classification } \\
\text { (CC) }\end{array}\end{array}$ & -896.139 & 100.219 & -.378 & -8.942 & .001 & .992 & 1.008 \\
\hline $\begin{array}{l}\text { Annual } \\
\text { depreciation } \\
\text { expense per } \\
\text { student } \\
\text { (DEPRPB }\end{array}$ & 2.268 & .565 & .170 & 4.015 & .001 & .989 & 1.011 \\
\hline
\end{tabular}

The Pearson product-moment correlation $(r)$ coefficient was .452. Because the significance number for this equation was less than .01 , the $r$ statistic is significant. The coefficient of determination $\left(\mathrm{r}^{2}\right)$ was .204 . From this statistic, we may conclude that 20.4 percent of the variance in public out-of-state tuition is explained by the independent variables in this equation. The $F$ statistic for the ANOVA was 38.441, indicating that variances among the sample data for each variable exceeded the variance within the sample data for each variable. The critical value for a .05 level of significance and 450 degrees of freedom is \pm 1.96 . All of the variables are significant because their $t$ values exceed the critical value. To determine if collinear relationships exist among the independent variables, variable inflation factors (VIF) were computed. For each variable, the VIF was slightly above 1 and the corresponding tolerance levels were slightly below 1 , indicating no significant collinearity problems.

The Collinearity Diagnostics for this equation are displayed in Table 25. Because no combination of variance proportions for two or more variables exceed .5 in a dimension, these variables are not significantly correlated with each other. 
Table 25: Equation 1d third calculation collinearity diagnostics

\begin{tabular}{|l|l|l|l|l|}
\hline Dimension & 1 & 2 & 3 & 4 \\
\hline Eigenvalue & 2.839 & .988 & .145 & .027 \\
\hline Condition Index & 1.000 & 1.695 & 4.421 & 10.198 \\
\hline Constant & .010 & .000 & .030 & .960 \\
\hline Selectivity of the institution (SE) & .010 & .000 & .090 & .910 \\
\hline $\begin{array}{l}\text { Carnegie Foundation Classification } \\
\text { (CC) }\end{array}$ & .020 & .000 & .920 & .050 \\
\hline $\begin{array}{l}\text { Annual depreciation expense per } \\
\text { student (DEPRPB) }\end{array}$ & .000 & .980 & .010 & .010 \\
\hline
\end{tabular}

The correlations for this equation are displayed in Table 26.

Table 26: Equation 1d correlations

\begin{tabular}{|c|c|c|c|c|c|}
\hline & & $\begin{array}{c}\text { Out-of-state } \\
\text { tuition and } \\
\text { fees per } \\
\text { student }\end{array}$ & $\begin{array}{l}\text { Selectivity } \\
\text { of the } \\
\text { institution }\end{array}$ & $\begin{array}{c}\text { Carnegie } \\
\text { Foundation } \\
\text { Classification }\end{array}$ & $\begin{array}{c}\text { Annual } \\
\text { depreciation } \\
\text { expense per } \\
\text { student }\end{array}$ \\
\hline \multirow{3}{*}{$\begin{array}{l}\text { Out-of-state } \\
\text { tuition and } \\
\text { fees per } \\
\text { student } \\
\text { (TPBO) }\end{array}$} & Correlation & 1 & -.155 & -.397 & .208 \\
\hline & Sig. (1-tailed) & & .001 & .001 & .001 \\
\hline & $\mathrm{N}$ & & 454 & 454 & 454 \\
\hline \multirow{3}{*}{$\begin{array}{l}\text { Selectivity of } \\
\text { the institution } \\
\text { (SE) }\end{array}$} & Correlation & -.155 & 1 & .055 & -.077 \\
\hline & Sig. (1-tailed) & .001 & & .120 & .051 \\
\hline & $\mathrm{N}$ & 454 & & 454 & 454 \\
\hline \multirow{3}{*}{$\begin{array}{c}\text { Carnegie } \\
\text { Foundation } \\
\text { Classification } \\
(\mathrm{CC}) \\
\end{array}$} & Correlation & -.397 & .055 & 1 & -.076 \\
\hline & Sig. (1-tailed) & .001 & .120 & & .053 \\
\hline & $\mathrm{N}$ & 454 & 454 & & 454 \\
\hline \multirow{3}{*}{$\begin{array}{c}\text { Annual } \\
\text { depreciation } \\
\text { expense per } \\
\text { student } \\
\text { (DEPRPB) }\end{array}$} & Correlation & .208 & -.077 & -.076 & 1 \\
\hline & Sig. (1-tailed) & .001 & .051 & .053 & \\
\hline & $\mathrm{N}$ & 454 & 454 & 454 & \\
\hline
\end{tabular}

The results of the regression analysis indicate that significant relationships exist between the amount of tuition and fees per student charged to out-of-state students by public institutions 
and the selectivity of the institutions, their Carnegie Foundation classification, and the annual depreciation expense per student. These relationships are represented by the following econometric equation:

$\mathrm{TPBO}_{\mathrm{i}}=-2378.458 \mathrm{SE}_{\mathrm{i}}-896.139 \mathrm{CC}_{\mathrm{i}}+2.268 \mathrm{DEPRPB}_{\mathrm{i}}+15591.039$

\section{Research Question 1e: Is there a statistically significant relationship between the} amount of tuition and fees per student charged to out-of-state students by private institutions, institutional characteristics, and the economic and political characteristics of the states?

Research Question 1e relates to Hypothesis 1e, that no statistically significant relationship exists between the amount of tuition and fees per student charged to out-of-state students by private institutions, institutional characteristics, and the economic and political characteristics of the states.

As described in Chapter 3, the Equation 1e relates to Research Question 1e and Hypothesis 1e:

$$
\mathrm{TPVO}_{\mathrm{i}}=\mathrm{SE}_{\mathrm{i}}+\mathrm{CC}_{\mathrm{i}}+\mathrm{CR}_{\mathrm{i}}+\mathrm{DEM}_{\mathrm{i}}+\mathrm{DEPRPB}_{\mathrm{i}}
$$

Because private institutions charge the same tuition and fees for in-state and out-of state students, the statistical data and the resultant econometric equation for this calculation are identical to the data for Equation $1 \mathrm{~b}$.

Significant relationships exist between the amount of tuition and fees per student charged to out-of-state students by private institutions and the selectivity of the institutions, their Carnegie Foundation classifications, the per-capita tax revenue for the states in which they are operated, and the annual depreciation expense per student. These relationships are represented by the following econometric equation:

$$
\mathrm{TPVO}_{\mathrm{i}}=-2642.735 \mathrm{SE}_{\mathrm{i}}-666.765 \mathrm{CC}_{\mathrm{i}}+1.400 \mathrm{CR}_{\mathrm{i}}+1.393 \mathrm{DEPRPV}_{\mathrm{i}}+13365.769
$$


Research Question 1f: Do the amounts of tuition and fees per student charged to outof-state students at private institutions differ significantly from the out-of-state tuition charged to out-of-state students at public institutions? Research Question $1 \mathrm{f}$ relates to Hypothesis 1f, that tuition and fees per student charged to out-of-state students by private institutions is less than or equal to the tuition and fees charged to out-of-state students by public institutions. As described in Chapter 3, Equation 1f relates to Research Question 1f and Hypothesis 1f: $\mathrm{TPVO} \leq \mathrm{TPBO}$.

The results of the means comparison are displayed in Table 27. Although the standard deviation for private institutions does not exceed three times the standard deviation of public institutions, the variances of the two sets of data were tested do determine if they were heterogeneous. The Levene's Test for Equality of Variances was calculated to detect heterogeneity between the data for public and private institutions. The $F$ statistic for this test was 137.087 , indicating a significant level of heterogeneity. The $t$ value for the comparison of the two means was -24.958 for $1,364.946$ degrees of freedom and a significance of less than .01 . These results indicate that the variance between the two means is significant.

Table 27: Equation 1f group statistics

\begin{tabular}{|l|l|r|r|r|c|}
\hline & $\begin{array}{l}\text { Control of } \\
\text { institution }\end{array}$ & $\mathrm{N}$ & Mean & $\begin{array}{c}\text { Std. } \\
\text { Deviation }\end{array}$ & $\begin{array}{c}\text { Std. } \\
\text { Error } \\
\text { Mean }\end{array}$ \\
\hline $\begin{array}{l}\text { Out-of-state } \\
\text { tuition and fees } \\
\text { per student }\end{array}$ & Public (TPBO) & 506 & 11192.420 & 3400.597 & 151.175 \\
\cline { 2 - 6 } & Private (TPVO) & 861 & 17421.220 & 5826.709 & 198.574 \\
\hline
\end{tabular}

Research Question 2a: Is there a statistically significant relationship between the amount of revenues collected from private donations per student by public institutions, 
institutional characteristics, and academic programs? Research Question 2a relates to

Hypothesis 2a, that no significant relationship exists between the amount of revenues collected from private donations per student by public institutions, institutional characteristics, and academic programs. As described in Chapter 3, Equation 2a relates to Research Question 2a and Hypothesis 2a:

$$
\mathrm{DONPB}_{\mathrm{i}}=\mathrm{SE}_{\mathrm{i}}+\mathrm{CC}_{\mathrm{i}}+\mathrm{DEPRPB}_{\mathrm{i}}+\mathrm{PROGI}_{\mathrm{i}}
$$

The significance scores for the independent variables of this equation are displayed in Table 28 . Alpha was set at .05 for all calculations.

Table 28: Equation 2a coefficients

\begin{tabular}{|l|r|r|r|r|r|}
\hline & \multicolumn{2}{|c|}{$\begin{array}{c}\text { Unstandardized } \\
\text { Coefficients }\end{array}$} & $\begin{array}{l}\text { Standardized } \\
\text { Coefficients }\end{array}$ & \multicolumn{2}{|c|}{} \\
\cline { 2 - 6 } & \multicolumn{1}{c|}{ B } & Std. Error & \multicolumn{1}{c|}{ Beta } & \multicolumn{1}{c|}{$t$} & \multicolumn{1}{c|}{ Sig. } \\
\hline (Constant) & -8912.661 & 6054.031 & & -1.472 & .143 \\
\hline $\begin{array}{l}\text { Selectivity of the institution } \\
\text { (SE) }\end{array}$ & -262.722 & 216.879 & -.077 & -1.211 & .228 \\
\hline $\begin{array}{l}\text { Carnegie Foundation } \\
\text { Classification (CC) }\end{array}$ & -39.380 & 31.540 & -.086 & -1.249 & .214 \\
\hline $\begin{array}{l}\text { Public Depreciation } \\
\text { Expenses Per Student }\end{array}$ & .336 & .040 & .595 & 8.484 & .001 \\
\hline Humanities (PROGI1) & 91.611 & 60.778 & 1.516 & 1.507 & .134 \\
\hline $\begin{array}{l}\text { Social/ behavioral sciences } \\
\text { (PROGI2) }\end{array}$ & 95.174 & 63.391 & 1.076 & 1.501 & .135 \\
\hline Life sciences (PROGI3) & 82.675 & 61.568 & .704 & 1.343 & .181 \\
\hline $\begin{array}{l}\text { Physical sciences (PROGI4) } \\
\text { Computer/ information }\end{array}$ & 102.780 & 75.634 & .309 & 1.359 & .176 \\
\hline science (PROGI6) & 86.578 & 60.603 & .439 & 1.429 & .155 \\
\hline \begin{tabular}{l} 
Engineering (PROGI7) \\
\hline
\end{tabular} & 93.450 & 61.359 & 1.443 & 1.523 & .130 \\
\hline
\end{tabular}




\begin{tabular}{|l|r|r|r|r|r|}
\hline Education (PROGI8) & & & & & \\
\hline $\begin{array}{l}\text { Business/ management } \\
\text { (PROGI9) }\end{array}$ & 96.638 & 61.121 & 1.279 & 1.581 & .116 \\
\hline Health (PROGI10) & 88.078 & 60.228 & .862 & 1.462 & .146 \\
\hline $\begin{array}{l}\text { Vocational/ technical } \\
\text { (PROGI1) }\end{array}$ & 75.950 & 61.470 & .488 & 1.236 & .219 \\
\hline $\begin{array}{l}\text { Other technical/ professional } \\
\text { (PROGI12) }\end{array}$ & 99.449 & 60.492 & 1.124 & 1.644 & .102 \\
\hline
\end{tabular}

Only the variable Public depreciation expense per student (DEPRPB) was significant; consequently, a second regression equation was calculated without the insignificant variables. The coefficient for this equation is displayed in Table 29.

Table 29: Equation 2a second calculation coefficient

\begin{tabular}{|l|r|r|r|r|r|}
\hline \multirow{2}{*}{} & \multicolumn{2}{|c|}{$\begin{array}{c}\text { Unstandardized } \\
\text { Coefficients }\end{array}$} & $\begin{array}{c}\text { Standardized } \\
\text { Coefficients }\end{array}$ & \multicolumn{2}{|c|}{} \\
\cline { 2 - 6 } & \multicolumn{1}{|c|}{ B } & $\begin{array}{c}\text { Std. } \\
\text { Error }\end{array}$ & Beta & $t$ & Sig. \\
\hline (Constant) & -496.583 & 36.258 & & -13.696 & .001 \\
\hline $\begin{array}{l}\text { Public Depreciation } \\
\text { Expenses Per Student }\end{array}$ & .847 & .015 & .929 & 56.459 & .001 \\
\hline
\end{tabular}

The Pearson product-moment correlation $(r)$ coefficient was .929 . Because the significance number for this equation was less than .01 , the $r$ statistic is significant. The coefficient of determination was .864. From this statistic, we may conclude that 86.4 percent of the variance in the amount of revenues collected from private donations per student for public institutions is explained by the independent variable in this equation. The $F$ statistic for the ANOVA was 3187.600, indicating that variances among the sample data for each variable exceeded the variance within the sample data for each variable. The critical value for a .05 level of significance and 502 degrees of freedom is \pm 1.96 . The $t$ values for variables except 
Depreciation expenses per student exceed the critical value. The variables with $t$ values in excess of the critical value are not significant. Because only one independent variable remains, no collinearity problems exist. The correlations for this equation are displayed in Table 30 .

Table 30: Equation 2a coefficients

\begin{tabular}{|c|c|c|c|}
\hline & & $\begin{array}{l}\text { Total amount of } \\
\text { revenues collected } \\
\text { from private donations } \\
\text { per student for public } \\
\text { institutions } \\
\end{array}$ & $\begin{array}{c}\text { Public } \\
\text { Depreciation } \\
\text { Expense per } \\
\text { Student }\end{array}$ \\
\hline \multirow{3}{*}{$\begin{array}{l}\text { Total amount of revenues } \\
\text { collected from private } \\
\text { donations per student for } \\
\text { public institutions } \\
\text { (DONPB) }\end{array}$} & Correlation & 1 & .929 \\
\hline & Sig. (1-tailed) & & .001 \\
\hline & $\mathrm{N}$ & 504 & 504 \\
\hline \multirow{3}{*}{$\begin{array}{l}\text { Public Depreciation } \\
\text { Expense per Student } \\
\text { (DEPRPB) }\end{array}$} & Correlation & .929 & 1 \\
\hline & Sig. (1-tailed) & .001 & \\
\hline & $\mathrm{N}$ & 504 & 504 \\
\hline
\end{tabular}

The only significant relationship identified from this analysis was between the amount of revenues collected from private donations per student by public institutions and the depreciation expense per student for public institutions. This relationship is represented by the following econometric equation:

$\mathrm{DONPB}_{\mathrm{i}}=+.847 \mathrm{DEPRPB}_{\mathrm{i}}-496.583$

\section{Research Question 2b: Is there a statistically significant relationship between the}

amount of revenues collected from private donations per student by private institutions, institutional characteristics, and academic programs? Research Question $2 b$ relates to Hypothesis $2 \mathrm{~b}$, that no significant relationship exists between the amount of revenues collected from private donations per student by private institutions, institutional characteristics, and academic programs. As described in Chapter 3, Equation $2 \mathrm{~b}$ relates to Research Question $2 \mathrm{~b}$ and Hypothesis 2b: 


$$
\mathrm{DONPV}_{\mathrm{i}}=\mathrm{SE}_{\mathrm{i}}+\mathrm{CC}_{\mathrm{i}}+\mathrm{DEPRPB}_{\mathrm{i}}+\mathrm{PROGI}_{\mathrm{i}}
$$

The significance scores for the independent variables of this equation are displayed in Table 31 .

The variables Selectivity and Public depreciation per student are significant. Alpha was set at 05 for all calculations.

Table 31: Equation 2b coefficients

\begin{tabular}{|c|c|c|c|c|c|}
\hline & $\begin{array}{r}\text { Unstand } \\
\text { Coeffi }\end{array}$ & $\begin{array}{l}\text { rdized } \\
\text { ients }\end{array}$ & $\begin{array}{l}\text { Standardized } \\
\text { Coefficients }\end{array}$ & & \\
\hline & $\mathrm{B}$ & Std. Error & Beta & $t$ & Sig. \\
\hline (Constant) & 22560.149 & 52264.714 & & .432 & .666 \\
\hline $\begin{array}{l}\text { Selectivity of the institution } \\
\text { (SE) }\end{array}$ & -5993.305 & 1903.526 & -.208 & -3.149 & .002 \\
\hline $\begin{array}{l}\text { Carnegie Foundation } \\
\text { Classification (CC) }\end{array}$ & 311.874 & 198.430 & .099 & 1.572 & .117 \\
\hline $\begin{array}{l}\text { Private Depreciation } \\
\text { Expenses Per Student }\end{array}$ & .822 & .214 & .247 & 3.838 & .001 \\
\hline Humanities ( PROGI1) & -172.622 & 525.352 & -.343 & -.329 & .743 \\
\hline $\begin{array}{l}\text { Social/ behavioral sciences } \\
\text { (PROGI2) }\end{array}$ & -172.741 & 540.662 & -.269 & -.319 & .750 \\
\hline Life sciences (PROGI3) & -167.762 & 525.421 & -.258 & -.319 & .750 \\
\hline $\begin{array}{l}\text { Physical sciences } \\
\text { (PROGI4) }\end{array}$ & 313.461 & 670.529 & .063 & .467 & .641 \\
\hline $\begin{array}{l}\text { Computer/ information } \\
\text { science (PROGI6) }\end{array}$ & -189.398 & 538.550 & -.170 & -.352 & .725 \\
\hline Engineering (PROGI7) & -204.846 & 531.487 & -.274 & -.385 & .700 \\
\hline Education (PROGI8) & -194.206 & 523.797 & -.451 & -.371 & .711 \\
\hline $\begin{array}{l}\text { Business/ management } \\
\text { (PROGI9) }\end{array}$ & -176.665 & 521.665 & -.329 & -.339 & .735 \\
\hline Health (PROGI10) & -142.437 & 524.441 & -.258 & -.272 & .786 \\
\hline
\end{tabular}




\begin{tabular}{|l|r|r|r|r|r|}
\hline $\begin{array}{l}\text { Vocational/ technical } \\
\text { (PROGI11) }\end{array}$ & 4.643 & 524.883 & .003 & .009 & .993 \\
\hline $\begin{array}{l}\text { Other technical/ } \\
\text { professional (PROGI12) }\end{array}$ & -226.932 & 524.025 & -.288 & -.433 & .665 \\
\hline
\end{tabular}

Because only the variables Selectivity and Private depreciation expense are significant, a second regression equation was calculated without the insignificant variables. The coefficients for this equation are displayed in Table 32. The variables used in this calculation were significant. The Pearson product-moment correlation $(r)$ coefficient was .501. Because the significance number for this equation was less than .01 , the $r$ statistic is significant. The coefficient of determination was .251. From this statistic, we may conclude that 25.1 percent of the variance in the amount of revenues collected from private donations per student for private institutions is explained by the independent variables in this equation. The $F$ statistic for the ANOVA was 121.812, indicating that variances among the sample data for each variable exceeded the variance within the sample data for each variable. The critical value for a .05 level of significance and 728 degrees of freedom is \pm 1.96 . The variables are significant because their $t$ values exceed the critical value.

To determine if collinear relationships exist among the independent variables, variable inflation factors (VIF) were computed. For each variable, the VIF was slightly above 1 and the corresponding tolerance levels were slightly below 1 , indicating no significant collinearity problems.

Table 32: Equation $2 \mathrm{~b}$ second calculation coefficients

\begin{tabular}{|l|c|c|c|c|c|c|c|}
\hline & \multicolumn{2}{|c|}{$\begin{array}{c}\text { Unstandardized } \\
\text { Coefficients }\end{array}$} & $\begin{array}{l}\text { Standardized } \\
\text { Coefficients }\end{array}$ & & \multicolumn{2}{|c|}{$\begin{array}{c}\text { Collinearity } \\
\text { Statistics }\end{array}$} \\
\cline { 2 - 8 } & \multicolumn{1}{c}{$\mathrm{B}$} & Std. Error & Beta & $T$ & Sig. & Tolerance & VIF \\
\hline (Constant) & 4099.570 & 976.156 & & 4.200 & .001 & & \\
\hline & -3738.188 & 1241.080 & -.108 & -3.012 & .003 & .805 & 1.243 \\
\hline
\end{tabular}




\begin{tabular}{|l|r|r|r|r|r|r|r|}
\hline $\begin{array}{l}\text { Selectivity } \\
\text { of the } \\
\text { institution } \\
\text { (SE) }\end{array}$ & & & & & & & \\
\hline $\begin{array}{l}\text { Private } \\
\text { Depreciation } \\
\begin{array}{l}\text { Expenses } \\
\text { Per Student } \\
\text { (DEPRP) }\end{array}\end{array}$ & 1.741 & .140 & .444 & 12.406 & .001 & .805 & 1.243 \\
\hline
\end{tabular}

The Collinearity Diagnostics for this equation are displayed in Table 33. Because no two variance proportions within a dimension exceed .5 and the condition index for dimension 5 is relatively large, these variables are not significantly correlated with each other.

Table 33: Equation $2 \mathrm{~b}$ collinearity diagnostics

\begin{tabular}{|l|l|l|l|}
\hline Dimension & 1 & 2 & 3 \\
\hline Eigenvalue & 2.527 & .448 & .025 \\
\hline Condition Index & 1.000 & 2.375 & 10.098 \\
\hline Constant & .010 & .010 & .990 \\
\hline $\begin{array}{l}\text { Selectivity of the institution } \\
\text { (SE) }\end{array}$ & .010 & .030 & .960 \\
\hline $\begin{array}{l}\text { Private Depreciation Expense } \\
\text { per STUDENT (DEPRPV) }\end{array}$ & .040 & .630 & .320 \\
\hline
\end{tabular}

The correlations for this equation are displayed in Table 34.

Table 34: Equation 2b correlations

\begin{tabular}{|c|c|c|c|c|}
\hline & & $\begin{array}{l}\text { Total amount of } \\
\text { revenues } \\
\text { collected from } \\
\text { private donations } \\
\text { per student for } \\
\text { public institutions }\end{array}$ & $\begin{array}{l}\text { Selectivity } \\
\text { of the } \\
\text { institution }\end{array}$ & $\begin{array}{c}\text { Annual } \\
\text { depreciation } \\
\text { expense per } \\
\text { student }\end{array}$ \\
\hline \multirow{3}{*}{$\begin{array}{l}\text { Total amount of } \\
\text { revenues collected from } \\
\text { private donations per }\end{array}$} & Correlation & 1 & -.304 & .491 \\
\hline & Sig. (1-tailed) & & .001 & .001 \\
\hline & $\mathrm{N}$ & 731 & 731 & 731 \\
\hline
\end{tabular}




\begin{tabular}{|l|l|r|r|r|}
\hline $\begin{array}{l}\text { student for public } \\
\text { institutions (DONPV) }\end{array}$ & & & & \\
\hline \multirow{2}{*}{$\begin{array}{l}\text { Selectivity of the } \\
\text { institution (SE) }\end{array}$} & Correlation & -.304 & 1 & -.442 \\
\cline { 2 - 5 } & Sig. (1-tailed) & .001 & & .001 \\
\cline { 2 - 5 } & $\mathrm{N}$ & 731 & 731 & 731 \\
\hline \multirow{2}{*}{$\begin{array}{l}\text { Annual depreciation } \\
\text { expense per student } \\
\text { (DEPRPV) }\end{array}$} & Correlation & .491 & -.442 & 1 \\
\cline { 2 - 5 } & Sig. (1-tailed) & .001 & .001 & \\
\cline { 2 - 5 } & $\mathrm{N}$ & 731 & 731 & 731 \\
\hline
\end{tabular}

Significant relationships were identified between the amount of revenues collected from private donations per student by private institutions and the selectivity of the institutions as well as their depreciation expenses per student. These relationships are represented by the following econometric equation:

$\mathrm{DONPV}_{\mathrm{i}}=-3738.188 \mathrm{SE}+1.741 \mathrm{DEPRPV}_{\mathrm{i}}+4099.570$

Research Question 2c: Do the amount of revenues collected from private donations per student by private institutions differ significantly from the amount of revenues collected from private donations per student donations received by public institutions? Research Question $2 \mathrm{c}$ relates to Hypothesis $2 \mathrm{c}$, that the private donations per student by private institutions is less than or equal to the private donations received by public institutions.

As described in Chapter 3, Equation 2c relates to Research Question 2c and Hypothesis 2c:

\section{DONPV $\leq$ DONPB}

The results of the means comparison are displayed in Table 35. Although the standard deviation for private institutions does not exceed three times the standard deviation of public institutions, the variances of the two sets of data were tested do determine if they were heterogeneous. The Levene's Test for Equality of Variances was calculated to detect heterogeneity between the data for public and private institutions. The $F$ statistic for this test was 
166.419, indicating a significant level of heterogeneity. The $t$ value for the comparison of the two means was -16.344 for $1,021.305$ degrees of freedom and a significance of less than .01 . The results of this analysis indicate that the difference between the two means is significant.

Table 35: Equation 2c group statistics

\begin{tabular}{|l|l|c|c|c|c|}
\hline & $\begin{array}{l}\text { Control of } \\
\text { institution }\end{array}$ & $\mathrm{N}$ & Mean & \multicolumn{1}{c|}{$\begin{array}{c}\text { Std. } \\
\text { Deviation }\end{array}$} & $\begin{array}{c}\text { Std. Error } \\
\text { Mean }\end{array}$ \\
\hline $\begin{array}{l}\text { Total amount of } \\
\text { revenues collected } \\
\text { from donations per } \\
\text { student }\end{array}$ & Public & 504 & 431.471 & 1965.0385 & 87.530 \\
\cline { 2 - 6 } & Private non-profit & 797 & 4351.001 & 6303.137 & 223.269 \\
\hline
\end{tabular}

Research Question 3a: Is there a statistically significant relationship between the amount of state appropriations per student received by public institutions, institutional characteristics, the economic and political characteristics of the states in which the institutions operate, academic programs, and the available pools of students within the states? Research Question 3a relates to Hypothesis $\left(\mathrm{H}_{3 \mathrm{a}}\right)$, that there is no significant relationship between the amount of state appropriations per student received by public institutions, institutional characteristics, the economic and political characteristics of the states in which the institutions operate, academic programs, and the available pools of students within the states. As described in Chapter 3, Equation 3a relates to Research Question 3a and Hypothesis 3a:

$$
\mathrm{APPPB}_{\mathrm{i}}=\mathrm{SE}_{\mathrm{i}}+\mathrm{CC}_{\mathrm{i}}+\mathrm{CR}_{\mathrm{i}}+\mathrm{R}_{\mathrm{i}}+2 \mathrm{Y}_{\mathrm{i}}+\mathrm{DEPRPB}_{\mathrm{i}}+\mathrm{PROGI}_{\mathrm{i}}+\mathrm{DEM}_{\mathrm{i}}
$$

The significance scores for the independent variables of this equation are displayed in Table 36. The variables Selectivity, Current enrollment as a percentage of the sum of the high-school graduates for the past four years, and Public Depreciation per student are significant. Alpha was set at .05 for all calculations. 
Table 36: Equation 3a coefficients

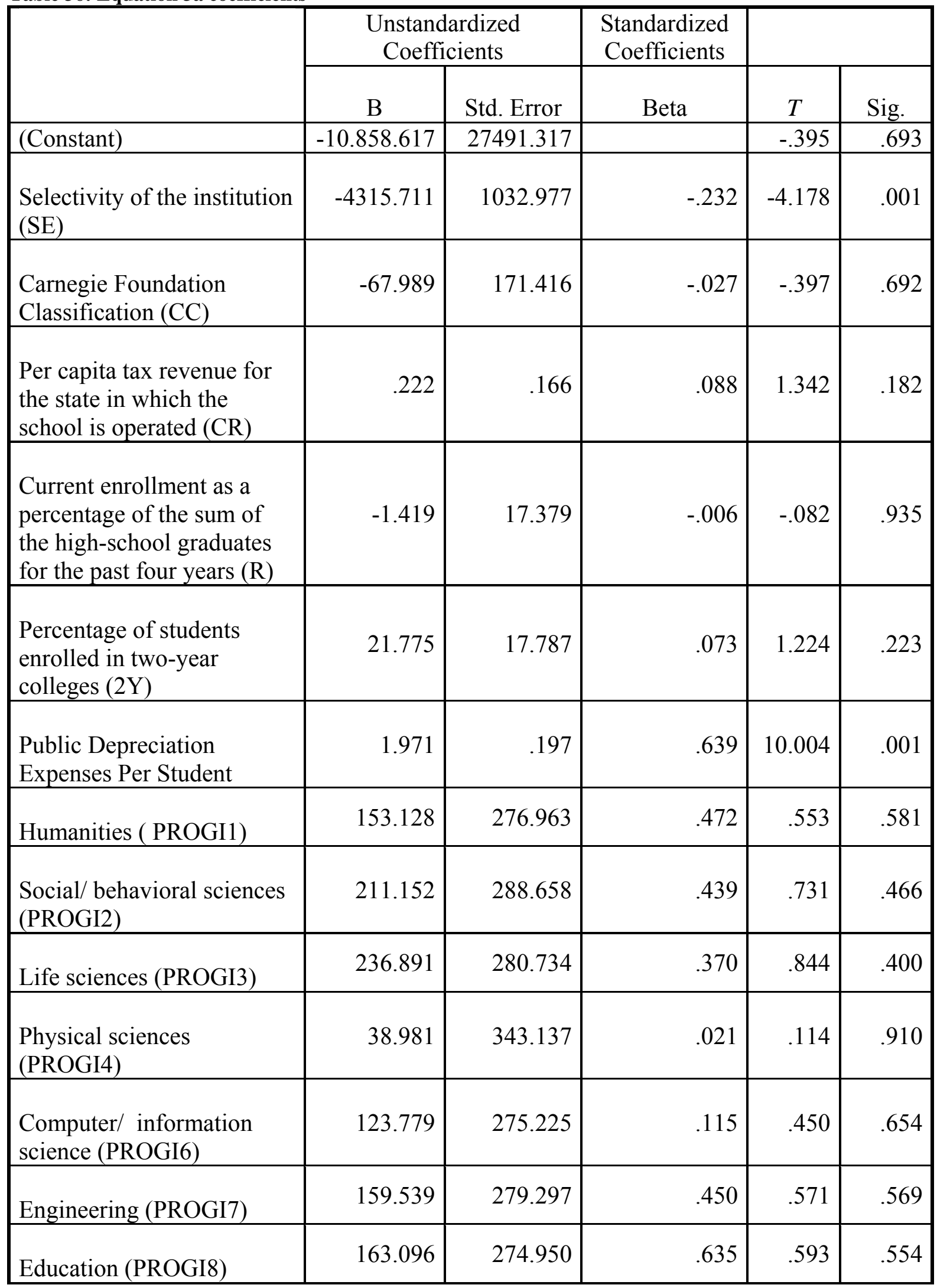




\begin{tabular}{|l|r|r|r|r|r|}
\hline $\begin{array}{l}\text { Business/ management } \\
\text { (PROGI9) }\end{array}$ & 174.450 & 278.331 & .424 & .627 & .532 \\
\hline Health (PROGI10) & 154.408 & 273.946 & .276 & .564 & .574 \\
\hline $\begin{array}{l}\text { Vocational/ technical } \\
\text { (PROGI11) }\end{array}$ & 143.234 & 279.394 & .168 & .513 & .609 \\
\hline $\begin{array}{l}\text { Other technical/ } \\
\text { professional (PROGI12) }\end{array}$ & 144.307 & 275.567 & .298 & .524 & .601 \\
\hline $\begin{array}{l}\text { Political Power in the } \\
\text { Legislature (DEM) }\end{array}$ & -15.259 & 15.069 & -.059 & -1.013 & .313 \\
\hline
\end{tabular}

Because no variables except for Selectivity and Public Depreciation per student are significant, a second regression equation was calculated without the insignificant variables. The coefficients for this equation are displayed in Table 37. The variables used in this calculation were significant. The Pearson product-moment correlation $(r)$ coefficient was .657 . Because the significance number for this equation was less than .01 , the $r$ statistic is significant. The coefficient of determination was .432 From this statistic, we may conclude that 43.2 percent of the variance in the amount of revenues collected from private donations per student for private institutions is explained by the independent variables in this equation. The $F$ statistic for the ANOVA was 169.577, indicating that variances among the sample data for each variable exceeded the variance within the sample data for each variable. The critical value for a .05 level of significance and 446 degrees of freedom is \pm 1.96 . The variables are significant because their $t$ values exceed the critical value.

Table 37: Equation 3a second calculation coefficients

\begin{tabular}{|l|c|c|c|c|c|c|c|}
\hline \multirow{2}{*}{} & \multicolumn{2}{|c|}{$\begin{array}{c}\text { Unstandardized } \\
\text { Coefficients }\end{array}$} & $\begin{array}{c}\text { Standardized } \\
\text { Coefficients }\end{array}$ & \multicolumn{2}{|c|}{$\begin{array}{c}\text { Collinearity } \\
\text { Statistics }\end{array}$} \\
\cline { 2 - 9 } & $\mathrm{B}$ & $\begin{array}{c}\text { Std. } \\
\text { Error }\end{array}$ & Beta & $t$ & Sig. & Tolerance & VIF \\
\hline & 5925.304 & 470.133 & & 12.603 & .001 & & \\
\hline (Constant) & -2684.374 & 610.905 & -.158 & -4.394 & .001 & .991 & 1.009 \\
\hline
\end{tabular}




\begin{tabular}{|c|c|c|c|c|c|c|c|}
\hline $\begin{array}{l}\text { Selectivity } \\
\text { of the } \\
\text { institution } \\
\text { (SE) }\end{array}$ & & & & & & & \\
\hline $\begin{array}{l}\text { Public } \\
\text { Depreciation } \\
\text { Expenses } \\
\text { Per Student } \\
\text { (DEPRPB) }\end{array}$ & 2.107 & .121 & .623 & 17.385 & .001 & .991 & 1.009 \\
\hline
\end{tabular}

To determine if collinear relationships exist among the independent variables, variable inflation factors (VIF) were computed. For each variable, the VIF was slightly above 1 and the corresponding tolerance levels were slightly below 1, indicating no significant collinearity problems.

The Collinearity Diagnostics for this equation are displayed in Table 38. Because the variance proportions for any of the variables do not exceed .5 and the condition indexes are not relatively large, no variables are significantly correlated with each other.

Table 38: Equation 3a collinearity diagnostics

\begin{tabular}{|l|l|l|l|}
\hline Dimension & 1 & 2 & 3 \\
\hline Eigenvalue & 2.648 & .325 & .027 \\
\hline Condition Index & 1.000 & 2.855 & 9.904 \\
\hline Constant & .010 & .020 & .980 \\
\hline $\begin{array}{l}\text { Selectivity of the } \\
\text { institution (SE) }\end{array}$ & .010 & .030 & .960 \\
\hline $\begin{array}{l}\text { Public Depreciation } \\
\text { Expenses per student } \\
\text { (DEPRPB) }\end{array}$ & .050 & .890 & .060 \\
\hline
\end{tabular}

The correlations for this equation are displayed in Table 39.

Table 39: Equation 3a correlations 


\begin{tabular}{|c|c|c|c|c|}
\hline & & $\begin{array}{l}\text { State } \\
\text { Appropriations } \\
\text { Per Student }\end{array}$ & $\begin{array}{l}\text { Selectivity } \\
\text { of the } \\
\text { institution }\end{array}$ & $\begin{array}{l}\text { Public } \\
\text { Depreciation } \\
\text { Expenses Per } \\
\text { Student }\end{array}$ \\
\hline \multirow{3}{*}{$\begin{array}{l}\text { State } \\
\text { Appropriations } \\
\text { Per Student } \\
\text { (APPPB) }\end{array}$} & Correlation & 1 & -.217 & .638 \\
\hline & Sig. (1-tailed) & & .001 & .001 \\
\hline & $\mathrm{N}$ & 449 & 449 & 449 \\
\hline \multirow{3}{*}{$\begin{array}{l}\text { Selectivity of the } \\
\text { institution (SE) }\end{array}$} & Correlation & -.217 & 1 & -.095 \\
\hline & Sig. (1-tailed) & .001 & & .022 \\
\hline & $\mathrm{N}$ & 449 & 449 & 449 \\
\hline \multirow{3}{*}{$\begin{array}{l}\text { Public } \\
\text { Depreciation } \\
\text { Expenses Per } \\
\text { Student } \\
\text { (DEPRPB) }\end{array}$} & Correlation & .638 & -.095 & 1 \\
\hline & Sig. (1-tailed) & .001 & .022 & \\
\hline & $\mathrm{N}$ & 446 & 446 & 446 \\
\hline
\end{tabular}

This regression analysis shows significant relationships between the amount of state appropriations per student received by public institutions and the selectivity of the institutions and their depreciation expenses per student. These relationships are represented by the following econometric equation:

$\mathrm{APPPB}_{\mathrm{i}}=-2684.374 \mathrm{SE}+2.107 \mathrm{DEPRPB}+5925.304$

Research Question 3b: Is there a statistically significant relationship between the amount of state appropriations per student received by private institutions, institutional characteristics, the economic and political characteristics of the states in which the institutions operate, academic programs, and the available pools of students within the states? Research Question 3b relates to Hypothesis $\left(\mathrm{H}_{3 \mathrm{~b}}\right)$, that there is no significant relationship between the amount of state appropriations per student received by private institutions, institutional characteristics, the economic and political characteristics of the states in which the institutions operate, academic programs, and the available pools of high school graduates within 
the states. As described in Chapter 3, Equation 3b relates to Research Question 3b and Hypothesis $3 b$ :

$$
\mathrm{APPPV}_{\mathrm{i}}=\mathrm{SE}_{\mathrm{i}}+\mathrm{CC}_{\mathrm{i}}+\mathrm{CR}_{\mathrm{i}}+\mathrm{R}_{\mathrm{i}}+2 \mathrm{Y}_{\mathrm{i}}+\mathrm{DEPRPV}_{\mathrm{i}}+\mathrm{PROGI}_{\mathrm{i}}+\mathrm{DEM}_{\mathrm{i}}
$$

Alpha was set at .05 for all calculations. The coefficient data is displayed in Table 40 .

None of the correlations between the independent variables and the dependent variable were statistically significant. The Pearson product-moment correlation $(r)$ coefficient was .240 . The coefficient of determination was .057 . The F-statistic for this equation is .897 , indicating that the relationship is not significant. As a result, an econometric equation cannot be constructed.

Table 40: Equation 3b coefficients

\begin{tabular}{|l|c|c|c|c|c|}
\hline \multirow{2}{*}{} & \multicolumn{2}{|c|}{$\begin{array}{c}\text { Unstandardized } \\
\text { Coefficients }\end{array}$} & $\begin{array}{l}\text { Standardized } \\
\text { Coefficients }\end{array}$ & \multicolumn{2}{|c|}{} \\
\cline { 2 - 6 } & \multicolumn{1}{c|}{$\mathrm{B}$} & Std. Error & \multicolumn{1}{c|}{ Beta } & \multicolumn{1}{c|}{ Sig. } \\
\hline (Constant) & 569.863 & 2581.896 & & .221 & .825 \\
\hline $\begin{array}{l}\text { Selectivity of the institution } \\
\text { (SE) }\end{array}$ & 45.150 & 96.402 & .032 & .468 & .640 \\
\hline $\begin{array}{l}\text { Carnegie Foundation } \\
\text { Classification (CC) }\end{array}$ & -13.729 & 11.031 & -.086 & -1.245 & .214 \\
\hline $\begin{array}{l}\text { Per capita tax revenue for the } \\
\text { state in which the school is } \\
\text { operated (CR) }\end{array}$ & -.049 & .019 & -.177 & -2.603 & .010 \\
\hline $\begin{array}{l}\text { Current enrollment as a } \\
\text { percentage of the sum of the } \\
\text { high-school graduates for the } \\
\text { past four years (R) }\end{array}$ & 2.274 & 6.202 & .025 & .367 & .714 \\
\hline $\begin{array}{l}\text { Percentage of students } \\
\text { enrolled in two-year colleges } \\
\text { (2Y) }\end{array}$ & -2.580 & 1.552 & -.111 & -1.662 & .098 \\
\hline $\begin{array}{l}\text { Private Depreciation Expenses } \\
\text { Per Student (DEPRPV) }\end{array}$ & .005 & .010 & .032 & .467 & .641 \\
\hline
\end{tabular}




\begin{tabular}{|l|r|r|r|r|r|}
\hline Humanities (PROGI1) & -2.019 & 25.863 & -.080 & -.078 & .938 \\
\hline $\begin{array}{l}\text { Social/ behavioral sciences } \\
\text { (PROGI2) }\end{array}$ & -.574 & 26.607 & -.018 & -.022 & .983 \\
\hline Life sciences (PROGI3) & -2.479 & 25.825 & -.078 & -.096 & .924 \\
\hline Physical sciences (PROGI4) & 9.177 & 33.351 & .037 & .275 & .783 \\
\hline $\begin{array}{l}\text { Computer/ information } \\
\text { science (PROGI6) }\end{array}$ & -1.973 & 26.564 & -.032 & -.074 & .941 \\
\hline Engineering (PROGI7) & -3.731 & 26.216 & -.099 & -.142 & .887 \\
\hline Education (PROGI8) & -2.979 & 25.748 & -.143 & -.116 & .908 \\
\hline $\begin{array}{l}\text { Business/ management } \\
\text { (PROGI9) }\end{array}$ & -1.968 & 25.731 & -.074 & -.076 & .939 \\
\hline Health (PROGI10) & -.740 & 25.826 & -.026 & -.029 & .977 \\
\hline $\begin{array}{l}\text { Vocational/ technical } \\
\text { (PROGI11) }\end{array}$ & 1.379 & 25.857 & .021 & .053 & .958 \\
\hline $\begin{array}{l}\text { Other technical/ professional } \\
\text { (PROGI12) }\end{array}$ & -2.167 & 25.792 & -.054 & -.084 & .933 \\
\hline $\begin{array}{l}\text { Political power in the } \\
\text { legislature (DEM) }\end{array}$ & 1.716 & 1.363 & .090 & 1.259 & .209 \\
\hline
\end{tabular}

Research Question 3c: Do the state appropriations per student received by public institutions differ significantly from the state appropriations received by private institutions? Research Question 3c relates to Hypothesis $\left(\mathrm{H}_{3 \mathrm{c}}\right)$, that the amount of state appropriations received by private institutions is less than or equal to the amount of state appropriations received by public institutions.

As described in Chapter 3, Equation 3c relates to Research Question 3c and Hypothesis 3c: 
$\mathrm{APPPV} \leq \mathrm{APPPB}$

The results of the means comparison are displayed in Table 41. Although the standard deviation for private institutions does not exceed three times the standard deviation of public institutions, the variances of the two sets of data were tested do determine if they were heterogeneous. The Levene's Test for Equality of Variances was calculated to detect heterogeneity between the data for public and private institutions. The $F$ statistic for this test was 325.1921 , indicating a significant level of heterogeneity. The $t$ value for the comparison of the two means was -32.25794 for 1514.1378 degrees of freedom and a significance of less than .01 . These results indicate that the difference between the two means is significant.

Table 41: Equation 3c group statistics

\begin{tabular}{|l|l|c|r|r|r|}
\hline & $\begin{array}{l}\text { Control of } \\
\text { institution }\end{array}$ & $\mathrm{N}$ & Mean & $\begin{array}{c}\text { Std. } \\
\text { Deviation }\end{array}$ & $\begin{array}{c}\text { Std. Error } \\
\text { Mean }\end{array}$ \\
\hline $\begin{array}{l}\text { Total amount of } \\
\text { revenues collected from } \\
\text { state appropriations per } \\
\text { student }\end{array}$ & Public & 512 & 6296.534 & 4374.669 & 193.335 \\
\cline { 2 - 6 } & $\begin{array}{l}\text { Private non- } \\
\text { profit }\end{array}$ & 873 & 50.388 & 316.432 & 10.709 \\
\hline
\end{tabular}

\section{Research Question 4a: Is there a significant relationship between the amount of}

federal revenues received by public institutions, their statuses as land grant institutions, institutional characteristics, and academic programs? Research Question 4a relates to Hypothesis $\left(\mathrm{H}_{4 \mathrm{a}}\right)$, that there is no significant relationship between the amount of federal revenues received by public institutions, their statuses as land grant institutions, institutional characteristics, and academic programs. As described in Chapter 3, Equation 4a relates to Research Question 4a and Hypothesis 4a:

$$
\mathrm{FRPB}_{\mathrm{i}}=\mathrm{STAT}_{2} 2_{\mathrm{i}}+\mathrm{STAT} 0_{\mathrm{i}}+\mathrm{SE}_{i}+\mathrm{CC}_{\mathrm{i}}+\mathrm{DEPRPB}_{\mathrm{i}}+\mathrm{PROGI}_{\mathrm{i}}
$$


The significance scores for the independent variables of this equation are displayed in Table 42 .

Only the variable Public Depreciation Expenses per student is significant. Alpha was set at .05 for all calculations.

Table 42: Equation 4a coefficients

\begin{tabular}{|c|c|c|c|c|c|}
\hline & \multicolumn{2}{|c|}{$\begin{array}{l}\text { Unstandardized } \\
\text { Coefficients }\end{array}$} & \multirow{2}{*}{$\begin{array}{c}\text { Standardized } \\
\text { Coefficients } \\
\text { Beta } \\
\end{array}$} & \multirow[b]{2}{*}{$t$} & \multirow[b]{2}{*}{ Sig. } \\
\hline & B & Std. Error & & & \\
\hline (Constant) & -13682.605 & 26646.108 & & -.513 & .608 \\
\hline $\begin{array}{l}\text { Institution's status as an } 1862 \\
\text { land grant institution } \\
\text { (STAT62) }\end{array}$ & -945.750 & 758.462 & -.056 & -1.247 & .214 \\
\hline $\begin{array}{l}\text { Selectivity of the institution } \\
\text { (SE) }\end{array}$ & -1033.333 & 952.818 & -.049 & -1.085 & .280 \\
\hline $\begin{array}{l}\text { Carnegie Foundation } \\
\text { Classification (CC) }\end{array}$ & -186.745 & 137.658 & -.067 & -1.357 & .177 \\
\hline $\begin{array}{l}\text { Public Depreciation Expenses } \\
\text { Per Student (DEPRPB) }\end{array}$ & 2.774 & .173 & .799 & 16.002 & .001 \\
\hline Humanities ( PROGI1) & 139.989 & 268.033 & .383 & .522 & .602 \\
\hline $\begin{array}{l}\text { Social/ behavioral sciences } \\
\text { (PROGI2) }\end{array}$ & 130.097 & 278.805 & .240 & .467 & .641 \\
\hline Life sciences (PROGI3) & 194.368 & 271.577 & .269 & .716 & .475 \\
\hline Physical sciences (PROGI4) & 115.158 & 333.414 & .056 & .345 & .730 \\
\hline $\begin{array}{l}\text { Computer/ information } \\
\text { science (PROGI6) }\end{array}$ & 185.680 & 266.605 & .153 & 696 & .487 \\
\hline Engineering (PROGI7) & 142.926 & 270.159 & .358 & .529 & .598 \\
\hline Education (PROGI8) & 155.489 & 266.373 & .537 & .584 & .560 \\
\hline $\begin{array}{l}\text { Business/ management } \\
\text { (PROGI9) }\end{array}$ & 150.927 & 269.049 & .326 & .561 & .576 \\
\hline & 168.027 & 265.233 & 267 & .634 & .527 \\
\hline
\end{tabular}




\begin{tabular}{|l|r|r|r|r|r|}
\hline Health (PROGI10) & & & & & \\
\hline $\begin{array}{l}\text { Vocational/ technical } \\
\text { (PROGI1) }\end{array}$ & 87.463 & 271.280 & .091 & .322 & .748 \\
\hline $\begin{array}{l}\text { Other technical/ professional } \\
\text { (PROGI12) }\end{array}$ & 143.078 & 266.362 & .262 & .537 & .592 \\
\hline
\end{tabular}

As noted above, only the variable Public depreciation expenses per student was significant, consequently, a second regression equation without the insignificant variable. The coefficient for this equation is displayed in Table 43. The Pearson product-moment correlation $(r)$ coefficient was .960 . Because the significance number for this equation was less than .01 , the $r$ statistic is significant. The coefficient of determination was .922 . From this statistic, we may conclude that 92.2 percent of the variance in the amount of revenues collected from federal revenues received by public institutions is explained by the independent variable in this equation. The $F$ statistic for the ANOVA was 6065.911, indicating that variances among the sample data for each variable exceeded the variance within the sample data for each variable. The critical value for a .05 level of significance and 510 degrees of freedom is \pm 1.96 . The variable is significant because its $t$ value exceed the critical value. Because only one variable was used for this equation, there are no collinearity problems.

Table 43: Equation 4a second calculation coefficients

\begin{tabular}{|c|c|c|c|c|c|c|c|}
\hline & \multicolumn{2}{|c|}{$\begin{array}{c}\text { Unstandardized } \\
\text { Coefficients }\end{array}$} & \multirow{2}{*}{$\begin{array}{c}\text { Standardized } \\
\text { Coefficients } \\
\text { Beta } \\
\end{array}$} & \multirow[b]{2}{*}{$t$} & \multirow[b]{2}{*}{ Sig. } & \multicolumn{2}{|c|}{$\begin{array}{c}\text { Collinearity } \\
\text { Statistics }\end{array}$} \\
\hline & B & $\begin{array}{c}\text { Std. } \\
\text { Error }\end{array}$ & & & & Tolerance & VIF \\
\hline (Constant) & -838.675 & 112.428 & & -7.460 & .001 & & \\
\hline $\begin{array}{l}\text { Public } \\
\text { Depreciation } \\
\text { Expenses Per } \\
\text { Student } \\
\text { (DEPRPB) }\end{array}$ & 3.652 & .047 & .960 & 77.884 & .001 & 1.000 & 1.000 \\
\hline
\end{tabular}


The correlation for this equation is displayed in Table 44.

Table 44: Equation 4a correlation

\begin{tabular}{|c|c|c|c|}
\hline & & $\begin{array}{l}\text { Federal operating } \\
\text { revenues } \\
\text { provided per } \\
\text { student }\end{array}$ & $\begin{array}{l}\text { Public } \\
\text { Depreciation } \\
\text { Expenses Per } \\
\text { Student }\end{array}$ \\
\hline \multirow{3}{*}{$\begin{array}{l}\text { Federal operating } \\
\text { revenues provided per } \\
\text { student (FRPB) }\end{array}$} & Correlation & 1 & 960 \\
\hline & Sig. (1-tailed) & & .001 \\
\hline & $\mathrm{N}$ & 512 & 512 \\
\hline \multirow{3}{*}{$\begin{array}{l}\text { Public Depreciation } \\
\text { Expenses Per Student } \\
\text { (DEPRPB) }\end{array}$} & Correlation & .960 & 1 \\
\hline & Sig. (1-tailed) & .001 & \\
\hline & $\mathrm{N}$ & 512 & 512 \\
\hline
\end{tabular}

Only the relationship between the amount of federal revenues received by public institutions and depreciation expenses per student is significant. This relationship is represented by the following econometric equation:

$\mathrm{FRPB}=3.652 \mathrm{DEPRPB}+-838.675$

\section{Research Question 4b: Is there a significant relationship between the amount of} federal revenues received by private institutions, their statuses as land grant institutions, institutional characteristics, and academic programs? Research Question $4 \mathrm{~b}$ relates to Hypothesis $\left(\mathrm{H}_{4 \mathrm{~b}}\right)$, that there is no significant relationship between the amount of federal revenues received by private institutions, their statuses as land grant institutions, institutional characteristics, and academic programs. As described in Chapter 3, Equation $4 \mathrm{~b}$ relates to Research Question 4b and Hypothesis 4b:

$$
\mathrm{FRPV}_{\mathrm{i}}=\mathrm{STAT}_{62_{\mathrm{i}}}+\mathrm{STAT} 0_{\mathrm{i}}+\mathrm{SE}_{\mathrm{i}}+\mathrm{CC}_{\mathrm{i}}+\mathrm{DEPRPB}_{\mathrm{i}}+\mathrm{PROGI}_{\mathrm{i}}
$$


The significance scores for the independent variables of this equation are displayed in Table 45 .

Only the variables Institution's status as an 1862 land grant institution, Carnegie Foundation classification, and Private depreciation expenses per student, were significant. Alpha was set at .05 for all calculations.

Table 45: Equation 4b coefficients

\begin{tabular}{|c|c|c|c|c|c|}
\hline & \multicolumn{2}{|c|}{$\begin{array}{c}\text { Unstandardized } \\
\text { Coefficients }\end{array}$} & \multirow{2}{*}{$\begin{array}{c}\begin{array}{c}\text { Standardized } \\
\text { Coefficients }\end{array} \\
\text { Beta } \\
\end{array}$} & \multirow[b]{2}{*}{$t$} & \multirow[b]{2}{*}{ Sig. } \\
\hline & B & Std. Error & & & \\
\hline (Constant) & -54205.272 & 57723.179 & & -.939 & .349 \\
\hline $\begin{array}{l}\text { Institution's status as an } 1862 \\
\text { land grant institution } \\
\text { (STAT62) }\end{array}$ & 3916.080 & 1817.141 & .085 & 2.155 & .032 \\
\hline $\begin{array}{l}\text { Institution's status as an } 1890 \\
\text { land grant institution } \\
\text { (STAT90) }\end{array}$ & 733.173 & 3440.387 & .008 & .213 & .831 \\
\hline $\begin{array}{l}\text { Selectivity of the institution } \\
\text { (SE) }\end{array}$ & 614.109 & 2134.485 & .012 & .288 & .774 \\
\hline $\begin{array}{l}\text { Carnegie Foundation } \\
\text { Classification (CC) }\end{array}$ & -632.842 & 224.044 & -.116 & -2.825 & .005 \\
\hline $\begin{array}{l}\text { Private Depreciation Expenses } \\
\text { Per STUDENT (DEPRPV) }\end{array}$ & 3.966 & .235 & .727 & 16.909 & .001 \\
\hline Humanities ( PROGI1) & 509.562 & 580.149 & .574 & .878 & .381 \\
\hline $\begin{array}{l}\text { Social/ behavioral sciences } \\
\text { (PROGI2) }\end{array}$ & 580.144 & 597.580 & .522 & .971 & .332 \\
\hline Life sciences (PROGI3) & 573.229 & 578.867 & .515 & .990 & .323 \\
\hline Physical sciences (PROGI4) & -92.173 & 749.441 & -.011 & -.123 & .902 \\
\hline $\begin{array}{l}\text { Computer/ information } \\
\text { science (PROGI6) }\end{array}$ & 657.166 & 593.507 & .332 & 1.107 & .269 \\
\hline Engineering (PROGI7) & 531.327 & 588.185 & .398 & .903 & .367 \\
\hline
\end{tabular}




\begin{tabular}{|l|r|r|r|r|r|}
\hline Education (PROGI8) & 506.054 & 578.027 & .693 & .875 & .382 \\
\hline $\begin{array}{l}\text { Business/ management } \\
\text { (PROGI9) }\end{array}$ & 538.894 & 577.148 & .584 & .934 & .351 \\
\hline Health (PROGI10) & 451.075 & 579.237 & .477 & .779 & .437 \\
\hline $\begin{array}{l}\text { Vocational/ technical } \\
\text { (PROGI11) }\end{array}$ & 505.481 & 580.572 & .216 & .871 & .385 \\
\hline $\begin{array}{l}\text { Other technical/ professional } \\
\text { (PROGI12) }\end{array}$ & 542.670 & 578.312 & .400 & .938 & .349 \\
\hline
\end{tabular}

As noted above, only three variables were significant; consequently, a second regression equation was calculated without the insignificant variables. The coefficients for this equation are displayed in Table 46. All variables used in this calculation were significant. The Pearson product-moment correlation $(r)$ coefficient was .713. Because the significance number for this equation was less than .01 , the $r$ statistic is significant. The coefficient of determination was .508. From this statistic, we may conclude that 50.8 percent of the variance in the amount of revenues collected from private donations per student for private institutions is explained by the independent variables in this equation. The $F$ statistic for the ANOVA was 299.547, indicating that variances among the sample data for each variable exceeded the variance within the sample data for each variable. The critical value for a .05 level of significance and 869 degrees of freedom is \pm 1.96 . The variables are significant because their $t$ values exceed the critical value.

To determine if collinear relationships exist among the independent variables, variable inflation factors (VIF) were computed. Significant collinearity problems existed for all variables except for Carnegie foundation classification because the VIFs were significantly above 1 and the corresponding tolerance levels were significantly below 1.

Table 46: Equation 4b second calculation coefficients \begin{tabular}{|l|l|}
\hline & Unstandardized
\end{tabular} Coefficients

\begin{tabular}{|c|c|c|}
\hline $\begin{array}{c}\text { Standardized } \\
\text { Coefficients }\end{array}$ & \\
\hline
\end{tabular}




\begin{tabular}{|l|c|c|c|c|c|}
\hline & $\mathrm{B}$ & $\begin{array}{c}\text { Std. } \\
\text { Error }\end{array}$ & Beta & \multicolumn{1}{c|}{$T$} & \multicolumn{1}{c|}{ Sig. } \\
\hline (Constant) & -44.606 & 581.158 & & -.077 & .939 \\
\hline $\begin{array}{l}\text { Institution's status as an 1862 } \\
\text { land grant institution } \\
\text { (STAT62) }\end{array}$ & 2548.366 & 928.760 & .065 & 2.744 & .006 \\
\hline $\begin{array}{l}\text { Carnegie Foundation } \\
\text { Classification (CC) }\end{array}$ & -595.671 & 111.409 & -.132 & -5.347 & .001 \\
\hline $\begin{array}{l}\text { Private Depreciation } \\
\text { Expenses Per STUDENT } \\
\text { (DEPRPV) }\end{array}$ & 2.981 & .110 & .667 & 27.029 & .001 \\
\hline
\end{tabular}

The Collinearity Diagnostics for this equation are displayed in Table 47. No combination of values in any Dimension exceeds .5; therefore, no significant correlation problems exist among these variables.

Table 47: Equation $4 \mathrm{~b}$ collinearity diagnostics

\begin{tabular}{|l|l|l|l|l|}
\hline Dimension & 1 & 2 & 3 & 4 \\
\hline Eigenvalue & 2.544 & .957 & .451 & .049 \\
\hline Condition Index & 1.000 & 1.631 & 2.375 & 7.240 \\
\hline Constant & .010 & .000 & .010 & .970 \\
\hline $\begin{array}{l}\text { Institution's status as an } \\
\text { 1862 land grant institution } \\
\text { (STAT1862) }\end{array}$ & .010 & .970 & .020 & .000 \\
\hline $\begin{array}{l}\text { Carnegie Foundation } \\
\text { Classification (CC) }\end{array}$ & .010 & .000 & .060 & .930 \\
\hline $\begin{array}{l}\text { Private Depreciation } \\
\text { Expenses Per STUDENT } \\
\text { (DEPRPV) }\end{array}$ & .050 & .010 & .730 & .200 \\
\hline
\end{tabular}

The correlations for this equation are displayed in Table 48. 
Table 48: Equation 4b correlations

\begin{tabular}{|c|c|c|c|c|c|}
\hline & & $\begin{array}{l}\text { Federal } \\
\text { operating } \\
\text { revenues } \\
\text { provided } \\
\text { per } \\
\text { student }\end{array}$ & $\begin{array}{l}\text { Institution's } \\
\text { status as an } \\
1862 \text { land } \\
\text { grant } \\
\text { institution }\end{array}$ & $\begin{array}{l}\text { Carnegie } \\
\text { Foundation } \\
\text { Classification }\end{array}$ & $\begin{array}{l}\text { Private } \\
\text { Depreciation } \\
\text { Expenses Per } \\
\text { STUDENT }\end{array}$ \\
\hline \multirow{3}{*}{$\begin{array}{l}\text { Federal } \\
\text { operating } \\
\text { revenues } \\
\text { provided per } \\
\text { student } \\
\text { (FFPV) }\end{array}$} & Correlation & 1 & .036 & -.306 & .699 \\
\hline & $\begin{array}{l}\text { Sig. (1-tailed) } \\
\end{array}$ & & .144 & .001 & .001 \\
\hline & $\mathrm{N}$ & 873 & 873 & 873 & 873 \\
\hline \multirow{3}{*}{$\begin{array}{l}\text { Institution's } \\
\text { status as an } \\
1862 \text { land } \\
\text { grant } \\
\text { institution } \\
\text { (1862STAT) }\end{array}$} & Correlation & .036 & 1 & .013 & -.041 \\
\hline & Sig. (1-tailed) & .144 & & .348 & .112 \\
\hline & $\mathrm{N}$ & 873 & 873 & 873 & 873 \\
\hline \multirow{3}{*}{$\begin{array}{l}\text { Carnegie } \\
\text { Foundation } \\
\text { Classification } \\
\text { (CC) } \\
\end{array}$} & Correlation & -.306 & .013 & 1 & -.262 \\
\hline & Sig. (1-tailed) & .001 & .348 & & .001 \\
\hline & $\mathrm{N}$ & 873 & 873 & 873 & 873 \\
\hline \multirow{3}{*}{$\begin{array}{l}\text { Private } \\
\text { Depreciation } \\
\text { Expenses Per } \\
\text { STUDENT } \\
\text { (DEPRPV) }\end{array}$} & Correlation & .699 & -.041 & -.262 & 1 \\
\hline & Sig. (1-tailed) & .001 & .112 & .001 & \\
\hline & $\mathrm{N}$ & 873 & 873 & 873 & 873 \\
\hline
\end{tabular}

Significant relationships were identified between the amount of federal revenues received per student by private institutions, the institutions' statuses as 1862 land grant institutions, their Carnegie Foundation classifications, and their depreciation expenses per student. These relationships are represented by the following econometric equation:

$\mathrm{FRPV}=2548.366 \mathrm{STAT} 62-595.671 \mathrm{CC}+2.981 \mathrm{DEPRPV}-44.606$

Research Question 4c: Do the federal revenues received by public institutions differ significantly from the federal revenues received by private institutions? Research Question $4 \mathrm{c}$ 
relates to Hypothesis $\left(\mathrm{H}_{4 \mathrm{c}}\right)$, that the amount of federal revenues received by private institutions is less than or equal to the amount of federal revenues received by public institutions.

As described in Chapter 3, Equation 4c relates to Research Question 4c and Hypothesis 4c:

$\mathrm{FRPV} \leq \mathrm{FRPB}$

The results of the means comparison are displayed in Table 49. Although the standard deviation for private institutions does not exceed three times the standard deviation of public institutions, the variances of the two sets of data were tested do determine if they were heterogeneous. The Levene's Test for Equality of Variances was calculated to detect heterogeneity between the data for public and private institutions. The $F$ statistic for this test was .001 , indicating no significant level of heterogeneity. The $t$ value for the comparison of the two means was 2.42 for 957.2834228 degrees of freedom and a significance of .994 . The results of this analysis indicate that the difference between the two means is significant.

Table 49: Equation 4c group statistics

\begin{tabular}{|l|l|c|r|r|r|}
\hline & $\begin{array}{l}\text { Control of } \\
\text { institution }\end{array}$ & $\mathrm{N}$ & Mean & Std. Deviation & $\begin{array}{c}\text { Std. Error } \\
\text { Mean }\end{array}$ \\
\hline $\begin{array}{l}\text { Federal } \\
\text { operating } \\
\text { revenues } \\
\text { provided per } \\
\text { student }\end{array}$ & Public & 512 & 3099.854 & 8150.670 & 360.212 \\
\cline { 2 - 6 } & $\begin{array}{l}\text { Private } \\
\text { non-profit }\end{array}$ & 873 & 2049.927 & 7111.125 & 240.675 \\
\hline
\end{tabular}

Research Question 5a: Is there a significant relationship between institutional meritbased financial grant aid paid per student by public institutions, student characteristics, and academic programs? Research Question 5a relates to Hypothesis $\left(\mathrm{H}_{5 \mathrm{a}}\right)$, that there is no significant relationship between institutional merit-based financial grant aid per student paid by 
public institutions, student characteristics, and academic programs. As described in Chapter 3,

Equation 5a relates to Research Question 5a and Hypothesis 5a:

$$
\mathrm{IFPBM}_{\mathrm{i}}=\mathrm{SA}_{\mathrm{i}}+\mathrm{SAGI}_{\mathrm{i}}+\mathrm{SR}_{\mathrm{i}}+\mathrm{SG}_{\mathrm{i}}+\mathrm{SPEL}_{\mathrm{i}}+\mathrm{SGPA}_{\mathrm{i}}+\mathrm{SVA}_{\mathrm{i}}+\mathrm{LOC}_{\mathrm{i}}+\mathrm{PROGN}_{\mathrm{i}}
$$

The significance scores for this equation are displayed in Table 50. The NCES' DAS was used to perform a weighted least squares computation using NPSAS: 04 data.

Table 50: Equation 5a hypothesis testing results

\begin{tabular}{|l|r|r|r|r|r|}
\hline & Wald F & \multicolumn{1}{l|}{$\begin{array}{l}\text { Num. } \\
\text { DF }\end{array}$} & $\begin{array}{l}\text { Denom. } \\
\text { DF }\end{array}$ & Commonality & Probability F \\
\hline Overall Fit & 8.618 & 34 & 31 & & .001 \\
\hline Age (SA) & 187.763 & 1 & 64 & .006 & .001 \\
\hline $\begin{array}{l}\text { Adjusted Gross Income } \\
\text { (SAGI) }\end{array}$ & 2.142 & 1 & 64 & 0 & .148 \\
\hline Race (SR) & 5.372 & 5 & 60 & .004 & .001 \\
\hline Gender (SG) & .678 & 1 & 64 & .001 & .413 \\
\hline $\begin{array}{l}\text { Parent's highest } \\
\text { education level (SPEL) }\end{array}$ & 1.645 & 10 & 55 & .007 & .118 \\
\hline $\begin{array}{l}\text { Grade point average } \\
\text { (SGPA) }\end{array}$ & 116.773 & 1 & 64 & 0 & .001 \\
\hline Veteran status (SVA) & 15.031 & 1 & 64 & .017 & .001 \\
\hline $\begin{array}{l}\text { Attend institution in } \\
\text { state of legal residence } \\
\text { (LOC) }\end{array}$ & 22.097 & 2 & 63 & & .001 \\
\hline Program (PROGN) & 1.423 & 12 & 53 & .002 & .185 \\
\hline
\end{tabular}

The variables Adjusted Gross Income (SAGI), Gender (SG), Parent's highest education level (SPEL), and field of study (PROGN) were not significant. Because they were not significant, a second computation was completed without these variables. The significance scores for this computation are displayed in Table 51. All of the variables in this equation were significant. The coefficient of determination was .038. From this statistic, we may conclude that 3.8 percent of the variance in institutional merit-based financial grant aid per student paid by public institutions is explained by the independent variables in this equation. 
Table 51: Equation 5a hypothesis testing results second calculation

\begin{tabular}{|l|r|r|r|r|r|}
\hline & Wald $F$ & $\begin{array}{l}\text { Num. } \\
\text { DF }\end{array}$ & Denom. DF & Commonality & Probability F \\
\hline Overall Fit & 30.102 & 10 & 55 & & .001 \\
\hline Age (SA) & 242.854 & 1 & 64 & .008 & .001 \\
\hline Race (SR) & 5.146 & 5 & 60 & .004 & .001 \\
\hline $\begin{array}{l}\text { Grade point average } \\
\text { (SGPA) }\end{array}$ & 117.654 & 1 & 64 & .008 & .001 \\
\hline $\begin{array}{l}\text { Veteran status } \\
\text { (SVA) }\end{array}$ & 14.520 & 1 & 64 & 0 & .001 \\
\hline $\begin{array}{l}\text { Attend institution in } \\
\text { state of legal } \\
\text { residence (LOC) }\end{array}$ & 22.786 & 2 & 63 & .018 & .001 \\
\hline
\end{tabular}

The estimated full sample regression coefficients for the second calculation are displayed in Table 52. Because the $t$ values for the variables White, Black or African American, Grade point average, veteran status, and attend institution in state of legal residence - yes exceed \pm 1.96 , they are significant.

Table 52: Equation 5a estimated full sample regression coefficients

\begin{tabular}{|l|r|r|r|}
\hline & \multicolumn{1}{l|}{ B } & \multicolumn{1}{l|}{ s.e. } & \multicolumn{1}{l|}{} \\
\hline Intercept & 691.336 & 350.196 & 1.974 \\
\hline Age (SA) & -18.941 & 1.215 & -15.584 \\
\hline Race & & & \\
\hline White (SR1) & 93.420 & 46.357 & 2.015 \\
\hline Black or African American (SR2) & 328.538 & 100.916 & 3.256 \\
\hline Hispanic or Latino (SR3) & 3.332 & 51.375 & .065 \\
\hline Asian (SR4) & -67.414 & 80.443 & -.838 \\
\hline Other (SR5) & 21.213 & 61.428 & .345 \\
\hline vs. More than one race & & & \\
\hline Grade point average & 1.946 & .179 & 10.847 \\
\hline Veteran status (SVA) & & & \\
\hline Not a veteran & 89.161 & 23.399 & 3.811 \\
\hline vs. Veteran & & & \\
\hline $\begin{array}{l}\text { Attend institution in state of legal } \\
\text { residence (LOC) }\end{array}$ & & & \\
\hline Yes (LOC1) & -756.66 & 325.475 & -2.325 \\
\hline No (LOC2) & -101.510 & 340.422 & -.298 \\
\hline
\end{tabular}

The correlations for this equation are displayed in Table 53. 
Table 53: Equation 5a correlations

\begin{tabular}{|c|c|c|c|c|c|c|}
\hline & $\begin{array}{l}\text { Institutional } \\
\text { merit-only } \\
\text { grants }\end{array}$ & Age & White & $\begin{array}{l}\text { Black or } \\
\text { African } \\
\text { American }\end{array}$ & $\begin{array}{l}\text { Hispanic } \\
\text { or } \\
\text { Latino }\end{array}$ & Asian \\
\hline $\begin{array}{l}\text { Institutional } \\
\text { merit-only } \\
\text { grants } \\
\text { (IFPBM) } \\
\end{array}$ & 1 & -.089 & .006 & .040 & -.029 & -.013 \\
\hline Age (SA) & -.089 & 1 & -.038 & .067 & .001 & -.036 \\
\hline White (R1) & .006 & -.038 & 1 & -.532 & -.463 & -.392 \\
\hline $\begin{array}{l}\text { Black or } \\
\text { African } \\
\text { American } \\
\text { (R2) }\end{array}$ & .040 & .067 & -.532 & 1 & -.102 & -.086 \\
\hline $\begin{array}{l}\text { Hispanic or } \\
\text { Latino (R3) }\end{array}$ & -.029 & .001 & -.463 & -.102 & 1 & -.075 \\
\hline Asian (R4) & -.013 & -.036 & -.392 & -.086 & -.075 & 1 \\
\hline Other (R5) & -.014 & .032 & -.256 & -.057 & -.049 & -.042 \\
\hline $\begin{array}{l}\text { Grade point } \\
\text { average } \\
\text { (SGPA) }\end{array}$ & .076 & .133 & .121 & -.132 & -.054 & .016 \\
\hline $\begin{array}{l}\text { Veteran } \\
\text { status=Not a } \\
\text { veteran (SVA) }\end{array}$ & .026 & -.202 & .011 & -.021 & .007 & .012 \\
\hline $\begin{array}{l}\text { Attend } \\
\text { institution in } \\
\text { state of legal } \\
\text { residence=Yes } \\
\text { (LOC1) }\end{array}$ & -.147 & .095 & .028 & -.040 & .043 & -.064 \\
\hline $\begin{array}{l}\text { Attend } \\
\text { institution in } \\
\text { state of legal } \\
\text { residence=No } \\
\text { (LOC2) }\end{array}$ & .131 & -.097 & .023 & .033 & -.048 & -.020 \\
\hline
\end{tabular}

Table 53: Equation 5a correlations (continued)

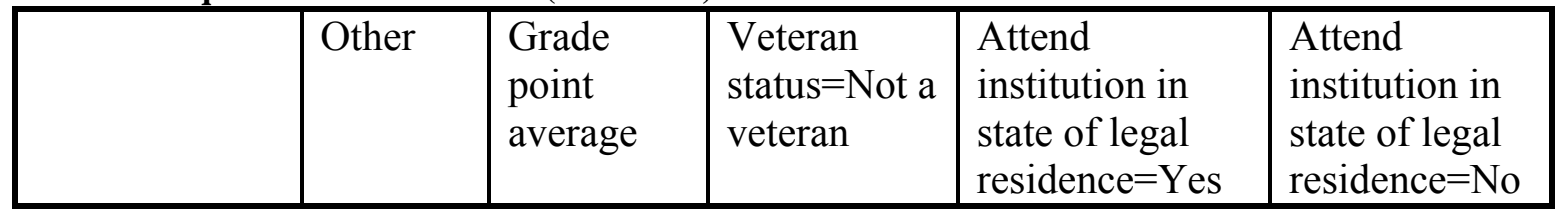




\begin{tabular}{|c|c|c|c|c|c|}
\hline $\begin{array}{l}\text { Institutional } \\
\text { merit-only } \\
\text { grants }\end{array}$ & -.014 & .076 & .026 & -.147 & .131 \\
\hline Age (SA) & .032 & .133 & -.202 & .095 & -.097 \\
\hline White (SR1) & -.256 & .121 & .011 & .028 & .025 \\
\hline $\begin{array}{l}\text { Black or } \\
\text { African } \\
\text { American } \\
\text { (SR2) }\end{array}$ & -.057 & -.132 & -.021 & -.039 & .033 \\
\hline $\begin{array}{l}\text { Hispanic or } \\
\text { Latino (SR3) }\end{array}$ & -.049 & -.054 & .007 & .043 & -.048 \\
\hline Asian (SR4) & -.042 & .016 & .012 & -.064 & -.020 \\
\hline Other (SR5) & 1 & -.009 & -.021 & .014 & -.021 \\
\hline $\begin{array}{l}\text { Grade point } \\
\text { average } \\
\text { (SGPA) }\end{array}$ & -.009 & 1 & -.027 & -.023 & .008 \\
\hline $\begin{array}{l}\text { Veteran } \\
\text { status=Not a } \\
\text { veteran (SVA) }\end{array}$ & -.021 & -.027 & 1 & -.027 & .021 \\
\hline $\begin{array}{l}\text { Attend } \\
\text { institution in } \\
\text { state of legal } \\
\text { residence=Yes } \\
\text { (LOC1) }\end{array}$ & .014 & -.023 & -.027 & 1 & -.906 \\
\hline $\begin{array}{l}\text { Attend } \\
\text { institution in } \\
\text { state of legal } \\
\text { residence=No } \\
\text { (LOC2) }\end{array}$ & -.021 & .008 & .021 & -.906 & 1 \\
\hline
\end{tabular}

The results of this regression analysis indicate that significant relationships exist between the amount of institutional merit-based financial grant aid paid per student by public institutions and students' ages, the race classifications White and Black or African American, students' grade point averages, their veteran status, and their attendance at an institution in the same state of their residence. These relationships are represented by the following econometric equation:

$\mathrm{IFPBM}_{\mathrm{i}}=-18.941 \mathrm{SA}_{\mathrm{i}}+93.42 \mathrm{SR} 1+328.538 \mathrm{SR} 2+1.946 \mathrm{SGPA}_{\mathrm{i}}+89.161 \mathrm{SVA}_{\mathrm{i}}-756.66 \mathrm{LOC}_{\mathrm{i}}+$ 691.336 
Research Question 5b: Is there a significant relationship between institutional meritbased financial grant aid paid per student by private institutions, student characteristics, and academic programs? Research Question $5 \mathrm{~b}$ relates to Hypothesis $\left(\mathrm{H}_{5 \mathrm{~b}}\right)$, that there is no significant relationship between institutional merit-based financial grant aid paid per student by private institutions, student characteristics, and academic programs. As described in Chapter 3, Equation $5 b$ relates to Research Question $5 b$ and Hypothesis $5 b$ :

$$
\mathrm{IFPVM}_{\mathrm{i}}=\mathrm{SA}_{\mathrm{i}}+\mathrm{SAGI}_{\mathrm{i}}+\mathrm{SR}_{\mathrm{i}}+\mathrm{SG}_{\mathrm{i}}+\mathrm{SPEL}_{\mathrm{i}}+\mathrm{SGPA}_{\mathrm{i}}+\mathrm{SVA}_{\mathrm{i}}+\mathrm{LOC}_{\mathrm{i}}+\mathrm{PROGN}_{\mathrm{i}}
$$

The significance scores for this equation are displayed in Table 54. The NCES' DAS was used to perform a weighted least squares computation using NPSAS: 04 data.

Table 54: Equation 5b hypothesis testing results

\begin{tabular}{|l|r|r|r|r|r|}
\hline & Wald $F$ & Num. DF & Denom. DF & Commonality & Probability $F$ \\
\hline Overall Fit & 9.802 & 34 & 31 & & .001 \\
\hline Age (SA) & 141.432 & 1 & 64 & .046 & .001 \\
\hline $\begin{array}{l}\text { Adjusted Gross } \\
\text { Income (SAGI) }\end{array}$ & 11.799 & 1 & 64 & .001 & .001 \\
\hline $\begin{array}{l}\text { Race-ethnicity } \\
\text { (SR) }\end{array}$ & 6.235 & 5 & 60 & .004 & .001 \\
\hline Gender (SG) & 1.805 & 1 & 64 & .000 & .184 \\
\hline $\begin{array}{l}\text { Parent's highest } \\
\text { education level } \\
\text { (SPEL) }\end{array}$ & 2.093 & 10 & 55 & .003 & .041 \\
\hline $\begin{array}{l}\text { Grade point } \\
\text { average (SGPA) }\end{array}$ & 102.236 & 1 & 64 & .021 & .001 \\
\hline $\begin{array}{l}\text { Veteran status } \\
\text { (SVA) }\end{array}$ & 2.209 & 1 & 64 & .000 & .142 \\
\hline $\begin{array}{l}\text { Attend } \\
\text { institution in } \\
\text { state of legal } \\
\text { residence (LOC) }\end{array}$ & 0.390 & 2 & 63 & .000 & .679 \\
\hline $\begin{array}{l}\text { Program } \\
\text { (PROGN) }\end{array}$ & 2.380 & 12 & 53 & & .009 \\
\hline
\end{tabular}

The variables Gender (SG) Veteran status (VA), and Attend institution in state of legal residence (LOC) were not significant. Because they were not significant, a second computation was 
completed without these variables. The significance scores for this computation are displayed in Table 55. All variables in this equation were significant. The coefficient of determination was .108. From this statistic, we may conclude that 10.8 percent of the variance in institutional meritbased financial grant aid per student paid by private institutions is explained by the independent variables in this equation. The DAS will not produce output for equations that have significant collinearity problems. As a result, no collinearity problems exist for this equation or any of the following equations produced from the DAS.

Table 55: Equation 5b hypothesis testing results second calculation

\begin{tabular}{|l|r|r|r|r|r|}
\hline & Wald $F$ & Num. DF & Denom. DF & Commonality & Probability $F$ \\
\hline Overall Fit & 9.877 & 30 & 35 & & .001 \\
\hline Age (SA) & 142.958 & 1 & 64 & .050 & .001 \\
\hline $\begin{array}{l}\text { Adjusted Gross } \\
\text { Income (SAGI) }\end{array}$ & 9.837 & 1 & 64 & .001 & .003 \\
\hline Race-ethnicity (SR) & 6.066 & 5 & 60 & .004 & .001 \\
\hline $\begin{array}{l}\text { Parent's highest } \\
\text { education level } \\
\text { (SPEL) }\end{array}$ & 2.072 & 10 & 55 & .003 & .043 \\
\hline $\begin{array}{l}\text { Grade point average } \\
\text { (SGPA) }\end{array}$ & 100.604 & 1 & 64 & .022 & .001 \\
\hline Program (PROGN) & 2.737 & 12 & 53 & .010 & .006 \\
\hline
\end{tabular}

The regression coefficients for the second calculation are displayed in Table 56. Because the $t$ scores for the variables Age, Adjusted gross income, Did not complete high school, High school diploma or equivalent, Vocational or technical training, Less than two years of college, Associate's degree, 2 or more years of college but no degree, Bachelor's degree, Master's degree or equivalent, Grade point average, and life sciences exceed \pm 1.96 , they are significant.

Table 56: Equation 5b estimated full sample regression coefficients

\begin{tabular}{|l|r|r|r|r|}
\hline & \multicolumn{1}{c}{ B } & \multicolumn{1}{r|}{ Probability $t$} \\
\hline Intercept & 868.004 & 420.443 & 2.064 & .043 \\
\hline Age (SA) & -101.259 & 8.469 & -11.957 & .001 \\
\hline Adjusted Gross Income (SAGI) & .002 & .001 & 3.136 & .003 \\
\hline Race-ethnicity & & & & \\
\hline
\end{tabular}




\begin{tabular}{|c|c|c|c|c|}
\hline White (R1) & 262.552 & 320.559 & .819 & .416 \\
\hline Black or African American (R2) & -148.579 & 359.825 & -.413 & .681 \\
\hline Hispanic or Latino (R3) & -286.733 & 327.046 & -.877 & .384 \\
\hline Asian (R4) & -410.533 & 330.171 & -1.243 & .218 \\
\hline Other (R5) & -433.200 & 359.879 & -1.204 & .233 \\
\hline \multicolumn{5}{|l|}{ vs. More than one race } \\
\hline \multicolumn{5}{|l|}{ Parent's highest education level } \\
\hline $\begin{array}{l}\text { Do not know parent's education } \\
\text { level (SPEL1) }\end{array}$ & 331.764 & 230.454 & 1.440 & .155 \\
\hline $\begin{array}{l}\text { Did not complete high school } \\
\text { (SPEL2) }\end{array}$ & 706.889 & 284.268 & 2.487 & .016 \\
\hline $\begin{array}{l}\text { High school diploma or } \\
\text { equivalent (SPEL3) }\end{array}$ & 446.145 & 188.245 & 2.370 & .021 \\
\hline $\begin{array}{l}\text { Vocational or technical training } \\
\text { (SPEL4) }\end{array}$ & 1066.287 & 363.528 & 2.933 & .005 \\
\hline $\begin{array}{l}\text { Less than two years of college } \\
\text { (SPEL5) }\end{array}$ & 590.934 & 229.699 & 2.573 & .012 \\
\hline Associate's degree (SPEL6) & 792.84 & 266.724 & 2.973 & .004 \\
\hline $\begin{array}{l}2 \text { or more years of college but no } \\
\text { degree (SPEL7) }\end{array}$ & 589.909 & 259.927 & 2.270 & .027 \\
\hline Bachelor's degree (SPEL8) & 629.544 & 186.279 & 3.38 & .001 \\
\hline $\begin{array}{l}\text { Master's degree or equivalent } \\
\text { (SPEL9) }\end{array}$ & 557.297 & 172.244 & 3.236 & .002 \\
\hline $\begin{array}{l}\text { First-professional degree } \\
\text { (SPEL10) }\end{array}$ & 374.557 & 302.27 & 1.239 & .220 \\
\hline \multicolumn{5}{|l|}{ vs. Doctoral degree or equivalent } \\
\hline Grade point average (SGPA) & 8.403 & .838 & 10.030 & .001 \\
\hline \multicolumn{5}{|l|}{ Field of study: undergraduate } \\
\hline $\begin{array}{l}\text { Undeclared or not in a degree } \\
\text { program (PROGN1) }\end{array}$ & -219.289 & 190.389 & -1.152 & .254 \\
\hline Humanities (PROGN2) & -56.372 & 187.927 & -.300 & .765 \\
\hline $\begin{array}{l}\text { Social/behavioral sciences } \\
\text { (PROGN3) }\end{array}$ & -47.952 & 226.721 & -.212 & .833 \\
\hline Life sciences (PROGN4) & 1120.855 & 335.435 & 3.341 & .001 \\
\hline Physical sciences (PROGN5) & 1283.071 & 681.913 & 1.882 & .064 \\
\hline Math (PROGN6) & 700.222 & 628.21 & 1.115 & .269 \\
\hline $\begin{array}{l}\text { Computer/information science } \\
\text { (PROGN7) }\end{array}$ & -480.38 & 260.431 & -1.845 & .070 \\
\hline Engineering (PROGN8) & 176.868 & 296.167 & .597 & .552 \\
\hline Education (PROGN9) & 236.000 & 201.604 & 1.171 & .246 \\
\hline $\begin{array}{l}\text { Business/management } \\
\text { (PROGN10) }\end{array}$ & -233.999 & 139.297 & -1.68 & .098 \\
\hline Health (PROGN11) & -79.883 & 226.399 & -.353 & .725 \\
\hline Vocational/technical & -742.196 & 502.639 & -1.477 & .145 \\
\hline
\end{tabular}




\begin{tabular}{|l|l|l|l|l|}
\hline (PROGN12) & & & & \\
\hline vs. Other technical/professional & & & & \\
\hline
\end{tabular}

The correlations for this equation are displayed in Table 57.

Table 57: Equation 5b correlations

\begin{tabular}{|c|c|c|c|c|c|}
\hline & $\begin{array}{l}\text { Institutional } \\
\text { merit-only } \\
\text { grants }\end{array}$ & Age & $\begin{array}{l}\text { Adjusted } \\
\text { Gross } \\
\text { Income } \\
\text { (AGI) }\end{array}$ & White & $\begin{array}{l}\text { Black or } \\
\text { African } \\
\text { American }\end{array}$ \\
\hline $\begin{array}{l}\text { Institutional merit- } \\
\text { only grants } \\
\text { (IFPVM) }\end{array}$ & 1 & -.247 & .101 & .117 & -.095 \\
\hline Age (SA) & -.247 & 1 & -.177 & -.082 & .128 \\
\hline $\begin{array}{l}\text { Adjusted Gross } \\
\text { Income (SAGI) }\end{array}$ & .101 & -.177 & 1 & .190 & -.179 \\
\hline White (SR1) & .117 & -.082 & .190 & 1 & -.603 \\
\hline $\begin{array}{l}\text { Black or African } \\
\text { American (SR2) }\end{array}$ & -.095 & .128 & -.179 & -.603 & 1 \\
\hline $\begin{array}{l}\text { Hispanic or Latino } \\
\text { (SR3) }\end{array}$ & -.051 & .022 & -.078 & -.46 & -.121 \\
\hline Asian (SR4) & -.016 & -.069 & -.013 & -.327 & -.085 \\
\hline Other (SR5) & -.024 & .016 & -.016 & -.206 & -.054 \\
\hline $\begin{array}{l}\text { Do not know } \\
\text { parent's education } \\
\text { level (SPEL1) }\end{array}$ & -.038 & .075 & -.073 & -.117 & .073 \\
\hline $\begin{array}{l}\text { Did not complete } \\
\text { high school } \\
\text { (SPEL2) } \\
\end{array}$ & -.062 & .216 & -.010 & -.159 & .093 \\
\hline $\begin{array}{l}\text { High school } \\
\text { diploma or } \\
\text { equivalent (SPEL3) }\end{array}$ & -.084 & .209 & -.167 & -.045 & .067 \\
\hline $\begin{array}{l}\text { Vocational or } \\
\text { technical training } \\
\text { (SPEL4) }\end{array}$ & .022 & .038 & -.056 & -.007 & .009 \\
\hline $\begin{array}{l}\text { Less than two years } \\
\text { of college (SPEL5) }\end{array}$ & .001 & -.002 & -.045 & -.004 & .024 \\
\hline $\begin{array}{l}\text { Associate's degree } \\
\text { (SPEL6) }\end{array}$ & .012 & .003 & -.035 & .006 & .009 \\
\hline $\begin{array}{l}2 \text { or more years of } \\
\text { college but no } \\
\text { degree (SPEL7) }\end{array}$ & -.009 & .012 & -.048 & -.002 & .037 \\
\hline $\begin{array}{l}\text { Bachelor's degree } \\
\text { (SPEL8) }\end{array}$ & .049 & -.121 & .048 & .038 & -.048 \\
\hline
\end{tabular}




\begin{tabular}{|c|c|c|c|c|c|}
\hline $\begin{array}{l}\text { Master's degree or } \\
\text { equivalent (SPEL9) }\end{array}$ & .055 & -.149 & 0.153 & .099 & -.075 \\
\hline $\begin{array}{l}\text { First-professional } \\
\text { degree (SPEL10) }\end{array}$ & .031 & -.091 & .104 & .039 & -.053 \\
\hline $\begin{array}{l}\text { Grade point average } \\
\text { (SGPA) }\end{array}$ & .129 & .158 & 0.100 & .160 & -.160 \\
\hline $\begin{array}{l}\text { Undeclared or not } \\
\text { in a degree program } \\
\text { (PROGN1) }\end{array}$ & -.020 & -.021 & .029 & .008 & -.042 \\
\hline $\begin{array}{l}\text { Humanities } \\
\text { (PROGN2) }\end{array}$ & 016 & -.064 & 017 & .045 & -.044 \\
\hline $\begin{array}{l}\text { Social/behavioral } \\
\text { sciences (PROGN3) }\end{array}$ & .020 & -.080 & .034 & .011 & -.032 \\
\hline $\begin{array}{l}\text { Life sciences } \\
\text { (PROGN4) }\end{array}$ & .101 & -.101 & .046 & -.006 & -.020 \\
\hline $\begin{array}{l}\text { Physical sciences } \\
\text { PROGN5) }\end{array}$ & .046 & -.040 & 018 & .008 & -.007 \\
\hline Math (PROGN6) & .029 & -.034 & -.009 & .010 & -.025 \\
\hline $\begin{array}{l}\text { Computer/informati } \\
\text { on science } \\
\text { (PROGN7) }\end{array}$ & -.045 & .069 & -.0245 & -.034 & .042 \\
\hline $\begin{array}{l}\text { Engineering } \\
\text { (PROGN8) }\end{array}$ & 019 & -.044 & .033 & .003 & -.019 \\
\hline $\begin{array}{l}\text { Education } \\
\text { (PROGN9) }\end{array}$ & .035 & -.014 & .007 & .059 & -.044 \\
\hline $\begin{array}{l}\text { Business/ } \\
\text { management } \\
\text { (PROGN10) }\end{array}$ & -.068 & .132 & -.044 & -.050 & .075 \\
\hline Health (PROGN11) & -.014 & .052 & -.055 & .018 & -.009 \\
\hline $\begin{array}{l}\text { Vocational// } \\
\text { technical } \\
\text { (PROGN12) }\end{array}$ & -.027 & .034 & -.006 & .012 & .003 \\
\hline
\end{tabular}

Table 57: Equation 5b correlations (continued)

\begin{tabular}{|l|r|r|r|l|l|l|}
\hline & $\begin{array}{l}\text { Hispanic } \\
\text { or Latino }\end{array}$ & Asian & Other & $\begin{array}{l}\text { Do not } \\
\text { know } \\
\text { parent's } \\
\text { education } \\
\text { level }\end{array}$ & $\begin{array}{l}\text { Did not } \\
\text { complete } \\
\text { high } \\
\text { school }\end{array}$ & $\begin{array}{l}\text { High } \\
\text { school } \\
\text { diploma } \\
\text { or } \\
\text { equivalent }\end{array}$ \\
\hline $\begin{array}{l}\text { Institutional merit- } \\
\text { only grants } \\
\text { (IFPVM) }\end{array}$ & -.051 & -.016 & -.024 & -.038 & -.062 & -.084 \\
\hline Age (SA) & .022 & -.069 & .016 & .075 & .216 & .209 \\
\hline Adjusted Gross & -.078 & -.013 & -.016 & -.073 & -.100 & -.167 \\
\hline
\end{tabular}




\begin{tabular}{|l|r|r|r|r|r|r|}
\hline Income (AGI) & & & & & & \\
\hline White (SR1) & -.464 & -.327 & -.206 & -.117 & -.16 & -.045 \\
\hline $\begin{array}{l}\text { Black or African } \\
\text { American (SR2) }\end{array}$ & -.121 & -.085 & -.054 & .073 & .093 & .067 \\
\hline $\begin{array}{l}\text { Hispanic or Latino } \\
\text { (SR3) }\end{array}$ & 1 & -.066 & -.041 & .085 & .128 & .024 \\
\hline Asian (SR4) & -.066 & 1 & .010 & .018 & -.052 & -.006 \\
\hline Other (SR5) & -.041 & -.029 & 1 & -.010 & .019 & .019 \\
\hline $\begin{array}{l}\text { Do not know } \\
\text { parent's education } \\
\text { level (SPEL1) }\end{array}$ & .085 & .010 & -.010 & 1 & -.027 & -.069 \\
\hline $\begin{array}{l}\text { Did not complete } \\
\text { high school } \\
\text { (SPEL2) }\end{array}$ & .128 & .018 & .019 & -.027 & & \\
\hline $\begin{array}{l}\text { High school } \\
\text { diploma or } \\
\text { equivalent (SPEL3) }\end{array}$ & .024 & -.052 & .019 & -.069 & -.110 & -.110 \\
\hline $\begin{array}{l}\text { Vocational or } \\
\text { technical training } \\
\text { (SPEL4) }\end{array}$ & .007 & -.006 & -.011 & -.024 & -.039 & -.100 \\
\hline $\begin{array}{l}\text { Less than two years } \\
\text { of college (SPEL5) }\end{array}$ & .001 & -.016 & -.019 & -.032 & -.051 & -.130 \\
\hline $\begin{array}{l}\text { Associate's degree } \\
\text { (SPEL6) }\end{array}$ & -.002 & -.021 & -.011 & -.035 & -.055 & -.142 \\
\hline $\begin{array}{l}\text { 2 or more years of } \\
\text { college but no } \\
\text { degree (SPEL7) }\end{array}$ & -.030 & -.015 & -.008 & -.028 & -.044 & -.113 \\
\hline $\begin{array}{l}\text { Bachelor's degree } \\
\text { (SPEL8) }\end{array}$ & -.018 & .027 & -.004 & -.073 & -.116 & -.297 \\
\hline $\begin{array}{l}\text { Master's degree or } \\
\text { equivalent (SPEL9) }\end{array}$ & -.064 & .006 & -.015 & -.061 & -.097 & -.250 \\
\hline $\begin{array}{l}\text { First-professional } \\
\text { degree (SPEL10) }\end{array}$ & -.025 & .009 & .026 & -.026 & -.041 & -.106 \\
\hline $\begin{array}{l}\text { Grade point average } \\
\text { (SGPA) }\end{array}$ & -.062 & .010 & -.019 & -.018 & -.003 & -.027 \\
\hline $\begin{array}{l}\text { Undeclared or not } \\
\text { in a degree program } \\
\text { (PROGN1) }\end{array}$ & .017 & .030 & -.021 & .004 & .013 & .001 \\
\hline $\begin{array}{l}\text { Humanities } \\
\text { (PROGN2) }\end{array}$ & -.001 & -.035 & .019 & -.001 & -.025 & -.033 \\
\hline $\begin{array}{l}\text { Social/behavioral } \\
\text { sciences (PROGN3) }\end{array}$ & .003 & .021 & .004 & -.010 & -.025 & -.051 \\
\hline $\begin{array}{l}\text { Life sciences } \\
\text { (PROGN4) }\end{array}$ & & .006 & .042 & -.012 & -.010 & -.020 \\
\hline Physical sciences & & & & & & \\
\hline
\end{tabular}




\begin{tabular}{|l|r|r|r|r|r|r|}
\hline (PROGN5) & & & & & & \\
\hline Math (PROGN6) & -.002 & .012 & -.001 & .006 & .003 & -.013 \\
\hline $\begin{array}{l}\text { Computer/ } \\
\text { information science } \\
\text { (PROGN7) }\end{array}$ & -.010 & .017 & -.003 & -.020 & -.003 & .028 \\
\hline $\begin{array}{l}\text { Engineering } \\
\text { (PROGN8) }\end{array}$ & -.016 & .037 & -.004 & -.001 & -.025 & -.011 \\
\hline $\begin{array}{l}\text { Education } \\
\text { (PROGN9) }\end{array}$ & .008 & -.052 & -.006 & .007 & -.025 & .001 \\
\hline $\begin{array}{l}\text { Business/ } \\
\text { management } \\
\text { (PROGN10) }\end{array}$ & .008 & .005 & -.010 & .001 & .053 & .056 \\
\hline Health (PROGN11) & -.021 & .003 & -.016 & .012 & .017 & .034 \\
\hline $\begin{array}{l}\text { Vocational/ } \\
\text { technical } \\
\text { (PROGN12) }\end{array}$ & -.012 & -.012 & -.010 & .001 & -.012 & -.008 \\
\hline
\end{tabular}

Table 57: Equation 5b Correlations (continued)

\begin{tabular}{|l|r|r|r|r|r|}
\hline & $\begin{array}{l}\text { Vocational } \\
\text { or technical } \\
\text { training }\end{array}$ & $\begin{array}{l}\text { Less than } \\
\text { two years of } \\
\text { college }\end{array}$ & $\begin{array}{l}\text { Associate's } \\
\text { degree }\end{array}$ & $\begin{array}{l}\text { 2 or more } \\
\text { years of } \\
\text { college } \\
\text { but no } \\
\text { degree }\end{array}$ & $\begin{array}{l}\text { Bachelor's } \\
\text { degree }\end{array}$ \\
\hline $\begin{array}{l}\text { Institutional merit- } \\
\text { only grants } \\
\text { (IFPVM) }\end{array}$ & .0215 & .001 & .012 & -.009 & .049 \\
\hline Age (SA) & .038 & -.002 & .003 & .012 & -.121 \\
\hline $\begin{array}{l}\text { Adjusted Gross } \\
\text { Income (SAGI) }\end{array}$ & -.056 & -.045 & -.035 & -.048 & .048 \\
\hline White (SR1) & -.007 & -.004 & .006 & -.002 & .038 \\
\hline $\begin{array}{l}\text { Black or African } \\
\text { American (SR2) }\end{array}$ & .009 & .024 & .009 & .037 & -.048 \\
\hline $\begin{array}{l}\text { Hispanic or Latino } \\
\text { (SR3) }\end{array}$ & .007 & .001 & -.002 & -.030 & -.018 \\
\hline Asian (SR4) & -.016 & -.021 & -.015 & .027 & .006 \\
\hline Other (SR5) & -.011 & -.019 & -.011 & -.008 & -.004 \\
\hline $\begin{array}{l}\text { Do not know } \\
\text { parent's education } \\
\text { level (SPEL1) }\end{array}$ & -.024 & -.032 & -.035 & -.028 & -.073 \\
\hline $\begin{array}{l}\text { Did not complete } \\
\text { high school } \\
\text { (SPEL2) }\end{array}$ & -.039 & -.051 & -.055 & -.044 & -.116 \\
\hline $\begin{array}{l}\text { High school } \\
\text { diploma or }\end{array}$ & -.100 & -.130 & -.142 & -.113 & -.297 \\
\hline
\end{tabular}




\begin{tabular}{|c|c|c|c|c|c|}
\hline equivalent (SPEL3) & & & & & \\
\hline $\begin{array}{l}\text { Vocational or } \\
\text { technical training } \\
\text { (SPEL4) }\end{array}$ & 1 & -.046 & -.050 & -.040 & -.104 \\
\hline $\begin{array}{l}\text { Less than two years } \\
\text { of college (SPEL5) }\end{array}$ & -.046 & 1 & -.065 & -.052 & -.137 \\
\hline $\begin{array}{l}\text { Associate's degree } \\
\text { (SPEL6) }\end{array}$ & -.050 & -.065 & 1 & -.057 & -.149 \\
\hline $\begin{array}{l}2 \text { or more years of } \\
\text { college but no } \\
\text { degree (SPEL7) }\end{array}$ & -.040 & -.052 & -.057 & 1 & -.118 \\
\hline $\begin{array}{l}\text { Bachelor's degree } \\
\text { (SPEL8) }\end{array}$ & -.104 & -.137 & -.149 & -.118 & 1 \\
\hline $\begin{array}{l}\text { Master's degree or } \\
\text { equivalent (SPEL9) }\end{array}$ & -.088 & -.115 & -.125 & -.099 & -.263 \\
\hline $\begin{array}{l}\text { First-professional } \\
\text { degree (SPEL10) }\end{array}$ & -.037 & -.049 & -.053 & -.042 & -.112 \\
\hline $\begin{array}{l}\text { Grade point average } \\
\text { (SGPA) }\end{array}$ & .043 & -.010 & -.028 & -.036 & -.001 \\
\hline $\begin{array}{l}\text { Undeclared or not } \\
\text { in a degree program } \\
(\mathrm{PROGN} 1)\end{array}$ & -.009 & -.021 & -.032 & -.002 & -.021 \\
\hline $\begin{array}{l}\text { Humanities } \\
\text { (PROGN2) }\end{array}$ & .011 & -.003 & -.004 & -.018 & .014 \\
\hline $\begin{array}{l}\text { Social/behavioral } \\
\text { sciences (PROGN3) }\end{array}$ & -.010 & -.015 & -.027 & .002 & -.001 \\
\hline $\begin{array}{l}\text { Life sciences } \\
\text { (PROGN4) }\end{array}$ & -.005 & -.019 & -.013 & -.007 & .010 \\
\hline $\begin{array}{l}\text { Physical sciences } \\
\text { (PROGN5) }\end{array}$ & .009 & .002 & -.021 & -.006 & .014 \\
\hline Math (PROGN6) & -.014 & -.004 & -.005 & -.009 & .018 \\
\hline $\begin{array}{l}\text { Computer/ } \\
\text { information science } \\
(\text { PROGN7) }\end{array}$ & .008 & .014 & -.011 & .007 & -.001 \\
\hline $\begin{array}{l}\text { Engineering } \\
\text { (PROGN8) }\end{array}$ & .003 & -.010 & .003 & 0 & .014 \\
\hline $\begin{array}{l}\text { Education } \\
\text { (PROGN9) }\end{array}$ & -.022 & .041 & .023 & .001 & .010 \\
\hline $\begin{array}{l}\text { Business/ } \\
\text { management } \\
(\mathrm{PROGN} 10) \\
\end{array}$ & .019 & .012 & .008 & .012 & -.014 \\
\hline Health (PROGN11) & .017 & .009 & .022 & -.005 & -.017 \\
\hline $\begin{array}{l}\text { Vocational/ } \\
\text { technical } \\
\text { (PROGN12) }\end{array}$ & -.002 & -.008 & .049 & .021 & .004 \\
\hline
\end{tabular}


Table 57: Equation 5b Correlations (continued)

\begin{tabular}{|l|c|r|r|r|r|}
\hline & $\begin{array}{l}\text { Master's } \\
\text { degree or } \\
\text { equivalent }\end{array}$ & $\begin{array}{l}\text { First- } \\
\text { professional } \\
\text { degree }\end{array}$ & $\begin{array}{l}\text { Grade point } \\
\text { average }\end{array}$ & $\begin{array}{l}\text { Undeclared } \\
\text { or not in a } \\
\text { degree } \\
\text { program }\end{array}$ & Humanities \\
\hline $\begin{array}{l}\text { Institutional merit- } \\
\text { only grants } \\
\text { (IFPVM) }\end{array}$ & .055 & .031 & .129 & -.020 & .016 \\
\hline Age (SA) & -.149 & -.091 & .158 & -.021 & -.064 \\
\hline $\begin{array}{l}\text { Adjusted Gross } \\
\text { Income (SAGI) }\end{array}$ & .153 & .104 & 0.100 & .029 & .017 \\
\hline White (SR1) & .099 & .039 & .160 & .008 & .045 \\
\hline $\begin{array}{l}\text { Black or African } \\
\text { American (SR2) }\end{array}$ & -.075 & -.053 & -.160 & -.0420 & -.044 \\
\hline $\begin{array}{l}\text { Hispanic or Latino } \\
\text { (SR3) }\end{array}$ & -.064 & -.025 & -.062 & .017 & -.001 \\
\hline Asian (SR4) & .009 & .010 & 0.030 & -.0345 & .021 \\
\hline Other (SR5) & -.015 & .026 & -.019 & -.021 & .019 \\
\hline $\begin{array}{l}\text { Do not know } \\
\text { parent's education } \\
\text { level (SPEL1) }\end{array}$ & -.061 & -.026 & -.018 & .0040 & -.001 \\
\hline $\begin{array}{l}\text { Did not complete } \\
\text { high school } \\
\text { (SPEL2) }\end{array}$ & -.097 & -.041 & -.003 & .013 & -.025 \\
\hline $\begin{array}{l}\text { High school } \\
\text { diploma or } \\
\text { equivalent (SPEL3) }\end{array}$ & -.250 & -.106 & -.027 & .001 & -.033 \\
\hline $\begin{array}{l}\text { Vocational or } \\
\text { technical training } \\
\text { (SPEL4) }\end{array}$ & -.088 & -.037 & .043 & -.009 & .011 \\
\hline $\begin{array}{l}\text { Less than two years } \\
\text { of college (SPEL5) }\end{array}$ & -.115 & -.049 & -.010 & -.021 & -.003 \\
\hline $\begin{array}{l}\text { Associate's degree } \\
\text { (SPEL6) }\end{array}$ & -.125 & -.053 & -.028 & -.032 & -.004 \\
\hline $\begin{array}{l}\text { 2 or more years of } \\
\text { college but no } \\
\text { degree (SPEL7) }\end{array}$ & -.099 & -.042 & -.036 & -.002 & -.018 \\
\hline $\begin{array}{l}\text { Bachelor's degree } \\
\text { (SPEL8) }\end{array}$ & -.263 & -.112 & -.001 & -.021 & .014 \\
\hline $\begin{array}{l}\text { Master's degree or } \\
\text { equivalent (SPEL9) }\end{array}$ & 1 & -.094 & .006 & .015 & .019 \\
\hline
\end{tabular}




\begin{tabular}{|l|r|r|r|r|r|}
\hline $\begin{array}{l}\text { First-professional } \\
\text { degree (SPEL10) }\end{array}$ & -.094 & 1 & .051 & .037 & .011 \\
\hline $\begin{array}{l}\text { Grade point average } \\
\text { (SGPA) }\end{array}$ & .006 & .051 & 1 & -.019 & -.001 \\
\hline $\begin{array}{l}\text { Undeclared or not } \\
\text { in a degree program } \\
\text { (PROGN1) }\end{array}$ & .015 & .037 & -.019 & 1 & -.146 \\
\hline $\begin{array}{l}\text { Humanities } \\
\text { (PROGN2) }\end{array}$ & .019 & .011 & -.001 & -.146 & 1 \\
\hline $\begin{array}{l}\text { Social/behavioral } \\
\text { sciences (PROGN3) }\end{array}$ & .052 & .034 & .021 & -.147 & -.140 \\
\hline $\begin{array}{l}\text { Life sciences } \\
\text { (PROGN4) }\end{array}$ & .024 & .042 & -.001 & -.093 & -.089 \\
\hline $\begin{array}{l}\text { Physical sciences } \\
\text { (PROGN5) }\end{array}$ & .015 & .006 & .014 & -.037 & -.035 \\
\hline Math (PROGN6) & -.004 & -.007 & .036 & -.030 & -.029 \\
\hline $\begin{array}{l}\text { Computer/ } \\
\text { information science } \\
\text { (PROGN7) }\end{array}$ & -.024 & -.011 & .018 & -.087 & -.083 \\
\hline $\begin{array}{l}\text { Engineering } \\
\text { (PROGN8) }\end{array}$ & .008 & .007 & -0.030 & -.079 & -.075 \\
\hline $\begin{array}{l}\text { Education } \\
\text { (PROGN9) }\end{array}$ & -.001 & -.009 & .036 & -.106 & -.101 \\
\hline $\begin{array}{l}\text { Business/ } \\
\text { management } \\
\text { (PROGN10) }\end{array}$ & -.043 & -.051 & -.018 & -.205 & -.197 \\
\hline Health (PROGN11) & -.036 & -.029 & .018 & -.106 & -.102 \\
\hline $\begin{array}{l}\text { Vocational/ } \\
\text { technical } \\
\text { (PROGN12) }\end{array}$ & -.009 & -.001 & -.040 & -.039 \\
\hline
\end{tabular}

Table 57: Equation 5b Correlations (continued)

\begin{tabular}{|l|r|r|r|r|r|}
\hline & $\begin{array}{l}\text { Social/ } \\
\text { behavioral } \\
\text { sciences }\end{array}$ & Math & $\begin{array}{l}\text { Life } \\
\text { sciences }\end{array}$ & $\begin{array}{l}\text { Physical } \\
\text { sciences }\end{array}$ & $\begin{array}{l}\text { Computer/ } \\
\text { information } \\
\text { science }\end{array}$ \\
\hline $\begin{array}{l}\text { Institutional merit- } \\
\text { only grants } \\
\text { (IFPVM) }\end{array}$ & .020 & .029 & .101 & .048 & -.045 \\
\hline Age (SA) & -.080 & -.034 & -.101 & -.040 & .069 \\
\hline $\begin{array}{l}\text { Adjusted Gross } \\
\text { Income (SAGI) }\end{array}$ & .034 & -.009 & .046 & .018 & -.025 \\
\hline White (R1) & .011 & .010 & -.006 & .008 & -.034 \\
\hline
\end{tabular}




\begin{tabular}{|l|r|r|r|r|r|}
\hline $\begin{array}{l}\text { Black or African } \\
\text { American (R2) }\end{array}$ & -.032 & -.025 & -.020 & -.007 & .042 \\
\hline $\begin{array}{l}\text { Hispanic or Latino } \\
\text { (R3) }\end{array}$ & .003 & -.002 & .007 & -.024 & -.010 \\
\hline Asian (R4) & 0.014 & .017 & -.006 & .012 & .037 \\
\hline Other (R5) & .004 & -.001 & .039 & .042 & -.003 \\
\hline $\begin{array}{l}\text { Do not know } \\
\text { parent's education } \\
\text { level (SPEL1) }\end{array}$ & -.009 & .006 & .003 & -.012 & -.020 \\
\hline $\begin{array}{l}\text { Did not complete } \\
\text { high school } \\
\text { (SPEL2) }\end{array}$ & -.025 & .003 & -.013 & -.010 & -.003 \\
\hline $\begin{array}{l}\text { High school } \\
\text { diploma or } \\
\text { equivalent (SPEL3) }\end{array}$ & -.051 & -.013 & -.038 & -.020 & .028 \\
\hline $\begin{array}{l}\text { Vocational or } \\
\text { technical training } \\
\text { (SPEL4) }\end{array}$ & -.010 & -.014 & -.005 & .009 & .008 \\
\hline $\begin{array}{l}\text { Less than two years } \\
\text { of college (SPEL5) }\end{array}$ & -.015 & -.004 & -.019 & .002 & .014 \\
\hline $\begin{array}{l}\text { Associate's degree } \\
\text { (SPEL6) }\end{array}$ & -.027 & -.005 & -.013 & -.021 & -.011 \\
\hline $\begin{array}{l}\text { 2 or more years of } \\
\text { college but no } \\
\text { degree (SPEL7) }\end{array}$ & .002 & -.009 & -.007 & -.006 & .007 \\
\hline $\begin{array}{l}\text { Bachelor's degree } \\
\text { (SPEL8) }\end{array}$ & -.001 & .018 & .010 & .014 & -.001 \\
\hline $\begin{array}{l}\text { Master's degree or } \\
\text { equivalent (SPEL9) }\end{array}$ & .052 & -.004 & .024 & .015 & -.024 \\
\hline $\begin{array}{l}\text { First-professional } \\
\text { degree (SPEL10) }\end{array}$ & .034 & -.007 & .042 & .006 & -.011 \\
\hline $\begin{array}{l}\text { Grade point average } \\
\text { (SGPA) }\end{array}$ & .021 & .036 & -.001 & .014 & .018 \\
\hline $\begin{array}{l}\text { Undeclared or not } \\
\text { in a degree program } \\
\text { (PROGN1) }\end{array}$ & -.147 & -.030 & -.093 & -.037 & -.087 \\
\hline $\begin{array}{l}\text { Humanities } \\
\text { (PROGN2) }\end{array}$ & -.140 & -.029 & -.089 & -.035 & -.083 \\
\hline $\begin{array}{l}\text { Social/behavioral } \\
\text { sciences (PROGN3) }\end{array}$ & 1 & -.029 & -.089 & -.035 & -.083 \\
\hline $\begin{array}{l}\text { Life sciences } \\
\text { (PROGN4) }\end{array}$ & -.018 & -.022 & 1 & -.022 & -.052 \\
\hline $\begin{array}{l}\text { Physical sciences } \\
\text { (PROGN5) }\end{array}$ & & & & & -.021 \\
\hline Math (PROGN6) & & & & & -.017 \\
\hline
\end{tabular}




\begin{tabular}{|l|c|c|c|c|r|}
\hline $\begin{array}{l}\text { Computer/ } \\
\text { information science } \\
\text { (PROGN7) }\end{array}$ & -.083 & -.017 & -.052 & -.021 & 1 \\
\hline $\begin{array}{l}\text { Engineering } \\
\text { (PROGN8) }\end{array}$ & -.075 & -.016 & -.048 & -.019 & -.045 \\
\hline $\begin{array}{l}\text { Education } \\
\text { (PROGN9) }\end{array}$ & -.101 & -.021 & -.064 & -.025 & -.060 \\
\hline $\begin{array}{l}\text { Business/ } \\
\text { management } \\
\text { (PROGN10) }\end{array}$ & -.197 & -.041 & -.124 & -.049 & -.116 \\
\hline Health (PROGN11) & -.102 & -.021 & -.065 & -.026 & -.060 \\
\hline $\begin{array}{l}\text { Vocational/ } \\
\text { technical } \\
\text { (PROGN12) }\end{array}$ & -.039 & -.008 & -.025 & -.010 & -.023 \\
\hline
\end{tabular}

Table 57: Equation 5b Correlations (continued)

\begin{tabular}{|c|c|c|c|c|c|}
\hline & Engineering & Education & $\begin{array}{l}\text { Business/ } \\
\text { management }\end{array}$ & Health & $\begin{array}{l}\text { Vocational/ } \\
\text { technical }\end{array}$ \\
\hline $\begin{array}{l}\text { Institutional merit- } \\
\text { only grants } \\
\text { (IFPVM) }\end{array}$ & .020 & .035 & -.068 & -.014 & -.027 \\
\hline Age (SA) & -.044 & -.014 & .132 & .052 & .034 \\
\hline $\begin{array}{l}\text { Adjusted Gross } \\
\text { Income (SAGI) }\end{array}$ & .033 & .007 & -.044 & -.055 & -.006 \\
\hline White (R1) & .003 & .059 & -.050 & .018 & .012 \\
\hline $\begin{array}{l}\text { Black or African } \\
\text { American (R2) }\end{array}$ & -.019 & -.044 & .075 & -.009 & .003 \\
\hline $\begin{array}{l}\text { Hispanic or Latino } \\
\text { (R3) }\end{array}$ & -.016 & .008 & .008 & -.021 & -.012 \\
\hline Asian (R4) & -.052 & .005 & .003 & -.012 & .001 \\
\hline Other (R5) & -.004 & -.006 & -.010 & -.016 & -.010 \\
\hline $\begin{array}{l}\text { Do not know } \\
\text { parent's education } \\
\text { level (SPEL1) }\end{array}$ & -.001 & .007 & .001 & .012 & .001 \\
\hline $\begin{array}{l}\text { Did not complete } \\
\text { high school } \\
\text { (SPEL2) }\end{array}$ & -.025 & -.025 & .053 & .017 & -.012 \\
\hline $\begin{array}{l}\text { High school } \\
\text { diploma or } \\
\text { equivalent (SPEL3) }\end{array}$ & -.011 & .001 & .056 & .034 & -.008 \\
\hline $\begin{array}{l}\text { Vocational or } \\
\text { technical training } \\
\text { (SPEL4) }\end{array}$ & .003 & -.022 & .019 & .017 & -.002 \\
\hline
\end{tabular}




\begin{tabular}{|c|c|c|c|c|c|}
\hline $\begin{array}{l}\text { Less than two years } \\
\text { of college (SPEL5) }\end{array}$ & -.009 & .041 & .012 & .009 & -.008 \\
\hline $\begin{array}{l}\text { Associate's degree } \\
\text { (SPEL6) }\end{array}$ & .003 & .023 & .008 & .022 & .049 \\
\hline $\begin{array}{l}2 \text { or more years of } \\
\text { college but no } \\
\text { degree (SPEL7) }\end{array}$ & .001 & .001 & .012 & -.005 & .021 \\
\hline $\begin{array}{l}\text { Bachelor's degree } \\
\text { (SPEL8) }\end{array}$ & .014 & .010 & -.014 & -.017 & .004 \\
\hline $\begin{array}{l}\text { Master's degree or } \\
\text { equivalent (SPEL9) }\end{array}$ & .008 & -.001 & -.043 & -.036 & -.016 \\
\hline $\begin{array}{l}\text { First-professional } \\
\text { degree (SPEL10) }\end{array}$ & .007 & -.009 & -.051 & -.029 & -.009 \\
\hline $\begin{array}{l}\text { Grade point average } \\
\text { (SGPA) }\end{array}$ & -.030 & .036 & -.018 & .018 & -.001 \\
\hline $\begin{array}{l}\text { Undeclared or not } \\
\text { in a degree program } \\
(\mathrm{PROGN} 1)\end{array}$ & -.079 & -.106 & -.205 & -.106 & -.040 \\
\hline $\begin{array}{l}\text { Humanities } \\
(\text { PROGN2) }\end{array}$ & -.075 & -.101 & -.197 & -.102 & -.039 \\
\hline $\begin{array}{l}\text { Social/behavioral } \\
\text { sciences (PROGN3) }\end{array}$ & -.075 & -.101 & -.197 & -.102 & -.039 \\
\hline $\begin{array}{l}\text { Life sciences } \\
\text { (PROGN4) }\end{array}$ & -.048 & -.064 & -.124 & -.065 & -.025 \\
\hline $\begin{array}{l}\text { Physical sciences } \\
\text { (PROGN5) }\end{array}$ & -.019 & -.025 & -.049 & -.026 & -.010 \\
\hline Math (PROGN6) & -.016 & -.021 & -.041 & -.021 & -.008 \\
\hline $\begin{array}{l}\text { Computer/ } \\
\text { information science } \\
\text { (PROGN7) }\end{array}$ & -.045 & -.060 & -.116 & -.060 & -.023 \\
\hline $\begin{array}{l}\text { Engineering } \\
\text { (PROGN8) }\end{array}$ & 1 & -.054 & -.106 & -.055 & -.021 \\
\hline $\begin{array}{l}\text { Education } \\
\text { (PROGN9) } \\
\end{array}$ & -.054 & 1 & -.142 & -.074 & -.028 \\
\hline $\begin{array}{l}\text { Business/ } \\
\text { management } \\
(\text { PROGN10) } \\
\end{array}$ & -.106 & -.142 & 1 & -.143 & -.054 \\
\hline Health (PROGN11) & -.055 & -.074 & -.143 & 1 & -.028 \\
\hline $\begin{array}{l}\text { Vocational/ } \\
\text { technical } \\
\text { (PROGN12) }\end{array}$ & -.021 & -.028 & -.054 & -.028 & 1 \\
\hline
\end{tabular}


This analysis identified significant relationships between the amount of institutional merit-based financial grant aid paid per student by private institutions and students' ages and the adjusted gross income of their parents or the students if they were independent. In addition relationships were noted between the dependent variable and the education levels of parents who did not complete high school; received a high school diploma or equivalent; received vocational or technical training; had less than two years of college; held Associate's degrees; had two years of college but no degree; and received Bachelor's degrees. Finally, the analysis indicates that a relationship exists between the dependent variable and students' grade point averages as well as students who majored in Life Sciences. These relationships are represented by the following econometric equation:

IFPVM $_{i}=+-101.259$ SA + 0.002SAGI + 706.889SPEL2 + 446.145SPEL3 + 1066.287SPEL4 + 590.934SPEL5 + 792.84SPEL6 + 589.909SPEL 7 + 629.544SPEL8 + 557.297SPEL9 + 8.403SGPA + 1120.855PROGN4 + 868.004

Research Question 5c: Do the amounts paid for institutional merit-based financial grant aid paid per student by public institutions differ significantly from the amounts paid for institutional merit-based financial grant aid paid per student by private institutions? Research Question 5c relates to Hypothesis $\left(\mathrm{H}_{5 \mathrm{c}}\right)$, that the amount of institutional merit-based financial grant aid paid per student by public institutions is less than or equal to the amount of institutional merit-based financial grant aid paid per student by private institutions.

As described in Chapter 3, Equation 5c relates to Research Question 5c and Hypothesis 5c:

IFPBM $\leq$ IFPVM 
The data used for the means comparison are displayed in Table 58. The following formula was used to calculate the $t$ value:

$$
t_{d f}=\frac{\left|\bar{x}_{A}-\bar{x}_{B}\right|}{\sqrt{\hat{V}_{A}+\hat{V}_{B}}}
$$

The means for the two groups that were compared are represented by $\bar{x}_{A}$ and $\bar{x}_{B}$. The respective squared standard errors associated with the means are represented by $\hat{V}_{A}$ and $\hat{V}_{B}$.

The $t$ value for the comparison of the two means was 12.32. Because the test statistic exceeds the critical value of \pm 1.96 , the difference between the two means is statistically significant.

Table 58: Equation 5c group statistics

\begin{tabular}{|l|c|r|}
\hline & Mean & Standard Error \\
\hline Public Institutions & 144.0218 & 9.2173 \\
\hline Private Institutions & 1531.363 & 112.2281 \\
\hline
\end{tabular}

Research Question 5d: Is there a significant relationship between institutional needbased financial grant aid paid per student by public institutions, student characteristics, and academic programs? Research Question 5d relates to Hypothesis $\left(\mathrm{H}_{5 \mathrm{~d}}\right)$, that there is no significant relationship between institutional need-based financial grant aid paid per student by public institutions, student characteristics, and academic programs. As described in Chapter 3, Equation 5d relates to Research Question 5d and Hypothesis 5d:

$$
\mathrm{IFPBN}_{\mathrm{i}}=\mathrm{SA}_{\mathrm{i}}+\mathrm{SAGI}_{\mathrm{i}}+\mathrm{SR}_{\mathrm{i}}+\mathrm{SG}_{\mathrm{i}}+\mathrm{SPEL}_{\mathrm{i}}+\mathrm{SGPA}_{\mathrm{i}}+\mathrm{SVA}_{\mathrm{i}}+\mathrm{LOC}_{\mathrm{i}}+\mathrm{PROGN}_{\mathrm{i}}
$$

The significance scores for this equation are displayed in Table 59. The NCES' DAS was used to perform a weighted least squares computation using NPSAS: 04 data. 
Table 59: Equation 5d hypothesis testing results

\begin{tabular}{|l|r|r|r|r|r|}
\hline & Wald $F$ & Num. DF & Denom. DF & Commonality & $\begin{array}{l}\text { Probability } \\
F\end{array}$ \\
\hline Overall Fit & 19.651 & 34 & 31 & & 0.001 \\
\hline Age (SA) & 163.741 & 1 & 64 & 0.005 & 0.001 \\
\hline $\begin{array}{l}\text { Adjusted Gross } \\
\text { Income (SAGI) }\end{array}$ & 87.314 & 1 & 64 & 0.003 & 0.001 \\
\hline Race (SR) & 16.978 & 5 & 60 & 0.005 & 0.001 \\
\hline Gender (SG) & 0.0400 & 1 & 64 & 0.000 & 0.843 \\
\hline $\begin{array}{l}\text { Parent's highest } \\
\text { education level } \\
\text { (SPEL) }\end{array}$ & 2.121 & 10 & 55 & 0.001 & 0.038 \\
\hline $\begin{array}{l}\text { Grade point average } \\
\text { (SGPA) }\end{array}$ & 65.27 & 1 & 64 & 0.003 & 0.001 \\
\hline $\begin{array}{l}\text { Attend institution in } \\
\text { state of legal } \\
\text { residence (LOC) }\end{array}$ & 6.362 & 2 & 63 & 0.001 & 0.003 \\
\hline $\begin{array}{l}\text { Veteran status } \\
\text { (SVA) }\end{array}$ & 6.888 & 1 & 64 & 0.000 & 0.011 \\
\hline Program (PROGN) & 5.716 & 12 & 53 & 0.002 & 0.001 \\
\hline
\end{tabular}

The variable Gender (SG) was not significant. Because it was not significant, a second computation was completed without this variable. The significance scores for this computation are displayed in Table 60. All the variables in this equation were significant. The regression coefficients from this equation are displayed in Table 61. The coefficients for the variables Age, Adjusted gross income, Asian, Did not complete high school, Grade point average, Not a veteran, Life sciences, and Vocational/technical programs were significant. The coefficient of determination was .022. From this statistic, we may conclude that 2.2 percent of the variance in institutional need-based financial grant aid per student paid by public institutions is explained by the independent variables in this equation.

Table 60: Equation 5d hypothesis testing results second calculation

\begin{tabular}{|l|r|r|r|r|r|}
\hline & Wald $F$ & Num. DF & Denom. DF & Commonality & \multicolumn{2}{l|}{$\begin{array}{l}\text { Probability } \\
F\end{array}$} \\
\hline Overall Fit & 15.652 & 33 & 32 & & 0.001 \\
\hline Age (SA) & 160.939 & 1 & 64 & 0.005 & 0.001 \\
\hline
\end{tabular}




\begin{tabular}{|l|r|r|r|r|r|}
\hline $\begin{array}{l}\text { Adjusted Gross } \\
\text { Income (SAGI) }\end{array}$ & 86.802 & 1 & 64 & 0.003 & 0.001 \\
\hline Race (SR) & 17.405 & 5 & 60 & 0.005 & 0.001 \\
\hline $\begin{array}{l}\text { Parent's highest } \\
\text { education level } \\
\text { (SPEL) }\end{array}$ & 2.132 & 10 & 55 & 0.001 & 0.037 \\
\hline $\begin{array}{l}\text { Grade point average } \\
\text { (SGPA) }\end{array}$ & 61.831 & 1 & 64 & 0.003 & 0.001 \\
\hline $\begin{array}{l}\text { Attend institution in } \\
\text { state of legal } \\
\text { residence (LOC) }\end{array}$ & 6.344 & 2 & 63 & 0.001 & 0.003 \\
\hline Veteran status (SVA) & 7.234 & 1 & 64 & 0 & 0.009 \\
\hline Program (PROGN) & 5.671 & 12 & 53 & 0.002 & 0.001 \\
\hline
\end{tabular}

Table 61: Equation 5d estimated full sample regression coefficients

\begin{tabular}{|c|c|c|c|c|}
\hline & $b$ & s.e. & $t$ & Probability $t$ \\
\hline Intercept & 219.338 & 189.702 & 1.156 & 0.252 \\
\hline Age (SA) & -11.869 & 0.936 & -12.686 & 0.001 \\
\hline Adjusted Gross Income (SAGI) & -0.001 & 0.000 & -9.317 & 0.001 \\
\hline \multicolumn{5}{|l|}{ Race } \\
\hline White (R1) & -84.827 & 66.609 & -1.274 & 0.207 \\
\hline Black or African American (R2) & 62.802 & 80.996 & 0.775 & 0.441 \\
\hline Hispanic or Latino (R3) & 82.866 & 64.524 & 1.284 & 0.204 \\
\hline Asian (R4) & 177.107 & 75.369 & 2.350 & 0.022 \\
\hline Other (R5) & -74.913 & 65.363 & -1.146 & 0.256 \\
\hline \multicolumn{5}{|l|}{ vs. More than one race } \\
\hline \multicolumn{5}{|l|}{ Parent's highest education level } \\
\hline $\begin{array}{l}\text { Do not know parent's education level } \\
\text { (SPEL1) }\end{array}$ & -10.773 & 58.941 & -0.183 & 0.856 \\
\hline Did not complete high school (SPEL2) & 169.581 & 45.908 & 3.694 & 0.001 \\
\hline $\begin{array}{l}\text { High school diploma or equivalent } \\
\text { (SPEL3) }\end{array}$ & 30.439 & 36.135 & 0.842 & 0.403 \\
\hline $\begin{array}{l}\text { Vocational or technical training } \\
\text { (SPEL4) }\end{array}$ & 22.595 & 57.761 & 0.391 & 0.697 \\
\hline $\begin{array}{l}\text { Less than two years of college } \\
\text { (SPEL5) }\end{array}$ & 48.447 & 44.858 & 1.080 & 0.284 \\
\hline Associate's degree (SPEL6) & -23.433 & 34.47 & -0.68 & 0.499 \\
\hline $\begin{array}{l}2 \text { or more years of college but no } \\
\text { degree (SPEL7) }\end{array}$ & 32.309 & 56.24 & 0.574 & 0.568 \\
\hline Bachelor's degree (SPEL8) & 22.803 & 43.299 & 0.527 & 0.600 \\
\hline Master's degree or equivalent (SPEL9) & 49.899 & 42.715 & 1.168 & 0.247 \\
\hline First-professional degree (SPEL10) & -36.365 & 67.02 & -0.543 & 0.589 \\
\hline vs. Doctoral degree or equivalent & & & & \\
\hline
\end{tabular}




\begin{tabular}{|l|r|r|r|r|}
\hline (SPEL11) & & & & \\
\hline Grade point average (SGPA) & 0.854 & 0.109 & 7.863 & 0.001 \\
\hline $\begin{array}{l}\text { Attend institution in state of legal } \\
\text { residence }\end{array}$ & & & & \\
\hline Yes (LOC1) & 33.604 & 213.174 & 0.158 & 0.875 \\
\hline No (LOC2) & 160.431 & 221.887 & 0.723 & 0.472 \\
\hline vs. Foreign or international student & & & & \\
\hline Veteran status & & & & \\
\hline Not a veteran (SVA) & 70.952 & 26.379 & 2.690 & 0.009 \\
\hline vs. Veteran & & & & \\
\hline Field of study: undergraduate (12 cat) & & & & 0.688 \\
\hline $\begin{array}{l}\text { Undeclared or not in a degree program } \\
\text { (PROG1) }\end{array}$ & -13.806 & 34.273 & -0.403 & \\
\hline Humanities (PROG2) & 57.079 & 44.561 & 1.281 & 0.205 \\
\hline Social/behavioral sciences (PROG3) & 75.461 & 46.163 & 1.635 & 0.107 \\
\hline Life sciences (PROG4) & 128.025 & 49.298 & 2.597 & 0.012 \\
\hline Physical sciences (PROG5) & 144.925 & 116.74 & 1.241 & 0.219 \\
\hline Math (PROG6) & 165.361 & 153.83 & 1.075 & 0.286 \\
\hline $\begin{array}{l}\text { Computer/information science } \\
\text { (PROG7) }\end{array}$ & -14.200 & 41.263 & -0.344 & 0.732 \\
\hline Engineering (PROG8) & 45.435 & 44.05 & 1.031 & 0.306 \\
\hline Education (PROG9) & -47.159 & 27.757 & -1.699 & 0.094 \\
\hline Business/management (PROG10) & -18.861 & 26.059 & -0.724 & 0.472 \\
\hline Health (PROG11) & 20.012 & 51.286 & 0.39 & 0.698 \\
\hline Vocational/technical (PROG12) & -96.727 & 47.855 & -2.021 & 0.047 \\
\hline Vs. Other technical/professional & & & & \\
\hline
\end{tabular}

The correlations for this equation are displayed in Table 62 .

Table 62: Equation 5d correlations

\begin{tabular}{|l|l|l|l|r|r|r|}
\hline & $\begin{array}{l}\text { Institutional } \\
\text { need-based } \\
\text { grants }\end{array}$ & Age & $\begin{array}{l}\text { Adjusted } \\
\text { Gross } \\
\text { Income } \\
\text { (AGI) }\end{array}$ & White & $\begin{array}{l}\text { Black or } \\
\text { African } \\
\text { American }\end{array}$ & $\begin{array}{l}\text { Hispanic } \\
\text { or Latino }\end{array}$ \\
\hline $\begin{array}{l}\text { Institutional } \\
\text { need-based } \\
\text { grants } \\
\text { (IFPBN) }\end{array}$ & 1 & -.063 & -.056 & -.071 & .029 & .039 \\
\hline Age (SA) & -.063 & 1 & -.181 & -.038 & .067 & .001 \\
\hline
\end{tabular}




\begin{tabular}{|c|c|c|c|c|c|c|}
\hline $\begin{array}{l}\text { Adjusted } \\
\text { Gross Income } \\
\text { (SAGI) }\end{array}$ & -.056 & -.181 & 1 & .171 & -.132 & -.082 \\
\hline White (R1) & -.071 & -.038 & .171 & 1 & -.532 & -.463 \\
\hline $\begin{array}{l}\text { Black or } \\
\text { African } \\
\text { American } \\
\text { (R2) }\end{array}$ & .029 & .067 & -.132 & -.532 & 1 & -.102 \\
\hline $\begin{array}{l}\text { Hispanic or } \\
\text { Latino (R3) }\end{array}$ & .039 & .001 & -.082 & -.463 & -.102 & 1 \\
\hline Asian (R4) & .057 & -.036 & -.044 & -.392 & -.086 & -.075 \\
\hline Other (R5) & -.007 & .032 & -.030 & -.256 & -.057 & -.049 \\
\hline $\begin{array}{l}\text { Do not know } \\
\text { parent's } \\
\text { education } \\
\text { level (SPEL1) }\end{array}$ & -.001 & .069 & -.065 & -.103 & .036 & .040 \\
\hline $\begin{array}{l}\text { Did not } \\
\text { complete high } \\
\text { school } \\
\text { (SPEL2) }\end{array}$ & .030 & .151 & -.106 & -.163 & .036 & .181 \\
\hline $\begin{array}{l}\text { High school } \\
\text { diploma or } \\
\text { equivalent } \\
\text { (SPEL3) }\end{array}$ & -.004 & .125 & -.154 & -.033 & .053 & .025 \\
\hline $\begin{array}{l}\text { Vocational or } \\
\text { technical } \\
\text { training } \\
\text { (SPEL4) } \\
\end{array}$ & -.002 & .026 & -.018 & .009 & .001 & .004 \\
\hline $\begin{array}{l}\text { Less than two } \\
\text { years of } \\
\text { college } \\
\text { (SPEL5) }\end{array}$ & .005 & -.004 & $\begin{array}{l}.044 \\
\end{array}$ & -.005 & .016 & .015 \\
\hline $\begin{array}{l}\text { Associate's } \\
\text { degree } \\
\text { (SPEL6) }\end{array}$ & -.013 & -.004 & $\begin{array}{l}-.020 \\
\end{array}$ & -.008 & .021 & -.011 \\
\hline $\begin{array}{l}2 \text { or more } \\
\text { years of } \\
\text { college but no } \\
\text { degree } \\
\text { (SPEL7) }\end{array}$ & .002 & .011 & $\begin{array}{l}-.039 \\
\end{array}$ & -.012 & .040 & -.003 \\
\hline $\begin{array}{l}\text { Bachelor's } \\
\text { degree } \\
\text { (SPEL8) }\end{array}$ & -.005 & -.100 & .096 & .067 & -.053 & -.055 \\
\hline
\end{tabular}




\begin{tabular}{|c|c|c|c|c|c|c|}
\hline $\begin{array}{l}\text { Master's } \\
\text { degree or } \\
\text { equivalent } \\
\text { (SPEL9) }\end{array}$ & .009 & -.098 & .125 & .067 & -.048 & -0.050 \\
\hline $\begin{array}{l}\text { First- } \\
\text { professional } \\
\text { degree } \\
\text { (SPEL10) }\end{array}$ & -.008 & -.033 & .058 & .015 & -.0120 & -.015 \\
\hline $\begin{array}{l}\text { Grade point } \\
\text { average } \\
\text { (SGPA) }\end{array}$ & .035 & .133 & .048 & .121 & -.132 & -.054 \\
\hline $\begin{array}{l}\text { Attend } \\
\text { institution in } \\
\text { state of legal } \\
\text { residence } \\
=\text { Yes (LOC1) }\end{array}$ & -.036 & .095 & -.076 & .028 & -.039 & .043 \\
\hline $\begin{array}{l}\text { Attend } \\
\text { institution in } \\
\text { state of legal } \\
\text { residence=No } \\
\text { (LOC2) }\end{array}$ & .033 & -.097 & .099 & .025 & .033 & -.048 \\
\hline $\begin{array}{l}\text { Veteran } \\
\text { status=Not a } \\
\text { veteran } \\
(\text { SVA }) \\
\end{array}$ & .021 & -.202 & .056 & .011 & -.021 & .007 \\
\hline $\begin{array}{l}\text { Undeclared or } \\
\text { not in a } \\
\text { degree } \\
\text { program } \\
\text { (PROGN1) }\end{array}$ & -.016 & .001 & .010 & -.002 & -.034 & .010 \\
\hline $\begin{array}{l}\text { Humanities } \\
\text { (PROGN2) }\end{array}$ & .011 & .008 & -.008 & .017 & -.038 & .016 \\
\hline $\begin{array}{l}\text { Social/ } \\
\text { behavioral } \\
\text { sciences } \\
\text { (PROGN3) }\end{array}$ & .021 & -.017 & -.011 & -.012 & .011 & .009 \\
\hline $\begin{array}{l}\text { Life sciences } \\
\text { (PROGN4) }\end{array}$ & .032 & -.047 & .002 & -.004 & -.009 & -.005 \\
\hline $\begin{array}{l}\text { Physical } \\
\text { sciences } \\
\text { (PROGN5) }\end{array}$ & .013 & -.004 & -.004 & .003 & -.009 & -.008 \\
\hline $\begin{array}{l}\text { Math } \\
\text { (PROGN6) }\end{array}$ & .014 & -.004 & -.001 & -.011 & -.012 & .015 \\
\hline
\end{tabular}




\begin{tabular}{|l|r|r|r|r|r|r|}
\hline $\begin{array}{l}\text { Computer/ } \\
\text { information } \\
\text { science } \\
\text { (PROGN7) }\end{array}$ & -.007 & .018 & -.006 & -.025 & .023 & -.022 \\
\hline $\begin{array}{l}\text { Engineering } \\
\text { (PROGN8) }\end{array}$ & .009 & -.041 & .031 & -.008 & .002 & -.013 \\
\hline $\begin{array}{l}\text { Education } \\
\text { (PROGN9) }\end{array}$ & -.023 & .023 & -.014 & .056 & -.023 & .001 \\
\hline $\begin{array}{l}\text { Business/ } \\
\text { management } \\
\text { (PROGN10) }\end{array}$ & -.016 & .016 & .005 & -.033 & .040 & -.010 \\
\hline $\begin{array}{l}\text { Health } \\
\text { (PROGN11) }\end{array}$ & -.001 & .038 & -.019 & .010 & .003 & -.006 \\
\hline $\begin{array}{l}\text { Vocational } \\
\text { /technical } \\
\text { (PROGN12) }\end{array}$ & -.013 & .012 & .001 & .022 & -0.025 & -.004 \\
\hline
\end{tabular}

Table 62: Equation 5d correlations (continued)

\begin{tabular}{|c|c|c|c|c|c|c|}
\hline & Asian & Other & $\begin{array}{l}\text { Do not } \\
\text { know } \\
\text { parent's } \\
\text { education } \\
\text { level }\end{array}$ & $\begin{array}{l}\text { Did not } \\
\text { complete } \\
\text { high } \\
\text { school }\end{array}$ & $\begin{array}{l}\text { High } \\
\text { school } \\
\text { diploma } \\
\text { or } \\
\text { equivalent }\end{array}$ & $\begin{array}{l}\text { Vocational or } \\
\text { technical } \\
\text { training }\end{array}$ \\
\hline $\begin{array}{l}\text { Institutional } \\
\text { need-based } \\
\text { grants } \\
\text { (IFPBN) }\end{array}$ & .057 & -.007 & -.001 & .0300 & -.004 & -.002 \\
\hline Age (SA) & -.036 & .032 & .069 & .151 & .125 & .026 \\
\hline $\begin{array}{l}\text { Adjusted } \\
\text { Gross Income } \\
\text { (SAGI) }\end{array}$ & -.044 & -.030 & -.065 & -.106 & -.154 & -.018 \\
\hline White (R1) & -.392 & -.256 & -.103 & -.163 & -.033 & .009 \\
\hline $\begin{array}{l}\text { Black or } \\
\text { African } \\
\text { American } \\
\text { (R2) }\end{array}$ & -.086 & -.057 & .036 & .036 & .053 & .001 \\
\hline $\begin{array}{l}\text { Hispanic or } \\
\text { Latino (R3) }\end{array}$ & -.075 & -.049 & .040 & .181 & .025 & .004 \\
\hline Asian (R4) & 1 & -.042 & .085 & .055 & -.015 & -.014 \\
\hline Other (R5) & -.042 & 1 & .026 & .023 & -.009 & -.014 \\
\hline
\end{tabular}




\begin{tabular}{|c|c|c|c|c|c|c|}
\hline $\begin{array}{l}\text { Do not know } \\
\text { parent's } \\
\text { education } \\
\text { level (SPEL1) }\end{array}$ & .085 & .026 & 1 & -.026 & -.069 & -.025 \\
\hline $\begin{array}{l}\text { Did not } \\
\text { complete high } \\
\text { school } \\
\text { (SPEL2) }\end{array}$ & .055 & .023 & -.026 & 1 & -.107 & -.039 \\
\hline $\begin{array}{l}\text { High school } \\
\text { diploma or } \\
\text { equivalent } \\
\text { (SPEL3) }\end{array}$ & -.015 & -.009 & -.069 & -.107 & 1 & -.104 \\
\hline $\begin{array}{l}\text { Vocational or } \\
\text { technical } \\
\text { training } \\
\text { (SPEL4) }\end{array}$ & -.014 & -.014 & -.025 & -.039 & -.104 & 1 \\
\hline $\begin{array}{l}\text { Less than two } \\
\text { years of } \\
\text { college } \\
\text { (SPEL5) }\end{array}$ & -.0233 & -.008 & -.035 & -.054 & -.145 & -.053 \\
\hline $\begin{array}{l}\text { Associate's } \\
\text { degree } \\
\text { (SPEL6) } \\
\end{array}$ & -.005 & -.009 & -.037 & -.056 & -.150 & -.055 \\
\hline $\begin{array}{l}2 \text { or more } \\
\text { years of } \\
\text { college but no } \\
\text { degree } \\
\text { (SPEL7) }\end{array}$ & -.019 & -.021 & -.028 & -.044 & -.116 & -.043 \\
\hline $\begin{array}{l}\text { Bachelor's } \\
\text { degree } \\
\text { (SPEL8) } \\
\end{array}$ & -.009 & .006 & -.077 & -.118 & -.316 & -.116 \\
\hline $\begin{array}{l}\text { Master's } \\
\text { degree or } \\
\text { equivalent } \\
\text { (SPEL9) }\end{array}$ & -.009 & .009 & -.059 & -.090 & -.241 & -.088 \\
\hline $\begin{array}{l}\text { First- } \\
\text { professional } \\
\text { degree } \\
\text { (SPEL10) }\end{array}$ & .011 & .001 & -.021 & -.032 & -.086 & -.032 \\
\hline $\begin{array}{l}\text { Grade point } \\
\text { average } \\
\text { (SGPA) }\end{array}$ & .016 & -.009 & -.027 & -.004 & -.045 & .025 \\
\hline
\end{tabular}




\begin{tabular}{|c|c|c|c|c|c|c|}
\hline $\begin{array}{l}\text { Attend } \\
\text { institution in } \\
\text { state of legal } \\
\text { residence=Ye } \\
\text { s (LOC1) }\end{array}$ & -.064 & .014 & .010 & .032 & .040 & .020 \\
\hline $\begin{array}{l}\text { Attend } \\
\text { institution in } \\
\text { state of legal } \\
\text { residence=No } \\
\text { (LOC2) }\end{array}$ & -.020 & -.021 & -.019 & -.040 & -.039 & -.011 \\
\hline $\begin{array}{l}\text { Veteran } \\
\text { status=Not a } \\
\text { veteran } \\
(\mathrm{SVA})\end{array}$ & .012 & -.021 & -.038 & -.014 & -.039 & -.012 \\
\hline $\begin{array}{l}\text { Undeclared or } \\
\text { not in a } \\
\text { degree } \\
\text { program } \\
\text { (PROGN1) }\end{array}$ & .013 & .028 & -.002 & .009 & .006 & -.001 \\
\hline $\begin{array}{l}\text { Humanities } \\
\text { (PROGN2) }\end{array}$ & -.026 & .008 & .006 & -.011 & -.007 & -.004 \\
\hline $\begin{array}{l}\text { Social/ } \\
\text { behavioral } \\
\text { sciences } \\
\text { (PROGN3) }\end{array}$ & .002 & -.009 & -.003 & -.003 & -.009 & -.014 \\
\hline $\begin{array}{l}\text { Life sciences } \\
\text { (PROGN4) }\end{array}$ & .023 & .005 & -.015 & -.021 & -.014 & .007 \\
\hline $\begin{array}{l}\text { Physical } \\
\text { sciences } \\
\text { (PROGN5) } \\
\end{array}$ & .006 & -.005 & .011 & -.015 & -.006 & -.009 \\
\hline $\begin{array}{l}\text { Math } \\
(\text { PROGN6) }\end{array}$ & .028 & -.011 & -.002 & .012 & -.004 & .005 \\
\hline $\begin{array}{l}\text { Computer/ } \\
\text { information } \\
\text { science } \\
\text { (PROGN7) }\end{array}$ & .047 & .001 & .010 & -.010 & -.001 & .013 \\
\hline $\begin{array}{l}\text { Engineering } \\
\text { (PROGN8) }\end{array}$ & .026 & -.006 & -.013 & -.011 & -.038 & -.002 \\
\hline $\begin{array}{l}\text { Education } \\
\text { (PROGN9) }\end{array}$ & -.060 & -.020 & .001 & .007 & .025 & -.008 \\
\hline $\begin{array}{l}\text { Business/ } \\
\text { management } \\
(\text { PROGN10) }\end{array}$ & .031 & .008 & .011 & .013 & .010 & -.001 \\
\hline $\begin{array}{l}\text { Health } \\
\text { (PROGN11) }\end{array}$ & -.011 & -.001 & .003 & .023 & .008 & .021 \\
\hline
\end{tabular}




\begin{tabular}{|l|l|l|l|l|l|l|}
\hline $\begin{array}{l}\text { Vocational/te } \\
\text { chnical } \\
\text { (PROGN12) }\end{array}$ & -.003 & -.003 & -.002 & .001 & .005 & -.004 \\
\hline
\end{tabular}

Table 62: Equation 5d correlations (continued)

\begin{tabular}{|c|c|c|c|c|c|c|}
\hline & $\begin{array}{l}\text { Less } \\
\text { than } \\
\text { two } \\
\text { years of } \\
\text { college }\end{array}$ & $\begin{array}{l}\text { Associate's } \\
\text { degree }\end{array}$ & $\begin{array}{l}2 \text { or more } \\
\text { years of } \\
\text { college } \\
\text { but no } \\
\text { degree }\end{array}$ & $\begin{array}{l}\text { Bachelor's } \\
\text { degree }\end{array}$ & $\begin{array}{l}\text { Master's } \\
\text { degree or } \\
\text { equivalent }\end{array}$ & $\begin{array}{l}\text { First- } \\
\text { professional } \\
\text { degree }\end{array}$ \\
\hline $\begin{array}{l}\text { Institutional } \\
\text { need-based } \\
\text { grants } \\
\text { (IFPBN) } \\
\end{array}$ & .005 & -.013 & .002 & -.005 & .009 & -.008 \\
\hline Age (SA) & -.004 & -.004 & .011 & -.1003 & -.0979 & -.033 \\
\hline $\begin{array}{l}\text { Adjusted } \\
\text { Gross Income } \\
\text { (SAGI) }\end{array}$ & -.044 & -.0199 & -.0388 & .0955 & .1248 & .0583 \\
\hline White (R1) & -.005 & -.0075 & -.0122 & .0667 & .0668 & .0148 \\
\hline $\begin{array}{l}\text { Black or } \\
\text { African } \\
\text { American } \\
\text { (R2) }\end{array}$ & .016 & .0212 & .0403 & -.0527 & -.0478 & -.0195 \\
\hline $\begin{array}{l}\text { Hispanic or } \\
\text { Latino (R3) }\end{array}$ & .015 & -.0105 & -.0033 & -.0551 & -.050 & -.0152 \\
\hline Asian (R4) & -.023 & -.0047 & -.0187 & -.009 & -.0089 & .0113 \\
\hline Other (R5) & -.008 & -.0087 & -.0205 & .0058 & .0089 & .0007 \\
\hline $\begin{array}{l}\text { Do not know } \\
\text { parent's } \\
\text { education } \\
\text { level (SPEL1) }\end{array}$ & -.035 & -.0365 & -.0282 & -.0767 & -.0585 & -.021 \\
\hline $\begin{array}{l}\text { Did not } \\
\text { complete high } \\
\text { school } \\
\text { (SPEL2) }\end{array}$ & -.0544 & -.0563 & -.0435 & -.1183 & -.0901 & -.0323 \\
\hline $\begin{array}{l}\text { High school } \\
\text { diploma or } \\
\text { equivalent } \\
\text { (SPEL3) }\end{array}$ & -.1453 & -.1504 & -.1164 & -.3162 & -.241 & -.0864 \\
\hline
\end{tabular}




\begin{tabular}{|l|c|c|c|c|c|c|}
\hline $\begin{array}{l}\text { Vocational or } \\
\text { technical } \\
\text { training } \\
\text { (SPEL4) }\end{array}$ & -.0531 & -.055 & -.0425 & -.1155 & -.088 & -.0316 \\
\hline $\begin{array}{l}\text { Less than two } \\
\text { years of } \\
\text { college } \\
\text { (SPEL5) }\end{array}$ & 1 & -.0766 & -.0593 & -.161 & -.1227 & -.044 \\
\hline $\begin{array}{l}\text { Associate's } \\
\text { degree } \\
\text { (SPEL6) }\end{array}$ & -.0766 & 1 & -.0613 & -.1666 & -.127 & -.0455 \\
\hline $\begin{array}{l}\text { 2 or more } \\
\text { years of } \\
\text { college but no } \\
\text { degree } \\
\text { (SPEL7) }\end{array}$ & -.0593 & -.0613 & 1 & -.1289 & -.0983 & -.0352 \\
\hline $\begin{array}{l}\text { Bachelor's } \\
\text { degree } \\
\text { (SPEL8) }\end{array}$ &.- .161 & -.1666 & -.1289 & & & \\
\hline $\begin{array}{l}\text { Master's } \\
\text { degree or } \\
\text { equivalent } \\
\text { (SPEL9) }\end{array}$ & -.1227 & -.127 & -.0983 & -.2669 & & \\
\hline $\begin{array}{l}\text { First- } \\
\text { professional } \\
\text { degree } \\
\text { (SPEL10) }\end{array}$ & -.044 & -.0455 & -.0352 & -.0957 & -.0729 & -.0969 \\
\hline $\begin{array}{l}\text { Grade point } \\
\text { average } \\
\text { (SGPA) }\end{array}$ & -.0182 & -.0078 & -.006 & .0047 & .0371 & \\
\hline $\begin{array}{l}\text { Attend } \\
\text { institution in } \\
\text { state of legal } \\
\text { residence=Ye } \\
\text { s (LOC1) }\end{array}$ & .030 & .016 & .0234 & -.0301 & -.0491 & -.0193 \\
\hline $\begin{array}{l}\text { Attend } \\
\text { institution in } \\
\text { state of legal } \\
\text { residence=No } \\
\text { (LOC2) }\end{array}$ & -.0232 & -.0187 & -.0169 & .0281 & .0554 & \\
\hline $\begin{array}{l}\text { Veteran } \\
\text { status=Not a } \\
\text { veteran } \\
\text { (SVA) }\end{array}$ & -.0041 & -.0091 & .0013 & .0341 & .0295 & \\
\hline
\end{tabular}




\begin{tabular}{|c|c|c|c|c|c|c|}
\hline $\begin{array}{l}\text { Undeclared or } \\
\text { not in a } \\
\text { degree } \\
\text { program } \\
\text { (PROGN1) }\end{array}$ & -.0092 & -.0185 & .0028 & .0027 & -.0069 & .016 \\
\hline $\begin{array}{l}\text { Humanities } \\
\text { (PROGN2) }\end{array}$ & -.0074 & -.006 & -.0021 & -.0071 & .0213 & .0102 \\
\hline $\begin{array}{l}\text { Social/ } \\
\text { behavioral } \\
\text { sciences } \\
\text { (PROGN3) }\end{array}$ & .0021 & -.0049 & .0182 & -.0083 & .0086 & .0048 \\
\hline $\begin{array}{l}\text { Life sciences } \\
\text { (PROGN4) }\end{array}$ & -.011 & -.013 & -.001 & .017 & .011 & .012 \\
\hline $\begin{array}{l}\text { Physical } \\
\text { sciences } \\
\text { (PROGN5) }\end{array}$ & .002 & .003 & -.009 & -.005 & .015 & .003 \\
\hline $\begin{array}{l}\text { Math } \\
\text { (PROGN6) }\end{array}$ & -.006 & .026 & -.016 & -.001 & -.007 & -.001 \\
\hline $\begin{array}{l}\text { Computer/ } \\
\text { information } \\
\text { science } \\
\text { (PROGN7) } \\
\end{array}$ & -.018 & -.006 & -.011 & .013 & -.001 & .013 \\
\hline $\begin{array}{l}\text { Engineering } \\
\text { (PROGN8) }\end{array}$ & -.006 & -.003 & -.007 & .020 & .022 & .013 \\
\hline $\begin{array}{l}\text { Education } \\
\text { (PROGN9) }\end{array}$ & .041 & -.007 & .005 & -.014 & -.016 & -.011 \\
\hline $\begin{array}{l}\text { Business/ } \\
\text { management } \\
(\text { PROGN10) }\end{array}$ & -.005 & .016 & -.005 & -.001 & -.003 & -.033 \\
\hline $\begin{array}{l}\text { Health } \\
(\text { PROGN11) }\end{array}$ & .014 & .013 & .006 & -.015 & -.026 & -.007 \\
\hline $\begin{array}{l}\text { Vocational/ } \\
\text { technical } \\
\text { (PROGN12) }\end{array}$ & .002 & -.007 & -.011 & .006 & .005 & -.008 \\
\hline
\end{tabular}

Table 62: Equation 5d correlations (continued)

\begin{tabular}{|l|l|l|l|l|l|l|}
\hline & $\begin{array}{l}\text { Grade } \\
\text { point } \\
\text { average }\end{array}$ & $\begin{array}{l}\text { Attend } \\
\text { institution } \\
\text { in state of } \\
\text { legal } \\
\text { residence } \\
\text { =Yes }\end{array}$ & $\begin{array}{l}\text { Attend } \\
\text { institution } \\
\text { in state of } \\
\text { legal } \\
\text { residence } \\
\text { =No }\end{array}$ & $\begin{array}{l}\text { Veteran } \\
\text { status=Not } \\
\text { a veteran }\end{array}$ & $\begin{array}{l}\text { Undeclared } \\
\text { or not in a } \\
\text { degree } \\
\text { program }\end{array}$ & Humanities \\
& & & \\
\hline
\end{tabular}




\begin{tabular}{|c|c|c|c|c|c|c|}
\hline $\begin{array}{l}\text { Institutional } \\
\text { need-based } \\
\text { grants } \\
\text { (IFPBN) }\end{array}$ & .035 & -.036 & .033 & .021 & -.016 & .011 \\
\hline Age (SA) & .133 & .095 & -.097 & -.202 & .001 & .008 \\
\hline $\begin{array}{l}\text { Adjusted } \\
\text { Gross Income } \\
\text { (SAGI) }\end{array}$ & .048 & -.076 & .099 & .056 & .010 & -.008 \\
\hline White (R1) & .121 & .028 & .025 & .011 & -.002 & .017 \\
\hline $\begin{array}{l}\text { Black or } \\
\text { African } \\
\text { American } \\
\text { (R2) }\end{array}$ & -.132 & -.039 & .033 & -.021 & -.034 & -.038 \\
\hline $\begin{array}{l}\text { Hispanic or } \\
\text { Latino (R3) }\end{array}$ & -.054 & .043 & -.048 & .007 & .010 & .016 \\
\hline Asian (R4) & .016 & -.064 & -.020 & .012 & .013 & -.026 \\
\hline Other (R5) & -.009 & .014 & -.021 & -.021 & .028 & .008 \\
\hline $\begin{array}{l}\text { Do not know } \\
\text { parent's } \\
\text { education } \\
\text { level (SPEL1) }\end{array}$ & -.027 & .010 & -.019 & -.038 & -.002 & .006 \\
\hline $\begin{array}{l}\text { Did not } \\
\text { complete high } \\
\text { school } \\
\text { (SPEL2) } \\
\end{array}$ & -.004 & .032 & -.035 & -.014 & .009 & -.011 \\
\hline $\begin{array}{l}\text { High school } \\
\text { diploma or } \\
\text { equivalent } \\
\text { (SPEL3) }\end{array}$ & -.045 & .040 & -.039 & -.039 & .006 & -.007 \\
\hline $\begin{array}{l}\text { Vocational or } \\
\text { technical } \\
\text { training } \\
\text { (SPEL4) }\end{array}$ & .025 & .002 & -.011 & -.012 & -.001 & $\begin{array}{l}.004 \\
\end{array}$ \\
\hline $\begin{array}{l}\text { Less than two } \\
\text { years of } \\
\text { college } \\
\text { (SPEL5) }\end{array}$ & -.018 & 0.030 & -.023 & -.004 & -.009 & -.007 \\
\hline $\begin{array}{l}\text { Associate's } \\
\text { degree } \\
\text { (SPEL6) }\end{array}$ & -.008 & .016 & -.019 & -.009 & -.019 & -.006 \\
\hline
\end{tabular}




\begin{tabular}{|c|c|c|c|c|c|c|}
\hline $\begin{array}{l}2 \text { or more } \\
\text { years of } \\
\text { college but no } \\
\text { degree } \\
\text { (SPEL } 7)\end{array}$ & -.006 & .023 & -.017 & .001 & .003 & -.002 \\
\hline $\begin{array}{l}\text { Bachelor's } \\
\text { degree } \\
\text { (SPEL8) } \\
\end{array}$ & .005 & -.030 & .028 & .034 & .003 & -.007 \\
\hline $\begin{array}{l}\text { Master's } \\
\text { degree or } \\
\text { equivalent } \\
\text { (SPEL9) }\end{array}$ & .037 & -.049 & .055 & .030 & -.007 & .021 \\
\hline $\begin{array}{l}\text { First- } \\
\text { professional } \\
\text { degree } \\
\text { (SPEL10) }\end{array}$ & .033 & -.019 & .017 & .002 & .016 & .010 \\
\hline $\begin{array}{l}\text { Grade point } \\
\text { average } \\
\text { (SGPA) }\end{array}$ & 1 & -.023 & .008 & -.027 & -.053 & .023 \\
\hline $\begin{array}{l}\text { Attend } \\
\text { institution in } \\
\text { state of legal } \\
\text { residence= } \\
\text { Yes (LOC1) }\end{array}$ & -.023 & 1 & -.906 & -.027 & .015 & -.008 \\
\hline $\begin{array}{l}\text { Attend } \\
\text { institution in } \\
\text { state of legal } \\
\text { residence=No } \\
\text { (LOC2) }\end{array}$ & .008 & -.906 & 1 & .021 & -.012 & .009 \\
\hline $\begin{array}{l}\text { Veteran } \\
\text { status=Not a } \\
\text { veteran } \\
(\text { SVA) }\end{array}$ & -.027 & -.027 & .021 & 1 & 0 & .003 \\
\hline $\begin{array}{l}\text { Undeclared or } \\
\text { not in a } \\
\text { degree } \\
\text { program } \\
\text { (PROGN1) }\end{array}$ & -.053 & .015 & -.012 & 0 & 1 & -.133 \\
\hline $\begin{array}{l}\text { Humanities } \\
\text { (PROGN2) }\end{array}$ & .023 & -.008 & .009 & .003 & -.133 & 1 \\
\hline $\begin{array}{l}\text { Social/ } \\
\text { behavioral } \\
\text { sciences } \\
\text { (PROGN3) }\end{array}$ & -.008 & .016 & -.011 & .018 & -.139 & -.130 \\
\hline
\end{tabular}




\begin{tabular}{|l|r|r|r|r|r|r|}
\hline $\begin{array}{l}\text { Life sciences } \\
\text { (PROGN4) }\end{array}$ & .006 & -.016 & .014 & .012 & -.104 & -.097 \\
\hline $\begin{array}{l}\text { Physical } \\
\text { sciences } \\
\text { (PROGN5) }\end{array}$ & .014 & -.001 & .002 & -.010 & -.042 & -.039 \\
\hline $\begin{array}{l}\text { Math } \\
\text { (PROGN6) }\end{array}$ & .002 & -.006 & .001 & .009 & -.034 & -.032 \\
\hline $\begin{array}{l}\text { Computer/ } \\
\text { information } \\
\text { science } \\
\text { (PROGN7) }\end{array}$ & -.024 & -.004 & -.006 & -.019 & -.078 & -.073 \\
\hline $\begin{array}{l}\text { Engineering } \\
\text { (PROGN8) }\end{array}$ & -.008 & -.048 & .041 & -.010 & -.097 & -.091 \\
\hline $\begin{array}{l}\text { Education } \\
\text { (PROGN9) }\end{array}$ & .066 & .041 & -.033 & .017 & -.124 & -.116 \\
\hline $\begin{array}{l}\text { Business/ } \\
\text { management } \\
\text { (PROGN10) }\end{array}$ & -.026 & -.006 & -.011 & -.002 & -.164 & -.153 \\
\hline $\begin{array}{l}\text { Health } \\
\text { (PROGN11) }\end{array}$ & .046 & .023 & -.014 & -.007 & -.107 & -.100 \\
\hline $\begin{array}{l}\text { Vocational/ } \\
\text { technical } \\
\text { (PROGN12) }\end{array}$ & -.004 & -.038 & .044 & -.008 & -.042 & -.039 \\
\hline
\end{tabular}

Table 62: Equation 5d correlations (continued)

\begin{tabular}{|l|r|r|r|r|r|r|}
\hline & $\begin{array}{l}\text { Social/ } \\
\text { behavioral } \\
\text { sciences }\end{array}$ & $\begin{array}{l}\text { Life } \\
\text { sciences }\end{array}$ & $\begin{array}{l}\text { Physical } \\
\text { sciences }\end{array}$ & Math & $\begin{array}{l}\text { Computer/ } \\
\text { information } \\
\text { science }\end{array}$ & Engineering \\
\hline $\begin{array}{l}\text { Institutional } \\
\text { need-based } \\
\text { grants } \\
\text { (IFPBN) }\end{array}$ & .021 & .032 & .013 & .014 & -.007 & .009 \\
\hline Age (SA) & -.017 & -.047 & -.004 & -.004 & .018 & -.041 \\
\hline $\begin{array}{l}\text { Adjusted } \\
\text { Gross Income } \\
\text { (SAGI) }\end{array}$ & -.011 & .002 & -.004 & -.001 & -.006 & .031 \\
\hline White (R1) & -.012 & -.004 & .003 & -.011 & -.025 & -.008 \\
\hline $\begin{array}{l}\text { Black or } \\
\text { African } \\
\text { American } \\
\text { (R2) }\end{array}$ & .011 & -.009 & -.009 & -.012 & .023 & .002 \\
\hline
\end{tabular}




\begin{tabular}{|c|c|c|c|c|c|c|}
\hline $\begin{array}{l}\text { Hispanic or } \\
\text { Latino (R3) }\end{array}$ & .009 & -.005 & -.008 & .015 & -.022 & -.013 \\
\hline Asian (R4) & .0018 & .0228 & .0057 & .0278 & .0469 & .0263 \\
\hline Other (R5) & -.009 & .005 & -.005 & -.011 & .001 & -.006 \\
\hline $\begin{array}{l}\text { Do not know } \\
\text { parent's } \\
\text { education } \\
\text { level (SPEL1) }\end{array}$ & -.003 & -.015 & .011 & -.002 & .010 & -.013 \\
\hline $\begin{array}{l}\text { Did not } \\
\text { complete high } \\
\text { school } \\
\text { (SPEL2) }\end{array}$ & -.003 & -.021 & -.015 & .012 & -.010 & -.011 \\
\hline $\begin{array}{l}\text { High school } \\
\text { diploma or } \\
\text { equivalent } \\
\text { (SPEL3) }\end{array}$ & -.009 & -.014 & -.006 & -.004 & -.001 & -.038 \\
\hline $\begin{array}{l}\text { Vocational or } \\
\text { technical } \\
\text { training } \\
\text { (SPEL4) } \\
\end{array}$ & -.014 & .007 & -.009 & .005 & .013 & -.002 \\
\hline $\begin{array}{l}\text { Less than two } \\
\text { years of } \\
\text { college } \\
\text { (SPEL5) } \\
\end{array}$ & .002 & -.011 & .002 & -.006 & -.018 & -.006 \\
\hline $\begin{array}{l}\text { Associate's } \\
\text { degree } \\
\text { (SPEL6) } \\
\end{array}$ & -.005 & -.013 & .003 & .026 & -.006 & -.003 \\
\hline $\begin{array}{l}2 \text { or more } \\
\text { years of } \\
\text { college but no } \\
\text { degree } \\
\text { (SPEL7) }\end{array}$ & .018 & -.001 & -.009 & -.016 & -.011 & -.007 \\
\hline $\begin{array}{l}\text { Bachelor's } \\
\text { degree } \\
\text { (SPEL8) } \\
\end{array}$ & -.008 & .017 & -.005 & -.001 & .013 & .020 \\
\hline $\begin{array}{l}\text { Master's } \\
\text { degree or } \\
\text { equivalent } \\
\text { (SPEL9) }\end{array}$ & .009 & .011 & .015 & -.007 & -.001 & .022 \\
\hline $\begin{array}{l}\text { First- } \\
\text { professional } \\
\text { degree } \\
\text { (SPEL10) } \\
\end{array}$ & .005 & .012 & .003 & -.001 & .013 & .013 \\
\hline
\end{tabular}




\begin{tabular}{|c|c|c|c|c|c|c|}
\hline $\begin{array}{l}\text { Grade point } \\
\text { average } \\
\text { (SGPA) }\end{array}$ & -.008 & .006 & .014 & .002 & -.024 & -.008 \\
\hline $\begin{array}{l}\text { Attend } \\
\text { institution in } \\
\text { state of legal } \\
\text { residence } \\
=\text { Yes (LOC1) }\end{array}$ & .016 & -.016 & -.001 & -.006 & -.004 & -.048 \\
\hline $\begin{array}{l}\text { Attend } \\
\text { institution in } \\
\text { state of legal } \\
\text { residence=No } \\
\text { (LOC2) }\end{array}$ & -.011 & .014 & .002 & .001 & -.006 & .041 \\
\hline $\begin{array}{l}\text { Veteran } \\
\text { status=Not a } \\
\text { veteran } \\
\text { (SVA) }\end{array}$ & .0176 & .0119 & -.0095 & .009 & -.0186 & -.0099 \\
\hline $\begin{array}{l}\text { Undeclared or } \\
\text { not in a } \\
\text { degree } \\
\text { program } \\
\text { (PROGN1) }\end{array}$ & -.139 & -.104 & -.042 & -.034 & -.078 & -.097 \\
\hline $\begin{array}{l}\text { Humanities } \\
\text { (PROGN2) }\end{array}$ & -.130 & -.097 & -.039 & -.032 & -.073 & -.091 \\
\hline $\begin{array}{l}\text { Social/ } \\
\text { behavioral } \\
\text { sciences } \\
\text { (PROGN3) } \\
\end{array}$ & 1 & -.102 & -.041 & -.033 & -.077 & -.095 \\
\hline $\begin{array}{l}\text { Life sciences } \\
\text { (PROGN4) }\end{array}$ & -.102 & 1 & -.031 & -.025 & -.058 & -.071 \\
\hline $\begin{array}{l}\text { Physical } \\
\text { sciences } \\
\text { (PROGN5) } \\
\end{array}$ & -.041 & -.031 & 1 & -.010 & -.023 & -.029 \\
\hline $\begin{array}{l}\text { Math } \\
(\text { PROGN6) }\end{array}$ & -.033 & -.025 & -.010 & 1 & -.019 & -.023 \\
\hline $\begin{array}{l}\text { Computer/ } \\
\text { information } \\
\text { science } \\
\text { (PROGN7) }\end{array}$ & -.077 & -.058 & -.023 & -.019 & 1 & -.054 \\
\hline $\begin{array}{l}\text { Engineering } \\
\text { (PROGN8) }\end{array}$ & -.095 & -.071 & -.029 & -.023 & -.054 & 1 \\
\hline $\begin{array}{l}\text { Education } \\
\text { (PROGN9) }\end{array}$ & -.121 & -.091 & -.036 & -.029 & -.068 & -.085 \\
\hline $\begin{array}{l}\text { Business/ } \\
\text { management }\end{array}$ & -.160 & -.120 & -.048 & -.039 & -.091 & -.112 \\
\hline
\end{tabular}




\begin{tabular}{|l|r|r|r|r|r|r|}
\hline (PROGN10) & & & & & & \\
\hline $\begin{array}{l}\text { Health } \\
\text { (PROGN11) }\end{array}$ & -.104 & -.078 & -.031 & -.025 & -.059 & -.073 \\
\hline $\begin{array}{l}\text { Vocationa1/ } \\
\text { technical } \\
\text { (PROGN12) }\end{array}$ & -.041 & -.031 & -.012 & -.010 & -.023 & -.029 \\
\hline
\end{tabular}

62: Equation $5 d$ correlations (continued)

\begin{tabular}{|c|c|c|c|c|}
\hline & Education & $\begin{array}{l}\text { Business/ } \\
\text { management }\end{array}$ & Health & $\begin{array}{l}\text { Vocational/ } \\
\text { technical }\end{array}$ \\
\hline $\begin{array}{l}\text { Institutional } \\
\text { need-based } \\
\text { grants } \\
\text { (IFPBN) } \\
\end{array}$ & -.023 & -.016 & -.001 & -.013 \\
\hline Age (SA) & .023 & .016 & .038 & .012 \\
\hline $\begin{array}{l}\text { Adjusted } \\
\text { Gross Income } \\
\text { (SAGI) }\end{array}$ & -.014 & .005 & -.019 & .001 \\
\hline White (R1) & .056 & -.033 & .010 & .022 \\
\hline $\begin{array}{l}\text { Black or } \\
\text { African } \\
\text { American } \\
\text { (R2) }\end{array}$ & -.023 & .040 & .002 & -.025 \\
\hline $\begin{array}{l}\text { Hispanic or } \\
\text { Latino (R3) }\end{array}$ & .001 & -.010 & -.006 & -.004 \\
\hline Asian (R4) & -.060 & .031 & -.011 & -.003 \\
\hline Other (R5) & -.020 & .008 & -.001 & -.003 \\
\hline $\begin{array}{l}\text { Do not know } \\
\text { parent's } \\
\text { education } \\
\text { level (SPEL1) }\end{array}$ & .001 & .011 & .003 & -.002 \\
\hline $\begin{array}{l}\text { Did not } \\
\text { complete high } \\
\text { school } \\
\text { (SPEL2) } \\
\end{array}$ & .007 & .013 & .023 & .001 \\
\hline $\begin{array}{l}\text { High school } \\
\text { diploma or } \\
\text { equivalent } \\
\text { (SPEL3) }\end{array}$ & .025 & .010 & .008 & .005 \\
\hline
\end{tabular}




\begin{tabular}{|c|c|c|c|c|}
\hline $\begin{array}{l}\text { Vocational or } \\
\text { technical } \\
\text { training } \\
\text { (SPEL4) }\end{array}$ & -.008 & -.001 & .021 & -.004 \\
\hline $\begin{array}{l}\text { Less than two } \\
\text { years of } \\
\text { college } \\
\text { (SPEL5) }\end{array}$ & .041 & -.005 & .014 & .002 \\
\hline $\begin{array}{l}\text { Associate's } \\
\text { degree } \\
\text { (SPEL6) } \\
\end{array}$ & -.007 & .016 & .013 & -.007 \\
\hline $\begin{array}{l}2 \text { or more } \\
\text { years of } \\
\text { college but no } \\
\text { degree } \\
\text { (SPEL7) }\end{array}$ & .005 & -.005 & .006 & -.011 \\
\hline $\begin{array}{l}\text { Bachelor's } \\
\text { degree } \\
\text { (SPEL8) }\end{array}$ & -.014 & -.001 & -.015 & .006 \\
\hline $\begin{array}{l}\text { Master's } \\
\text { degree or } \\
\text { equivalent } \\
\text { (SPEL9) }\end{array}$ & -.016 & -.003 & -.026 & .005 \\
\hline $\begin{array}{l}\text { First- } \\
\text { professional } \\
\text { degree } \\
\text { (SPEL10) }\end{array}$ & -.011 & -.033 & -.007 & -.008 \\
\hline $\begin{array}{l}\text { Grade point } \\
\text { average } \\
\text { (SGPA) }\end{array}$ & .066 & -.026 & .046 & -.004 \\
\hline $\begin{array}{l}\text { Attend } \\
\text { institution in } \\
\text { state of legal } \\
\text { residence } \\
=\text { Yes (LOC1) }\end{array}$ & .041 & -.006 & .023 & -.038 \\
\hline $\begin{array}{l}\text { Attend } \\
\text { institution in } \\
\text { state of legal } \\
\text { residence=No } \\
\text { (LOC2) }\end{array}$ & -.033 & -.011 & -.014 & .044 \\
\hline $\begin{array}{l}\text { Veteran } \\
\text { status=Not a } \\
\text { veteran } \\
(\mathrm{SVA})\end{array}$ & .017 & -.002 & -.007 & -.008 \\
\hline
\end{tabular}




\begin{tabular}{|l|c|c|c|c|}
\hline $\begin{array}{l}\text { Undeclared or } \\
\text { not in a } \\
\text { degree } \\
\text { program } \\
\text { (PROGN1) }\end{array}$ & -.124 & -.164 & -.107 & -.042 \\
\hline $\begin{array}{l}\text { Humanities } \\
\text { (PROGN2) }\end{array}$ & -.116 & -.153 & -.100 & -.039 \\
\hline $\begin{array}{l}\text { Social/ } \\
\text { behavioral } \\
\text { sciences } \\
\text { (PROGN3) }\end{array}$ & -.121 & -.16 & -.104 & -.041 \\
\hline $\begin{array}{l}\text { Life sciences } \\
\text { (PROGN4) }\end{array}$ & -.091 & -.120 & -.078 & -.031 \\
\hline $\begin{array}{l}\text { Physical } \\
\text { sciences } \\
\text { (PROGN5) }\end{array}$ & -.036 & -.048 & -.031 & -.012 \\
\hline $\begin{array}{l}\text { Math } \\
\text { (PROGN6) }\end{array}$ & -.029 & -.039 & -.025 & -.010 \\
\hline $\begin{array}{l}\text { Computer/ } \\
\text { information } \\
\text { science } \\
\text { (PROGN7) }\end{array}$ & -.068 & -.091 & -.059 & -.023 \\
\hline $\begin{array}{l}\text { Engineering } \\
\text { (PROGN8) }\end{array}$ & -.085 & -.112 & -.073 & -.029 \\
\hline $\begin{array}{l}\text { Education } \\
\text { (PROGN9) }\end{array}$ & -.143 & -.143 & -.093 & -.036 \\
\hline $\begin{array}{l}\text { Business/ } \\
\text { management } \\
\text { (PROGN10) }\end{array}$ & & & & \\
\hline $\begin{array}{l}\text { Health } \\
\text { (PROGN11) }\end{array}$ & -.093 & & & \\
\hline $\begin{array}{l}\text { Vocational/ } \\
\text { technical } \\
\text { (PROGN12) }\end{array}$ & & & & \\
\hline
\end{tabular}

The results of this equation indicate that a significant relationship exists between the amount of institutional need-based financial grant aid paid per student by public institutions students' ages, the adjusted gross income of their parents or the students if they were independent and their statuses as Asians. Relationships were also noted between the dependent variable and the education levels of parents who did not complete high school. A relationship 
exists between the dependent variable and students' grade point averages, their statuses as veterans, as well as students who majored in life sciences and vocational/technical programs. These relationships are represented by the following econometric equation:

IFPBN $=-11.869 \mathrm{SA}-.001 \mathrm{SAGI}+177.107 \mathrm{SR} 4+169.581 \mathrm{SPEL} 2+0.854 \mathrm{SGPA}_{\mathrm{i}}+$ 70.952SVA + 128.025PROG4 -96.727PROG12 + 219.338

Research Question 5e: Is there a significant relationship between institutional needbased financial grant aid paid per student paid by private institutions, student characteristics, and academic programs? Research Question 5e relates to Hypothesis $\left(\mathrm{H}_{5 \mathrm{e}}\right)$, that there is no significant relationship between institutional need-based financial grant aid paid per student by private institutions, student characteristics, and academic programs. As described in Chapter 3, Equation 5e relates to Research Question 5e and Hypothesis 5e:

$$
\mathrm{IFPVN}_{\mathrm{i}}=\mathrm{SA}_{\mathrm{i}}+\mathrm{SAGI}_{\mathrm{i}}+\mathrm{SR}_{\mathrm{i}}+\mathrm{SG}_{\mathrm{i}}+\mathrm{SPEL}_{\mathrm{i}}+\mathrm{SGPA}_{\mathrm{i}}+\mathrm{SVA}_{\mathrm{i}}+\mathrm{LOC}_{\mathrm{i}}+\mathrm{PROGN}_{\mathrm{i}}
$$

The significance scores for this equation are displayed in Table 63. The NCES' DAS was used to perform a weighted least squares computation using NPSAS: 04 data.

Table 63: Equation 5e hypothesis testing results

\begin{tabular}{|l|r|r|r|r|r|}
\hline & Wald F & $\begin{array}{l}\text { Num. } \\
\text { DF }\end{array}$ & $\begin{array}{l}\text { Denom. } \\
\text { DF }\end{array}$ & Commonality & \multicolumn{2}{l|}{$\begin{array}{l}\text { Probability } \\
F\end{array}$} \\
\hline Overall Fit & 16.669 & 34 & 31 & & 0.001 \\
\hline Age (SA) & 177.29 & 1 & 64 & 0.029 & 0.001 \\
\hline $\begin{array}{l}\text { Adjusted Gross Income } \\
\text { (AGI) }\end{array}$ & 62.682 & 1 & 64 & 0.007 & 0.001 \\
\hline Race (SR) & 5.192 & 5 & 60 & 0.007 & 0.001 \\
\hline Gender (SG) & 0.010 & 1 & 64 & 0.000 & 0.921 \\
\hline $\begin{array}{l}\text { Parent's highest } \\
\text { education level (SPEL) }\end{array}$ & 1.363 & 10 & 55 & 0.002 & 0.222 \\
\hline $\begin{array}{l}\text { Grade point average } \\
\text { (SGPA) }\end{array}$ & 9.908 & 1 & 64 & 0.002 & 0.002 \\
\hline $\begin{array}{l}\text { Attend institution in } \\
\text { state of legal residence } \\
\text { (LOC) }\end{array}$ & 21.151 & 2 & 63 & 0.014 & 0.001 \\
\hline
\end{tabular}




\begin{tabular}{|l|r|r|r|r|r|}
\hline Veteran status (SVA) & 1.842 & 1 & 64 & 0.000 & 0.180 \\
\hline Program (PROGN) & 5.887 & 12 & 53 & 0.014 & 0.001 \\
\hline
\end{tabular}

The variables, Gender (SG), Parent's highest education level (SPEL), and Veteran status (VA) were not significant. Because they were not significant, a second computation was completed without these variables. The significance scores for this equation are displayed in Table 64 and the regression coefficients are displayed in Table 65. The coefficients for the variables Age, Adjusted gross income, Grade point average, Attend institution in state of legal residence-yes, Attend institution in state of legal residence-no, Undeclared or not in a degree program, Humanities, Social/behavioral Sciences, Life sciences, Math, and Engineering were significant. The coefficient of determination was .0933. From this statistic, we may conclude that 9.33 percent of the variance in institutional need-based financial grant aid per student paid by private institutions is explained by the independent variables in this equation.

\section{.001}

Table 64: Equation 5e hypothesis testing results

\begin{tabular}{|l|r|r|r|r|r|}
\hline & Wald F & Num. DF & $\begin{array}{l}\text { Denom. } \\
\text { DF }\end{array}$ & Commonality & $\begin{array}{l}\text { Probability } \\
F\end{array}$ \\
\hline Overall Fit & 30.238 & 22 & 43 & & .001 \\
\hline Age (SA) & 182.540 & 1 & 64 & .036 & .001 \\
\hline $\begin{array}{l}\text { Adjusted Gross } \\
\text { Income (AGI) }\end{array}$ & 63.249 & 1 & 64 & .008 & .001 \\
\hline Race (SR) & 5.119 & 5 & 60 & .006 & .001 \\
\hline $\begin{array}{l}\text { Grade point average } \\
\text { (SGPA) }\end{array}$ & 10.012 & 1 & 64 & .002 & .002 \\
\hline $\begin{array}{l}\text { Attend institution in } \\
\text { state of legal } \\
\text { residence (LOC) }\end{array}$ & 20.571 & 2 & 63 & .013 & .001 \\
\hline Program (PROGN) & 5.453 & 12 & 53 & & .014 \\
\hline
\end{tabular}


Table 65: Equation 5e estimated full sample regression coefficients

\begin{tabular}{|c|c|c|c|c|}
\hline & $\mathrm{B}$ & s.e. & $t$ & Probability $t$ \\
\hline Intercept & 2763.367 & 483.147 & 5.72 & .001 \\
\hline Age (SA) & -97.655 & 7.228 & -13.511 & .001 \\
\hline Adjusted Gross Income (SAGI) & -.007 & .001 & -7.953 & .001 \\
\hline \multicolumn{5}{|l|}{ Race } \\
\hline White (R1) & -665.993 & 408.85 & -1.629 & .108 \\
\hline Black or African American (R2) & -607.143 & 481.428 & -1.261 & .212 \\
\hline Hispanic or Latino (R3) & -150.458 & 446.377 & -.337 & .737 \\
\hline Asian (R4) & 851.306 & 501.652 & 1.697 & .095 \\
\hline Other (R5) & -407.248 & 511.325 & -.796 & .429 \\
\hline \multicolumn{5}{|l|}{ vs. More than one race } \\
\hline Grade point average (SGPA) & 2.770 & 0.875 & 3.164 & .002 \\
\hline \multicolumn{5}{|l|}{$\begin{array}{l}\text { Attend institution in state of legal } \\
\text { residence }\end{array}$} \\
\hline Yes (LOC1) & 960.929 & 319.527 & 3.007 & .004 \\
\hline No (LOC2) & 1963.457 & 344.62 & 5.697 & .000 \\
\hline \multicolumn{5}{|l|}{ vs. Foreign or international student } \\
\hline \multicolumn{5}{|l|}{ Program } \\
\hline $\begin{array}{l}\text { Undeclared or not in a degree program } \\
\text { (PROGN1) }\end{array}$ & 749.780 & 224.698 & 3.337 & .001 \\
\hline Humanities (PROGN2) & 639.787 & 250.459 & 2.554 & .013 \\
\hline Social/behavioral sciences (PROGN3) & 1174.171 & 241.895 & 4.854 & .000 \\
\hline Life sciences (PROGN4) & 677.087 & 294.157 & 2.302 & .025 \\
\hline Physical sciences (PROGN5) & 269.071 & 661.909 & 0.407 & .686 \\
\hline Math (PROGN6) & 2214.238 & 953.361 & 2.323 & .023 \\
\hline $\begin{array}{l}\text { Computer/information science } \\
\text { (PROGN7) }\end{array}$ & -100.106 & 188.876 & -0.53 & .598 \\
\hline Engineering (PROGN8) & 1106.578 & 443.142 & 2.497 & .015 \\
\hline Education (PROGN9) & -64.123 & 209.344 & -0.306 & .760 \\
\hline Business/management (PROGN10) & -123.995 & 158.809 & -0.781 & .438 \\
\hline Health (PROGN11) & 367.146 & 234.994 & 1.562 & .123 \\
\hline Vocational/technical (PROGN12 & 28.130 & 330.618 & 0.085 & .932 \\
\hline vs. Other technical/professional & & & & \\
\hline
\end{tabular}

The correlations for this equation are displayed in Table 66. 
Table 66: Equation 5e correlations

\begin{tabular}{|c|c|c|c|c|c|c|}
\hline & $\begin{array}{l}\text { Institution } \\
\text { al need- } \\
\text { based } \\
\text { grants }\end{array}$ & $\begin{array}{l}\text { Age as } \\
\text { of } \\
12 / 31 / 03\end{array}$ & $\begin{array}{l}\text { Adjusted } \\
\text { Gross } \\
\text { Income } \\
\text { (AGI) }\end{array}$ & White & $\begin{array}{l}\text { Black or } \\
\text { African } \\
\text { American }\end{array}$ & $\begin{array}{l}\text { Hispanic } \\
\text { or } \\
\text { Latino }\end{array}$ \\
\hline $\begin{array}{l}\text { Institutional } \\
\text { need-based } \\
\text { grants } \\
\text { (IFPVN) }\end{array}$ & 1 & -.229 & -.026 & -.025 & -.042 & .021 \\
\hline Age (SA) & -.229 & 1 & -.177 & -.082 & .128 & .022 \\
\hline $\begin{array}{l}\text { Adjusted } \\
\text { Gross Income } \\
\text { (SAGI) }\end{array}$ & -.026 & -.177 & 1 & .190 & -.179 & -.078 \\
\hline White (R1) & -.025 & -.082 & .190 & 1 & -.603 & -.464 \\
\hline $\begin{array}{l}\text { Black or } \\
\text { African } \\
\text { American } \\
\text { (R2) }\end{array}$ & -.042 & .128 & -.179 & -.603 & 1 & -.121 \\
\hline $\begin{array}{l}\text { Hispanic or } \\
\text { Latino (R3) }\end{array}$ & .021 & .022 & -.078 & -.464 & -.121 & 1 \\
\hline Asian (R4) & .084 & -.069 & -.013 & -.327 & -.085 & -.066 \\
\hline Other (R5) & .002 & .016 & -.016 & -.206 & -.054 & -.041 \\
\hline $\begin{array}{l}\text { Grade point } \\
\text { average } \\
\text { (SGPA) }\end{array}$ & .001 & .158 & .100 & .160 & -.160 & -.062 \\
\hline $\begin{array}{l}\text { Attend } \\
\text { institution in } \\
\text { state of legal } \\
\text { residence } \\
=\text { Yes (LOC1) }\end{array}$ & -.138 & .218 & -.175 & -.057 & .054 & .070 \\
\hline $\begin{array}{l}\text { Attend } \\
\text { institution in } \\
\text { state of legal } \\
\text { residence=No } \\
\text { (LOC2) }\end{array}$ & .147 & -.208 & .195 & .091 & -.057 & -.068 \\
\hline $\begin{array}{l}\text { Undeclared or } \\
\text { not in a } \\
\text { degree } \\
\text { program } \\
\text { (PROGN1) }\end{array}$ & .041 & -.021 & .029 & .008 & -.042 & .017 \\
\hline $\begin{array}{l}\text { Humanities } \\
\text { (PROGN2) }\end{array}$ & .037 & -.064 & .017 & .045 & -.044 & -.001 \\
\hline
\end{tabular}




\begin{tabular}{|l|r|r|r|r|r|r|}
\hline $\begin{array}{l}\text { Social/ } \\
\text { behavioral } \\
\text { sciences } \\
\text { (PROGN3) }\end{array}$ & .090 & -.080 & .034 & .011 & -.032 & .003 \\
\hline $\begin{array}{l}\text { Life sciences } \\
\text { (PROGN4) }\end{array}$ & .036 & -.101 & .046 & -.006 & -.020 & .007 \\
\hline $\begin{array}{l}\text { Physical } \\
\text { sciences } \\
\text { (PROGN5) }\end{array}$ & .003 & -.040 & .018 & .008 & -.007 & -.024 \\
\hline $\begin{array}{l}\text { Math } \\
\text { (PROGN6) }\end{array}$ & .043 & -.034 & -.009 & .010 & -.025 & -.002 \\
\hline $\begin{array}{l}\text { Computer/ } \\
\text { information } \\
\text { science } \\
\text { (PROGN7) }\end{array}$ & -.044 & .069 & -.025 & -.034 & .042 & -.010 \\
\hline $\begin{array}{l}\text { Engineering } \\
\text { (PROGN8) }\end{array}$ & .041 & -.044 & .033 & .003 & -.019 & -.016 \\
\hline $\begin{array}{l}\text { Education } \\
\text { (PROGN9) }\end{array}$ & -.035 & -.014 & .007 & .059 & -.044 & .008 \\
\hline $\begin{array}{l}\text { Business/ } \\
\text { management } \\
\text { (PROGN10) }\end{array}$ & -.098 & .132 & -.044 & -.050 & .075 & .008 \\
\hline $\begin{array}{l}\text { Health } \\
\text { (PROGN11) }\end{array}$ & -.014 & .052 & -.055 & .018 & -.009 & -.021 \\
\hline $\begin{array}{l}\text { Vocational/ } \\
\text { technical } \\
\text { (PROGN12) }\end{array}$ & -.014 & .034 & -.006 & .012 & .003 & -.012 \\
\hline
\end{tabular}

Table 66: Equation 5e correlations (continued)

\begin{tabular}{|l|r|r|r|r|l|l|}
\hline & Asian & Other & $\begin{array}{l}\text { Grade } \\
\text { point } \\
\text { average }\end{array}$ & $\begin{array}{l}\text { Attend } \\
\text { institutio } \\
\text { n in state } \\
\text { of legal } \\
\text { residence } \\
\text { =Yes }\end{array}$ & $\begin{array}{l}\text { Attend } \\
\text { institution } \\
\text { in state of } \\
\text { legal } \\
\text { residence } \\
\text { =No }\end{array}$ & $\begin{array}{l}\text { Undeclared } \\
\text { or not in a } \\
\text { degree } \\
\text { program }\end{array}$ \\
\hline $\begin{array}{l}\text { Institutional } \\
\text { need-based } \\
\text { grants } \\
\text { (IFPVN) }\end{array}$ & .084 & .002 & .001 & -.138 & .147 & .041 \\
\hline $\begin{array}{l}\text { Age (SA) } \\
\text { Adjusted } \\
\text { Gross Income } \\
\text { (SAGI) }\end{array}$ & -.069 & .016 & .158 & .218 & -.208 & .021 \\
\hline
\end{tabular}




\begin{tabular}{|c|c|c|c|c|c|c|}
\hline White (R1) & -.327 & -.206 & .160 & -.057 & .091 & .008 \\
\hline $\begin{array}{l}\text { Black or } \\
\text { African } \\
\text { American } \\
\text { (R2) }\end{array}$ & -.085 & -.054 & -.160 & .054 & -.057 & -.042 \\
\hline $\begin{array}{l}\text { Hispanic or } \\
\text { Latino (R3) }\end{array}$ & -.066 & -.041 & -.062 & .070 & -.068 & .017 \\
\hline Asian (R4) & 1 & -.029 & .010 & -.055 & -.011 & .030 \\
\hline Other (R5) & -.029 & 1 & -.019 & -.014 & .003 & -.021 \\
\hline $\begin{array}{l}\text { Grade point } \\
\text { average } \\
\text { (SGPA) }\end{array}$ & .010 & -.019 & 1 & .003 & -.002 & -.019 \\
\hline $\begin{array}{l}\text { Attend } \\
\text { institution in } \\
\text { state of legal } \\
\text { residence } \\
=\text { Yes (LOC1) }\end{array}$ & -.055 & -.014 & .003 & 1 & -.947 & -.058 \\
\hline $\begin{array}{l}\text { Attend } \\
\text { institution in } \\
\text { state of legal } \\
\text { residence=No } \\
\text { (LOC2) }\end{array}$ & -.011 & .003 & -.002 & -.947 & 1 & .053 \\
\hline $\begin{array}{l}\text { Undeclared or } \\
\text { not in a } \\
\text { degree } \\
\text { program } \\
\text { (PROGN1) }\end{array}$ & .030 & -.021 & -.019 & -.058 & .053 & 1 \\
\hline $\begin{array}{l}\text { Humanities } \\
\text { (PROGN2) }\end{array}$ & -.035 & .019 & -.001 & -.037 & .050 & -.146 \\
\hline $\begin{array}{l}\text { Social/ } \\
\text { behavioral } \\
\text { sciences } \\
\text { (PROGN3) }\end{array}$ & .021 & .004 & .021 & -.034 & .038 & -.147 \\
\hline $\begin{array}{l}\text { Life sciences } \\
\text { (PROGN4) }\end{array}$ & .014 & .039 & -.001 & -.020 & .022 & -.093 \\
\hline $\begin{array}{l}\text { Physical } \\
\text { sciences } \\
\text { (PROGN5) } \\
\end{array}$ & -.006 & .042 & .014 & -.001 & -.001 & -.037 \\
\hline $\begin{array}{l}\text { Math } \\
\text { (PROGN6) }\end{array}$ & .012 & -.001 & .036 & .001 & -.004 & -.030 \\
\hline $\begin{array}{l}\text { Computer/ } \\
\text { information } \\
\text { science } \\
\text { (PROGN7) }\end{array}$ & .017 & -.003 & .018 & .029 & -.046 & -.087 \\
\hline
\end{tabular}




\begin{tabular}{|l|r|r|r|r|r|r|}
\hline $\begin{array}{l}\text { Engineering } \\
\text { (PROGN8) }\end{array}$ & .037 & -.004 & -0.030 & -.023 & .013 & -.079 \\
\hline $\begin{array}{l}\text { Education } \\
\text { (PROGN9) }\end{array}$ & -.052 & -.006 & .036 & .054 & -.043 & -.106 \\
\hline $\begin{array}{l}\text { Business/ } \\
\text { management } \\
\text { (PROGN10) }\end{array}$ & .005 & -.010 & -.018 & .048 & -.056 & -.205 \\
\hline $\begin{array}{l}\text { Health } \\
\text { (PROGN11) }\end{array}$ & .003 & -.016 & .018 & .056 & -.057 & -.106 \\
\hline $\begin{array}{l}\text { Vocational/ } \\
\text { technical } \\
\text { (PROGN12) }\end{array}$ & -.012 & -.010 & -.001 & -.025 & .025 & -.040 \\
\hline
\end{tabular}

Table 66: Equation 5e correlations (continued)

\begin{tabular}{|c|c|c|c|c|c|c|}
\hline & Humanities & $\begin{array}{l}\text { Social/ } \\
\text { behavioral } \\
\text { sciences }\end{array}$ & $\begin{array}{l}\text { Life } \\
\text { sciences }\end{array}$ & $\begin{array}{l}\text { Physical } \\
\text { sciences }\end{array}$ & Math & $\begin{array}{l}\text { Computer/ } \\
\text { information } \\
\text { science }\end{array}$ \\
\hline $\begin{array}{l}\text { Institutional } \\
\text { need-based } \\
\text { grants } \\
\text { (IFPVN) }\end{array}$ & .037 & .090 & .036 & .003 & .043 & -.044 \\
\hline Age (SA) & -.064 & -.080 & -.101 & -.040 & -.034 & .069 \\
\hline $\begin{array}{l}\text { Adjusted } \\
\text { Gross Income } \\
\text { (SAGI) }\end{array}$ & .017 & .034 & .046 & .018 & $\begin{array}{l}.009 \\
\end{array}$ & -.025 \\
\hline White (R1) & .045 & .011 & -.006 & .008 & .010 & -.034 \\
\hline $\begin{array}{l}\text { Black or } \\
\text { African } \\
\text { American } \\
\text { (R2) }\end{array}$ & -.044 & -.032 & -.020 & -.007 & -.025 & .042 \\
\hline $\begin{array}{l}\text { Hispanic or } \\
\text { Latino (R3) }\end{array}$ & -.001 & .003 & .007 & -.024 & -.002 & -.010 \\
\hline Asian (R4) & -.0345 & .0205 & .0144 & -.0064 & .0116 & .0167 \\
\hline Other (R5) & .019 & .004 & .039 & .042 & -.001 & -.003 \\
\hline $\begin{array}{l}\text { Grade point } \\
\text { average } \\
\text { (SGPA) }\end{array}$ & -.001 & .021 & -.001 & .014 & .036 & .018 \\
\hline
\end{tabular}




\begin{tabular}{|c|c|c|c|c|c|c|}
\hline $\begin{array}{l}\text { Attend } \\
\text { institution in } \\
\text { state of legal } \\
\text { residence } \\
=\text { Yes (LOC1) }\end{array}$ & -.037 & -.034 & -.020 & -.001 & .001 & .029 \\
\hline $\begin{array}{l}\text { Attend } \\
\text { institution in } \\
\text { state of legal } \\
\text { residence=No } \\
\text { (LOC2) }\end{array}$ & .050 & .038 & .022 & -.001 & -.004 & -.046 \\
\hline $\begin{array}{l}\text { Undeclared or } \\
\text { not in a } \\
\text { degree } \\
\text { program } \\
\text { (PROGN1) }\end{array}$ & -.146 & -.147 & -.093 & -.037 & -.030 & -.087 \\
\hline $\begin{array}{l}\text { Humanities } \\
\text { (PROGN2) }\end{array}$ & 1 & -.140 & -.089 & -.035 & -.029 & -.083 \\
\hline $\begin{array}{l}\text { Social/ } \\
\text { behavioral } \\
\text { sciences } \\
\text { (PROGN3) }\end{array}$ & -.140 & 1 & -.089 & -.035 & -.029 & -.083 \\
\hline $\begin{array}{l}\text { Life sciences } \\
\text { (PROGN4) }\end{array}$ & -.089 & -.089 & 1 & -.022 & -.018 & -.052 \\
\hline $\begin{array}{l}\text { Physical } \\
\text { sciences } \\
\text { (PROGN5) }\end{array}$ & -.035 & -.035 & -.022 & 1 & -.007 & -.021 \\
\hline $\begin{array}{l}\text { Math } \\
\text { (PROGN6) }\end{array}$ & -.029 & -.029 & -.018 & -.007 & 1 & -.017 \\
\hline $\begin{array}{l}\text { Computer/ } \\
\text { information } \\
\text { science } \\
\text { (PROGN7) }\end{array}$ & -.083 & -.083 & -.052 & -.021 & -.017 & 1 \\
\hline $\begin{array}{l}\text { Engineering } \\
\text { (PROGN8) }\end{array}$ & -.075 & -.075 & -.048 & -.019 & -.016 & -.045 \\
\hline $\begin{array}{l}\text { Education } \\
\text { (PROGN9) }\end{array}$ & -.101 & -.101 & -.064 & -.025 & -.021 & -.060 \\
\hline $\begin{array}{l}\text { Business/ } \\
\text { management } \\
\text { (PROGN10) }\end{array}$ & -.197 & -.197 & -.124 & -.049 & -.041 & -.116 \\
\hline $\begin{array}{l}\text { Health } \\
\text { (PROGN11) }\end{array}$ & -.102 & -.102 & -.065 & -.026 & -.021 & -.060 \\
\hline $\begin{array}{l}\text { Vocational/ } \\
\text { technical } \\
\text { (PROGN12) }\end{array}$ & -.039 & -.039 & -.025 & -.010 & -.008 & -.023 \\
\hline
\end{tabular}


Table 66: Equation 5e correlations (continued)

\begin{tabular}{|c|c|c|c|c|c|}
\hline & Engineering & Education & $\begin{array}{l}\text { Business/ } \\
\text { management }\end{array}$ & Health & $\begin{array}{l}\text { Vocational/ } \\
\text { technical }\end{array}$ \\
\hline $\begin{array}{l}\text { Institutional } \\
\text { need-based } \\
\text { grants } \\
\text { (IFPVN) }\end{array}$ & .041 & -.035 & -.098 & -.014 & -.014 \\
\hline Age (SA) & -.044 & -.014 & .132 & .052 & .034 \\
\hline $\begin{array}{l}\text { Adjusted } \\
\text { Gross Income } \\
\text { (SAGI) }\end{array}$ & .033 & .007 & -.044 & -.055 & -.006 \\
\hline White (R1) & .003 & .059 & -.050 & .018 & .012 \\
\hline $\begin{array}{l}\text { Black or } \\
\text { African } \\
\text { American } \\
\text { (R2) }\end{array}$ & -.019 & -.044 & .075 & -.009 & .003 \\
\hline $\begin{array}{l}\text { Hispanic or } \\
\text { Latino (R3) }\end{array}$ & -.016 & .008 & .008 & -.021 & -.012 \\
\hline Asian (R4) & .037 & -.052 & .005 & .003 & -.012 \\
\hline Other (R5) & -.004 & -.006 & -.010 & -.016 & -.010 \\
\hline $\begin{array}{l}\text { Grade point } \\
\text { average } \\
\text { (SGPA) }\end{array}$ & -.030 & .036 & $\begin{array}{l}-.018 \\
\end{array}$ & .018 & -.001 \\
\hline $\begin{array}{l}\text { Attend } \\
\text { institution in } \\
\text { state of legal } \\
\text { residence } \\
=\text { Yes (LOC1) }\end{array}$ & -.023 & .054 & .048 & .056 & -.025 \\
\hline $\begin{array}{l}\text { Attend } \\
\text { institution in } \\
\text { state of legal } \\
\text { residence=No } \\
\text { (LOC2) }\end{array}$ & .013 & $\begin{array}{l}-.043 \\
\end{array}$ & -.056 & $\begin{array}{l}-.057 \\
\end{array}$ & .025 \\
\hline $\begin{array}{l}\text { Undeclared or } \\
\text { not in a } \\
\text { degree } \\
\text { program } \\
\text { (PROGN1) }\end{array}$ & -.079 & -.106 & -.205 & -.106 & -.040 \\
\hline
\end{tabular}




\begin{tabular}{|c|c|c|c|c|c|}
\hline $\begin{array}{l}\text { Humanities } \\
\text { (PROGN2) }\end{array}$ & -.075 & -.101 & -.197 & -.102 & -.039 \\
\hline $\begin{array}{l}\text { Social/ } \\
\text { behavioral } \\
\text { sciences } \\
\text { (PROGN3) }\end{array}$ & -.075 & -.101 & -.197 & -.102 & -.039 \\
\hline $\begin{array}{l}\text { Life sciences } \\
\text { (PROGN4) }\end{array}$ & -.048 & -.064 & -.124 & -.065 & -.025 \\
\hline $\begin{array}{l}\text { Physical } \\
\text { sciences } \\
\text { (PROGN5) } \\
\end{array}$ & -.019 & -.025 & -.049 & -.026 & -.010 \\
\hline $\begin{array}{l}\text { Math } \\
\text { (PROGN6) }\end{array}$ & -.016 & -.021 & -.041 & -.021 & -.008 \\
\hline $\begin{array}{l}\text { Computer/ } \\
\text { information } \\
\text { science } \\
\text { (PROGN7) }\end{array}$ & -.045 & -.060 & -.116 & -.060 & -.023 \\
\hline $\begin{array}{l}\text { Engineering } \\
\text { (PROGN8) }\end{array}$ & 1 & -.054 & -.106 & -.055 & -.021 \\
\hline $\begin{array}{l}\text { Education } \\
\text { (PROGN9) }\end{array}$ & -.054 & 1 & -.142 & -.074 & -.028 \\
\hline $\begin{array}{l}\text { Business/ } \\
\text { management } \\
\text { (PROGN10) }\end{array}$ & -.106 & -.142 & 1 & -.143 & -.054 \\
\hline $\begin{array}{l}\text { Health } \\
\text { (PROGN11) }\end{array}$ & -.055 & -.074 & -.143 & 1 & -.028 \\
\hline $\begin{array}{l}\text { Vocational/ } \\
\text { technical } \\
\text { (PROGN12) }\end{array}$ & -.021 & -.028 & -.054 & -.028 & 1 \\
\hline
\end{tabular}

The results of this analysis identified significant relationships between the amount of institutional need-based financial grant aid paid per student by public institutions and students' ages, adjusted gross incomes, grade point averages, their statuses as residents of the states in which the institutions are located; their statuses as non-residents of the states in which the institutions are located; and their statuses as majors in humanities, social/behavioral sciences, life sciences, physical sciences, computer/information science and engineering. These relationships are represented by the following econometric equation: 


$$
\text { IFPVN }=-97.655 \mathrm{SA}_{\mathrm{i}}+-.007 \mathrm{SAGI}_{\mathrm{i}}+2.77 \mathrm{SGPA}+960.929 \mathrm{LOC}+1963.457 \mathrm{LOC}
$$

+749.78PROGN1 + 639.787PROGN2 + 1174.171PROGN3 + 677.087PROGN4 +

2214.238PROGN6 + 1106.578PROGN7 + 2763.367

\section{Research Question 5f: Do the amounts paid for institutional need-based financial}

grant aid paid by public institutions differ significantly from the amounts paid for institutional need-based financial grant aid by private institutions? Research Question 5 f relates to Hypothesis $\left(\mathrm{H}_{5 \mathrm{f}}\right)$, that the amount of institutional need-based financial grant aid paid per student by public institutions is less than or equal to the amount of institutional need-based financial grant aid paid per student by private institutions.

As described in Chapter 3, Equation 5f relates to Research Question 5f and Hypothesis 5f:

$$
\text { IFPBN } \leq \text { IFPVN }
$$

The data used for the means comparison are displayed in Table 67. The following formula was used to calculate the $t$ value:

$$
t_{d f}=\frac{\left|\bar{x}_{A}-\bar{x}_{B}\right|}{\sqrt{\hat{V}_{A}+\hat{V}_{B}}}
$$

The means for the two groups that were compared are represented by $\bar{x}_{A}$ and $\bar{x}_{B}$. The respective squared standard errors associated with the means are represented by $\hat{V}_{A}$ and $\hat{V}_{B}$.

The $t$ value for the comparison of the two means was 19.19. Because the test statistic exceeds the critical value of \pm 1.96 , the difference between the two means is statistically significant. 
Table 67: Equation $5 f$ group statistics

\begin{tabular}{|l|r|r|}
\hline & \multicolumn{1}{|c|}{ Mean } & Standard Error \\
\hline Public Institutions & 122.110 & 4.164 \\
\hline Private Institutions & 1685.560 & 81.356 \\
\hline
\end{tabular}

\section{Research Question 6a: Is there a relationship between the amount of state merit-based}

financial grant aid received per student at public institutions, the amount of tuition and the fees per student charged to in-state students, student characteristics and academic programs?

Research Question 6a relates to Hypothesis $\left(\mathrm{H}_{6 \mathrm{a}}\right)$, that there is no significant relationship between the amount of state merit-based financial grant aid received per student at public institutions, the amount of tuition and fees per student charged to in-state students, student characteristics and academic programs. As described in Chapter 3, Equation 6a relates to Research Question 6a and Hypothesis 6a:

$$
\mathrm{SFPBM}_{\mathrm{i}}=\mathrm{T}_{\mathrm{i}}+\mathrm{SA}_{\mathrm{i}}+\mathrm{SAGI}_{\mathrm{i}}+\mathrm{SR}_{\mathrm{i}}+\mathrm{SG}_{\mathrm{i}}+\mathrm{SPEL}_{\mathrm{i}}+\mathrm{SGPA}_{\mathrm{i}}+\mathrm{SVA}_{\mathrm{i}}+\mathrm{LOC}_{\mathrm{i}}+\mathrm{PROGN}_{\mathrm{i}}
$$

The significance scores for this equation are displayed in Table 68. The NCES' DAS was used to perform a weighted least squares computation using NPSAS: 04 data.

Table 68: Equation 6a hypothesis testing results

\begin{tabular}{|l|r|r|r|r|r|}
\hline & Wald $F$ & Num. DF & $\begin{array}{l}\text { Denom. } \\
\text { DF }\end{array}$ & Commonality & $\begin{array}{l}\text { Probability } \\
F\end{array}$ \\
\hline Overall Fit & 23.864 & 35 & 30 & & .001 \\
\hline Tuition and fees (T) & 20.960 & 1 & 64 & .001 & .001 \\
\hline Age (SA) & 297.779 & 1 & 64 & .010 & .001 \\
\hline $\begin{array}{l}\text { Adjusted Gross } \\
\text { Income (SAGI) }\end{array}$ & 14.704 & 1 & 64 & .001 & .001 \\
\hline Race (SR) & 1.896 & 5 & 60 & .000 & .108 \\
\hline Gender (SG) & .296 & 1 & 64 & .000 & .588 \\
\hline $\begin{array}{l}\text { Parent's highest } \\
\text { education level } \\
\text { (SPEL) }\end{array}$ & 2.544 & 10 & 55 & .001 & .013 \\
\hline $\begin{array}{l}\text { Grade point average } \\
\text { (SGPA) }\end{array}$ & 136.864 & 1 & 64 & .008 & .001 \\
\hline $\begin{array}{l}\text { Attend institution in } \\
\text { state of legal } \\
\text { residence (LOC) }\end{array}$ & 108.221 & 2 & 63 & .003 & .001 \\
\hline
\end{tabular}




\begin{tabular}{|l|r|r|r|r|r|}
\hline Veteran status (SVA) & .903 & 1 & 64 & .000 & .345 \\
\hline Program (PROGN) & 5.560 & 12 & 53 & .003 & .001 \\
\hline
\end{tabular}

The variables Race, (R), Gender (SG) and Veteran status (VA) were not significant.

Because they were not significant, a second computation was completed without these variables.

The significance scores for this computation are displayed in Table 69. The Wald F calculations for all the variables in this equation were significant. The regression coefficients from this equation and their related $t$ values are displayed in Table 70. The coefficients for the variables 2 or more years of college, Master's degree or equivalent, First professional degree, Attend institution in state of legal residence-no, Undeclared or not in a degree program, Social/behavioral sciences, Life sciences, Math, computer/information science, Education, Business/management and Vocational/technical were not significant. The coefficient of determination was .0284 . From this statistic, we may conclude that 2.8 percent of the variance in state merit-based financial grant aid per student paid by public institutions is explained by the independent variables in this equation.

Table 69: Equation 6a hypothesis testing results second calculation

\begin{tabular}{|l|r|r|r|r|r|}
\hline & Wald F & Num. DF & Denom. DF & Commonality & $\begin{array}{l}\text { Probability } \\
F\end{array}$ \\
\hline Overall Fit & 30.16 & 28 & 37 & & .001 \\
\hline Tuition and fees (T) & 21.805 & 1 & 64 & .000 & .001 \\
\hline Age (SA) & 280.243 & 1 & 64 & .010 & .001 \\
\hline $\begin{array}{l}\text { Adjusted Gross } \\
\text { Income (SAGI) }\end{array}$ & 14.713 & 1 & 64 & .001 & .001 \\
\hline $\begin{array}{l}\text { Parent's highest } \\
\text { education level } \\
\text { (SPEL) }\end{array}$ & 2.478 & 10 & 55 & .001 & .016 \\
\hline $\begin{array}{l}\text { Grade point average } \\
\text { (SGPA) }\end{array}$ & 154.459 & 1 & 64 & .008 & .001 \\
\hline $\begin{array}{l}\text { Attend institution in } \\
\text { state of legal } \\
\text { residence (LOC) }\end{array}$ & 119.173 & 2 & 63 & .003 & .001 \\
\hline Program (PROGN) & 6.030 & 12 & 53 & & .003 \\
\hline
\end{tabular}


Table 70: Equation 6a estimated full sample regression coefficients

\begin{tabular}{|c|c|c|c|c|}
\hline & $\mathrm{B}$ & s.e. & $T$ & Probability $t$ \\
\hline Intercept & 34.507 & 36.173 & 0.954 & .344 \\
\hline Tuition and fees (T) & -0.005 & .001 & -4.670 & .001 \\
\hline Age (SA) & -9.322 & .557 & -16.740 & .001 \\
\hline Adjusted Gross Income (SAGI) & .000 & .000 & 3.836 & .001 \\
\hline \multicolumn{5}{|l|}{ Parent's highest education level } \\
\hline $\begin{array}{l}\text { Do not know parent's education level } \\
\text { (SPEL1) }\end{array}$ & -72.460 & 35.030 & -2.068 & .043 \\
\hline Did not complete high school (SPEL2) & -58.038 & 28.121 & -2.064 & .043 \\
\hline $\begin{array}{l}\text { High school diploma or equivalent } \\
\text { (SPEL3) }\end{array}$ & -76.771 & 25.148 & -3.053 & .003 \\
\hline $\begin{array}{l}\text { Vocational or technical training } \\
\text { (SPEL4) }\end{array}$ & -75.450 & 28.321 & -2.664 & .010 \\
\hline $\begin{array}{l}\text { Less than two years of college } \\
\text { (SPEL5) }\end{array}$ & -89.936 & 26.450 & -3.400 & .001 \\
\hline Associate's degree (SPEL6) & -77.509 & 32.243 & -2.404 & .019 \\
\hline $\begin{array}{l}2 \text { or more years of college but no } \\
\text { degree (SPEL 7) }\end{array}$ & -42.552 & 37.520 & -1.134 & .261 \\
\hline Bachelor's degree (SPEL8) & -69.251 & 28.503 & -2.430 & .018 \\
\hline Master's degree or equivalent (SPEL9) & -41.716 & 25.706 & -1.623 & .110 \\
\hline First-professional degree (SPEL10) & -15.506 & 44.260 & -0.350 & .727 \\
\hline \multicolumn{5}{|l|}{ vs. Doctoral degree or equivalent } \\
\hline Grade point average (SGPA) & .818 & .066 & 12.428 & .001 \\
\hline \multicolumn{5}{|l|}{$\begin{array}{l}\text { Attend institution in state of legal } \\
\text { residence }\end{array}$} \\
\hline Yes (LOC1) & 124.051 & 9.382 & 13.222 & .001 \\
\hline No (LOC2) & .281 & 8.937 & .031 & .975 \\
\hline \multicolumn{5}{|l|}{ vs. Foreign or international student } \\
\hline \multicolumn{5}{|l|}{ Program } \\
\hline $\begin{array}{l}\text { Undeclared or not in a degree program } \\
\text { (PROGN1) }\end{array}$ & -9.855 & 11.888 & -.829 & .410 \\
\hline Humanities (PROGN2) & -29.544 & 10.562 & -2.797 & .007 \\
\hline Social/behavioral sciences (PROGN3) & 3.809 & 18.146 & .210 & .834 \\
\hline Life sciences (PROGN4) & 24.574 & 20.901 & 1.176 & .244 \\
\hline Physical sciences (PROGN5) & 81.345 & 34.296 & 2.372 & .021 \\
\hline Math (PROGN6) & 120.471 & 77.291 & 1.559 & .124 \\
\hline $\begin{array}{l}\text { Computer/information science } \\
\text { (PROGN7) }\end{array}$ & 8.470 & 19.027 & .445 & .658 \\
\hline Engineering (PROGN8) & 61.614 & 22.151 & 2.782 & .007 \\
\hline Education (PROGN9) & 23.552 & 22.790 & 1.033 & .305 \\
\hline Business/management (PROGN10) & 15.654 & 13.939 & 1.123 & .266 \\
\hline Health (PROGN11) & 79.395 & 23.182 & 3.425 & .001 \\
\hline Vocational/technical (PROGN12) & -12.421 & 34.906 & -.356 & .723 \\
\hline
\end{tabular}


vs. Other technical/professional

The correlations for this equation are displayed in Table 71.

Table 71: Equation 6a correlations

\begin{tabular}{|c|c|c|c|c|c|c|}
\hline & $\begin{array}{l}\text { State } \\
\text { merit- } \\
\text { only } \\
\text { grants }\end{array}$ & & $\begin{array}{l}\text { Age as } \\
\text { of } \\
12 / 31 / 03\end{array}$ & $\begin{array}{l}\text { Adjusted } \\
\text { Gross } \\
\text { Income } \\
\text { (AGI) }\end{array}$ & $\begin{array}{l}\text { Do not } \\
\text { know } \\
\text { parent's } \\
\text { education } \\
\text { level }\end{array}$ & $\begin{array}{l}\text { Did not } \\
\text { complete } \\
\text { high } \\
\text { school }\end{array}$ \\
\hline $\begin{array}{l}\text { State merit- } \\
\text { only grants } \\
\text { (SFPBM) }\end{array}$ & 1 & -.017 & -.09 & .052 & -.014 & -.015 \\
\hline $\begin{array}{l}\text { Tuition and } \\
\text { Fees (T) }\end{array}$ & -.017 & 1 & -.263 & .163 & -.013 & -.065 \\
\hline Age (SA) & -.094 & -.263 & 1 & -.181 & .069 & .151 \\
\hline $\begin{array}{l}\text { Adjusted } \\
\text { Gross Income } \\
\text { (SAGI) }\end{array}$ & .052 & .163 & -.181 & 1 & -.065 & -.106 \\
\hline $\begin{array}{l}\text { Do not know } \\
\text { parent's } \\
\text { education } \\
\text { level } \\
\text { (SPEL1) }\end{array}$ & -.014 & -.013 & .069 & -.065 & 1 & -.026 \\
\hline $\begin{array}{l}\text { Did not } \\
\text { complete } \\
\text { high school } \\
\text { (SPEL2) }\end{array}$ & -.015 & -.065 & .151 & -.106 & -.026 & 1 \\
\hline $\begin{array}{l}\text { High school } \\
\text { diploma or } \\
\text { equivalent } \\
\text { (SPEL3) }\end{array}$ & -.031 & -.083 & .125 & -.154 & -.069 & -.107 \\
\hline $\begin{array}{l}\text { Vocational or } \\
\text { technical } \\
\text { training } \\
\text { (SPEL4) }\end{array}$ & -.004 & -.008 & .026 & -.018 & -.025 & -.039 \\
\hline $\begin{array}{l}\text { Less than two } \\
\text { years of } \\
\text { college } \\
\text { (SPEL5) }\end{array}$ & -.012 & -.016 & -.004 & -.044 & -.035 & -.054 \\
\hline $\begin{array}{l}\text { Associate's } \\
\text { degree }\end{array}$ & -.005 & -.020 & -.004 & -.020 & -.037 & -.056 \\
\hline
\end{tabular}




\begin{tabular}{|c|c|c|c|c|c|c|}
\hline (SPEL6) & & & & & & \\
\hline $\begin{array}{l}2 \text { or more } \\
\text { years of } \\
\text { college but } \\
\text { no degree } \\
\text { (SPEL7) } \\
\end{array}$ & .006 & -.026 & .011 & -.039 & -.028 & -.044 \\
\hline $\begin{array}{l}\text { Bachelor's } \\
\text { degree } \\
\text { (SPEL8) } \\
\end{array}$ & .005 & .038 & -.100 & .096 & -.077 & -.118 \\
\hline $\begin{array}{l}\text { Master's } \\
\text { degree or } \\
\text { equivalent } \\
\text { (SPEL9) }\end{array}$ & .028 & .077 & -.098 & .125 & -.059 & -.090 \\
\hline $\begin{array}{l}\text { First- } \\
\text { professional } \\
\text { degree } \\
\text { (SPEL10) }\end{array}$ & .018 & .041 & -.033 & .058 & -.021 & -.032 \\
\hline $\begin{array}{l}\text { Grade point } \\
\text { average } \\
\text { (SGPA) } \\
\end{array}$ & .082 & .063 & .133 & .048 & -.027 & -.004 \\
\hline $\begin{array}{l}\text { Attend } \\
\text { institution in } \\
\text { state of legal } \\
\text { residence } \\
=\text { Yes (LOC1) }\end{array}$ & .061 & -.559 & .095 & -.076 & .010 & .032 \\
\hline $\begin{array}{l}\text { Attend } \\
\text { institution in } \\
\text { state of legal } \\
\text { residence=No } \\
\text { (LOC2) }\end{array}$ & -.054 & .524 & -.097 & .099 & -.019 & -.035 \\
\hline $\begin{array}{l}\text { Undeclared } \\
\text { or not in a } \\
\text { degree } \\
\text { program } \\
\text { (PROGN1) }\end{array}$ & -.016 & -.078 & .001 & .010 & -.002 & .009 \\
\hline $\begin{array}{l}\text { Humanities } \\
\text { (PROGN2) }\end{array}$ & -.024 & -.002 & .008 & -.008 & .006 & -.011 \\
\hline $\begin{array}{l}\text { Social/ } \\
\text { behavioral } \\
\text { sciences } \\
\text { (PROGN3) }\end{array}$ & -.004 & .020 & -.017 & -.011 & -.003 & -.003 \\
\hline $\begin{array}{l}\text { Life sciences } \\
\text { (PROGN4) }\end{array}$ & .009 & .046 & -.047 & .002 & -.015 & -.021 \\
\hline
\end{tabular}




\begin{tabular}{|l|r|r|r|r|r|r|}
\hline $\begin{array}{l}\text { Physical } \\
\text { sciences } \\
\text { (PROGN5) }\end{array}$ & .014 & .013 & -.004 & -.004 & .011 & -.015 \\
\hline $\begin{array}{l}\text { Math } \\
\text { (PROGN6) }\end{array}$ & .015 & .014 & -.004 & -.001 & -.002 & .012 \\
\hline $\begin{array}{l}\text { Computer/ } \\
\text { information } \\
\text { science } \\
\text { (PROGN7) }\end{array}$ & -.006 & -.010 & .018 & -.006 & .010 & -.010 \\
\hline $\begin{array}{l}\text { Engineering } \\
\text { (PROGN8) }\end{array}$ & .021 & .083 & -.041 & .031 & -.013 & -.011 \\
\hline $\begin{array}{l}\text { Education } \\
\text { (PROGN9) }\end{array}$ & .010 & -.016 & .023 & -.014 & .001 & .007 \\
\hline $\begin{array}{l}\text { Business/ } \\
\text { management } \\
\text { (PROGN10) }\end{array}$ & -.004 & -.007 & .016 & .005 & .011 & .013 \\
\hline $\begin{array}{l}\text { Health } \\
\text { (PROGN11) }\end{array}$ & .032 & -.033 & .038 & -.019 & .003 & .023 \\
\hline $\begin{array}{l}\text { Vocational/ } \\
\text { technical } \\
\text { (PROGN12) }\end{array}$ & -.010 & .013 & .012 & .001 & -.002 & .001 \\
\hline
\end{tabular}

Table 71: Equation 6a correlations (continued)

\begin{tabular}{|c|c|c|c|c|c|}
\hline & $\begin{array}{l}\text { High } \\
\text { school } \\
\text { diploma or } \\
\text { equivalent }\end{array}$ & $\begin{array}{l}\text { Vocational } \\
\text { or technical } \\
\text { training }\end{array}$ & $\begin{array}{l}\text { Less } \\
\text { than two } \\
\text { years of } \\
\text { college }\end{array}$ & $\begin{array}{l}\text { Associate's } \\
\text { degree }\end{array}$ & $\begin{array}{l}2 \text { or } \\
\text { more } \\
\text { years of } \\
\text { college } \\
\text { but no } \\
\text { degree }\end{array}$ \\
\hline $\begin{array}{l}\text { State merit- } \\
\text { only grants } \\
(\mathrm{SFPBM})\end{array}$ & -.031 & -.004 & -.012 & -.005 & .006 \\
\hline $\begin{array}{l}\text { Tuition and } \\
\text { fees (T) }\end{array}$ & -.083 & -.008 & -.016 & -.020 & -.026 \\
\hline Age (SA) & .125 & .026 & -.004 & -.004 & .011 \\
\hline $\begin{array}{l}\text { Adjusted } \\
\text { Gross Income } \\
\text { (SAGI) }\end{array}$ & -.154 & -.018 & -.044 & -.020 & -.039 \\
\hline $\begin{array}{l}\text { Do not know } \\
\text { parent's } \\
\text { education } \\
\text { level } \\
\text { (SPEL1) }\end{array}$ & -.069 & -.025 & -.035 & -.037 & -.028 \\
\hline
\end{tabular}




\begin{tabular}{|c|c|c|c|c|c|}
\hline $\begin{array}{l}\text { Did not } \\
\text { complete } \\
\text { high school } \\
\text { (SPEL2) }\end{array}$ & -.107 & -.039 & -.054 & -.056 & -.044 \\
\hline $\begin{array}{l}\text { High school } \\
\text { diploma or } \\
\text { equivalent } \\
\text { (SPEL3) }\end{array}$ & 1 & -.104 & -.145 & -.150 & -.116 \\
\hline $\begin{array}{l}\text { Vocational or } \\
\text { technical } \\
\text { training } \\
\text { (SPEL4) }\end{array}$ & -.104 & 1 & -.053 & -.055 & -.042 \\
\hline $\begin{array}{l}\text { Less than two } \\
\text { years of } \\
\text { college } \\
\text { (SPEL5) }\end{array}$ & -.145 & -.053 & 1 & -.077 & -.059 \\
\hline $\begin{array}{l}\text { Associate's } \\
\text { degree } \\
\text { (SPEL6) }\end{array}$ & -.150 & -.055 & -.077 & 1 & -.061 \\
\hline $\begin{array}{l}2 \text { or more } \\
\text { years of } \\
\text { college but } \\
\text { no degree } \\
\text { (SPEL7) } \\
\end{array}$ & -.116 & -.043 & -.059 & -.061 & 1 \\
\hline $\begin{array}{l}\text { Bachelor's } \\
\text { degree } \\
\text { (SPEL8) } \\
\end{array}$ & -.316 & -.116 & -.161 & -.167 & -.129 \\
\hline $\begin{array}{l}\text { Master's } \\
\text { degree or } \\
\text { equivalent } \\
\text { (SPEL9) }\end{array}$ & -.241 & -.088 & -.123 & -.127 & -.098 \\
\hline $\begin{array}{l}\text { First- } \\
\text { professional } \\
\text { degree } \\
\text { (SPEL10) } \\
\end{array}$ & -.086 & -.032 & -.044 & -.046 & -.035 \\
\hline $\begin{array}{l}\text { Grade point } \\
\text { average } \\
\text { (SGPA) }\end{array}$ & -.045 & .025 & -.018 & -.008 & -.006 \\
\hline $\begin{array}{l}\text { Attend } \\
\text { institution in } \\
\text { state of legal } \\
\text { residence= } \\
\text { Yes (LOC1) }\end{array}$ & .040 & .002 & .030 & .016 & .023 \\
\hline
\end{tabular}




\begin{tabular}{|c|c|c|c|c|c|}
\hline $\begin{array}{l}\text { Attend } \\
\text { institution in } \\
\text { state of legal } \\
\text { residence=No } \\
\text { (LOC2) }\end{array}$ & -.039 & -.011 & -.023 & -.019 & -.017 \\
\hline $\begin{array}{l}\text { Undeclared } \\
\text { or not in a } \\
\text { degree } \\
\text { program } \\
\text { (PROGN1) }\end{array}$ & .006 & -.001 & -.009 & -.019 & .003 \\
\hline $\begin{array}{l}\text { Humanities } \\
\text { (PROGN2) }\end{array}$ & -.007 & -.004 & -.007 & -.006 & -.002 \\
\hline $\begin{array}{l}\text { Social/ } \\
\text { behavioral } \\
\text { sciences } \\
\text { (PROGN3) }\end{array}$ & -.009 & -.014 & .002 & -.005 & .018 \\
\hline $\begin{array}{l}\text { Life sciences } \\
\text { (PROGN4) }\end{array}$ & -.014 & .007 & -.011 & -.013 & -.001 \\
\hline $\begin{array}{l}\text { Physical } \\
\text { sciences } \\
\text { (PROGN5) }\end{array}$ & -.006 & -.009 & .002 & .003 & -.009 \\
\hline $\begin{array}{l}\text { Math } \\
\text { (PROGN6) }\end{array}$ & -.004 & .005 & -.006 & .026 & -.016 \\
\hline $\begin{array}{l}\text { Computer/ } \\
\text { information } \\
\text { science } \\
\text { (PROGN7) }\end{array}$ & -.001 & .013 & -.018 & -.006 & -.011 \\
\hline $\begin{array}{l}\text { Engineering } \\
\text { (PROGN8) }\end{array}$ & -.038 & -.002 & -.006 & -.003 & -.007 \\
\hline $\begin{array}{l}\text { Education } \\
\text { (PROGN9) }\end{array}$ & .025 & -.008 & .041 & -.007 & .005 \\
\hline $\begin{array}{l}\text { Business/ } \\
\text { management } \\
(\text { PROGN10) }\end{array}$ & .010 & -.001 & -.005 & .016 & -.005 \\
\hline $\begin{array}{l}\text { Health } \\
(\text { PROGN11) }\end{array}$ & .008 & .021 & .014 & .013 & .006 \\
\hline $\begin{array}{l}\text { Vocational/ } \\
\text { technical } \\
\text { (PROGN12) }\end{array}$ & .005 & -.004 & .002 & -.007 & -.011 \\
\hline
\end{tabular}


Table 71: Equation 6a correlations (continued)

\begin{tabular}{|c|c|c|c|c|c|}
\hline & $\begin{array}{l}\text { Bachelor's } \\
\text { degree }\end{array}$ & $\begin{array}{l}\text { Master's } \\
\text { degree or } \\
\text { equivalent }\end{array}$ & $\begin{array}{l}\text { First- } \\
\text { professional } \\
\text { degree }\end{array}$ & $\begin{array}{l}\text { Grade } \\
\text { point } \\
\text { average }\end{array}$ & $\begin{array}{l}\text { Attend } \\
\text { institution in } \\
\text { state of } \\
\text { legal } \\
\text { residence } \\
=\text { Yes }\end{array}$ \\
\hline $\begin{array}{l}\text { State merit- } \\
\text { only grants } \\
\text { (SFPBM) }\end{array}$ & .005 & .028 & .018 & .082 & .061 \\
\hline $\begin{array}{l}\text { Tuition and } \\
\text { fees }(\mathrm{T})\end{array}$ & .038 & .077 & .041 & .063 & -.559 \\
\hline Age (SA) & -.100 & $\begin{array}{l}.098 \\
\end{array}$ & -.033 & .133 & .095 \\
\hline $\begin{array}{l}\text { Adjusted } \\
\text { Gross Income } \\
\text { (SAGI) }\end{array}$ & .096 & .125 & .058 & .048 & -.076 \\
\hline $\begin{array}{l}\text { Do not know } \\
\text { parent's } \\
\text { education } \\
\text { level } \\
\text { (SPEL1) } \\
\end{array}$ & -.077 & -.059 & -.021 & -.027 & .010 \\
\hline $\begin{array}{l}\text { Did not } \\
\text { complete } \\
\text { high school } \\
\text { (SPEL2) }\end{array}$ & -.118 & -.090 & -.032 & -.004 & .032 \\
\hline $\begin{array}{l}\text { High school } \\
\text { diploma or } \\
\text { equivalent } \\
\text { (SPEL3) }\end{array}$ & -.316 & -.241 & -.086 & -.045 & .040 \\
\hline $\begin{array}{l}\text { Vocational or } \\
\text { technical } \\
\text { training } \\
\text { (SPEL4) } \\
\end{array}$ & -.116 & $\begin{array}{l}.088 \\
\end{array}$ & -.032 & .025 & .002 \\
\hline $\begin{array}{l}\text { Less than two } \\
\text { years of } \\
\text { college } \\
\text { (SPEL5) }\end{array}$ & -.161 & -.123 & -.044 & -.018 & .030 \\
\hline $\begin{array}{l}\text { Associate's } \\
\text { degree } \\
\text { (SPEL6) }\end{array}$ & -.167 & -.127 & -.046 & -.008 & .016 \\
\hline
\end{tabular}




\begin{tabular}{|c|c|c|c|c|c|}
\hline $\begin{array}{l}2 \text { or more } \\
\text { years of } \\
\text { college but } \\
\text { no degree } \\
\text { (SPEL7) }\end{array}$ & -.129 & -.098 & -.035 & -.006 & .023 \\
\hline $\begin{array}{l}\text { Bachelor's } \\
\text { degree } \\
\text { (SPEL8) }\end{array}$ & 1 & -.267 & -.096 & .005 & -.030 \\
\hline $\begin{array}{l}\text { Master's } \\
\text { degree or } \\
\text { equivalent } \\
\text { (SPEL9) }\end{array}$ & -.267 & 1 & -.073 & .037 & $\begin{array}{l}.049 \\
\end{array}$ \\
\hline $\begin{array}{l}\text { First- } \\
\text { professional } \\
\text { degree } \\
\text { (SPEL10) } \\
\end{array}$ & $\begin{array}{l}.096 \\
\end{array}$ & -.073 & 1 & .033 & -.019 \\
\hline $\begin{array}{l}\text { Grade point } \\
\text { average } \\
\text { (SGPA) }\end{array}$ & .005 & .037 & .033 & 1 & -.023 \\
\hline $\begin{array}{l}\text { Attend } \\
\text { institution in } \\
\text { state of legal } \\
\text { residence } \\
=\text { Yes (LOC1) }\end{array}$ & -.030 & -.049 & $\begin{array}{l}.019 \\
\end{array}$ & -.023 & 1 \\
\hline $\begin{array}{l}\text { Attend } \\
\text { institution in } \\
\text { state of legal } \\
\text { residence=No } \\
\text { (LOC2) }\end{array}$ & .028 & .055 & .017 & .008 & $\begin{array}{c}-.906 \\
\end{array}$ \\
\hline $\begin{array}{l}\text { Undeclared } \\
\text { or not in a } \\
\text { degree } \\
\text { program } \\
\text { (PROGN1) }\end{array}$ & .003 & -.007 & .016 & -.053 & .015 \\
\hline $\begin{array}{l}\text { Humanities } \\
\text { (PROGN2) }\end{array}$ & -.007 & .021 & .010 & .023 & $\begin{array}{c}.008 \\
\end{array}$ \\
\hline $\begin{array}{l}\text { Social/ } \\
\text { behavioral } \\
\text { sciences } \\
\text { (PROGN3) }\end{array}$ & -.008 & .009 & .005 & -.008 & .016 \\
\hline $\begin{array}{l}\text { Life sciences } \\
\text { (PROGN4) }\end{array}$ & .017 & .011 & .012 & .006 & $\begin{array}{l}-.016 \\
\end{array}$ \\
\hline $\begin{array}{l}\text { Physical } \\
\text { sciences } \\
\text { (PROGN5) }\end{array}$ & -.005 & .015 & .003 & .014 & $\begin{array}{l}.001 \\
\end{array}$ \\
\hline
\end{tabular}




\begin{tabular}{|l|c|c|c|c|c|}
\hline $\begin{array}{l}\text { Math } \\
\text { (PROGN6) }\end{array}$ & -.001 & -.007 & -.001 & .002 & -.006 \\
\hline $\begin{array}{l}\text { Computer/ } \\
\text { information } \\
\text { science } \\
\text { (PROGN7) }\end{array}$ & .013 & -.001 & .013 & -.024 & -.004 \\
\hline $\begin{array}{l}\text { Engineering } \\
\text { (PROGN8) }\end{array}$ & .020 & .022 & .013 & -.008 & -.048 \\
\hline $\begin{array}{l}\text { Education } \\
\text { (PROGN9) }\end{array}$ & -.014 & -.016 & -.011 & .066 & .041 \\
\hline $\begin{array}{l}\text { Business/ } \\
\text { management } \\
\text { (PROGN10) }\end{array}$ & -.001 & -.003 & -.033 & -.026 & -.006 \\
\hline $\begin{array}{l}\text { Health } \\
\text { (PROGN11) }\end{array}$ & -.015 & -.026 & -.007 & .046 & .023 \\
\hline $\begin{array}{l}\text { Vocational/ } \\
\text { technical } \\
\text { (PROGN12) }\end{array}$ & .006 & .005 & -.008 & -.004 & -.038 \\
\hline
\end{tabular}

Table 71: Equation 6a correlations (continued)

\begin{tabular}{|l|l|l|r|r|r|r|}
\hline & $\begin{array}{l}\text { Attend } \\
\text { institution } \\
\text { in state of } \\
\text { legal } \\
\text { residence } \\
\text { No }\end{array}$ & $\begin{array}{l}\text { Undeclared } \\
\text { or not in a } \\
\text { degree } \\
\text { program }\end{array}$ & Humanities & $\begin{array}{l}\text { Social/ } \\
\text { behavioral } \\
\text { sciences }\end{array}$ & $\begin{array}{l}\text { Life } \\
\text { sciences }\end{array}$ & $\begin{array}{l}\text { Physical } \\
\text { sciences }\end{array}$ \\
\hline $\begin{array}{l}\text { State merit- } \\
\text { only grants } \\
\text { (SFPBM) }\end{array}$ & -.054 & -.016 & -.024 & -.004 & .009 & .014 \\
\hline $\begin{array}{l}\text { Tuition and } \\
\text { fees (T) }\end{array}$ & .524 & -.078 & -.002 & .020 & .046 & .013 \\
\hline Age (SA) & -.097 & .001 & .008 & -.017 & -.047 & -.004 \\
\hline $\begin{array}{l}\text { Adjusted } \\
\text { Gross Income } \\
\text { (SAGI) }\end{array}$ & .099 & .010 & -.008 & -.011 & .002 & -.004 \\
\hline $\begin{array}{l}\text { Do not know } \\
\text { parent's } \\
\text { education } \\
\text { level } \\
\text { (SPEL1) }\end{array}$ & -.019 & -.002 & .006 & -.003 & -.015 & .011 \\
\hline
\end{tabular}




\begin{tabular}{|c|c|c|c|c|c|c|}
\hline $\begin{array}{l}\text { Did not } \\
\text { complete } \\
\text { high school } \\
\text { (SPEL2) }\end{array}$ & -.035 & .009 & -.011 & -.003 & -.021 & -.015 \\
\hline $\begin{array}{l}\text { High school } \\
\text { diploma or } \\
\text { equivalent } \\
\text { (SPEL3) }\end{array}$ & -.039 & .006 & -.007 & -.009 & -.014 & -.006 \\
\hline $\begin{array}{l}\text { Vocational or } \\
\text { technical } \\
\text { training } \\
\text { (SPEL4) } \\
\end{array}$ & -.011 & -.001 & -.004 & -.014 & .007 & -.009 \\
\hline $\begin{array}{l}\text { Less than two } \\
\text { years of } \\
\text { college } \\
\text { (SPEL5) }\end{array}$ & -.023 & -.009 & -.007 & .002 & -.011 & .002 \\
\hline $\begin{array}{l}\text { Associate's } \\
\text { degree } \\
\text { (SPEL6) } \\
\end{array}$ & -.019 & -.019 & -.006 & -.005 & -.013 & .003 \\
\hline $\begin{array}{l}2 \text { or more } \\
\text { years of } \\
\text { college but } \\
\text { no degree } \\
\text { (SPEL7) }\end{array}$ & -.017 & .003 & -.002 & .018 & -.001 & -.009 \\
\hline $\begin{array}{l}\text { Bachelor's } \\
\text { degree } \\
\text { (SPEL8) }\end{array}$ & .028 & .003 & -.007 & -.008 & .017 & -.005 \\
\hline $\begin{array}{l}\text { Master's } \\
\text { degree or } \\
\text { equivalent } \\
\text { (SPEL9) }\end{array}$ & .055 & -.007 & .021 & .009 & .011 & .015 \\
\hline $\begin{array}{l}\text { First- } \\
\text { professional } \\
\text { degree } \\
\text { (SPEL10) } \\
\end{array}$ & .017 & .016 & .010 & .005 & .012 & .003 \\
\hline $\begin{array}{l}\text { Grade point } \\
\text { average } \\
\text { (SGPA) }\end{array}$ & .008 & -.053 & .023 & -.008 & .006 & .014 \\
\hline $\begin{array}{l}\text { Attend } \\
\text { institution in } \\
\text { state of legal } \\
\text { residence } \\
=\text { Yes (LOC1) }\end{array}$ & -.906 & .015 & -.008 & .016 & -.016 & -.001 \\
\hline
\end{tabular}




\begin{tabular}{|c|c|c|c|c|c|c|}
\hline $\begin{array}{l}\text { Attend } \\
\text { institution in } \\
\text { state of legal } \\
\text { residence=No } \\
\text { (LOC2) }\end{array}$ & 1 & -.012 & .009 & -.011 & .014 & .002 \\
\hline $\begin{array}{l}\text { Undeclared } \\
\text { or not in a } \\
\text { degree } \\
\text { program } \\
\text { (PROGN1) }\end{array}$ & -.012 & 1 & -.133 & -.139 & -.104 & -.042 \\
\hline $\begin{array}{l}\text { Humanities } \\
\text { (PROGN2) }\end{array}$ & .009 & -.133 & 1 & -.130 & -.097 & -.039 \\
\hline $\begin{array}{l}\text { Social/ } \\
\text { behavioral } \\
\text { sciences } \\
\text { (PROGN3) }\end{array}$ & -.011 & -.139 & -.130 & 1 & -.102 & -.041 \\
\hline $\begin{array}{l}\text { Life sciences } \\
\text { (PROGN4) }\end{array}$ & .014 & -.104 & -.097 & -.102 & 1 & -.031 \\
\hline $\begin{array}{l}\text { Physical } \\
\text { sciences } \\
\text { (PROGN5) }\end{array}$ & .002 & -.042 & -.039 & -.041 & -.031 & 1 \\
\hline $\begin{array}{l}\text { Math } \\
\text { (PROGN6) }\end{array}$ & .001 & -.034 & -.032 & -.033 & -.0248 & $\begin{array}{l}-.0099 \\
\end{array}$ \\
\hline $\begin{array}{l}\text { Computer/ } \\
\text { information } \\
\text { science } \\
\text { (PROGN7) }\end{array}$ & -.006 & -.078 & -.073 & -.077 & -.058 & -.023 \\
\hline $\begin{array}{l}\text { Engineering } \\
\text { (PROGN8) }\end{array}$ & .041 & -.097 & $\begin{array}{l}-.091 \\
\end{array}$ & -.095 & -.071 & -.029 \\
\hline $\begin{array}{l}\text { Education } \\
\text { (PROGN9) }\end{array}$ & -.033 & -.124 & -.116 & -.121 & -.091 & -.036 \\
\hline $\begin{array}{l}\text { Business/ } \\
\text { management } \\
\text { (PROGN10) }\end{array}$ & -.011 & -.164 & -.153 & -.160 & -.120 & -.048 \\
\hline $\begin{array}{l}\text { Health } \\
\text { (PROGN11) }\end{array}$ & -.014 & -.107 & -.100 & -.104 & -.078 & -.031 \\
\hline $\begin{array}{l}\text { Vocational/ } \\
\text { technical } \\
\text { (PROGN12) }\end{array}$ & .044 & -.042 & -.039 & -.041 & -.031 & -.012 \\
\hline
\end{tabular}


Table 71: Equation 6a correlations (continued)

\begin{tabular}{|c|c|c|c|c|c|c|}
\hline & Math & $\begin{array}{l}\text { Computer/ } \\
\text { information } \\
\text { science }\end{array}$ & Engineering & Education & $\begin{array}{l}\text { Business/ } \\
\text { management }\end{array}$ & Health \\
\hline $\begin{array}{l}\text { State merit- } \\
\text { only grants } \\
\text { (SFPBM) }\end{array}$ & .015 & -.006 & .021 & .010 & -.004 & .032 \\
\hline $\begin{array}{l}\text { Tuition and } \\
\text { fees }(\mathrm{T})\end{array}$ & .014 & -.010 & .083 & -.016 & -.007 & -.033 \\
\hline Age (SA) & -.004 & .018 & $\overline{-.041}$ & .023 & .016 & .038 \\
\hline $\begin{array}{l}\text { Adjusted } \\
\text { Gross Income } \\
\text { (SAGI) }\end{array}$ & -.001 & -.006 & .031 & -.014 & .005 & -.019 \\
\hline $\begin{array}{l}\text { Do not know } \\
\text { parent's } \\
\text { education } \\
\text { level } \\
\text { (SPEL1) }\end{array}$ & -.002 & .010 & -.013 & .001 & .011 & .003 \\
\hline $\begin{array}{l}\text { Did not } \\
\text { complete } \\
\text { high school } \\
\text { (SPEL2) }\end{array}$ & .012 & -.010 & -.011 & .007 & .013 & .023 \\
\hline $\begin{array}{l}\text { High school } \\
\text { diploma or } \\
\text { equivalent } \\
\text { (SPEL3) }\end{array}$ & -.004 & -.001 & -.038 & .025 & .001 & .008 \\
\hline $\begin{array}{l}\text { Vocational or } \\
\text { technical } \\
\text { training } \\
\text { (SPEL4) } \\
\end{array}$ & .005 & .013 & -.002 & -.008 & $\begin{array}{l}-.001 \\
\end{array}$ & .021 \\
\hline $\begin{array}{l}\text { Less than two } \\
\text { years of } \\
\text { college } \\
\text { (SPEL5) }\end{array}$ & -.006 & -.018 & -.006 & .041 & -.005 & .014 \\
\hline $\begin{array}{l}\text { Associate's } \\
\text { degree } \\
\text { (SPEL6) }\end{array}$ & .026 & -.006 & -.003 & -.007 & .016 & .013 \\
\hline $\begin{array}{l}2 \text { or more } \\
\text { years of } \\
\text { college but } \\
\text { no degree }\end{array}$ & -.016 & -.011 & -.007 & .005 & -.005 & .006 \\
\hline
\end{tabular}




\begin{tabular}{|c|c|c|c|c|c|c|}
\hline (SPEL7) & & & & & & \\
\hline $\begin{array}{l}\begin{array}{l}\text { Bachelor's } \\
\text { degree } \\
\text { (SPEL8) }\end{array} \\
\end{array}$ & $\begin{array}{l}.001 \\
\end{array}$ & .013 & .020 & -.014 & -.001 & $\overline{-.016}$ \\
\hline $\begin{array}{l}\text { Master's } \\
\text { degree or } \\
\text { equivalent } \\
\text { (SPEL9) }\end{array}$ & -.007 & -.001 & .022 & -.016 & -.003 & -.026 \\
\hline $\begin{array}{l}\text { First- } \\
\text { professional } \\
\text { degree } \\
\text { (SPEL10) }\end{array}$ & -.001 & .013 & .013 & -.011 & -.033 & -.007 \\
\hline $\begin{array}{l}\text { Grade point } \\
\text { average } \\
\text { (SGPA) }\end{array}$ & .002 & -.024 & -.008 & .066 & -.026 & .046 \\
\hline $\begin{array}{l}\text { Attend } \\
\text { institution in } \\
\text { state of legal } \\
\text { residence } \\
=\text { Yes (LOC1) }\end{array}$ & -.006 & -.004 & -.048 & .041 & -.006 & .023 \\
\hline $\begin{array}{l}\text { Attend } \\
\text { institution in } \\
\text { state of legal } \\
\text { residence=No } \\
\text { (LOC2) }\end{array}$ & .001 & -.006 & .041 & -.033 & -.011 & -.014 \\
\hline $\begin{array}{l}\text { Undeclared } \\
\text { or not in a } \\
\text { degree } \\
\text { program } \\
\text { (PROGN1) }\end{array}$ & -.034 & -.078 & -.097 & -.124 & -.164 & -.107 \\
\hline $\begin{array}{l}\text { Humanities } \\
\text { (PROGN2) }\end{array}$ & -.032 & -.073 & -.091 & -.116 & -.153 & -.100 \\
\hline $\begin{array}{l}\text { Social/ } \\
\text { behavioral } \\
\text { sciences } \\
\text { (PROGN3) } \\
\text { Life sciences } \\
\text { (PROGN4) } \\
\end{array}$ & -.025 & -.058 & -.071 & -.091 & -.120 & -.078 \\
\hline $\begin{array}{l}\text { Physical } \\
\text { sciences } \\
\text { (PROGN5) } \\
\end{array}$ & -.010 & -.023 & -.0290 & -.036 & $\begin{array}{l}-.048 \\
\end{array}$ & -.031 \\
\hline
\end{tabular}




\begin{tabular}{|l|r|r|r|r|r|r|}
\hline $\begin{array}{l}\text { Math } \\
\text { (PROGN6) }\end{array}$ & 1 & -.019 & -.023 & -.029 & -.039 & -.025 \\
\hline $\begin{array}{l}\text { Computer/ } \\
\text { information } \\
\text { science } \\
\text { (PROGN7) }\end{array}$ & -.019 & 1 & -.054 & -.068 & -.091 & -.059 \\
\hline $\begin{array}{l}\text { Engineering } \\
\text { (PROGN8) }\end{array}$ & -.023 & -.054 & 1 & -.085 & -.112 & -.073 \\
\hline $\begin{array}{l}\text { Education } \\
\text { (PROGN9) }\end{array}$ & -.029 & -.068 & -.085 & 1 & -.143 & -.093 \\
\hline $\begin{array}{l}\text { Business/ } \\
\text { management } \\
\text { (PROGN10) }\end{array}$ & -.039 & -.091 & -.112 & -.143 & 1 & -.123 \\
\hline $\begin{array}{l}\text { Health } \\
\text { (PROGN11) }\end{array}$ & -.025 & -.059 & -.073 & -.093 & -.123 & 1 \\
\hline $\begin{array}{l}\text { Vocational/ } \\
\text { technical } \\
\text { (PROGN12) }\end{array}$ & -.010 & -.023 & -.029 & -.036 & -.048 & -.031 \\
\hline
\end{tabular}

Table 71: Equation 6a correlations (continued)

\begin{tabular}{|l|r|}
\hline & $\begin{array}{l}\text { Vocational/ } \\
\text { technical }\end{array}$ \\
\hline $\begin{array}{l}\text { State merit- } \\
\text { only grants } \\
\text { (SFPBM) }\end{array}$ & -0.010 \\
\hline $\begin{array}{l}\text { Tuition and } \\
\text { fees (T) }\end{array}$ & .013 \\
\hline Age (SA) & .012 \\
\hline $\begin{array}{l}\text { Adjusted } \\
\text { Gross Income } \\
\text { (SAGI) }\end{array}$ & .001 \\
\hline $\begin{array}{l}\text { Do not know } \\
\text { parent's } \\
\text { education } \\
\text { level } \\
\text { (SPEL1) }\end{array}$ & -.002 \\
\hline
\end{tabular}




\begin{tabular}{|c|c|}
\hline $\begin{array}{l}\text { Did not } \\
\text { complete } \\
\text { high school } \\
\text { (SPEL2) }\end{array}$ & .001 \\
\hline $\begin{array}{l}\text { High school } \\
\text { diploma or } \\
\text { equivalent } \\
\text { (SPEL3) }\end{array}$ & .005 \\
\hline $\begin{array}{l}\text { Vocational or } \\
\text { technical } \\
\text { training } \\
\text { (SPEL4) } \\
\end{array}$ & -.004 \\
\hline $\begin{array}{l}\text { Less than two } \\
\text { years of } \\
\text { college } \\
\text { (SPEL5) } \\
\end{array}$ & .002 \\
\hline $\begin{array}{l}\text { Associate's } \\
\text { degree } \\
\text { (SPEL6) }\end{array}$ & -.007 \\
\hline $\begin{array}{l}2 \text { or more } \\
\text { years of } \\
\text { college but } \\
\text { no degree } \\
\text { (SPEL7) } \\
\end{array}$ & $\begin{array}{l}-.011 \\
\end{array}$ \\
\hline $\begin{array}{l}\text { Bachelor's } \\
\text { degree } \\
\text { (SPEL8) }\end{array}$ & .006 \\
\hline $\begin{array}{l}\text { Master's } \\
\text { degree or } \\
\text { equivalent } \\
\text { (SPEL9) }\end{array}$ & .005 \\
\hline $\begin{array}{l}\text { First- } \\
\text { professional } \\
\text { degree } \\
\text { (SPEL10) }\end{array}$ & $\begin{array}{l}.008 \\
\end{array}$ \\
\hline $\begin{array}{l}\text { Grade point } \\
\text { average } \\
\text { (SGPA) } \\
\end{array}$ & -.004 \\
\hline $\begin{array}{l}\text { Attend } \\
\text { institution in } \\
\text { state of legal } \\
\text { residence } \\
=\text { Yes (LOC1) }\end{array}$ & -.038 \\
\hline
\end{tabular}




\begin{tabular}{|l|c|}
\hline $\begin{array}{l}\text { Attend } \\
\text { institution in } \\
\text { state of legal } \\
\text { residence=No } \\
\text { (LOC2) }\end{array}$ & .044 \\
\hline $\begin{array}{l}\text { Undeclared } \\
\text { or not in a } \\
\text { degree } \\
\text { program } \\
\text { (PROGN1) }\end{array}$ & -.042 \\
\hline $\begin{array}{l}\text { Humanities } \\
\text { (PROGN2) }\end{array}$ & \\
\hline $\begin{array}{l}\text { Social/ } \\
\text { behavioral } \\
\text { sciences } \\
\text { (PROGN3) } \\
\text { Life sciences } \\
\text { (PROGN4) }\end{array}$ & -.039 \\
\hline $\begin{array}{l}\text { Physical } \\
\text { sciences } \\
\text { (PROGN5) }\end{array}$ & -.041 \\
\hline $\begin{array}{l}\text { Math } \\
\text { (PROGN6) }\end{array}$ & -.031 \\
\hline $\begin{array}{l}\text { Computer/ } \\
\text { information } \\
\text { science } \\
\text { (PROGN7) }\end{array}$ & -.012 \\
\hline $\begin{array}{l}\text { Engineering } \\
\text { (PROGN8) }\end{array}$ \\
\hline $\begin{array}{l}\text { Education } \\
\text { (PROGN9) }\end{array}$ \\
\hline $\begin{array}{l}\text { Business/ } \\
\text { management } \\
\text { (PROGN10) }\end{array}$ \\
\hline $\begin{array}{l}\text { Health } \\
\text { (PROGN11) }\end{array}$ \\
\hline $\begin{array}{l}\text { Vocational/ } \\
\text { technical } \\
\text { (PROGN12) }\end{array}$ \\
\hline
\end{tabular}

Significant relationships were identified between the amount of state need-based financial grant aid paid per student by public institutions and tuition and fees, students' ages, and adjusted 
gross income. In addition relationships were noted between the dependent variable and the education levels of parents who did not complete high school; received a high school diploma or equivalent; received vocational or technical training; had less than two years of college; held Associate's degrees; had two years of college but no degree; and received Bachelor's degrees. Significant relationships were also noted between the independent variable and student's statuses as majors in humanities, physical sciences, engineering and health. These relationships are represented by the following econometric equation:

SFPBM $=-.005 \mathrm{~T}-9.322 \mathrm{SA}+0.00 \mathrm{SAGI}-72.46 \mathrm{SPEL} 1-58.038 \mathrm{SPEL} 2-76.771 \mathrm{SPEL} 3-$ 75.45SPEL4 - 89.936SPEL5 - 77.509SPEL6 - 69.251SPEL8 - 818 SGPA + 124.051LOC1 29.544PROGN2 +81.345PROGN5 + 61.614PROGN8 + 79.395PROGN11 +34.507

Research Question 6b: Is there a relationship between the amount of state merit-based financial grant aid received at private institutions, the amount of tuition and the fees per student charged to in -state students, student characteristics, and academic programs? Research Question $6 \mathrm{~b}$ relates to Hypothesis $\left(\mathrm{H}_{6 \mathrm{~b}}\right)$, that there is no significant relationship between the amount of merit-based state financial grant aid received per student at public institutions, the amount of tuition and the fees per student charged to in-state students, student characteristics, and academic programs. As described in Chapter 3, Equation $6 \mathrm{~b}$ relates to Research Question 6b and Hypothesis 6b:

$$
\mathrm{SFPVM}_{\mathrm{i}}=\mathrm{T}_{\mathrm{i}}+\mathrm{SA}_{\mathrm{i}}+\mathrm{SAGI}_{\mathrm{i}}+\mathrm{SR}_{\mathrm{i}}+\mathrm{SG}_{\mathrm{i}}+\mathrm{SPEL}_{\mathrm{i}}+\mathrm{SGPA}_{\mathrm{i}}+\mathrm{SVA}_{\mathrm{i}}+\mathrm{LOC}_{\mathrm{i}}+\mathrm{PROGN}_{\mathrm{i}}
$$

The significance scores for this equation are displayed in Table 72. The NCES' DAS was used to perform a weighted least squares computation using NPSAS: 04 data. 
Table 72: Equation 6b hypothesis testing results

\begin{tabular}{|l|r|r|r|r|r|}
\hline & Wald $F$ & $\begin{array}{l}\text { Num. } \\
\text { DF }\end{array}$ & $\begin{array}{l}\text { Denom. } \\
\text { DF }\end{array}$ & Commonality & $\begin{array}{l}\text { Probability } \\
F\end{array}$ \\
\hline Overall Fit & 2.225 & 35 & 30 & & .014 \\
\hline Tuition and fees (T) & .162 & 1 & 64 & .000 & .689 \\
\hline Age (SA) & 23.837 & 1 & 64 & .008 & .001 \\
\hline $\begin{array}{l}\text { Adjusted Gross Income } \\
\text { (SAGI) }\end{array}$ & 3.552 & 1 & 64 & .001 & .064 \\
\hline Race (SR) & 1.480 & 5 & 60 & .002 & .210 \\
\hline Gender (SG) & .211 & 1 & 64 & .000 & .648 \\
\hline $\begin{array}{l}\text { Parent's highest education } \\
\text { level (SPEL) }\end{array}$ & .452 & 10 & 55 & .000 & .913 \\
\hline $\begin{array}{l}\text { Grade point average } \\
\text { (SGPA) }\end{array}$ & 7.346 & 1 & 64 & .002 & .009 \\
\hline $\begin{array}{l}\text { Attend institution in state of } \\
\text { legal residence (LOC) }\end{array}$ & 9.778 & 2 & 63 & .017 & .001 \\
\hline Veteran status (SVA) & .000 & 1 & 64 & .000 & .992 \\
\hline Program (PROGN) & 1.456 & 12 & 53 & .007 & .171 \\
\hline
\end{tabular}

The variables Gender (SG) Tuition and fees (T), Race (SR), Gender (SG), Parent's education level (SPEL) and Veteran status (VA) were not significant. Because they were not significant, a second computation was completed without these variables. The significance scores for this computation are displayed in Table 73. All the variables in this equation were significant. The regression coefficients are displayed in Table 74. Only the coefficient for the variable Attend institution in state of legal residence- no was not significant. The coefficient of determination was .0259. From this statistic, we may conclude that 2.6 percent of the variance in state merit-based financial grant aid per student paid by private institutions is explained by the independent variables in this equation.

Table 73: Equation 6b hypothesis testing results second calculation

\begin{tabular}{|l|r|r|r|r|r|}
\hline & Wald $F$ & Num. DF & $\begin{array}{l}\text { Denom. } \\
\text { DF }\end{array}$ & Commonality & \multicolumn{2}{|l|}{$\begin{array}{l}\text { Probability } \\
F\end{array}$} \\
\hline Overall Fit & 5.807 & 4 & 61 & & .001 \\
\hline Age (SA) & 20.194 & 1 & 64 & .014 & .001 \\
\hline $\begin{array}{l}\text { Grade point average } \\
\text { (SGPA) }\end{array}$ & 7.552 & 1 & 64 & .003 & .008 \\
\hline
\end{tabular}




\begin{tabular}{|l|l|l|l|l|l|}
\hline $\begin{array}{l}\text { Attend institution in } \\
\text { state of legal residence } \\
\text { (LOC) }\end{array}$ & 10.487 & 2 & 63 & .016 & .001 \\
\hline
\end{tabular}

Table 74: Equation 6b estimated full sample regression coefficients

\begin{tabular}{|l|r|r|r|r|}
\hline & \multicolumn{1}{|l|}{ B } & \multicolumn{1}{|l|}{ s.e. } & \multicolumn{1}{l|}{ t } & Probability $t$ \\
\hline Intercept & 30.013 & 23.301 & 1.288 & .202 \\
\hline Age (SA) & -6.131 & 1.364 & -4.494 & .001 \\
\hline Grade point average (SGPA) & 0.349 & .127 & 2.748 & .008 \\
\hline $\begin{array}{l}\text { Attend institution in state of legal } \\
\text { residence }\end{array}$ & & & & \\
\hline Yes (LOC1) & 121.836 & 26.520 & 4.594 & .001 \\
\hline No (LOC2) & -1.457 & 4.366 & -0.334 & .740 \\
\hline vs. Foreign or international student & & & & \\
\hline
\end{tabular}

The correlations for this equation are displayed in Table 75.

Table 75: Equation 6b correlations

\begin{tabular}{|c|c|c|c|c|c|}
\hline & $\begin{array}{l}\text { State } \\
\text { merit- } \\
\text { only } \\
\text { grants }\end{array}$ & $\begin{array}{l}\text { Age as of } \\
12 / 31 / 03\end{array}$ & $\begin{array}{l}\text { Grade } \\
\text { point } \\
\text { average }\end{array}$ & $\begin{array}{l}\text { Attend } \\
\text { institution in } \\
\text { state of legal } \\
\text { residence=Yes }\end{array}$ & $\begin{array}{l}\text { Attend } \\
\text { institution in } \\
\text { state of legal } \\
\text { residence=No }\end{array}$ \\
\hline & & & & & \\
\hline $\begin{array}{l}\text { State merit-only } \\
\text { grants (SFPVM) }\end{array}$ & 1 & -.085 & .033 & .105 & -.100 \\
\hline Age (SA) & -.085 & 1 & .158 & .218 & -.208 \\
\hline $\begin{array}{l}\text { Grade point } \\
\text { average (SGPA) }\end{array}$ & .033 & .158 & 1 & .003 & -.002 \\
\hline $\begin{array}{l}\text { Attend } \\
\text { institution in } \\
\text { state of legal } \\
\text { residence=Yes } \\
\text { (LOC1) }\end{array}$ & .105 & .218 & .003 & 1 & -.947 \\
\hline
\end{tabular}




\begin{tabular}{|l|l|l|l|l|l|}
\hline Attend & -.100 & -.208 & -.002 & -.947 & \\
institution in \\
state of legal \\
residence=No \\
(LOC2)
\end{tabular}

The results show that a significant relationship exists between the amount of institutional need-based financial grant aid paid per student by public institutions and students' ages, grade point averages, their statuses as residents in the state within which the institutions are located. These relationships are represented by the following econometric equation:

$$
\mathrm{SFPVM}_{\mathrm{i}}=+-6.131 \mathrm{SA}_{\mathrm{i}}+0.349 \mathrm{SGPA}_{\mathrm{i}}+121.836 \mathrm{LOC} 1+30.013
$$

\section{Research Question 6c: Does the amount of state merit-based financial grant aid} received by students at public institutions differ significantly from the amount of state meritbased financial grant aid receive by students at private institutions? Research Question 6c relates to Hypothesis $\left(\mathrm{H}_{6 \mathrm{c}}\right)$ was that the amount of state merit-based financial grant aid per student received at public institutions was less than or equal to the amount of state merit-based grant aid per student received at private institutions.

As described in Chapter 3, Equation 6c relates to Research Question 6c and Hypothesis $6 \mathrm{c}:$

\section{$\mathrm{SFPBM} \leq \mathrm{SFPVM}$}

The data used for the means comparison are displayed in Table 76. The following formula was used to calculate the $t$ value:

$$
t_{d f}=\frac{\left|\bar{X}_{A}-\bar{x}_{B}\right|}{\sqrt{\hat{V}_{A}+\hat{V}_{B}}}
$$


The means for the two groups that were compared are represented by $\bar{x}_{A}$ and $\bar{x}_{B}$. The respective squared standard errors associated with the means are represented by $\hat{V}_{A}$ and $\hat{V}_{B}$.

The $t$ value for the comparison of the two means was .46. Because the test statistic does not exceed the critical value of \pm 1.96 , the difference between the two means is not statistically significant.

Table 76: Equation 6c group statistics

\begin{tabular}{|l|r|r|}
\hline & \multicolumn{1}{|c|}{ Mean } & Standard Error \\
\hline Public Institutions & 64.595 & 2.343 \\
\hline Private Institutions & 58.817 & 12.434 \\
\hline
\end{tabular}

\section{Research Question 6d: Is there a relationship between the amount of state need-based} financial grant aid received at public institutions, the amount of tuition and the fees per student charged to in-state students, and student characteristics and academic programs? Research Question 6d relates to Hypothesis $\left(\mathrm{H}_{6 \mathrm{~d}}\right)$, that there is no significant relationship between the amount of state need-based financial grant aid received per student at public institutions, the amount of tuition and fees per student charged to in-state students, and student characteristics and academic programs. As described in Chapter 3, Equation 6d relates to Research Question 6d and Hypothesis 6d:

$$
\mathrm{SFPBN}_{\mathrm{i}}=\mathrm{T}_{\mathrm{i}}+\mathrm{SA}_{\mathrm{i}}+\mathrm{SAGI}_{\mathrm{i}}+\mathrm{SR}_{\mathrm{i}}+\mathrm{SG}_{\mathrm{i}}+\mathrm{SPEL}_{\mathrm{i}}+\mathrm{SGPA}_{\mathrm{i}}+\mathrm{SVA}_{\mathrm{i}}+\mathrm{LOC}_{\mathrm{i}}+\mathrm{PROGN}_{\mathrm{i}}
$$

The significance scores for this equation are displayed in Table 77. The NCES' DAS was used to perform a weighted least squares computation using NPSAS: 04 data.

Table 77: Equation 6d hypothesis testing results

\begin{tabular}{|l|r|r|r|r|r|}
\hline & \multicolumn{1}{|l|}{ Wald $F$} & $\begin{array}{l}\text { Num. } \\
\text { DF }\end{array}$ & $\begin{array}{l}\text { Denom. } \\
\text { DF }\end{array}$ & Commonality & \multicolumn{2}{l|}{$\begin{array}{l}\text { Probabilit } \\
\text { y } F\end{array}$} \\
\hline Overall Fit & 22.149 & 35 & 30 & & .001 \\
\hline $\begin{array}{l}\text { Tuition and fees } \\
\text { (SFPBN) }\end{array}$ & 142.202 & 1 & 64 & .017 & .001 \\
\hline Age (SA) & 165.390 & 1 & 64 & .010 & .001 \\
\hline Adjusted Gross Income & 353.520 & 1 & 64 & .030 & .001 \\
\hline
\end{tabular}




\begin{tabular}{|l|r|r|r|r|r|}
\hline (SAGI) & & & & & \\
\hline Race-ethnicity (SR) & 21.349 & 5 & 60 & .014 & .001 \\
\hline Gender (SG) & 8.719 & 1 & 64 & .001 & .004 \\
\hline $\begin{array}{l}\text { Parent's highest } \\
\text { education level (SPEL) }\end{array}$ & 9.985 & 10 & 55 & .008 & .001 \\
\hline $\begin{array}{l}\text { Grade point average } \\
\text { (SGPA) }\end{array}$ & 30.129 & 1 & 64 & .001 & .001 \\
\hline $\begin{array}{l}\text { Attend institution in } \\
\text { state of legal residence } \\
\text { (LOC) }\end{array}$ & 213.808 & 2 & 63 & .026 & .001 \\
\hline Veteran status (SVA) & 9.288 & 1 & 64 & .000 & .003 \\
\hline Program (PROGN) & 2.081 & 12 & 53 & .001 & .034 \\
\hline
\end{tabular}

All the variables in this equation were significant. The coefficient of determination was .1061. From this statistic, we may conclude that 10.61 percent of the variance in state need-based financial grant aid per student paid by public institutions is explained by the independent variables in this equation. The regression coefficients from this equation are displayed in Table 78. The coefficients for the variables White, Other, Vocational or technical training, 2 or more years of college but no degree, Bachelor's degree, Master's degree or equivalent, First professional degree, and all programs were not significant.

Table 78: Equation 6d estimated full sample regression coefficients

\begin{tabular}{|l|r|r|r|r|}
\hline & \multicolumn{1}{l|}{ B } & \multicolumn{1}{l|}{ s.e. } & \multicolumn{1}{l|}{ Probability $t$} \\
\hline Intercept & -419.41 & 90.562 & -4.631 & .001 \\
\hline Tuition and fees (SFPBN) & .048 & .004 & 11.925 & .001 \\
\hline Age (SA) & -14.493 & 1.127 & -12.860 & .001 \\
\hline Adjusted Gross Income (SAGI) & -.004 & .000 & -18.802 & .001 \\
\hline Race (SR) & & & & .844 \\
\hline White (R1) & -9.793 & 49.439 & -.198 & .036 \\
\hline Black or African American (R2) & 129.25 & 60.353 & 2.142 & .001 \\
\hline Hispanic or Latino (R3) & 272.262 & 64.239 & 4.238 & .001 \\
\hline Asian (R4) & 370.556 & 73.210 & 5.062 & .134 \\
\hline Other (R5) & 80.047 & 52.790 & 1.516 & \\
\hline vs. More than one race & & & & .004 \\
\hline Gender & & & & \\
\hline Male (SG) & -48.785 & 16.522 & -2.953 & \\
\hline vs. Female & & & & \\
\hline Parent's highest education level & & & & \\
\hline
\end{tabular}




\begin{tabular}{|c|c|c|c|c|}
\hline $\begin{array}{l}\text { Do not know parent's education level } \\
\text { (SPEL1) }\end{array}$ & 289.779 & 87.645 & 3.306 & .002 \\
\hline Did not complete high school (SPEL2) & 315.485 & 65.735 & 4.799 & .001 \\
\hline $\begin{array}{l}\text { High school diploma or equivalent } \\
\text { (SPEL3) }\end{array}$ & 135.13 & 40.645 & 3.325 & .001 \\
\hline $\begin{array}{l}\text { Vocational or technical training } \\
\text { (SPEL4) }\end{array}$ & 84.293 & 50.326 & 1.675 & .099 \\
\hline $\begin{array}{l}\text { Less than two years of college } \\
\text { (SPEL5) }\end{array}$ & 118.693 & 44.447 & 2.670 & .010 \\
\hline Associate's degree (SPEL6) & 122.408 & 40.893 & 2.993 & .004 \\
\hline $\begin{array}{l}2 \text { or more years of college but no } \\
\text { degree (SPEL7) }\end{array}$ & 42.254 & 48.693 & .868 & .389 \\
\hline Bachelor's degree (SPEL8) & 2.838 & 40.200 & .071 & .944 \\
\hline Master's degree or equivalent (SPEL9) & -37.767 & 39.038 & -.967 & .337 \\
\hline First-professional degree (SPEL10) & -47.042 & 66.269 & -.710 & .480 \\
\hline \multicolumn{5}{|l|}{ vs. Doctoral degree or equivalent } \\
\hline Grade point average (SGPA) & .461 & .084 & 5.489 & .001 \\
\hline \multicolumn{5}{|l|}{$\begin{array}{l}\text { Attend institution in state of legal } \\
\text { residence }\end{array}$} \\
\hline Yes (LOC1) & 780.666 & 44.831 & 17.414 & .001 \\
\hline No (LOC2) & 212.236 & 32.886 & 6.454 & .001 \\
\hline \multicolumn{5}{|l|}{ vs. Foreign or international student } \\
\hline \multicolumn{5}{|l|}{ Veteran status } \\
\hline Not a veteran (SVA) & 105.190 & 34.515 & 3.048 & .003 \\
\hline \multicolumn{5}{|l|}{ vs. Veteran } \\
\hline \multicolumn{5}{|l|}{ Program } \\
\hline $\begin{array}{l}\text { Undeclared or not in a degree program } \\
\text { (PROGN1) }\end{array}$ & 15.372 & 26.734 & .575 & .567 \\
\hline Humanities (PROGN2) & 40.769 & 28.921 & 1.410 & .163 \\
\hline Social/behavioral sciences (PROGN3) & 63.020 & 37.692 & 1.672 & .099 \\
\hline Life sciences (PROGN4) & 25.808 & 36.844 & .700 & .486 \\
\hline Physical sciences (PROGN5) & -66.316 & 55.114 & -1.203 & .233 \\
\hline Math (PROGN6) & 86.914 & 110.071 & .790 & .433 \\
\hline $\begin{array}{l}\text { Computer/information science } \\
\text { (PROGN7) }\end{array}$ & -8.149 & 41.808 & -.195 & .846 \\
\hline Engineering (PROGN8) & 56.766 & 44.004 & 1.290 & .202 \\
\hline Education (PROGN9) & 1.145 & 36.320 & .032 & .975 \\
\hline Business/management (PROGN10) & -39.372 & 26.084 & -1.509 & .136 \\
\hline Health (PROGN11) & -26.973 & 33.050 & -.816 & .417 \\
\hline Vocational/technical (PROGN12) & 83.951 & 59.752 & 1.405 & .165 \\
\hline vs. Other technical/professional & & & & \\
\hline
\end{tabular}

The correlations for this equation are displayed in Table 79. 
Table 79: Equation 6d correlations

\begin{tabular}{|c|c|c|c|c|c|c|}
\hline & $\begin{array}{l}\text { State - } \\
\text { need-based } \\
\text { grants }\end{array}$ & $\begin{array}{l}\text { Tuition } \\
\text { and fees }\end{array}$ & Age & $\begin{array}{l}\text { Adjusted Gross } \\
\text { Income (AGI) }\end{array}$ & White & $\begin{array}{l}\text { Black or } \\
\text { African } \\
\text { American }\end{array}$ \\
\hline $\begin{array}{l}\text { State-need-based } \\
\text { grants (SFPBN) }\end{array}$ & 1 & .049 & -.080 & -.189 & -.133 & .042 \\
\hline $\begin{array}{l}\text { Tuition and fees } \\
\text { (T) }\end{array}$ & .049 & 1 & -.263 & .163 & .020 & .006 \\
\hline Age (SA) & -.080 & -.263 & 1 & -.181 & -.038 & .067 \\
\hline $\begin{array}{l}\text { Adjusted Gross } \\
\text { Income (SAGI) }\end{array}$ & -.189 & .163 & -.181 & 1 & .171 & -.132 \\
\hline White (R1) & -.133 & .020 & -.038 & .171 & 1 & -.532 \\
\hline $\begin{array}{l}\text { Black or African } \\
\text { American (R2) }\end{array}$ & .042 & .006 & .067 & -.132 & -.532 & 1 \\
\hline $\begin{array}{l}\text { Hispanic or } \\
\text { Latino (R3) }\end{array}$ & .094 & -.076 & .001 & -.082 & -.463 & -.102 \\
\hline Asian (R4) & .095 & .063 & -.036 & -.044 & -.392 & -.086 \\
\hline Other (R5) & .004 & -.030 & .032 & -.030 & -.256 & -.057 \\
\hline Male (SG) & -.039 & .041 & -.052 & .039 & .028 & -.034 \\
\hline $\begin{array}{l}\text { Do not know } \\
\text { parent's } \\
\text { education level } \\
\text { (SPEL1) }\end{array}$ & .046 & -.013 & .069 & -.065 & -.103 & .036 \\
\hline $\begin{array}{l}\text { Did not complete } \\
\text { high school } \\
\text { (SPEL2) }\end{array}$ & .073 & -.065 & .151 & -.106 & -.163 & .036 \\
\hline $\begin{array}{l}\text { High school } \\
\text { diploma or } \\
\text { equivalent } \\
\text { (SPEL3) }\end{array}$ & .050 & -.083 & .125 & -.154 & -.033 & .053 \\
\hline $\begin{array}{l}\text { Vocational or } \\
\text { technical training } \\
\text { (SPEL4) }\end{array}$ & .003 & -.008 & .026 & -.018 & .009 & .001 \\
\hline $\begin{array}{l}\text { Less than two } \\
\text { years of college } \\
\text { (SPEL5) }\end{array}$ & .028 & -.016 & -.004 & -.044 & -.005 & .016 \\
\hline $\begin{array}{l}\text { Associate's } \\
\text { degree (SPEL6) }\end{array}$ & .020 & -.020 & -.004 & -.020 & -.008 & .021 \\
\hline $\begin{array}{l}2 \text { or more years } \\
\text { of college but no } \\
\text { degree (SPEL7) }\end{array}$ & .002 & -.026 & .011 & -.039 & -.012 & .040 \\
\hline
\end{tabular}




\begin{tabular}{|c|c|c|c|c|c|c|}
\hline $\begin{array}{l}\text { Bachelor's degree } \\
\text { (SPEL8) }\end{array}$ & -.051 & .0380 & -.100 & .096 & .067 & -.053 \\
\hline $\begin{array}{l}\text { Master's degree } \\
\text { or equivalent } \\
\text { (SPEL9) }\end{array}$ & -.061 & .077 & -.098 & .125 & .067 & -.048 \\
\hline $\begin{array}{l}\text { First-professional } \\
\text { degree (SPEL10) }\end{array}$ & -.022 & .041 & -.033 & .058 & .015 & -.012 \\
\hline $\begin{array}{l}\text { Grade point } \\
\text { average (SGPA) }\end{array}$ & .004 & .063 & .133 & .048 & .121 & -.132 \\
\hline $\begin{array}{l}\text { Attend institution } \\
\text { in state of legal } \\
\text { residence=Yes } \\
\text { (LOC1) }\end{array}$ & .106 & -.559 & .095 & -.076 & .028 & -.039 \\
\hline $\begin{array}{l}\text { Attend institution } \\
\text { in state of legal } \\
\text { residence=No } \\
\text { (LOC2) }\end{array}$ & -.096 & .524 & -.097 & .100 & .025 & .033 \\
\hline $\begin{array}{l}\text { Veteran } \\
\text { status=Not a } \\
\text { veteran }(\mathrm{SVA})\end{array}$ & .028 & .056 & -.202 & .056 & .011 & -.021 \\
\hline $\begin{array}{l}\text { Undeclared or } \\
\text { not in a degree } \\
\text { program } \\
\text { (PROGN1) }\end{array}$ & -.012 & -.078 & .001 & .010 & -.002 & -.034 \\
\hline $\begin{array}{l}\text { Humanities } \\
\text { (PROGN2) }\end{array}$ & .007 & -.002 & .008 & -.008 & .017 & -.038 \\
\hline $\begin{array}{l}\text { Social/behavioral } \\
\text { sciences } \\
\text { (PROGN3) }\end{array}$ & .032 & .020 & -.017 & -.011 & -.012 & .011 \\
\hline $\begin{array}{l}\text { Life sciences } \\
\text { (PROGN4) }\end{array}$ & .012 & .046 & -.047 & .002 & -.004 & -.009 \\
\hline $\begin{array}{l}\text { Physical sciences } \\
\text { (PROGN5) }\end{array}$ & -.008 & .013 & -.004 & -.004 & .003 & -.009 \\
\hline Math (PROGN6) & .013 & .014 & -.004 & -.001 & -.011 & -.012 \\
\hline $\begin{array}{l}\text { Computer/ } \\
\text { information } \\
\text { science } \\
\text { (PROGN7) } \\
\end{array}$ & -.011 & -.010 & .018 & -.006 & -.025 & .023 \\
\hline $\begin{array}{l}\text { Engineering } \\
\text { (PROGN8) }\end{array}$ & .007 & .083 & -.041 & .031 & -.008 & .002 \\
\hline $\begin{array}{l}\text { Education } \\
\text { (PROGN9) }\end{array}$ & .005 & -.016 & .023 & -.014 & .056 & -.023 \\
\hline $\begin{array}{l}\text { Business/ } \\
\text { management } \\
\text { (PROGN10) }\end{array}$ & -.025 & -.007 & .016 & .005 & -.033 & .040 \\
\hline
\end{tabular}




\begin{tabular}{|l|r|r|r|r|r|r|}
\hline $\begin{array}{l}\text { Health } \\
\text { (PROGN11) }\end{array}$ & -.006 & -.033 & .038 & -.019 & .010 & .003 \\
\hline $\begin{array}{l}\text { Vocational/ } \\
\text { technical } \\
\text { (PROGN12) }\end{array}$ & -.002 & .013 & .012 & .001 & .022 & -.025 \\
\hline
\end{tabular}

Table 79: Equation 6d correlations (continued)

\begin{tabular}{|c|c|c|c|c|c|c|}
\hline & $\begin{array}{l}\text { Hispanic } \\
\text { or Latino }\end{array}$ & Asian & Other & Male & $\begin{array}{l}\text { Do not } \\
\text { know } \\
\text { parent's } \\
\text { education } \\
\text { level }\end{array}$ & $\begin{array}{l}\text { Did not } \\
\text { complete } \\
\text { high school }\end{array}$ \\
\hline $\begin{array}{l}\text { State-need-based } \\
\text { grants (SFPBN) }\end{array}$ & .094 & .095 & .004 & -.039 & .046 & .073 \\
\hline $\begin{array}{l}\text { Tuition and fees } \\
\text { (T) }\end{array}$ & -.076 & .063 & -0.030 & .041 & -.013 & -.065 \\
\hline Age (SA) & .001 & -.036 & .032 & -.052 & .069 & .151 \\
\hline $\begin{array}{l}\text { Adjusted Gross } \\
\text { Income (SAGI) }\end{array}$ & -.082 & -.044 & -.030 & .039 & -.065 & -.106 \\
\hline White (R1) & -.463 & -.392 & -.256 & .028 & -.103 & -.163 \\
\hline $\begin{array}{l}\text { Black or African } \\
\text { American (R2) }\end{array}$ & -.102 & -.086 & -.057 & -.034 & .036 & .036 \\
\hline $\begin{array}{l}\text { Hispanic or } \\
\text { Latino (R3) }\end{array}$ & 1 & -.075 & -.049 & -.026 & .040 & .181 \\
\hline Asian (R4) & -.075 & 1 & -.042 & .022 & .085 & .055 \\
\hline Other (R5) & -.049 & -.042 & 1 & .006 & .026 & .023 \\
\hline Male (SG) & -.026 & .022 & .006 & 1 & .001 & -.042 \\
\hline $\begin{array}{l}\text { Do not know } \\
\text { parent's } \\
\text { education level } \\
\text { (SPEL1) }\end{array}$ & .040 & .085 & .026 & .001 & 1 & -.026 \\
\hline $\begin{array}{l}\text { Did not complete } \\
\text { high school } \\
\text { (SPEL2) }\end{array}$ & .181 & .055 & .023 & -.042 & -.026 & 1 \\
\hline $\begin{array}{l}\text { High school } \\
\text { diploma or } \\
\text { equivalent } \\
\text { (SPEL3) }\end{array}$ & .025 & -.015 & -.009 & -.029 & -.069 & -.107 \\
\hline $\begin{array}{l}\text { Vocational or } \\
\text { technical training } \\
\text { (SPEL4) }\end{array}$ & .004 & -.014 & -.014 & -.027 & -.025 & $\begin{array}{l}-.040 \\
\end{array}$ \\
\hline $\begin{array}{l}\text { Less than two } \\
\text { years of college } \\
\text { (SPEL5) }\end{array}$ & .015 & -.023 & -.008 & -.027 & -.035 & -.054 \\
\hline
\end{tabular}




\begin{tabular}{|l|c|c|c|c|c|c|}
\hline $\begin{array}{l}\text { Associate's } \\
\text { degree (SPEL6) }\end{array}$ & -.011 & -.005 & -.009 & -.008 & -.037 & -.056 \\
\hline $\begin{array}{l}\text { 2 or more years } \\
\text { of college but no } \\
\text { degree (SPEL7) }\end{array}$ & -.003 & -.019 & -.021 & -.020 & -.028 & -.044 \\
\hline $\begin{array}{l}\text { Bachelor's degree } \\
\text { (SPEL8) }\end{array}$ & -.055 & -.009 & .006 & .045 & -.077 & -.118 \\
\hline $\begin{array}{l}\text { Master's degree } \\
\text { or equivalent } \\
\text { (SPEL9) }\end{array}$ & -.050 & -.009 & .009 & .028 & -.059 & -.090 \\
\hline $\begin{array}{l}\text { First-professional } \\
\text { degree (SPEL10) }\end{array}$ & -.015 & .011 & .001 & -.002 & -.021 & -.032 \\
\hline $\begin{array}{l}\text { Grade point } \\
\text { average (SGPA) }\end{array}$ & -.054 & .016 & -.009 & -.140 & -.027 & -.004 \\
\hline $\begin{array}{l}\text { Attend institution } \\
\text { in state of legal } \\
\text { residence=Yes } \\
\text { (LOC1) }\end{array}$ & .043 & -.064 & .014 & -.031 & .010 & .032 \\
\hline $\begin{array}{l}\text { Attend institution } \\
\text { in state of legal } \\
\text { residence=No } \\
\text { (LOC2) }\end{array}$ & -.048 & -.020 & -.021 & .025 & -.019 & -.040 \\
\hline $\begin{array}{l}\text { Veteran } \\
\text { status=Not a } \\
\text { veteran (SVA) }\end{array}$ & .007 & .012 & -.021 & -.097 & -.038 & -.014 \\
\hline $\begin{array}{l}\text { Undeclared or } \\
\text { not in a degree } \\
\text { program } \\
\text { (PROGN1) }\end{array}$ & .010 & .013 & .028 & .004 & -.002 & .009 \\
\hline $\begin{array}{l}\text { Humanities } \\
\text { (PROGN2) }\end{array}$ & .016 & -.026 & .008 & -.022 & .006 & -.011 \\
\hline $\begin{array}{l}\text { Social/behavioral } \\
\text { sciences } \\
\text { (PROGN3) }\end{array}$ & .009 & .002 & -.009 & -.051 & -.003 & -.003 \\
\hline $\begin{array}{l}\text { Life sciences } \\
\text { (PROGN4) }\end{array}$ & -.005 & .023 & .005 & .008 & -.015 & -.021 \\
\hline $\begin{array}{l}\text { Physical sciences } \\
\text { (PROGN5) }\end{array}$ & -.008 & .006 & -.005 & .025 & .011 & -.015 \\
\hline Math (PROGN6) & .015 & .028 & -.011 & .016 & -.002 & .012 \\
\hline $\begin{array}{l}\text { Computer/ } \\
\text { information } \\
\text { science } \\
\text { (PROGN7) }\end{array}$ & -.022 & .047 & .001 & .148 & .010 & -.010 \\
\hline $\begin{array}{l}\text { Engineering } \\
\text { (PROGN8) }\end{array}$ & -.013 & -.026 & -.006 & .198 & -.013 & -.011 \\
\hline
\end{tabular}




\begin{tabular}{|l|r|r|r|r|r|r|}
\hline $\begin{array}{l}\text { Education } \\
\text { (PROGN9) }\end{array}$ & .001 & -.060 & -.020 & -.157 & .001 & .007 \\
\hline $\begin{array}{l}\text { Business/ } \\
\text { management } \\
\text { (PROGN10) }\end{array}$ & -.010 & .031 & .008 & .053 & .011 & .013 \\
\hline $\begin{array}{l}\text { Health } \\
\text { (PROGN11) }\end{array}$ & -.006 & -.011 & -.001 & -.130 & .003 & .023 \\
\hline $\begin{array}{l}\text { Vocational/ } \\
\text { technical } \\
\text { (PROGN12) }\end{array}$ & -.004 & -.003 & -.003 & .075 & -.002 & .001 \\
\hline
\end{tabular}

Table 79: Equation 6d correlations (continued)

\begin{tabular}{|c|c|c|c|c|c|c|}
\hline & $\begin{array}{l}\text { High } \\
\text { school } \\
\text { diploma } \\
\text { or } \\
\text { equivalent }\end{array}$ & $\begin{array}{l}\text { Vocational } \\
\text { or technical } \\
\text { training }\end{array}$ & $\begin{array}{l}\text { Less } \\
\text { than two } \\
\text { years of } \\
\text { college }\end{array}$ & $\begin{array}{l}\text { Associate's } \\
\text { degree }\end{array}$ & $\begin{array}{l}2 \text { or } \\
\text { more } \\
\text { years of } \\
\text { college } \\
\text { but no } \\
\text { degree }\end{array}$ & $\begin{array}{l}\text { Bachelor's } \\
\text { degree }\end{array}$ \\
\hline $\begin{array}{l}\text { State-need- } \\
\text { based grants } \\
\text { (SFPBN) }\end{array}$ & .050 & .003 & .028 & .020 & .002 & -.051 \\
\hline $\begin{array}{l}\text { Tuition and } \\
\text { fees (T) }\end{array}$ & -.083 & -.008 & -.016 & -.020 & -.026 & .038 \\
\hline Age (SA) & .125 & .026 & -.004 & -.004 & .011 & -.100 \\
\hline $\begin{array}{l}\text { Adjusted } \\
\text { Gross Income } \\
\text { (SAGI) }\end{array}$ & -.154 & -.018 & -.044 & -.020 & -.039 & .096 \\
\hline White (R1) & -.033 & .009 & -.005 & -.008 & -.012 & .068 \\
\hline $\begin{array}{l}\text { Black or } \\
\text { African } \\
\text { American } \\
\text { (R2) }\end{array}$ & .053 & .001 & .016 & .021 & .040 & -.053 \\
\hline $\begin{array}{l}\text { Hispanic or } \\
\text { Latino (R3) }\end{array}$ & .025 & .004 & .015 & -.011 & -.003 & -.055 \\
\hline Asian (R4) & -.015 & -.014 & -.023 & -.005 & -.019 & -.009 \\
\hline Other (R5) & -.009 & -.014 & -.008 & -.009 & -.021 & .006 \\
\hline Male (SG) & -.029 & -.027 & -.027 & -.008 & -.019 & .045 \\
\hline $\begin{array}{l}\text { Do not know } \\
\text { parent's } \\
\text { education } \\
\text { level (SPEL1) }\end{array}$ & -.069 & -.025 & -.035 & -.037 & -.028 & -.077 \\
\hline $\begin{array}{l}\text { Did not } \\
\text { complete high } \\
\text { school }\end{array}$ & -.107 & -.039 & -.054 & -.056 & -.044 & -.118 \\
\hline
\end{tabular}




\begin{tabular}{|c|c|c|c|c|c|c|}
\hline (SPEL2) & & & & & & \\
\hline $\begin{array}{l}\text { High school } \\
\text { diploma or } \\
\text { equivalent } \\
\text { (SPEL3) }\end{array}$ & 1 & -.104 & -.145 & -.150 & -.116 & -.316 \\
\hline $\begin{array}{l}\text { Vocational or } \\
\text { technical } \\
\text { training } \\
\text { (SPEL4) }\end{array}$ & -.104 & 1 & -.053 & -.055 & -.043 & -.116 \\
\hline $\begin{array}{l}\text { Less than two } \\
\text { years of } \\
\text { college } \\
\text { (SPEL5) }\end{array}$ & -.145 & -.053 & 1 & -.077 & -.059 & -.161 \\
\hline $\begin{array}{l}\text { Associate's } \\
\text { degree } \\
\text { (SPEL6) }\end{array}$ & -.150 & -.055 & -.077 & 1 & -.061 & -.167 \\
\hline $\begin{array}{l}2 \text { or more } \\
\text { years of } \\
\text { college but no } \\
\text { degree } \\
\text { (SPEL7) }\end{array}$ & -.116 & -.043 & -.059 & -.061 & 1 & -.129 \\
\hline $\begin{array}{l}\text { Bachelor's } \\
\text { degree } \\
\text { (SPEL8) } \\
\end{array}$ & -.316 & -.116 & -.161 & -.167 & -.129 & 1 \\
\hline $\begin{array}{l}\text { Master's } \\
\text { degree or } \\
\text { equivalent } \\
\text { (SPEL9) }\end{array}$ & -.241 & -.088 & -.123 & -.127 & -.098 & -.267 \\
\hline $\begin{array}{l}\text { First- } \\
\text { professional } \\
\text { degree } \\
\text { (SPEL10) }\end{array}$ & -.086 & -.032 & -.044 & -.046 & -.035 & -.096 \\
\hline $\begin{array}{l}\text { Grade point } \\
\text { average } \\
\text { (SGPA) } \\
\end{array}$ & -.045 & .025 & -.018 & -.008 & -.006 & .005 \\
\hline $\begin{array}{l}\text { Attend } \\
\text { institution in } \\
\text { state of legal } \\
\text { residence=Yes } \\
\text { (LOC1) }\end{array}$ & .040 & .002 & .030 & .016 & .023 & -.030 \\
\hline $\begin{array}{l}\text { Attend } \\
\text { institution in } \\
\text { state of legal } \\
\text { residence=No }\end{array}$ & -.039 & -.011 & -.023 & -.019 & -.017 & .028 \\
\hline
\end{tabular}




\begin{tabular}{|l|r|r|r|r|r|r|}
\hline (LOC2) & & & & & & \\
\hline $\begin{array}{l}\text { Veteran } \\
\text { status=Not a } \\
\text { veteran (SVA) }\end{array}$ & -.039 & -.012 & -.004 & -.009 & .001 & .034 \\
\hline $\begin{array}{l}\text { Undeclared or } \\
\text { not in a degree } \\
\text { program } \\
\text { (PROGN1) }\end{array}$ & .006 & -.001 & -.009 & -.019 & .003 & .003 \\
\hline $\begin{array}{l}\text { Humanities } \\
\text { (PROGN2) }\end{array}$ & -.007 & -.004 & -.008 & -.006 & -.002 & -.007 \\
\hline $\begin{array}{l}\text { Social/ } \\
\text { behavioral } \\
\text { sciences } \\
\text { (PROGN3) }\end{array}$ & -.009 & -.014 & .002 & -.005 & .018 & -.008 \\
\hline $\begin{array}{l}\text { Life sciences } \\
\text { (PROGN4) }\end{array}$ & -.014 & .007 & -.011 & -.013 & -.001 & .017 \\
\hline $\begin{array}{l}\text { Physical } \\
\text { sciences } \\
\text { (PROGN5) }\end{array}$ & -.006 & -.009 & .002 & .003 & -.009 & -.005 \\
\hline $\begin{array}{l}\text { Math } \\
\text { (PROGN6) }\end{array}$ & -.004 & .005 & -.006 & .026 & -.016 & -.001 \\
\hline $\begin{array}{l}\text { Computer/ } \\
\text { information } \\
\text { science } \\
\text { (PROGN7) }\end{array}$ & -.001 & .013 & -.018 & -.006 & -.011 & .013 \\
\hline $\begin{array}{l}\text { Engineering } \\
\text { (PROGN8) }\end{array}$ & -.038 & -.002 & -.006 & -.003 & -.007 & .020 \\
\hline $\begin{array}{l}\text { Education } \\
\text { (PROGN9) }\end{array}$ & .025 & -.008 & .041 & -.007 & .005 & -.014 \\
\hline $\begin{array}{l}\text { Business/ } \\
\text { management } \\
\text { (PROGN10) }\end{array}$ & .001 & -.001 & -.005 & .016 & -.005 & -.001 \\
\hline $\begin{array}{l}\text { Health } \\
\text { (PROGN11) }\end{array}$ & .008 & .021 & .014 & .013 & .006 & -.015 \\
\hline $\begin{array}{l}\text { Vocationa1/ } \\
\text { technical } \\
\text { (PROGN12) }\end{array}$ & .005 & -.004 & .002 & -.007 & -.011 & .006 \\
\hline
\end{tabular}


Table 79: Equation 6d correlations (continued)

\begin{tabular}{|l|c|r|r|r|r|r|}
\hline & $\begin{array}{l}\text { Master's } \\
\text { degree or } \\
\text { equivalent }\end{array}$ & $\begin{array}{l}\text { First- } \\
\text { professional } \\
\text { degree }\end{array}$ & $\begin{array}{l}\text { Grade } \\
\text { point } \\
\text { average }\end{array}$ & $\begin{array}{l}\text { Attend } \\
\text { institution } \\
\text { in state of } \\
\text { legal } \\
\text { residence } \\
\text { =Yes }\end{array}$ & $\begin{array}{l}\text { Attend } \\
\text { institution } \\
\text { in state of } \\
\text { legal } \\
\text { residence } \\
\text { =No }\end{array}$ & $\begin{array}{l}\text { Veteran } \\
\text { status= } \\
\text { Not a } \\
\text { veteran }\end{array}$ \\
\hline $\begin{array}{l}\text { State-need- } \\
\text { based grants } \\
\text { (SFPBN) }\end{array}$ & -.061 & -.022 & .004 & .106 & -.096 & .028 \\
\hline $\begin{array}{l}\text { Tuition and fees } \\
\text { (T) }\end{array}$ & .077 & .041 & .063 & -.559 & .524 & .056 \\
\hline Age (SA) & -.098 & -.033 & .133 & .095 & -.097 & -.202 \\
\hline $\begin{array}{l}\text { Adjusted Gross } \\
\text { Income (SAGI) }\end{array}$ & .125 & .058 & .048 & -.076 & .100 & .056 \\
\hline White (R1) & .067 & .015 & .121 & .028 & .025 & .011 \\
\hline $\begin{array}{l}\text { Black or African } \\
\text { American (R2) }\end{array}$ & -.048 & -.012 & -.132 & -.039 & .033 & -.021 \\
\hline $\begin{array}{l}\text { Hispanic or } \\
\text { Latino (R3) }\end{array}$ & -.050 & -.015 & -.054 & .043 & -.048 & .007 \\
\hline Asian (R4) & -.009 & .011 & .016 & -.064 & -.020 & .012 \\
\hline Other (R5) & .009 & .001 & -.009 & .014 & -.021 & -.021 \\
\hline Male (SG) & .028 & -.002 & -.140 & -.031 & .025 & -.097 \\
\hline $\begin{array}{l}\text { Do not know } \\
\text { parent's } \\
\text { education level } \\
\text { (SPEL1) }\end{array}$ & -.059 & -.021 & -.027 & .010 & -.019 & -.038 \\
\hline $\begin{array}{l}\text { Did not } \\
\text { complete high } \\
\text { school (SPEL2) }\end{array}$ & -.090 & -.032 & -.004 & .032 & -.035 & -.014 \\
\hline $\begin{array}{l}\text { High school } \\
\text { diploma or } \\
\text { equivalent } \\
\text { SPEL3) }\end{array}$ & -.241 & -.086 & -.045 & .040 & -.040 & -.039 \\
\hline $\begin{array}{l}\text { Vocational or } \\
\text { technical } \\
\text { training } \\
\text { (SPEL4) }\end{array}$ & -.088 & -.032 & .025 & .002 & -.011 & -.012 \\
\hline $\begin{array}{l}\text { Less than two } \\
\text { years of college } \\
\text { (SPEL5) }\end{array}$ & -.123 & -.044 & -.018 & .030 & -.023 & -.004 \\
\hline $\begin{array}{l}\text { Associate's } \\
\text { degree (SPEL6) }\end{array}$ & -.127 & -.046 & -.008 & .016 & -.019 & -.009 \\
\hline
\end{tabular}




\begin{tabular}{|c|c|c|c|c|c|c|}
\hline $\begin{array}{l}2 \text { or more years } \\
\text { of college but } \\
\text { no degree } \\
\text { (SPEL7) }\end{array}$ & -.098 & -.035 & -.006 & .023 & -.017 & .001 \\
\hline $\begin{array}{l}\text { Bachelor's } \\
\text { degree (SPEL8) }\end{array}$ & $\begin{array}{l}.267 \\
\end{array}$ & -.096 & .005 & -.030 & .028 & .034 \\
\hline $\begin{array}{l}\text { Master's degree } \\
\text { or equivalent } \\
\text { (SPEL9) }\end{array}$ & 1 & -.0730 & .037 & -.049 & .055 & .030 \\
\hline $\begin{array}{l}\text { First- } \\
\text { professional } \\
\text { degree } \\
\text { (SPEL10) }\end{array}$ & \begin{tabular}{|l|}
-.073 \\
\end{tabular} & 1 & .033 & -.019 & .017 & .002 \\
\hline $\begin{array}{l}\text { Grade point } \\
\text { average (SGPA) }\end{array}$ & .037 & .033 & 1 & -.023 & .008 & -.027 \\
\hline $\begin{array}{l}\text { Attend } \\
\text { institution in } \\
\text { state of legal } \\
\text { residence=Yes } \\
\text { (LOC1) }\end{array}$ & \begin{tabular}{|l|}
-.049 \\
\end{tabular} & -.019 & -.023 & 1 & -.906 & -.027 \\
\hline $\begin{array}{l}\text { Attend } \\
\text { institution in } \\
\text { state of legal } \\
\text { residence=No } \\
\text { (LOC2) }\end{array}$ & .055 & .020 & .008 & -.906 & 1 & .021 \\
\hline $\begin{array}{l}\text { Veteran } \\
\text { status=Not a } \\
\text { veteran (SVA) }\end{array}$ & .030 & .002 & -.030 & -.027 & .021 & 1 \\
\hline $\begin{array}{l}\text { Undeclared or } \\
\text { not in a degree } \\
\text { program } \\
\text { (PROGN1) }\end{array}$ & $\begin{array}{l}.007 \\
\end{array}$ & .016 & -.053 & .015 & -.012 & 0 \\
\hline $\begin{array}{l}\text { Humanities } \\
\text { (PROGN2) }\end{array}$ & .021 & .010 & .023 & -.008 & $\begin{array}{l}.009 \\
\end{array}$ & .003 \\
\hline $\begin{array}{l}\text { Social/ } \\
\text { behavioral } \\
\text { sciences } \\
\text { (PROGN3) }\end{array}$ & $\begin{array}{l}.009 \\
\end{array}$ & .005 & -.008 & .016 & -.011 & .018 \\
\hline $\begin{array}{l}\text { Life sciences } \\
\text { (PROGN4) }\end{array}$ & .011 & .012 & .006 & -.016 & .014 & .012 \\
\hline $\begin{array}{l}\text { Physical } \\
\text { sciences } \\
\text { (PROGN5) }\end{array}$ & .015 & .003 & .014 & $\begin{array}{l}.001 \\
\end{array}$ & .002 & -.010 \\
\hline $\begin{array}{l}\text { Math } \\
\text { (PROGN6) }\end{array}$ & -.007 & -.001 & .002 & -.006 & .001 & .009 \\
\hline
\end{tabular}




\begin{tabular}{|l|r|r|r|r|r|r|}
\hline $\begin{array}{l}\text { Computer/ } \\
\text { information } \\
\text { science } \\
\text { (PROGN7) }\end{array}$ & -.001 & .013 & -.024 & -.004 & -.006 & -.019 \\
\hline $\begin{array}{l}\text { Engineering } \\
\text { (PROGN8) }\end{array}$ & .022 & .013 & -.008 & -.048 & .041 & -.010 \\
\hline $\begin{array}{l}\text { Education } \\
\text { (PROGN9) }\end{array}$ & -.016 & -.011 & .066 & .041 & -.033 & .017 \\
\hline $\begin{array}{l}\text { Business/ } \\
\text { management } \\
\text { (PROGN10) }\end{array}$ & -.003 & -.033 & -.026 & -.006 & -.011 & -.002 \\
\hline $\begin{array}{l}\text { Health } \\
\text { (PROGN11) }\end{array}$ & -.026 & -.007 & .046 & .023 & -.014 & -.007 \\
\hline $\begin{array}{l}\text { Vocational/ } \\
\text { technical } \\
\text { (PROGN12) }\end{array}$ & .005 & -.008 & -.004 & -.038 & .044 & -.008 \\
\hline
\end{tabular}

Table 79: Equation 6d correlations (continued)

\begin{tabular}{|l|r|r|r|r|r|r|}
\hline & $\begin{array}{l}\text { Undeclared } \\
\text { or not in a } \\
\text { degree } \\
\text { program }\end{array}$ & Humanities & $\begin{array}{l}\text { Social/ } \\
\text { behavioral } \\
\text { sciences }\end{array}$ & $\begin{array}{l}\text { Life } \\
\text { sciences }\end{array}$ & $\begin{array}{l}\text { Physical } \\
\text { sciences }\end{array}$ & Math \\
\hline $\begin{array}{l}\text { State-need-based } \\
\text { grants (SFPBN) }\end{array}$ & -.012 & .007 & .032 & .012 & -.008 & .013 \\
\hline $\begin{array}{l}\text { Tuition and fees } \\
\text { (T) }\end{array}$ & -.078 & -.002 & .020 & .046 & .013 & .014 \\
\hline Age (SA) & .001 & .008 & -.017 & -.047 & -.004 & -.004 \\
\hline $\begin{array}{l}\text { Adjusted Gross } \\
\text { Income (SAGI) }\end{array}$ & .010 & -.008 & -.011 & .002 & -.004 & -.001 \\
\hline White (R1) & -.002 & .017 & -.012 & -.004 & .003 & -.011 \\
\hline $\begin{array}{l}\text { Black or African } \\
\text { American (R2) }\end{array}$ & -.034 & -.038 & .011 & -.009 & -.009 & -.012 \\
\hline $\begin{array}{l}\text { Hispanic or } \\
\text { Latino (R3) }\end{array}$ & .010 & .016 & .009 & -.005 & -.008 & .015 \\
\hline Asian (R4) & .0130 & -.026 & .002 & .023 & .006 & .028 \\
\hline Other (R5) & .028 & .008 & -.009 & .005 & -.005 & -.011 \\
\hline Male (SG) & .004 & -.022 & -.051 & .008 & .025 & .016 \\
\hline $\begin{array}{l}\text { Do not know } \\
\text { parent's } \\
\text { education level } \\
\text { (SPEL1) }\end{array}$ & -.002 & .006 & -.003 & -.015 & .011 & -.002 \\
\hline
\end{tabular}




\begin{tabular}{|c|c|c|c|c|c|c|}
\hline $\begin{array}{l}\text { Did not complete } \\
\text { high school } \\
\text { (SPEL2) }\end{array}$ & .009 & -.011 & -.003 & -.021 & -.015 & .012 \\
\hline $\begin{array}{l}\text { High school } \\
\text { diploma or } \\
\text { equivalent } \\
\text { (SPEL3) }\end{array}$ & .006 & $\begin{array}{l}.007 \\
\end{array}$ & -.009 & -.014 & -.006 & $\begin{array}{l}.004 \\
\end{array}$ \\
\hline $\begin{array}{l}\text { Vocational or } \\
\text { technical training } \\
\text { (SPEL4) }\end{array}$ & -.001 & -.004 & -.014 & .007 & -.009 & .005 \\
\hline $\begin{array}{l}\text { Less than two } \\
\text { years of college } \\
\text { (SPEL5) }\end{array}$ & -.009 & -.007 & .002 & -.011 & .002 & -.006 \\
\hline $\begin{array}{l}\text { Associate's } \\
\text { degree (SPEL6) }\end{array}$ & -.019 & -.006 & -.005 & -.013 & .003 & .026 \\
\hline $\begin{array}{l}2 \text { or more years } \\
\text { of college but no } \\
\text { degree (SPEL7) }\end{array}$ & .003 & -.002 & .018 & -.001 & -.009 & $\overline{-.016}$ \\
\hline $\begin{array}{l}\text { Bachelor's degree } \\
\text { (SPEL8) }\end{array}$ & .003 & -.007 & -.008 & .017 & -.005 & -.001 \\
\hline $\begin{array}{l}\text { Master's degree } \\
\text { or equivalent } \\
\text { (SPEL9) }\end{array}$ & -.007 & .021 & .009 & .011 & .015 & -.007 \\
\hline $\begin{array}{l}\text { First-professional } \\
\text { degree (SPEL10) }\end{array}$ & .016 & .010 & .005 & .012 & .003 & -.001 \\
\hline $\begin{array}{l}\text { Grade point } \\
\text { average (SGPA) }\end{array}$ & -.053 & .023 & -.008 & .006 & .014 & .002 \\
\hline $\begin{array}{l}\text { Attend institution } \\
\text { in state of legal } \\
\text { residence=Yes } \\
\text { (LOC1) }\end{array}$ & .015 & -.008 & .016 & -.016 & -.001 & -.006 \\
\hline $\begin{array}{l}\text { Attend institution } \\
\text { in state of legal } \\
\text { residence=No } \\
\text { (LOC2) }\end{array}$ & -.012 & .009 & -.011 & .014 & .002 & .001 \\
\hline $\begin{array}{l}\text { Veteran } \\
\text { status }=\text { Not a } \\
\text { veteran (SVA) }\end{array}$ & .001 & .003 & .018 & .012 & -.010 & .009 \\
\hline $\begin{array}{l}\text { Undeclared or } \\
\text { not in a degree } \\
\text { program } \\
\text { (PROGN1) }\end{array}$ & 1 & -.133 & -.139 & -.104 & -.042 & -.034 \\
\hline $\begin{array}{l}\text { Humanities } \\
\text { (PROGN2) }\end{array}$ & -.133 & 1 & -.130 & -.097 & -.039 & -.0320 \\
\hline
\end{tabular}




\begin{tabular}{|l|c|c|r|r|r|r|}
\hline $\begin{array}{l}\text { Social/behavioral } \\
\text { sciences } \\
\text { (PROGN3) }\end{array}$ & -.139 & -.130 & 1 & -.102 & -.041 & -.033 \\
\hline $\begin{array}{l}\text { Life sciences } \\
\text { (PROGN4) }\end{array}$ & -.104 & -.097 & -.102 & 1 & -.031 & -.025 \\
\hline $\begin{array}{l}\text { Physical sciences } \\
\text { (PROGN5) }\end{array}$ & -.042 & -.039 & -.041 & -.031 & 1 & -.010 \\
\hline Math (PROGN6) & -.034 & -.032 & -.033 & -.025 & -.010 & 1 \\
\hline $\begin{array}{l}\text { Computer/ } \\
\text { information } \\
\text { science } \\
\text { (PROGN7) }\end{array}$ & -.078 & -.073 & -.077 & -.058 & -.023 & -.019 \\
\hline $\begin{array}{l}\text { Engineering } \\
\text { (PROGN8) }\end{array}$ & -.097 & -.091 & -.095 & -.071 & -.029 & -.023 \\
\hline $\begin{array}{l}\text { Education } \\
\text { (PROGN9) }\end{array}$ & -.124 & -.116 & -.121 & -.091 & -.036 & -.029 \\
\hline $\begin{array}{l}\text { Business/ } \\
\text { management } \\
\text { (PROGN10) }\end{array}$ & -.164 & -.153 & -.160 & -.120 & -.048 & -.039 \\
\hline $\begin{array}{l}\text { Health } \\
\text { (PROGN11) }\end{array}$ & -.107 & -.100 & -.104 & -.078 & -.031 & -.025 \\
\hline $\begin{array}{l}\text { Vocational/ } \\
\text { technical } \\
\text { (PROGN12) }\end{array}$ & -.0420 & -.039 & -.041 & -.031 & -.012 & -.010 \\
\hline
\end{tabular}

Table 79: Equation 6d correlations (continued)

\begin{tabular}{|l|r|r|r|r|r|}
\hline & $\begin{array}{l}\text { Computer/ } \\
\text { information } \\
\text { science }\end{array}$ & Engineering & Education & $\begin{array}{l}\text { Business/ } \\
\text { management }\end{array}$ & Health \\
\hline $\begin{array}{l}\text { State-need-based } \\
\text { grants (SFPBN) }\end{array}$ & -.011 & .007 & .005 & -.025 & -.006 \\
\hline $\begin{array}{l}\text { Tuition and fees } \\
\text { (T) }\end{array}$ & -.010 & .083 & -.016 & -.007 & -.033 \\
\hline Age (SA) & .018 & -.041 & .023 & .016 & .038 \\
\hline $\begin{array}{l}\text { Adjusted Gross } \\
\text { Income (SAGI) }\end{array}$ & -.006 & .031 & -.014 & .005 & -.019 \\
\hline White (R1) & -.025 & -.008 & .056 & -.033 & .010 \\
\hline $\begin{array}{l}\text { Black or African } \\
\text { American (R2) }\end{array}$ & .023 & .002 & -.023 & .040 & .003 \\
\hline $\begin{array}{l}\text { Hispanic or } \\
\text { Latino (R3) }\end{array}$ & -.022 & -.013 & .001 & -.010 & -.006 \\
\hline Asian (R4) & .047 & .026 & -.060 & .031 & -.011 \\
\hline
\end{tabular}




\begin{tabular}{|c|c|c|c|c|c|}
\hline Other (R5) & .001 & -.006 & -.020 & .008 & -.001 \\
\hline Male (SG) & .148 & .198 & -.157 & .053 & -.130 \\
\hline $\begin{array}{l}\text { Do not know } \\
\text { parent's } \\
\text { education level } \\
\text { (SPEL1) }\end{array}$ & .010 & -.0130 & .001 & .011 & .003 \\
\hline $\begin{array}{l}\text { Did not complete } \\
\text { high school } \\
\text { (SPEL2) }\end{array}$ & -.010 & -.011 & .007 & .013 & .023 \\
\hline $\begin{array}{l}\text { High school } \\
\text { diploma or } \\
\text { equivalent } \\
\text { (SPEL3) }\end{array}$ & -.001 & -.038 & .025 & .010 & .008 \\
\hline $\begin{array}{l}\text { Vocational or } \\
\text { technical training } \\
\text { (SPEL4) }\end{array}$ & .013 & -.002 & -.008 & -.001 & .021 \\
\hline $\begin{array}{l}\text { Less than two } \\
\text { years of college } \\
\text { (SPEL5) }\end{array}$ & -.018 & -.007 & .041 & -.005 & .014 \\
\hline $\begin{array}{l}\text { Associate's } \\
\text { degree (SPEL6) }\end{array}$ & -.006 & -.003 & -.007 & .016 & .013 \\
\hline $\begin{array}{l}2 \text { or more years } \\
\text { of college but no } \\
\text { degree (SPEL7) }\end{array}$ & -.011 & -.007 & .005 & -.005 & .006 \\
\hline $\begin{array}{l}\text { Bachelor's degree } \\
\text { (SPEL8) }\end{array}$ & .013 & .020 & -.014 & -.001 & -.015 \\
\hline $\begin{array}{l}\text { Master's degree } \\
\text { or equivalent } \\
\text { (SPEL9) }\end{array}$ & -.001 & .022 & -.016 & -.003 & -.026 \\
\hline $\begin{array}{l}\text { First-professional } \\
\text { degree (SPEL10) }\end{array}$ & .013 & .013 & -.011 & -.033 & -.007 \\
\hline $\begin{array}{l}\text { Grade point } \\
\text { average (SGPA) }\end{array}$ & -.024 & -.008 & .066 & -.026 & .046 \\
\hline $\begin{array}{l}\text { Attend institution } \\
\text { in state of legal } \\
\text { residence=Yes } \\
\text { (LOC1) }\end{array}$ & -.004 & -.048 & .041 & -.006 & .023 \\
\hline $\begin{array}{l}\text { Attend institution } \\
\text { in state of legal } \\
\text { residence=No } \\
\text { (LOC2) }\end{array}$ & -.006 & .041 & -.033 & -.011 & -.014 \\
\hline $\begin{array}{l}\text { Veteran } \\
\text { status=Not a } \\
\text { veteran (SVA) }\end{array}$ & -.019 & -.010 & .017 & -.002 & -.007 \\
\hline
\end{tabular}




\begin{tabular}{|c|c|c|c|c|c|}
\hline $\begin{array}{l}\text { Undeclared or } \\
\text { not in a degree } \\
\text { program } \\
\text { (PROGN1) }\end{array}$ & -.078 & -.100 & -.124 & -.164 & -.107 \\
\hline $\begin{array}{l}\text { Humanities } \\
\text { (PROGN2) }\end{array}$ & -.073 & -.091 & -.116 & -.153 & -.100 \\
\hline $\begin{array}{l}\text { Social/behavioral } \\
\text { sciences } \\
\text { (PROGN3) }\end{array}$ & -.077 & -.095 & -.121 & -0.160 & -.104 \\
\hline $\begin{array}{l}\text { Life sciences } \\
\text { (PROGN4) }\end{array}$ & -.058 & -.071 & -.091 & -.120 & -.078 \\
\hline $\begin{array}{l}\text { Physical sciences } \\
\text { (PROGN5) }\end{array}$ & -.023 & -.029 & -.036 & -.048 & -.031 \\
\hline Math (PROGN6) & -.019 & -.023 & -.029 & -.039 & -.025 \\
\hline $\begin{array}{l}\text { Computer/ } \\
\text { information } \\
\text { science } \\
\text { (PROGN7) }\end{array}$ & 1 & -.054 & -.068 & -.091 & -.059 \\
\hline $\begin{array}{l}\text { Engineering } \\
\text { (PROGN8) }\end{array}$ & -.054 & 1 & -.085 & -.112 & -.073 \\
\hline $\begin{array}{l}\text { Education } \\
\text { (PROGN9) }\end{array}$ & -.068 & -.085 & 1 & -.143 & -.093 \\
\hline $\begin{array}{l}\text { Business/ } \\
\text { management } \\
(\mathrm{PROGN} 10) \\
\end{array}$ & -.091 & -.112 & -.143 & 1 & -.123 \\
\hline $\begin{array}{l}\text { Health } \\
\text { (PROGN11) }\end{array}$ & -.059 & -.073 & -.093 & -.123 & 1 \\
\hline $\begin{array}{l}\text { Vocational/ } \\
\text { technical } \\
\text { (PROGN12) } \\
\end{array}$ & -.023 & -.029 & -.036 & -.048 & -.031 \\
\hline
\end{tabular}

Table 79: Equation 6d correlations (continued)

\begin{tabular}{|l|r|}
\hline & $\begin{array}{l}\text { Vocational/ } \\
\text { technical }\end{array}$ \\
\hline $\begin{array}{l}\text { State-need-based } \\
\text { grants (SFPBN) }\end{array}$ & -.002 \\
\hline $\begin{array}{l}\text { Tuition and fees } \\
\text { (T) }\end{array}$ & .013 \\
\hline Age (SA) & .012 \\
\hline $\begin{array}{l}\text { Adjusted Gross } \\
\text { Income (SAGI) }\end{array}$ & .001 \\
\hline
\end{tabular}




\begin{tabular}{|c|c|}
\hline White (R1) & .022 \\
\hline $\begin{array}{l}\text { Black or African } \\
\text { American (R2) }\end{array}$ & -.025 \\
\hline $\begin{array}{l}\text { Hispanic or } \\
\text { Latino (R3) }\end{array}$ & -.004 \\
\hline Asian (R4) & -.003 \\
\hline Other (R5) & -.003 \\
\hline Male (SG) & .075 \\
\hline $\begin{array}{l}\text { Do not know } \\
\text { parent's } \\
\text { education level } \\
\text { (SPEL1) }\end{array}$ & -.002 \\
\hline $\begin{array}{l}\text { Did not complete } \\
\text { high school } \\
\text { (SPEL2) }\end{array}$ & .001 \\
\hline $\begin{array}{l}\text { High school } \\
\text { diploma or } \\
\text { equivalent } \\
\text { (SPEL3) }\end{array}$ & .005 \\
\hline $\begin{array}{l}\text { Vocational or } \\
\text { technical training } \\
\text { (SPEL4) }\end{array}$ & -.004 \\
\hline $\begin{array}{l}\text { Less than two } \\
\text { years of college } \\
\text { (SPEL5) }\end{array}$ & .002 \\
\hline $\begin{array}{l}\text { Associate's } \\
\text { degree (SPEL6) }\end{array}$ & -.007 \\
\hline $\begin{array}{l}2 \text { or more years } \\
\text { of college but no } \\
\text { degree (SPEL7) }\end{array}$ & -.011 \\
\hline $\begin{array}{l}\text { Bachelor's degree } \\
\text { (SPEL8) }\end{array}$ & .006 \\
\hline $\begin{array}{l}\text { Master's degree } \\
\text { or equivalent } \\
\text { (SPEL9) }\end{array}$ & .005 \\
\hline $\begin{array}{l}\text { First-professional } \\
\text { degree (SPEL10) }\end{array}$ & -.008 \\
\hline $\begin{array}{l}\text { Grade point } \\
\text { average (SGPA) }\end{array}$ & -.004 \\
\hline $\begin{array}{l}\text { Attend institution } \\
\text { in state of legal } \\
\text { residence=Yes } \\
\text { (LOC1) }\end{array}$ & -.038 \\
\hline
\end{tabular}




\begin{tabular}{|l|c|}
\hline $\begin{array}{l}\text { Attend institution } \\
\text { in state of legal } \\
\text { residence=No } \\
\text { (LOC2) }\end{array}$ & .044 \\
\hline $\begin{array}{l}\text { Veteran } \\
\text { status=Not a } \\
\text { veteran (SVA) }\end{array}$ & -.008 \\
\hline $\begin{array}{l}\text { Undeclared or } \\
\text { not in a degree } \\
\text { program } \\
\text { (PROGN1) }\end{array}$ & -.042 \\
\hline $\begin{array}{l}\text { Humanities } \\
\text { (PROGN2) }\end{array}$ & \\
\hline $\begin{array}{l}\text { Social/behavioral } \\
\text { sciences } \\
\text { (PROGN3) }\end{array}$ & -.039 \\
\hline $\begin{array}{l}\text { Life sciences } \\
\text { (PROGN4) }\end{array}$ & -.041 \\
\hline $\begin{array}{l}\text { Physical sciences } \\
\text { (PROGN5) }\end{array}$ & -.031 \\
\hline Math (PROGN6) & -.012 \\
\hline $\begin{array}{l}\text { Computer/ } \\
\text { information } \\
\text { science } \\
\text { (PROGN7) }\end{array}$ & -.010 \\
\hline $\begin{array}{l}\text { Engineering } \\
\text { (PROGN8) }\end{array}$ & -.023 \\
\hline $\begin{array}{l}\text { Education } \\
\text { (PROGN9) }\end{array}$ & -.039 \\
\hline $\begin{array}{l}\text { Business/ } \\
\text { management } \\
\text { (PROGN10) }\end{array}$ & -.031 \\
\hline $\begin{array}{l}\text { Health } \\
\text { (PROGN11) }\end{array}$ & $\begin{array}{l}\text { Vocational/ } \\
\text { technical } \\
\text { (PROGN12) }\end{array}$ \\
\hline
\end{tabular}

Significant relationships were identified between the amount of institutional need-based financial grant aid paid per student by public institutions and tuition and fees, students ages, adjusted gross incomes; their classifications as Black or African American, Hispanic or Latino, 
and Asian. In addition relationships were noted between the dependent variable and students' gender, the education levels of parents whose educational level were unknown; did not complete high school; received a high school diploma or equivalent; held Associate's degrees; had two years of college but no degree; and received Bachelor's degrees. The analysis also indicates that a relationship exists between the dependent variable and students' grade point averages as well as students' statuses as residents in the state within which the institution is located. Finally, a relationship exists between the dependent variable and students' statuses as veterans. These relationships are represented by the following econometric equation:

$\mathrm{SFPBN}=0.048 \mathrm{~T}+-14.493 \mathrm{SA}+-0.004 \mathrm{SAGI}+129.25 \mathrm{R} 2+272.262 \mathrm{R} 3+370.556 \mathrm{R} 4-$ 48.785SG $\mathrm{SG}_{\mathrm{i}}+289.779 \mathrm{SPEL} 1+315.485 \mathrm{SPEL}_{2}+135.13 \mathrm{SPEL} 3+118.693 \mathrm{SPEL}^{2}+$ 122.408SPEL6 + 0.461SGPA + + LOC1 780.666+ 212.236LOC2 + 105.19SVA -419.41

Research Question 6e: Is there a relationship between the amount of state need-based financial grant aid received at private institutions, the amount of tuition and the fees per student charged to in -state students, and student characteristics and academic programs? Research Question 6e relates to Hypothesis $\left(\mathrm{H}_{6 \mathrm{e}}\right)$, that there is no significant relationship between the amount of need-based state financial grant aid received per student at public institutions, the amount of tuition and the fees per student charged to in-state students, student characteristics and academic programs. As described in Chapter 3, Equation 6e relates to Research Question 6e and Hypothesis 6e:

$\mathrm{SFPVN}_{\mathrm{i}}=\mathrm{T}_{\mathrm{i}}+\mathrm{SA}_{\mathrm{i}}+\mathrm{SAGI}_{\mathrm{i}}+\mathrm{SR}_{\mathrm{i}}+\mathrm{SG}_{\mathrm{i}}+\mathrm{SPEL}_{\mathrm{i}}+\mathrm{SGPA}_{\mathrm{i}}+\mathrm{SVA}_{\mathrm{i}}+\mathrm{LOC}_{\mathrm{i}}$

The significance scores for this equation are displayed in Table 80. The NCES' DAS was used to perform a weighted least squares computation using NPSAS: 04 data. 
Table 80: Equation 6e hypothesis testing results

\begin{tabular}{|l|r|r|r|r|r|}
\hline & \multicolumn{1}{|l|}{ Wald $F$} & $\begin{array}{l}\text { Num. } \\
\text { DF }\end{array}$ & $\begin{array}{l}\text { Denom. } \\
\text { DF }\end{array}$ & Commonality & \multicolumn{2}{l|}{$\begin{array}{l}\text { Probability } \\
F\end{array}$} \\
\hline Overall Fit & 20.292 & 35 & 30 & & .001 \\
\hline Tuition and fees (T) & 86.878 & 1 & 64 & .023 & .001 \\
\hline Age (SA) & 32.960 & 1 & 64 & .011 & .001 \\
\hline $\begin{array}{l}\text { Adjusted Gross Income } \\
\text { (SAGI) }\end{array}$ & 157.149 & 1 & 64 & .028 & .001 \\
\hline Race-ethnicity (SR) & 2.377 & 5 & 60 & .005 & .049 \\
\hline Gender (SG) & \multicolumn{1}{|l|}{7.837} & 1 & 64 & .001 & .007 \\
\hline $\begin{array}{l}\text { Parent's highest } \\
\text { education level (SPEL) }\end{array}$ & 10.831 & 10 & 55 & 0.01 & .001 \\
\hline $\begin{array}{l}\text { Grade point average } \\
\text { (SGPA) }\end{array}$ & .014 & 1 & 64 & 0 & .906 \\
\hline $\begin{array}{l}\text { Attend institution in } \\
\text { state of legal residence } \\
\text { (LOC) }\end{array}$ & 193.383 & 2 & 63 & .079 & .001 \\
\hline Veteran status (SVA) & 1.819 & 1 & 64 & & 0 \\
\hline Program (PROGN) & 1.665 & 12 & 53 & .002 & .182 \\
\hline
\end{tabular}

The variables Grade Point Average (SGPA), Veteran status (VA), and Program (PROGN), were not significant. Because they were not significant, a second computation was completed without these variables. The significance scores for this computation are displayed in Table 81. All the variables in this equation were significant except for race. As a result, a third equation was computed without this variable. The significance scores for this equation are displayed in Table 82 . The variables for this equation were significant. The regression coefficients for this equation are displayed in Table 83. The coefficients for the variables Master's degree or equivalent and First-professional degree were not significant. The coefficient of determination was .1713. From this statistic, we may conclude that 17.13 percent of the variance in state need-based financial grant aid per student paid by private institutions is explained by the independent variables in this equation. 
Table 81: Equation 6e hypothesis testing results second calculation

\begin{tabular}{|l|r|r|r|r|r|}
\hline & Wald $F$ & $\begin{array}{l}\text { Num. } \\
\text { DF }\end{array}$ & $\begin{array}{l}\text { Denom. } \\
\text { DF }\end{array}$ & Commonality & $\begin{array}{l}\text { Probability } \\
F\end{array}$ \\
\hline Overall Fit & 25.525 & 21 & 44 & & .001 \\
\hline $\begin{array}{l}\text { Tuition and } \\
\text { fees (T) }\end{array}$ & 89.661 & 1 & 64 & .024 & .001 \\
\hline Age (SA) & 30.767 & 1 & 64 & .012 & .001 \\
\hline $\begin{array}{l}\text { Adjusted } \\
\text { Gross Income } \\
\text { (SAGI) }\end{array}$ & 149.973 & 1 & 64 & .029 & .001 \\
\hline Race (SR) & 2.257 & 5 & 60 & .005 & .060 \\
\hline Gender (SG) & 11.103 & 1 & 64 & .001 & .001 \\
\hline $\begin{array}{l}\text { Parent's } \\
\text { highest } \\
\text { education } \\
\text { level (SPEL) }\end{array}$ & 11.409 & 10 & 55 & .010 & .001 \\
\hline $\begin{array}{l}\text { Attend } \\
\text { institution in } \\
\text { state of legal } \\
\text { residence } \\
\text { (LOC) }\end{array}$ & 204.842 & 2 & 63 & & .080 \\
\hline
\end{tabular}

Table 82: Equation 6e hypothesis testing results third calculation

\begin{tabular}{|l|r|r|r|r|r|}
\hline & Wald F & $\begin{array}{l}\text { Num. } \\
\text { DF }\end{array}$ & $\begin{array}{l}\text { Denom. } \\
\text { DF }\end{array}$ & Commonality & \multicolumn{2}{l|}{$\begin{array}{l}\text { Probability } \\
F\end{array}$} \\
\hline Overall Fit & 28.837 & 16 & 49 & & .001 \\
\hline $\begin{array}{l}\text { Tuition and fees } \\
\text { (T) }\end{array}$ & 80.735 & 1 & 64 & .023 & .001 \\
\hline Age (SA) & 30.902 & 1 & 64 & .012 & .001 \\
\hline $\begin{array}{l}\text { Adjusted Gross } \\
\text { Income (SAGI) }\end{array}$ & 138.837 & 1 & 64 & .033 & .001 \\
\hline Gender (SG) & 11.638 & 1 & 64 & .001 & .001 \\
\hline $\begin{array}{l}\text { Parent's highest } \\
\text { education level } \\
\text { (SPEL) }\end{array}$ & 11.114 & 10 & 55 & .013 & .001 \\
\hline $\begin{array}{l}\text { Attend institution } \\
\text { in state of legal } \\
\text { residence (LOC) }\end{array}$ & 205.478 & 2 & 63 & .081 & .001 \\
\hline
\end{tabular}


Table 83: Equation 6e estimated full sample regression coefficients

\begin{tabular}{|l|r|r|r|r|}
\hline & \multicolumn{1}{|l}{ B } & \multicolumn{1}{l|}{ s.e. } & \multicolumn{1}{l|}{ Tr } & Probability $t$ \\
\hline Intercept & 118.035 & 132.167 & .893 & .375 \\
\hline Tuition and fees (T) & .031 & .003 & 8.985 & .001 \\
\hline Age (SA) & -22.574 & 4.061 & -5.559 & .001 \\
\hline Adjusted Gross Income (SAGI) & -.006 & .000 & -11.783 & .001 \\
\hline Gender & & & & .001 \\
\hline Male (SG) & -110.411 & 32.365 & -3.411 & \\
\hline vs. Female & & & & .001 \\
\hline Parent's highest education level & & & & .001 \\
\hline $\begin{array}{l}\text { Do not know parent's education } \\
\text { level (SPEL1) }\end{array}$ & 889.574 & 165.274 & 5.382 & .001 \\
\hline $\begin{array}{l}\text { Did not complete high school } \\
\text { (SPEL2) }\end{array}$ & 658.452 & 121.553 & 5.417 & .024 \\
\hline $\begin{array}{l}\text { High school diploma or } \\
\text { equivalent (SPEL3) }\end{array}$ & 414.234 & 90.339 & 4.585 & .001 \\
\hline $\begin{array}{l}\text { Vocational or technical training } \\
\text { (SPEL4) }\end{array}$ & 372.868 & 160.887 & 2.318 & .001 \\
\hline $\begin{array}{l}\text { Less than two years of college } \\
\text { (SPEL5) }\end{array}$ & 408.938 & 110.959 & 3.685 & .001 \\
\hline Associate's degree (SPEL6) & 294.123 & 83.539 & 3.521 & .015 \\
\hline $\begin{array}{l}\text { 2 or more years of college but no } \\
\text { degree (SPEL7) }\end{array}$ & 343.523 & 101.093 & 3.398 & .001 \\
\hline Bachelor's degree (SPEL8) & 155.713 & 62.08 & 2.508 & \\
\hline $\begin{array}{l}\text { Master's degree or equivalent } \\
\text { (SPEL9) }\end{array}$ & 108.058 & 76.768 & 1.408 & \\
\hline $\begin{array}{l}\text { First-professional degree } \\
\text { (SPEL10) }\end{array}$ & -10.364 & 76.542 & -0.135 & .017 \\
\hline vs. Doctoral degree or equivalent & & & & \\
\hline $\begin{array}{l}\text { Attend institution in state of legal } \\
\text { residence }\end{array}$ & 1041.747 & 68.736 & 15.156 & \\
\hline Yes (LOC1) & 104.409 & 42.774 & 2.441 & \\
\hline No (LOC2) & & & & \\
\hline $\begin{array}{l}\text { vs. Foreign or international } \\
\text { student }\end{array}$ & & & & \\
\hline
\end{tabular}

The correlations for this equation are displayed in Table 84 . 
Table 84: Equation 6e correlations

\begin{tabular}{|c|c|c|c|c|c|c|}
\hline & $\begin{array}{l}\text { State- } \\
\text { need- } \\
\text { based } \\
\text { grants }\end{array}$ & $\begin{array}{l}\text { Tuition } \\
\text { and fees }\end{array}$ & Age & $\begin{array}{l}\text { Adjuste } \\
\text { d Gross } \\
\text { Income } \\
\text { (AGI) }\end{array}$ & $\begin{array}{l}\text { Gender= } \\
\text { Male }\end{array}$ & $\begin{array}{l}\text { Parent's highest } \\
\text { education } \\
\text { level=Do not } \\
\text { know parent's } \\
\text { education level }\end{array}$ \\
\hline $\begin{array}{l}\text { State-need- } \\
\text { based grants } \\
\text { SFPVN }\end{array}$ & 1 & .0800 & -.083 & -.209 & -.059 & .061 \\
\hline $\begin{array}{l}\text { Tuition and fees } \\
\text { (T) }\end{array}$ & .0800 & 1 & -.500 & .278 & .041 & -.057 \\
\hline Age (SA) & -.083 & -.500 & 1 & -.177 & -.053 & .075 \\
\hline $\begin{array}{l}\text { Adjusted Gross } \\
\text { Income (SAGI) }\end{array}$ & -.209 & .278 & -.177 & 1 & .027 & -.073 \\
\hline Gender (SG) & -.059 & .041 & -.053 & .027 & 1 & -.011 \\
\hline $\begin{array}{l}\text { Parent's highest } \\
\text { education } \\
\text { level=Do not } \\
\text { know parent's } \\
\text { education level } \\
\text { (SPEL1) }\end{array}$ & .061 & -.057 & .075 & -.073 & -.011 & 1 \\
\hline $\begin{array}{l}\text { Parent's highest } \\
\text { education } \\
\text { level=Did not } \\
\text { complete high } \\
\text { school (SPEL2) }\end{array}$ & .048 & -.118 & .216 & -.100 & -.044 & -.027 \\
\hline $\begin{array}{l}\text { Parent's highest } \\
\text { education } \\
\text { level=High } \\
\text { school diploma } \\
\text { or equivalent } \\
\text { (SPEL3) }\end{array}$ & .054 & -.212 & .209 & -.167 & -.025 & -.069 \\
\hline $\begin{array}{l}\text { Parent's highest } \\
\text { education level= } \\
\text { Vocational or } \\
\text { technical } \\
\text { training } \\
\text { (SPEL4) }\end{array}$ & .025 & -.024 & .038 & -.056 & -.005 & -.024 \\
\hline $\begin{array}{l}\text { Parent's highest } \\
\text { education } \\
\text { level=Less than } \\
\text { two years of } \\
\text { college (SPEL5) }\end{array}$ & .042 & -.030 & -.002 & -.045 & -.026 & -.032 \\
\hline
\end{tabular}




\begin{tabular}{|c|c|c|c|c|c|c|}
\hline $\begin{array}{l}\text { Parent's highest } \\
\text { education } \\
\text { level=Associate' } \\
\text { s degree } \\
\text { (SPEL6) }\end{array}$ & .015 & -.039 & .003 & -.035 & .023 & -.035 \\
\hline $\begin{array}{l}\text { Parent's highest } \\
\text { education } \\
\text { level=2 or more } \\
\text { years of college } \\
\text { but no degree } \\
\text { (SPEL 7) }\end{array}$ & .018 & -.049 & .012 & -.048 & -.013 & -.028 \\
\hline $\begin{array}{l}\text { Parent's highest } \\
\text { education } \\
\text { level=Bachelor's } \\
\text { degree (SPEL8) }\end{array}$ & -.034 & .078 & -.121 & .048 & .021 & -.073 \\
\hline $\begin{array}{l}\text { Parent's highest } \\
\text { education } \\
\text { level=Master's } \\
\text { degree or } \\
\text { equivalent } \\
\text { (SPEL9) }\end{array}$ & -.059 & .146 & -.149 & .153 & .025 & -.061 \\
\hline $\begin{array}{l}\text { Parent's highest } \\
\text { education } \\
\text { level=First- } \\
\text { professional } \\
\text { degree } \\
\text { (SPEL10) }\end{array}$ & -.050 & .127 & -.091 & .104 & .006 & -.026 \\
\hline $\begin{array}{l}\text { Attend } \\
\text { institution in } \\
\text { state of legal } \\
\text { residence =Yes } \\
\text { (LOC1) }\end{array}$ & .284 & -.261 & .218 & -.175 & -.080 & .040 \\
\hline $\begin{array}{l}\text { Attend } \\
\text { institution in } \\
\text { state of legal } \\
\text { residence=No } \\
\text { (LOC2) }\end{array}$ & -.269 & .255 & -.208 & .195 & .062 & -.036 \\
\hline
\end{tabular}


Table 84: Equation 6e correlations (continued)

\begin{tabular}{|c|c|c|c|c|c|}
\hline & $\begin{array}{l}\text { Parent's } \\
\text { highest } \\
\text { education } \\
\text { level=Did } \\
\text { not } \\
\text { complete } \\
\text { high } \\
\text { school }\end{array}$ & $\begin{array}{l}\text { Parent's } \\
\text { highest } \\
\text { education } \\
\text { level } \\
=\text { High } \\
\text { school } \\
\text { diploma } \\
\text { or } \\
\text { equivalent }\end{array}$ & $\begin{array}{l}\text { Parent's } \\
\text { highest } \\
\text { education } \\
\text { level } \\
\text { =Vocational } \\
\text { or technical } \\
\text { training }\end{array}$ & $\begin{array}{l}\text { Parent's } \\
\text { highest } \\
\text { education } \\
\text { level=Less } \\
\text { than two } \\
\text { years of } \\
\text { college }\end{array}$ & $\begin{array}{l}\text { Parent's } \\
\text { highest } \\
\text { education } \\
\text { level= } \\
\text { Associate's } \\
\text { degree }\end{array}$ \\
\hline $\begin{array}{l}\text { State-need- } \\
\text { based grants } \\
\text { SFPVN }\end{array}$ & .048 & .054 & .025 & .042 & .015 \\
\hline $\begin{array}{l}\text { Tuition and fees } \\
\text { (T) }\end{array}$ & -.118 & -.212 & -.024 & -.030 & -.039 \\
\hline Age (SA) & .216 & .209 & .038 & -.002 & .003 \\
\hline $\begin{array}{l}\text { Adjusted Gross } \\
\text { Income (SAGI) }\end{array}$ & -.100 & -.167 & -.056 & -.045 & -.035 \\
\hline Gender (SG) & -.044 & -.025 & -.005 & -.026 & .023 \\
\hline $\begin{array}{l}\text { Parent's highest } \\
\text { education } \\
\text { level=Do not } \\
\text { know parent's } \\
\text { education level } \\
\text { (SPEL1) }\end{array}$ & -.027 & -.069 & -.024 & -.032 & -.035 \\
\hline $\begin{array}{l}\text { Parent's highest } \\
\text { education } \\
\text { level=Did not } \\
\text { complete high } \\
\text { school (SPEL2) }\end{array}$ & 1 & -.110 & -.039 & -.051 & -.055 \\
\hline $\begin{array}{l}\text { Parent's highest } \\
\text { education } \\
\text { level=High } \\
\text { school diploma } \\
\text { or equivalent } \\
\text { (SPEL3) }\end{array}$ & -.110 & 1 & -.099 & -.130 & -.142 \\
\hline $\begin{array}{l}\text { Parent's highest } \\
\text { education } \\
\text { level=Vocationa } \\
1 \text { or technical } \\
\text { training } \\
\text { (SPEL4) }\end{array}$ & -.039 & -.099 & 1 & -.046 & -.050 \\
\hline
\end{tabular}




\begin{tabular}{|c|c|c|c|c|c|}
\hline $\begin{array}{l}\text { Parent's highest } \\
\text { education } \\
\text { level=Less than } \\
\text { two years of } \\
\text { college (SPEL5) }\end{array}$ & -.051 & -.130 & -.046 & 1 & -.065 \\
\hline $\begin{array}{l}\text { Parent's highest } \\
\text { education level= } \\
\text { Associate's } \\
\text { degree (SPEL6) }\end{array}$ & -.055 & -.142 & -.050 & -.065 & 1 \\
\hline $\begin{array}{l}\text { Parent's highest } \\
\text { education } \\
\text { level=2 or more } \\
\text { years of college } \\
\text { but no degree } \\
\text { (SPEL7) }\end{array}$ & -.044 & -.113 & -.040 & -.052 & -.057 \\
\hline $\begin{array}{l}\text { Parent's highest } \\
\text { education } \\
\text { level=Bachelor's } \\
\text { degree (SPEL8) }\end{array}$ & -.116 & -.297 & -.104 & -.137 & -.149 \\
\hline $\begin{array}{l}\text { Parent's highest } \\
\text { education } \\
\text { level=Master's } \\
\text { degree or } \\
\text { equivalent } \\
\text { (SPEL9) }\end{array}$ & \begin{tabular}{l|l}
-097 \\
\end{tabular} & -2500 & -.088 & -.115 & -.125 \\
\hline $\begin{array}{l}\text { Parent's highest } \\
\text { education } \\
\text { level=First- } \\
\text { professional } \\
\text { degree } \\
\text { (SPEL10) }\end{array}$ & -.041 & -.106 & -.037 & -.049 & -.053 \\
\hline $\begin{array}{l}\text { Attend } \\
\text { institution in } \\
\text { state of legal } \\
\text { residence=Yes } \\
\text { (LOC1) }\end{array}$ & .075 & .107 & .031 & .041 & .034 \\
\hline $\begin{array}{l}\text { Attend } \\
\text { institution in } \\
\text { state of legal } \\
\text { residence=No } \\
\text { (LOC2) }\end{array}$ & $\begin{array}{l}-.073 \\
\end{array}$ & -.103 & -.032 & -.035 & $\begin{array}{l}.031 \\
\end{array}$ \\
\hline
\end{tabular}


Table 84: Equation 6e correlations (continued)

\begin{tabular}{|c|c|c|c|c|c|c|}
\hline & $\begin{array}{l}\text { Parent's } \\
\text { highest } \\
\text { education } \\
\text { level=2 or } \\
\text { more } \\
\text { years of } \\
\text { college } \\
\text { but no } \\
\text { degree }\end{array}$ & $\begin{array}{l}\text { Parent's } \\
\text { highest } \\
\text { education } \\
\text { level= } \\
\text { Bachelor's } \\
\text { degree }\end{array}$ & $\begin{array}{l}\text { Parent's } \\
\text { highest } \\
\text { education } \\
\text { level = } \\
\text { Master's } \\
\text { degree or } \\
\text { equivalent }\end{array}$ & $\begin{array}{l}\text { Parent's } \\
\text { highest } \\
\text { education } \\
\text { level= } \\
\text { First- } \\
\text { profession } \\
\text { al degree }\end{array}$ & $\begin{array}{l}\text { Attend } \\
\text { institution } \\
\text { in state of } \\
\text { legal } \\
\text { residence } \\
=\text { Yes }\end{array}$ & $\begin{array}{l}\text { Attend } \\
\text { institutio } \\
\mathrm{n} \text { in } \\
\text { state of } \\
\text { legal } \\
\text { residenc } \\
\mathrm{e}=\mathrm{No}\end{array}$ \\
\hline $\begin{array}{l}\text { State-need-based } \\
\text { grants SFPVN }\end{array}$ & .018 & -.034 & -.059 & -.0500 & .284 & -.269 \\
\hline $\begin{array}{l}\text { Tuition and fees } \\
\text { (T) }\end{array}$ & -.049 & .078 & .146 & .127 & -.261 & .255 \\
\hline Age (SA) & .012 & -.121 & -.149 & -.091 & .218 & -.208 \\
\hline $\begin{array}{l}\text { Adjusted Gross } \\
\text { Income (SAGI) }\end{array}$ & -.048 & .048 & .153 & .104 & -.175 & .195 \\
\hline Gender (SG) & -.013 & .021 & .025 & .006 & -.080 & .062 \\
\hline $\begin{array}{l}\text { Parent's highest } \\
\text { education } \\
\text { level=Do not } \\
\text { know parent's } \\
\text { education level } \\
\text { (SPEL1) }\end{array}$ & -.028 & -.073 & -.061 & -.026 & .040 & -.036 \\
\hline $\begin{array}{l}\text { Parent's highest } \\
\text { education } \\
\text { level=Did not } \\
\text { complete high } \\
\text { school (SPEL2) }\end{array}$ & -.044 & -.116 & -.097 & -.041 & .075 & -.073 \\
\hline $\begin{array}{l}\text { Parent's highest } \\
\text { education } \\
\text { level=High school } \\
\text { diploma or } \\
\text { equivalent } \\
\text { (SPEL3) }\end{array}$ & -.113 & -.297 & -.2500 & -.106 & .107 & -.103 \\
\hline $\begin{array}{l}\text { Parent's highest } \\
\text { education } \\
\text { level=Vocational } \\
\text { or technical } \\
\text { training (SPEL4) }\end{array}$ & -.040 & -.104 & -.088 & -.037 & .031 & -.032 \\
\hline
\end{tabular}




\begin{tabular}{|c|c|c|c|c|c|c|}
\hline $\begin{array}{l}\text { Parent's highest } \\
\text { education } \\
\text { level=Less than } \\
\text { two years of } \\
\text { college (SPEL5) }\end{array}$ & -.052 & -.137 & -.115 & -.049 & .041 & -.035 \\
\hline $\begin{array}{l}\text { Parent's highest } \\
\text { education } \\
\text { level=Associate's } \\
\text { degree (SPEL6) }\end{array}$ & -.057 & -.149 & -.125 & -.053 & .034 & -.031 \\
\hline $\begin{array}{l}\text { Parent's highest } \\
\text { education level=2 } \\
\text { or more years of } \\
\text { college but no } \\
\text { degree (SPEL7) }\end{array}$ & 1 & -.118 & -.099 & -.042 & .022 & -.018 \\
\hline $\begin{array}{l}\text { Parent's highest } \\
\text { education } \\
\text { level=Bachelor's } \\
\text { degree (SPEL8) }\end{array}$ & -.118 & 1 & -.263 & -.112 & -.052 & .046 \\
\hline $\begin{array}{l}\text { Parent's highest } \\
\text { education } \\
\text { level=Master's } \\
\text { degree or } \\
\text { equivalent } \\
\text { (SPEL9) }\end{array}$ & -.099 & -.263 & 1 & -.094 & -.092 & .087 \\
\hline $\begin{array}{l}\text { Parent's highest } \\
\text { education } \\
\text { level=First- } \\
\text { professional } \\
\text { degree (SPEL10) }\end{array}$ & -.042 & -.112 & -.094 & 1 & -.096 & .090 \\
\hline $\begin{array}{l}\text { Attend institution } \\
\text { in state of legal } \\
\text { residence =Yes } \\
\text { (LOC1) }\end{array}$ & .022 & -.052 & -.092 & -.096 & 1 & -.947 \\
\hline $\begin{array}{l}\text { Attend institution } \\
\text { in state of legal } \\
\text { residence=No } \\
(\text { LOC2) }\end{array}$ & -.018 & .046 & .087 & .090 & -.947 & 1 \\
\hline
\end{tabular}


Table 84: Equation 6e correlations (continued)

\begin{tabular}{|l|r|}
\hline & $\begin{array}{l}\text { Attend } \\
\text { institution } \\
\text { in state of } \\
\text { legal } \\
\text { residence } \\
\text { =No }\end{array}$ \\
\hline $\begin{array}{l}\text { State-need-based } \\
\text { grants SFPVN }\end{array}$ & -.269 \\
\hline $\begin{array}{l}\text { Tuition and fees } \\
\text { (T) }\end{array}$ & .255 \\
\hline Age (SA) & -.208 \\
\hline $\begin{array}{l}\text { Adjusted Gross } \\
\text { Income (SAGI) }\end{array}$ & .195 \\
\hline Gender (SG) & .062 \\
\hline $\begin{array}{l}\text { Parent's highest } \\
\text { education } \\
\text { level=Do not } \\
\text { know parent's } \\
\text { education level } \\
\text { (SPEL1) }\end{array}$ & -.036 \\
\hline $\begin{array}{l}\text { Parent's highest } \\
\text { education } \\
\text { level=Did not } \\
\text { complete high } \\
\text { school (SPEL2) }\end{array}$ & -.073 \\
\hline $\begin{array}{l}\text { Parent's highest } \\
\text { education } \\
\text { level=High school } \\
\text { diploma or } \\
\text { equivalent } \\
\text { (SPEL3) }\end{array}$ \\
\hline $\begin{array}{l}\text { Parent's highest } \\
\text { education } \\
\text { level=Vocational } \\
\text { or technical } \\
\text { training (SPEL4) }\end{array}$ \\
\hline $\begin{array}{l}\text { Parent's highest } \\
\text { education } \\
\text { level=Less than } \\
\text { two years of } \\
\text { college (SPEL5) }\end{array}$ \\
\hline
\end{tabular}




\begin{tabular}{|c|c|}
\hline $\begin{array}{l}\text { Parent's highest } \\
\text { education } \\
\text { level=Associate's } \\
\text { degree (SPEL6) }\end{array}$ & -.031 \\
\hline $\begin{array}{l}\text { Parent's highest } \\
\text { education level=2 } \\
\text { or more years of } \\
\text { college but no } \\
\text { degree (SPEL7) }\end{array}$ & -.018 \\
\hline $\begin{array}{l}\text { Parent's highest } \\
\text { education } \\
\text { level=Bachelor's } \\
\text { degree (SPEL8) }\end{array}$ & .046 \\
\hline $\begin{array}{l}\text { Parent's highest } \\
\text { education } \\
\text { level=Master's } \\
\text { degree or } \\
\text { equivalent } \\
\text { (SPEL9) }\end{array}$ & .087 \\
\hline $\begin{array}{l}\text { Parent's highest } \\
\text { education } \\
\text { level=First- } \\
\text { professional } \\
\text { degree (SPEL10) }\end{array}$ & .090 \\
\hline $\begin{array}{l}\text { Attend institution } \\
\text { in state of legal } \\
\text { residence =Yes } \\
\text { (LOC1) }\end{array}$ & -.947 \\
\hline $\begin{array}{l}\text { Attend institution } \\
\text { in state of legal } \\
\text { residence=No } \\
\text { (LOC2) }\end{array}$ & 1 \\
\hline
\end{tabular}

Significant relationships were identified between the amount of institutional need-based financial grant aid paid per student by private institutions and tuition and fees, students ages, and students' classifications as male In addition relationships were noted between the dependent variable and the education levels of parents whose educational level were unknown; did not complete high school; received a high school diploma or equivalent; received vocational or 
technical training; had less than two years of college; held Associate's degree; had two years of college but no degree; and received a Bachelor's degree. The analysis also indicates that a relationship exists between the dependent variable and students' statuses as residents in the state within which the institutions are located and students' statuses as non-residents of the state within which the institutions are located. These relationships are represented by the following econometric equation:

$$
\begin{aligned}
& \text { SFPVN }=0.031 \mathrm{~T}-22.574 \text { SA -0.006 SAGI -110.411SG + 889.574SPEL1 + } \\
& \text { 658.452SPEL2 + 414.234SPEL3 + 372.868SPEL4 + 408.938SPEL5 + 294.123SPEL6 + } \\
& \text { 343.523SPEL7 + 155.713SPEL8 + 1041.747LOC1 + 104.409LOC } 2+118.035
\end{aligned}
$$

\section{Research Question 6f: Does the amount of state need-based financial grant aid} received by students at public institutions differ significantly from the amount of state needbased financial grant aid received by students at private institutions? Research Question $6 \mathrm{f}$ relates to Hypothesis $\left(\mathrm{H}_{6 \mathrm{f}}\right)$, that the amount of state need-based financial grant aid per student received at public institutions was less than or equal to the amount of state need-based financial grant aid per student received at private institutions.

As described in Chapter 3, Equation $6 \mathrm{f}$ relates to Research Question $6 \mathrm{f}$ and Hypothesis

6f:

$$
\mathrm{SFPBN} \leq \mathrm{SFPVN}
$$

The data used for the means comparison are displayed in Table 85. The following formula was used to calculate the $t$ value:

$$
t_{d f}=\frac{\left|\bar{x}_{A}-\bar{x}_{B}\right|}{\sqrt{\hat{V}_{A}+\hat{V}_{B}}}
$$


The means for the two groups that were compared are represented by $\bar{x}_{A}$ and $\bar{x}_{B}$. The respective squared standard errors associated with the means are represented by $\hat{V}_{A}$ and $\hat{V}_{B}$.

The $t$ value for the comparison of the two means was 11.25. Because the test statistic exceeds the critical value of \pm 1.96 , the difference between the two means is statistically significant.

Table 85: Equation 6f group statistics

\begin{tabular}{|l|c|r|}
\hline & Mean & Standard Error \\
\hline Public Institutions & 172.302 & 5.949 \\
\hline Private Institutions & 548.621 & 32.910 \\
\hline
\end{tabular}

\section{Research Question 7a: Is there a relationship between the amount of federal grants,} veteran and tax benefits received per student at public institutions, the amount of tuition and fees paid per student, student characteristics, and the economic and political characteristics of the states? Research Question 7a relates to Hypothesis $\left(\mathrm{H}_{7 \mathrm{a}}\right)$, that there is no significant relationship between the amount of federal grants, veteran, and tax benefits received per student by public institutions, the amount of tuition and fees per student charged to in-state students, student characteristics, and the economic and political characteristics of the states. As described in Chapter 3, Equation 7a1 and relates to Research Question 7a and Hypothesis 7a:

$$
\mathrm{FFPB}_{\mathrm{i}}=\mathrm{T}_{\mathrm{i}}+\mathrm{SA}_{\mathrm{i}}+\mathrm{SAGI}_{\mathrm{i}}+\mathrm{SR}_{\mathrm{i}}+\mathrm{SG}_{\mathrm{i}}+\mathrm{SPEL}_{\mathrm{i}}+\mathrm{SGPA}_{\mathrm{i}}+\mathrm{SVA}_{\mathrm{i}}+\mathrm{LOC}_{\mathrm{i}}
$$

The significance scores for this equation are displayed in Table 86. The NCES' DAS was used to perform a weighted least squares computation using NPSAS: 04 data.

Table 86: Equation 7a hypothesis testing results

\begin{tabular}{|l|r|r|r|r|r|}
\hline & Wald $F$ & $\begin{array}{l}\text { Num. } \\
\text { DF }\end{array}$ & $\begin{array}{l}\text { Denom. } \\
\text { DF }\end{array}$ & Commonality & \multicolumn{2}{l|}{$\begin{array}{l}\text { Probability } \\
F\end{array}$} \\
\hline Overall Fit & 160.765 & 23 & 42 & & .001 \\
\hline Tuition and fees (T) & 285.407 & 1 & 64 & .028 & .001 \\
\hline Age (SA) & 94.480 & 1 & 64 & .007 & .001 \\
\hline
\end{tabular}




\begin{tabular}{|l|r|r|r|r|r|}
\hline $\begin{array}{l}\text { Adjusted Gross Income } \\
\text { (SAGI) }\end{array}$ & 2293.866 & 1 & 64 & .120 & .001 \\
\hline Race (SR) & 9.031 & 5 & 60 & .006 & .001 \\
\hline Gender (SG) & 0.829 & 1 & 64 & .000 & .366 \\
\hline $\begin{array}{l}\text { Parent's highest } \\
\text { education level (SPEL) }\end{array}$ & 15.562 & 10 & 55 & .008 & .001 \\
\hline $\begin{array}{l}\text { Grade point average } \\
\text { (SGPA) }\end{array}$ & 10.647 & 1 & 64 & .001 & .002 \\
\hline Veteran status (SVA) & 57.731 & 1 & 64 & .029 & .001 \\
\hline $\begin{array}{l}\text { Attend institution in } \\
\text { state of legal residence } \\
\text { (LOC) }\end{array}$ & 154.000 & 2 & 63 & .012 & .001 \\
\hline
\end{tabular}

All the variables in this equation were significant except for Gender (SG). A second equation was computed without this variable. The significance scores for this equation are displayed in Table 87. All of the variables for this equation were significant. The coefficient of determination was .226. From this statistic, we may conclude that 22.6 percent of the variance in federal financial grant aid per student paid by public institutions is explained by the independent variables in this equation. The coefficients for the race variables White, Hispanics or Latino, Asian and Other were not significant. The coefficients for the variables Master's degree or equivalent and First-professional degree were also not significant. The regression coefficients for this equation are displayed in Table 88.

Table 87: Equation 7a hypothesis testing results second calculation

\begin{tabular}{|l|r|r|r|r|r|}
\hline & Wald F & $\begin{array}{l}\text { Num. } \\
\text { DF }\end{array}$ & $\begin{array}{l}\text { Denom. } \\
\text { DF }\end{array}$ & Commonality & $\begin{array}{l}\text { Probability } \\
F\end{array}$ \\
\hline Overall Fit & 169.254 & 22 & 43 & & .001 \\
\hline Tuition and fees (T) & 286.195 & 1 & 64 & .028 & .001 \\
\hline Age (SA) & 93.235 & 1 & 64 & .007 & .001 \\
\hline $\begin{array}{l}\text { Adjusted Gross Income } \\
\text { (SAGI) }\end{array}$ & 2312.889 & 1 & 64 & .120 & .001 \\
\hline Race (SR) & 8.993 & 5 & 60 & .006 & .001 \\
\hline $\begin{array}{l}\text { Parent's highest education } \\
\text { level (SPEL) }\end{array}$ & 16.156 & 10 & 55 & .009 & .001 \\
\hline $\begin{array}{l}\text { Grade point average } \\
\text { (SGPA) }\end{array}$ & 10.576 & 1 & 64 & .000 & .002 \\
\hline
\end{tabular}




\begin{tabular}{|l|r|r|r|r|r|}
\hline Veteran status (SVA) & 56.843 & 1 & 64 & .029 & .001 \\
\hline $\begin{array}{l}\text { Attend institution in state } \\
\text { of legal residence (LOC) }\end{array}$ & 156.759 & 2 & 63 & .012 & .001 \\
\hline
\end{tabular}

Table 88: Equation 7a estimated full sample regression coefficients

\begin{tabular}{|c|c|c|c|c|}
\hline & $\mathrm{b}$ & s.e. & $T$ & Probability $t$ \\
\hline Intercept & 2630.273 & 315.948 & 8.325 & .001 \\
\hline Tuition and fees (T) & .106 & .006 & 16.917 & .001 \\
\hline Age (SA) & -20.688 & 2.143 & -9.656 & .001 \\
\hline Adjusted Gross Income (SAGI) & -.013 & .000 & -48.093 & .001 \\
\hline \multicolumn{5}{|l|}{ Race } \\
\hline White (R1) & -114.367 & 87.625 & -1.305 & .196 \\
\hline Black or African American (R2) & 309.399 & 103.555 & 2.988 & .004 \\
\hline Hispanic or Latino (R3) & 106.824 & 108.305 & .986 & .328 \\
\hline Asian (R4) & -14.741 & 97.139 & -.152 & .880 \\
\hline Other (R5) & -69.136 & 112.802 & -.613 & .542 \\
\hline \multicolumn{5}{|l|}{ vs. More than one race } \\
\hline \multicolumn{5}{|l|}{ Parent's highest education level } \\
\hline $\begin{array}{l}\text { Do not know parent's education level } \\
\text { (SPEL1) }\end{array}$ & 628.891 & 126.047 & 4.989 & .001 \\
\hline Did not complete high school (SPEL2) & 727.771 & 76.087 & 9.565 & .001 \\
\hline $\begin{array}{l}\text { High school diploma or equivalent } \\
\text { (SPEL3) }\end{array}$ & 389.839 & 55.205 & 7.062 & .001 \\
\hline $\begin{array}{l}\text { Vocational or technical training } \\
\text { (SPEL4) }\end{array}$ & 261.529 & 71.938 & 3.635 & .001 \\
\hline $\begin{array}{l}\text { Less than two years of college } \\
\text { (SPEL5) }\end{array}$ & 436.044 & 59.658 & 7.309 & .001 \\
\hline Associate's degree (SPEL6) & 236.769 & 64.702 & 3.659 & .001 \\
\hline $\begin{array}{l}2 \text { or more years of college but no } \\
\text { degree (SPEL7) }\end{array}$ & 363.316 & 81.605 & 4.452 & .001 \\
\hline Bachelor's degree (SPEL8) & 164.540 & 56.303 & 2.922 & .005 \\
\hline Master's degree or equivalent (SPEL9) & 111.555 & 56.419 & 1.977 & .052 \\
\hline First-professional degree (SPEL10) & 55.621 & 83.854 & 0.663 & .510 \\
\hline \multicolumn{5}{|l|}{$\begin{array}{l}\text { vs. Doctoral degree or equivalent } \\
\text { (SPEL11) }\end{array}$} \\
\hline Grade point average (SGPA) & -0.539 & 0.166 & -3.252 & .002 \\
\hline \multicolumn{5}{|l|}{ Veteran status } \\
\hline Not a veteran (SVA) & -2147.721 & 284.866 & -7.539 & .001 \\
\hline \multicolumn{5}{|l|}{ vs. Veteran } \\
\hline \multicolumn{5}{|l|}{$\begin{array}{l}\text { Attend institution in state of legal } \\
\text { residence }\end{array}$} \\
\hline Yes (LOC1) & 1396.081 & 87.872 & 15.888 & .001 \\
\hline No (LOC2) & 992.099 & 98.132 & 10.110 & .001 \\
\hline
\end{tabular}


vs. Foreign or international student

The correlations for this equation are displayed in Table 89.

Table 89: Equation 7a correlations

\begin{tabular}{|c|c|c|c|c|c|c|}
\hline & $\begin{array}{l}\text { Total federal } \\
\text { grants, } \\
\text { veteran, and } \\
\text { tax benefits }\end{array}$ & $\begin{array}{l}\text { Tuition } \\
\text { and Fees }\end{array}$ & Age & $\begin{array}{l}\text { Adjusted } \\
\text { Gross } \\
\text { Income } \\
\text { (AGI) }\end{array}$ & White & $\begin{array}{l}\text { Black or } \\
\text { African } \\
\text { American }\end{array}$ \\
\hline $\begin{array}{l}\text { Total federal } \\
\text { grants, } \\
\text { veteran, and } \\
\text { tax benefits } \\
(\text { FFPB) }\end{array}$ & 1 & .093 & -.011 & -.373 & -.135 & .129 \\
\hline $\begin{array}{l}\text { Tuition and } \\
\text { Fees }(\mathrm{T})\end{array}$ & .093 & 1 & -.263 & .163 & .020 & .006 \\
\hline Age (SA) & -.011 & -.263 & 1 & -.181 & -.038 & .067 \\
\hline $\begin{array}{l}\text { Adjusted } \\
\text { Gross Income } \\
\text { (SAGI) }\end{array}$ & -.373 & .163 & -.181 & 1 & .171 & -.132 \\
\hline White (R1) & -.135 & .0200 & -.038 & .171 & 1 & -.532 \\
\hline $\begin{array}{l}\text { Black or } \\
\text { African } \\
\text { American } \\
\text { (R2) }\end{array}$ & .129 & .006 & .067 & -.132 & -.532 & 1 \\
\hline $\begin{array}{l}\text { Hispanic or } \\
\text { Latino (R3) }\end{array}$ & .061 & -.076 & .001 & -.082 & -.463 & -.102 \\
\hline Asian (R4) & .019 & .063 & -.036 & -.044 & -.392 & -.086 \\
\hline Other (R5) & .004 & -.030 & .032 & -.030 & -.256 & -.057 \\
\hline $\begin{array}{l}\text { Do not know } \\
\text { parent's } \\
\text { education } \\
\text { level (SPEL1) }\end{array}$ & .056 & -.013 & .069 & -.065 & -.103 & .036 \\
\hline $\begin{array}{l}\text { Did not } \\
\text { complete high } \\
\text { school } \\
\text { (SPEL2) }\end{array}$ & .083 & -.065 & .151 & -.106 & -.163 & .036 \\
\hline $\begin{array}{l}\text { High school } \\
\text { diploma or } \\
\text { equivalent } \\
\text { (SPEL3) }\end{array}$ & .086 & -.083 & .125 & -.154 & -.033 & .053 \\
\hline $\begin{array}{l}\text { Vocational or } \\
\text { technical }\end{array}$ & .003 & -.008 & .026 & -.018 & .009 & .001 \\
\hline
\end{tabular}




\begin{tabular}{|c|c|c|c|c|c|c|}
\hline \multicolumn{7}{|l|}{$\begin{array}{l}\text { training } \\
\text { (SPEL4) }\end{array}$} \\
\hline $\begin{array}{l}\text { Less than two } \\
\text { years of } \\
\text { college } \\
\text { (SPEL5) }\end{array}$ & .048 & -.016 & -.004 & -.044 & -.005 & .016 \\
\hline $\begin{array}{l}\text { Associate's } \\
\text { degree } \\
\text { (SPEL6) }\end{array}$ & .004 & -.0120 & $\begin{array}{l}.004 \\
\end{array}$ & -.020 & -.008 & .021 \\
\hline $\begin{array}{l}2 \text { or more } \\
\text { years of } \\
\text { college but no } \\
\text { degree } \\
\text { (SPEL7) }\end{array}$ & .027 & -.026 & .011 & -.039 & -.012 & .040 \\
\hline $\begin{array}{l}\text { Bachelor's } \\
\text { degree } \\
\text { (SPEL8) }\end{array}$ & -.068 & .038 & -.100 & .096 & .068 & -.053 \\
\hline $\begin{array}{l}\text { Master's } \\
\text { degree or } \\
\text { equivalent } \\
\text { (SPEL9) }\end{array}$ & -.077 & .077 & -.098 & .125 & .067 & -.048 \\
\hline $\begin{array}{l}\text { First- } \\
\text { professional } \\
\text { degree } \\
\text { (SPEL10) } \\
\end{array}$ & -.035 & .041 & -.033 & .058 & .015 & -.020 \\
\hline $\begin{array}{l}\text { Grade point } \\
\text { average } \\
\text { (SGPA) }\end{array}$ & -.057 & .063 & .133 & .048 & .121 & -.132 \\
\hline $\begin{array}{l}\text { Veteran Status } \\
\text { (SVA) }\end{array}$ & -.176 & .056 & -.202 & .056 & .011 & -.021 \\
\hline $\begin{array}{l}\text { Attend } \\
\text { institution in } \\
\text { state of legal } \\
\text { residence } \\
=\text { Yes (LOC1) }\end{array}$ & .017 & -.559 & .095 & -.076 & .028 & -.039 \\
\hline $\begin{array}{l}\text { Attend } \\
\text { institution in } \\
\text { state of legal } \\
\text { residence=No } \\
\text { (LOC2) }\end{array}$ & .007 & .524 & -.097 & .100 & .025 & .033 \\
\hline
\end{tabular}


Table 89: Equation 7a correlations (continued)

\begin{tabular}{|c|c|c|c|c|c|c|}
\hline & $\begin{array}{l}\text { Hispanic } \\
\text { or Latino }\end{array}$ & Asian & Other & $\begin{array}{l}\text { Do not } \\
\text { know } \\
\text { parent's } \\
\text { education } \\
\text { level }\end{array}$ & $\begin{array}{l}\text { Did not } \\
\text { complete } \\
\text { high } \\
\text { school }\end{array}$ & $\begin{array}{l}\text { High school } \\
\text { diploma or } \\
\text { equivalent }\end{array}$ \\
\hline $\begin{array}{l}\text { Total federal } \\
\text { grants, } \\
\text { veteran, and } \\
\text { tax benefits } \\
\text { (FFPB) }\end{array}$ & .061 & .019 & .004 & .056 & .083 & .086 \\
\hline $\begin{array}{l}\text { Tuition and } \\
\text { Fees (T) }\end{array}$ & -.076 & .063 & -0.030 & -.013 & -.065 & -.083 \\
\hline Age (SA) & .001 & -.036 & .032 & .069 & .151 & .125 \\
\hline $\begin{array}{l}\text { Adjusted } \\
\text { Gross Income } \\
\text { (SAGI) }\end{array}$ & -.082 & -.044 & -.030 & -.065 & -.106 & -.154 \\
\hline White (R1) & -.463 & -.392 & -.256 & -.103 & -.163 & -.033 \\
\hline $\begin{array}{l}\text { Black or } \\
\text { African } \\
\text { American } \\
\text { (R2) }\end{array}$ & -.102 & -.086 & -.057 & .036 & .036 & .053 \\
\hline $\begin{array}{l}\text { Hispanic or } \\
\text { Latino (R3) }\end{array}$ & 1 & -.075 & -.049 & .040 & .181 & .025 \\
\hline Asian (R4) & -.075 & 1 & -.042 & .085 & .055 & -.015 \\
\hline Other (R5) & -.049 & -.042 & 1 & .026 & .023 & -.009 \\
\hline $\begin{array}{l}\text { Do not know } \\
\text { parent's } \\
\text { education } \\
\text { level (SPEL1) }\end{array}$ & .040 & .085 & .026 & 1 & -.026 & -.069 \\
\hline $\begin{array}{l}\text { Did not } \\
\text { complete high } \\
\text { school } \\
\text { (SPEL2) }\end{array}$ & .181 & .055 & .023 & -.026 & 1 & -.107 \\
\hline $\begin{array}{l}\text { High school } \\
\text { diploma or } \\
\text { equivalent } \\
\text { (SPEL3) }\end{array}$ & .025 & -.015 & -.009 & -.069 & -.107 & 1 \\
\hline $\begin{array}{l}\text { Vocational or } \\
\text { technical } \\
\text { training } \\
\text { (SPEL4) } \\
\end{array}$ & .004 & -.014 & -.014 & -.025 & -.039 & -.104 \\
\hline $\begin{array}{l}\text { Less than two } \\
\text { years of } \\
\text { college }\end{array}$ & .015 & -.023 & -.008 & -.035 & -.054 & -.145 \\
\hline
\end{tabular}




\begin{tabular}{|c|c|c|c|c|c|c|}
\hline (SPEL5) & & & & & & \\
\hline $\begin{array}{l}\text { Associate's } \\
\text { degree } \\
\text { (SPEL6) }\end{array}$ & -.011 & -.005 & -.009 & -.037 & -.056 & -.150 \\
\hline $\begin{array}{l}2 \text { or more } \\
\text { years of } \\
\text { college but no } \\
\text { degree } \\
\text { (SPEL7) }\end{array}$ & -.003 & -.019 & -.021 & -.028 & -.044 & -.116 \\
\hline $\begin{array}{l}\text { Bachelor's } \\
\text { degree } \\
\text { (SPEL8) } \\
\end{array}$ & -.055 & -.009 & .006 & -.077 & -.118 & -.316 \\
\hline $\begin{array}{l}\text { Master's } \\
\text { degree or } \\
\text { equivalent } \\
\text { (SPEL9) }\end{array}$ & -0.050 & -.009 & .009 & -.059 & -.090 & -.241 \\
\hline $\begin{array}{l}\text { First- } \\
\text { professional } \\
\text { degree } \\
\text { (SPEL10) }\end{array}$ & -.015 & .011 & .001 & -.021 & -.032 & -.086 \\
\hline $\begin{array}{l}\text { Grade point } \\
\text { average } \\
\text { (SGPA) }\end{array}$ & -.054 & .016 & -.009 & -.027 & -.004 & -.045 \\
\hline $\begin{array}{l}\text { Veteran Status } \\
\text { (SVA) }\end{array}$ & .007 & .012 & -.021 & -.038 & -.014 & -.039 \\
\hline $\begin{array}{l}\text { Attend } \\
\text { institution in } \\
\text { state of legal } \\
\text { residence } \\
=\text { Yes (LOC1) }\end{array}$ & .043 & -.064 & .014 & .010 & .032 & .040 \\
\hline $\begin{array}{l}\text { Attend } \\
\text { institution in } \\
\text { state of legal } \\
\text { residence=No } \\
\text { (LOC2) }\end{array}$ & -.048 & -.020 & -.021 & -.019 & -.035 & -.039 \\
\hline
\end{tabular}

Table 89: Equation 7a correlations (continued)

\begin{tabular}{|l|l|l|l|l|l|l|}
\hline & $\begin{array}{l}\text { Vocational } \\
\text { or } \\
\text { technical } \\
\text { training }\end{array}$ & $\begin{array}{l}\text { Less } \\
\text { than two } \\
\text { years of } \\
\text { college }\end{array}$ & $\begin{array}{l}\text { Associate's } \\
\text { degree }\end{array}$ & $\begin{array}{l}2 \text { or } \\
\text { more } \\
\text { years of } \\
\text { college } \\
\text { but no } \\
\text { degree }\end{array}$ & $\begin{array}{l}\text { Bachelor's } \\
\text { degree }\end{array}$ & $\begin{array}{l}\text { Master's } \\
\text { degree or } \\
\text { equivalent }\end{array}$ \\
\hline
\end{tabular}




\begin{tabular}{|c|c|c|c|c|c|c|}
\hline & .003 & .048 & .004 & .027 & -.068 & -.077 \\
\hline $\begin{array}{l}\text { Total federal } \\
\text { grants, } \\
\text { veteran, and } \\
\text { tax benefits } \\
\text { (FFPB) }\end{array}$ & -.008 & -.016 & -.020 & -.026 & .038 & .077 \\
\hline $\begin{array}{l}\text { Tuition and } \\
\text { Fees (T) }\end{array}$ & .026 & -.004 & -.004 & .011 & -.100 & -.098 \\
\hline Age (SA) & -.018 & -.044 & -.0200 & -.039 & .096 & .125 \\
\hline $\begin{array}{l}\text { Adjusted } \\
\text { Gross Income } \\
\text { (SAGI) }\end{array}$ & .009 & -.005 & -.008 & -.012 & .067 & .067 \\
\hline White (R1) & .001 & .016 & .021 & .040 & -.053 & -.048 \\
\hline $\begin{array}{l}\text { Black or } \\
\text { African } \\
\text { American } \\
\text { (R2) }\end{array}$ & .004 & .015 & -.011 & -.003 & -.055 & -0.050 \\
\hline $\begin{array}{l}\text { Hispanic or } \\
\text { Latino (R3) }\end{array}$ & -.014 & -.023 & -.005 & -.019 & -.009 & -.009 \\
\hline Asian (R4) & -.014 & -.008 & $\begin{array}{l}-.009 \\
\end{array}$ & -.021 & .006 & .009 \\
\hline Other (R5) & -.025 & -.035 & -.037 & -.028 & -.077 & -.059 \\
\hline $\begin{array}{l}\text { Do not know } \\
\text { parent's } \\
\text { education } \\
\text { level (SPEL1) }\end{array}$ & $\begin{array}{l}-.039 \\
\end{array}$ & -.054 & -.056 & -.044 & -.118 & -.090 \\
\hline $\begin{array}{l}\text { Did not } \\
\text { complete high } \\
\text { school } \\
\text { (SPEL2) }\end{array}$ & -.104 & -.145 & -.150 & -.116 & -.316 & -.241 \\
\hline $\begin{array}{l}\text { High school } \\
\text { diploma or } \\
\text { equivalent } \\
\text { (SPEL3) }\end{array}$ & 1 & -.053 & -.055 & -.043 & -.116 & -.088 \\
\hline $\begin{array}{l}\text { Vocational or } \\
\text { technical } \\
\text { training } \\
\text { (SPEL4) } \\
\end{array}$ & -.053 & 1 & -.077 & $\begin{array}{l}.059 \\
\end{array}$ & -.161 & -.123 \\
\hline $\begin{array}{l}\text { Less than two } \\
\text { years of } \\
\text { college }\end{array}$ & -.055 & -.077 & 1 & -.061 & -.167 & -.127 \\
\hline
\end{tabular}




\begin{tabular}{|c|c|c|c|c|c|c|}
\hline \multicolumn{7}{|l|}{ (SPEL5) } \\
\hline $\begin{array}{l}\text { Associate's } \\
\text { degree } \\
\text { (SPEL6) }\end{array}$ & -.043 & -.059 & -.061 & 1 & -.129 & -.098 \\
\hline $\begin{array}{l}2 \text { or more } \\
\text { years of } \\
\text { college but no } \\
\text { degree } \\
\text { (SPEL7) }\end{array}$ & -.116 & -.161 & -.167 & -.129 & 1 & -.267 \\
\hline $\begin{array}{l}\text { Bachelor's } \\
\text { degree } \\
\text { (SPEL8) }\end{array}$ & -.088 & -.123 & -.127 & -.098 & -.267 & 1 \\
\hline $\begin{array}{l}\text { Master's } \\
\text { degree or } \\
\text { equivalent } \\
\text { (SPEL9) }\end{array}$ & -.032 & -.044 & -.046 & -.035 & -.096 & $\begin{array}{l}.073 \\
\end{array}$ \\
\hline $\begin{array}{l}\text { First- } \\
\text { professional } \\
\text { degree } \\
\text { (SPEL10) }\end{array}$ & .025 & -.018 & -.008 & -.006 & .005 & .037 \\
\hline $\begin{array}{l}\text { Grade point } \\
\text { average } \\
\text { (SGPA) }\end{array}$ & -.012 & -.004 & -.009 & .001 & .034 & .030 \\
\hline $\begin{array}{l}\text { Veteran Status } \\
\text { (SVA) }\end{array}$ & .002 & 0.030 & .020 & .023 & -.030 & -.049 \\
\hline $\begin{array}{l}\text { Attend } \\
\text { institution in } \\
\text { state of legal } \\
\text { residence } \\
=\text { Yes (LOC1) }\end{array}$ & -.011 & -.023 & -.019 & -.017 & .028 & .055 \\
\hline $\begin{array}{l}\text { Attend } \\
\text { institution in } \\
\text { state of legal } \\
\text { residence=No } \\
\text { (LOC2) }\end{array}$ & & & & & & \\
\hline
\end{tabular}

Table 89: Equation 7a correlations (continued)

\begin{tabular}{|l|l|l|l|l|l|}
\hline & $\begin{array}{l}\text { First- } \\
\text { professional } \\
\text { degree }\end{array}$ & $\begin{array}{l}\text { Grade } \\
\text { point } \\
\text { average }\end{array}$ & $\begin{array}{l}\text { Veteran } \\
\text { Status }\end{array}$ & $\begin{array}{l}\text { Attend } \\
\text { institution } \\
\text { in state of } \\
\text { legal } \\
\text { residence }\end{array}$ & $\begin{array}{l}\text { Attend institution } \\
\text { in state of legal } \\
\text { residence=No }\end{array}$ \\
\hline
\end{tabular}




\begin{tabular}{|c|c|c|c|c|c|}
\hline & & & & $=$ Yes & \\
\hline $\begin{array}{l}\text { Total federal } \\
\text { grants, } \\
\text { veteran, and } \\
\text { tax benefits } \\
\text { (FFPB) }\end{array}$ & -.035 & -.057 & -.176 & .017 & .007 \\
\hline $\begin{array}{l}\text { Tuition and } \\
\text { Fees (T) }\end{array}$ & .041 & .063 & .056 & -.559 & .524 \\
\hline Age (SA) & -.033 & .133 & -.202 & .095 & -.097 \\
\hline $\begin{array}{l}\text { Adjusted } \\
\text { Gross Income } \\
\text { (SAGI) }\end{array}$ & .058 & .048 & .056 & -.077 & .099 \\
\hline White (R1) & .015 & .121 & .011 & .028 & .025 \\
\hline $\begin{array}{l}\text { Black or } \\
\text { African } \\
\text { American } \\
\text { (R2) }\end{array}$ & -.0200 & -.132 & -.021 & -.039 & .033 \\
\hline $\begin{array}{l}\text { Hispanic or } \\
\text { Latino (R3) }\end{array}$ & -.015 & -.054 & .007 & .043 & -.048 \\
\hline Asian (R4) & .011 & .016 & .012 & -.064 & -.020 \\
\hline Other (R5) & .001 & $\begin{array}{l}.009 \\
-.09\end{array}$ & -.021 & .014 & -.021 \\
\hline $\begin{array}{l}\text { Do not know } \\
\text { parent's } \\
\text { education } \\
\text { level (SPEL1) }\end{array}$ & -.021 & -.027 & -.038 & .010 & -.019 \\
\hline $\begin{array}{l}\text { Did not } \\
\text { complete high } \\
\text { school } \\
\text { (SPEL2) }\end{array}$ & -.032 & -.004 & -.014 & .032 & -.035 \\
\hline $\begin{array}{l}\text { High school } \\
\text { diploma or } \\
\text { equivalent } \\
\text { (SPEL3) } \\
\end{array}$ & -.086 & -.045 & -.039 & .040 & -.039 \\
\hline $\begin{array}{l}\text { Vocational or } \\
\text { technical } \\
\text { training } \\
\text { (SPEL4) }\end{array}$ & -.032 & .025 & -.012 & .002 & -.011 \\
\hline $\begin{array}{l}\text { Less than two } \\
\text { years of } \\
\text { college }\end{array}$ & -.044 & -.018 & -.004 & .030 & -.023 \\
\hline
\end{tabular}




\begin{tabular}{|c|c|c|c|c|c|}
\hline \multicolumn{6}{|l|}{ (SPEL5) } \\
\hline \multicolumn{6}{|l|}{$\begin{array}{l}\text { Associate's } \\
\text { degree } \\
\text { (SPEL6) }\end{array}$} \\
\hline $\begin{array}{l}2 \text { or more } \\
\text { years of } \\
\text { college but no } \\
\text { degree } \\
\text { (SPEL7) }\end{array}$ & -.035 & -.006 & .001 & .023 & -.017 \\
\hline $\begin{array}{l}\text { Bachelor's } \\
\text { degree } \\
\text { (SPEL8) }\end{array}$ & -.096 & .005 & .034 & -.030 & .028 \\
\hline $\begin{array}{l}\text { Master's } \\
\text { degree or } \\
\text { equivalent } \\
\text { (SPEL9) }\end{array}$ & -.073 & .037 & .030 & -.049 & .055 \\
\hline $\begin{array}{l}\text { First- } \\
\text { professional } \\
\text { degree } \\
\text { (SPEL10) }\end{array}$ & 1 & .033 & .002 & -.019 & .017 \\
\hline $\begin{array}{l}\text { Grade point } \\
\text { average } \\
\text { (SGPA) }\end{array}$ & .033 & 1 & -.027 & -.023 & .008 \\
\hline $\begin{array}{l}\text { Veteran Status } \\
\text { (SVA) }\end{array}$ & .002 & -.027 & 1 & -.027 & .021 \\
\hline $\begin{array}{l}\text { Attend } \\
\text { institution in } \\
\text { state of legal } \\
\text { residence } \\
=\text { Yes (LOC1) }\end{array}$ & -.019 & -.023 & -.027 & 1 & -.906 \\
\hline $\begin{array}{l}\text { Attend } \\
\text { institution in } \\
\text { state of legal } \\
\text { residence=No } \\
\text { (LOC2) }\end{array}$ & .017 & .008 & .021 & -.906 & 1 \\
\hline
\end{tabular}

This analysis shows that significant relationships exist between the amount of federal financial grant aid received per student at public institutions and tuition and fees, students ages, adjusted gross incomes; their classifications as Black or African Americans, In addition relationships were noted between the dependent variable and the education levels of parents 
whose educational level were unknown; did not complete high school; received a high school diploma or equivalent; received vocational or technical training; had less than two years of college; held Associate's degree; had two years of college but no degree; and had Bachelor's degrees. A relationship is indicated between the dependent variable and students' statuses as veterans. The analysis also indicates that a relationship exists between the dependent variable and students' statuses as residents in the state within which the institutions are located and students' statuses as non-residents of the state within which the institutions are located. These relationships are represented by the following econometric equation:

$\mathrm{FFPB}_{\mathrm{i}}=0.106 \mathrm{~T}_{\mathrm{i}}+-20.688 \mathrm{SA}_{\mathrm{i}}+-0.013 \mathrm{SAGI}+309.399 \mathrm{SR} 2+628.891 \mathrm{SPEL} 1$

+727.771SPEL2 +389.839SPEL3 + 261.529SPEL4 + 436.044SPEL5 + 236.769SPEL6 + 363.316SPEL 7 + 164.54SPEL 8 - 0.539SGPA -2147.721SVA + 1396.081LOC1 + 992.099LOC $2+2630.273$

Research Question 7b: Is there a relationship between the amount of federal grants, veteran and tax benefits received per student, the amount of tuition and fees paid per student, student characteristics, and the economic and political characteristics of the states? Research Question $7 \mathrm{~b}$ relates to Hypothesis $\left(\mathrm{H}_{7 \mathrm{~b}}\right)$, that there is no significant relationship between the amount of federal grants, veteran, and tax benefits received per student by private institutions, the amount of tuition and fees per student charged to in-state students, student characteristics, and the economic and political characteristics of the states. As described in Chapter 3, Equation 7b1 relates to Research Question 7b and Hypothesis 7b:

$$
\mathrm{FFPV}_{\mathrm{i}}=\mathrm{T}_{\mathrm{i}}+\mathrm{SA}_{\mathrm{i}}+\mathrm{SAGI}_{\mathrm{i}}+\mathrm{SR}_{\mathrm{i}}+\mathrm{SG}_{\mathrm{i}}+\mathrm{SPEL}_{\mathrm{i}}+\mathrm{SGPA}_{\mathrm{i}}+\mathrm{SVA}_{\mathrm{i}}+\mathrm{LOC}_{\mathrm{i}}
$$


The significance scores for this equation are displayed in Table 90. The NCES' DAS was used to perform a weighted least squares computation using NPSAS: 04 data.

Table 90: Equation $7 \mathrm{~b}$ hypothesis testing results

\begin{tabular}{|l|r|r|r|r|r|}
\hline & Wald $F$ & $\begin{array}{l}\text { Num. } \\
\text { DF }\end{array}$ & $\begin{array}{l}\text { Denom. } \\
\text { DF }\end{array}$ & Commonality & $\begin{array}{l}\text { Probability } \\
F\end{array}$ \\
\hline Overall Fit & 49.232 & 23 & 42 & & .001 \\
\hline Tuition and fees (T) & 72.882 & 1 & 64 & .025 & .001 \\
\hline Age (SA) & 35.359 & 1 & 64 & .005 & .001 \\
\hline $\begin{array}{l}\text { Adjusted Gross Income } \\
\text { (AGI) }\end{array}$ & 554.663 & 1 & 64 & .115 & .001 \\
\hline Race (SR) & 1.406 & 5 & 60 & .002 & .235 \\
\hline Gender (SG) & 5.696 & 1 & 64 & .001 & .020 \\
\hline $\begin{array}{l}\text { Parent's highest } \\
\text { education level (SPEL) }\end{array}$ & 8.521 & 10 & 55 & .009 & .001 \\
\hline $\begin{array}{l}\text { Grade point average } \\
\text { (SGPA) }\end{array}$ & 1.911 & 1 & 64 & 0 & .172 \\
\hline Veteran status (SVA) & 9.953 & 1 & 64 & .010 & .002 \\
\hline $\begin{array}{l}\text { Attend institution in } \\
\text { state of legal residence } \\
\text { (LOC) }\end{array}$ & 85.001 & 2 & 63 & .009 & .001 \\
\hline
\end{tabular}

All the variables in this equation were significant except for Race (SR) and Grade point average (SGPA). A second equation was computed without these variables. The significance scores are displayed in Table 91. All of the variables were significant for these equations. The coefficient of determination was .184. From this statistic, we may conclude that 18.4 percent of the variance in federal financial grant aid per student paid by public institutions is explained by the independent variables in this equation. The regression coefficients for this equation are shown in Table 92. The coefficient for the variable First professional degree was not significant.

Table 91: Equation 7b hypothesis testing results second calculation

\begin{tabular}{|l|r|r|r|r|r|}
\hline & Wald $F$ & $\begin{array}{l}\text { Num. } \\
\text { DF }\end{array}$ & $\begin{array}{l}\text { Denom. } \\
\text { DF }\end{array}$ & Commonality & \multicolumn{2}{l|}{$\begin{array}{l}\text { Probability } \\
F\end{array}$} \\
\hline Overall Fit & 65.538 & 17 & 48 & & .001 \\
\hline Tuition and fees (T) & 70.071 & 1 & 64 & .025 & .001 \\
\hline
\end{tabular}




\begin{tabular}{|l|r|r|r|r|r|}
\hline Age (SA) & 36.431 & 1 & 64 & .006 & .001 \\
\hline $\begin{array}{l}\text { Adjusted Gross Income } \\
\text { (SAGI) }\end{array}$ & 666.635 & 1 & 64 & .124 & .001 \\
\hline Gender (SG) & 6.209 & 1 & 64 & .001 & .015 \\
\hline $\begin{array}{l}\text { Parent's highest } \\
\text { education level (SPEL) }\end{array}$ & 8.690 & 10 & 55 & .010 & .001 \\
\hline Veteran status (SVA) & 10.346 & 1 & 64 & .010 & .002 \\
\hline $\begin{array}{l}\text { Attend institution in } \\
\text { state of legal residence } \\
\text { (LOC) }\end{array}$ & 84.075 & 2 & 63 & .008 & .001 \\
\hline
\end{tabular}

Table 92: Equation 7b estimated full sample regression coefficients

\begin{tabular}{|c|c|c|c|c|}
\hline & $\mathrm{B}$ & s.e. & $t$ & Probability $t$ \\
\hline Intercept & 1729.01 & 422.846 & 4.089 & .001 \\
\hline Tuition and fees (T) & .040 & .005 & 8.371 & .001 \\
\hline Age (SA) & -20.132 & 3.335 & -6.036 & .001 \\
\hline Adjusted Gross Income (SAGI) & -.014 & .001 & -25.819 & .001 \\
\hline \multicolumn{5}{|l|}{ Gender } \\
\hline Male (SG) & 101.713 & 40.821 & 2.492 & .015 \\
\hline \multicolumn{5}{|l|}{ vs. Female } \\
\hline \multicolumn{5}{|l|}{ Parent's highest education level } \\
\hline $\begin{array}{l}\text { Do not know parent's education level } \\
\text { (SPEL1) }\end{array}$ & 831.252 & 212.499 & 3.912 & .001 \\
\hline $\begin{array}{l}\text { Did not complete high school } \\
\text { (SPEL2) }\end{array}$ & 778.059 & 143.434 & 5.425 & .001 \\
\hline $\begin{array}{l}\text { High school diploma or equivalent } \\
\text { (SPEL3) }\end{array}$ & 610.147 & 83.214 & 7.332 & .001 \\
\hline $\begin{array}{l}\text { Vocational or technical training } \\
\text { (SPEL4) }\end{array}$ & 428.499 & 117.578 & 3.644 & .001 \\
\hline $\begin{array}{l}\text { Less than two years of college } \\
\text { (SPEL5) }\end{array}$ & 635.071 & 115.492 & 5.499 & .001 \\
\hline Associate's degree (SPEL6) & 467.883 & 113.258 & 4.131 & .001 \\
\hline $\begin{array}{l}2 \text { or more years of college but no } \\
\text { degree (SPEL7) }\end{array}$ & 538.511 & 94.219 & 5.716 & .001 \\
\hline Bachelor's degree (SPEL8) & 347.580 & 76.412 & 4.549 & .001 \\
\hline $\begin{array}{l}\text { Master's degree or equivalent } \\
\text { (SPEL9) }\end{array}$ & 221.243 & 66.488 & 3.328 & .001 \\
\hline First-professional degree (SPEL10) & -45.333 & 154.839 & -0.293 & .771 \\
\hline \multicolumn{5}{|l|}{ vs. Doctoral degree or equivalent } \\
\hline \multicolumn{5}{|l|}{ Veteran status } \\
\hline Not a veteran (SVA) & -1161.200 & 361.023 & -3.216 & .002 \\
\hline \multicolumn{5}{|l|}{ vs. Veteran } \\
\hline Attend institution in state of legal & & & & \\
\hline
\end{tabular}




\begin{tabular}{|l|l|l|l|l|}
\hline residence & & & & \\
\hline Yes (LOC1) & 1159.450 & 90.879 & 12.758 & .001 \\
\hline No (LOC2) & 1061.480 & 88.223 & 12.032 & .001 \\
\hline vs. Foreign or international student & & & & \\
\hline
\end{tabular}

The correlations for this equation are displayed in Table 93.

Table 93 Equation 7b correlations

\begin{tabular}{|c|c|c|c|c|c|c|}
\hline & $\begin{array}{l}\text { Total } \\
\text { federal } \\
\text { grants, } \\
\text { veteran, } \\
\text { and tax } \\
\text { benefits }\end{array}$ & $\begin{array}{l}\text { Tuition } \\
\text { and fees }\end{array}$ & Age & $\begin{array}{l}\text { Adjusted } \\
\text { Gross } \\
\text { Income } \\
\text { (AGI) }\end{array}$ & Gender & $\begin{array}{l}\text { Do not } \\
\text { know } \\
\text { parent's } \\
\text { education } \\
\text { level }\end{array}$ \\
\hline $\begin{array}{l}\text { Total federal } \\
\text { grants, } \\
\text { veteran, and } \\
\text { tax benefits } \\
\text { (FFPV) }\end{array}$ & 1 & .069 & -.051 & -.348 & .028 & .043 \\
\hline $\begin{array}{l}\text { Tuition and } \\
\text { fees }(\mathrm{T})\end{array}$ & .069 & 1 & -.500 & .278 & .041 & -.057 \\
\hline Age (SA) & -.051 & -.500 & 1 & -.177 & -.053 & .075 \\
\hline $\begin{array}{l}\text { Adjusted } \\
\text { Gross } \\
\text { Income } \\
\text { (SAGI) }\end{array}$ & -.348 & .278 & -.177 & 1 & .027 & -.073 \\
\hline Gender (SG) & .028 & .041 & -.053 & .027 & 1 & -.011 \\
\hline $\begin{array}{l}\text { Do not } \\
\text { know } \\
\text { parent's } \\
\text { education } \\
\text { level } \\
\text { (SPEL1) }\end{array}$ & .043 & -.057 & .075 & $\begin{array}{l}.073 \\
\end{array}$ & -.011 & 1 \\
\hline $\begin{array}{l}\text { Did not } \\
\text { complete } \\
\text { high school } \\
\text { (SPEL2) }\end{array}$ & .043 & -.118 & .216 & -.100 & -.044 & -.027 \\
\hline $\begin{array}{l}\text { High school } \\
\text { diploma or } \\
\text { equivalent } \\
\text { (SPEL3) }\end{array}$ & .071 & -.212 & .209 & -.167 & -.025 & -.069 \\
\hline
\end{tabular}




\begin{tabular}{|c|c|c|c|c|c|c|}
\hline $\begin{array}{l}\text { Vocational } \\
\text { or technical } \\
\text { training } \\
\text { (SPEL4) }\end{array}$ & .015 & -.024 & .038 & -.056 & -.005 & -.024 \\
\hline $\begin{array}{l}\text { Less than } \\
\text { two years of } \\
\text { college } \\
\text { (SPEL5) }\end{array}$ & .044 & -.030 & -.002 & -.045 & -.026 & -.032 \\
\hline $\begin{array}{l}\text { Associate's } \\
\text { degree } \\
\text { (SPEL6) }\end{array}$ & .020 & -.039 & .003 & -.035 & .023 & -.035 \\
\hline $\begin{array}{l}2 \text { or more } \\
\text { years of } \\
\text { college but } \\
\text { no degree } \\
\text { (SPEL7) }\end{array}$ & .025 & -.049 & .012 & -.048 & -.013 & -.028 \\
\hline $\begin{array}{l}\text { Bachelor's } \\
\text { degree } \\
\text { (SPEL8) }\end{array}$ & -.016 & .078 & -.121 & .048 & .021 & -.073 \\
\hline $\begin{array}{l}\text { Master's } \\
\text { degree or } \\
\text { equivalent } \\
\text { (SPEL9) }\end{array}$ & -.0700 & .146 & -.149 & .153 & .025 & -.061 \\
\hline $\begin{array}{l}\text { First- } \\
\text { professional } \\
\text { degree } \\
\text { (SPEL10) } \\
\end{array}$ & -.061 & .127 & -.091 & .104 & .006 & -.026 \\
\hline $\begin{array}{l}\text { Not a } \\
\text { veteran } \\
\text { (SVA) } \\
\end{array}$ & -.080 & .160 & -.246 & .030 & -.126 & -.022 \\
\hline $\begin{array}{l}\text { Attend } \\
\text { institution in } \\
\text { state of legal } \\
\text { residence } \\
\text { =Yes } \\
\text { (LOC1) }\end{array}$ & .066 & -.261 & $\begin{array}{l}.218 \\
\end{array}$ & -.175 & $\begin{array}{l}.080 \\
\end{array}$ & .040 \\
\hline $\begin{array}{l}\text { Attend } \\
\text { institution in } \\
\text { state of legal } \\
\text { residence } \\
=\text { No } \\
\text { (LOC2) } \\
\end{array}$ & -.045 & .255 & -.208 & .195 & .062 & -.036 \\
\hline
\end{tabular}


Table 93: Equation 7b correlations (continued)

\begin{tabular}{|c|c|c|c|c|c|c|}
\hline & $\begin{array}{l}\text { Did not } \\
\text { complete } \\
\text { high } \\
\text { school }\end{array}$ & $\begin{array}{l}\text { High } \\
\text { school } \\
\text { diploma } \\
\text { or } \\
\text { equivalent }\end{array}$ & $\begin{array}{l}\text { Vocational } \\
\text { or technical } \\
\text { training }\end{array}$ & $\begin{array}{l}\text { Less } \\
\text { than two } \\
\text { years of } \\
\text { college }\end{array}$ & $\begin{array}{l}\text { Associate's } \\
\text { degree }\end{array}$ & $\begin{array}{l}2 \text { or } \\
\text { more } \\
\text { years of } \\
\text { college } \\
\text { but no } \\
\text { degree } \\
\end{array}$ \\
\hline $\begin{array}{l}\text { Total federal } \\
\text { grants, } \\
\text { veteran, and } \\
\text { tax benefits } \\
\text { (FFPV) }\end{array}$ & .043 & .071 & .015 & .044 & .020 & .025 \\
\hline $\begin{array}{l}\text { Tuition and } \\
\text { fees }(T)\end{array}$ & -.118 & -.212 & -.024 & -.030 & -.039 & -.049 \\
\hline Age (SA) & .216 & .209 & .038 & -.002 & .003 & .012 \\
\hline $\begin{array}{l}\text { Adjusted } \\
\text { Gross } \\
\text { Income } \\
\text { (SAGI) }\end{array}$ & -.100 & -.167 & -.056 & -.045 & -.035 & -.048 \\
\hline Gender (SG) & -.044 & -.025 & -.005 & -.026 & .023 & -.013 \\
\hline $\begin{array}{l}\text { Do not } \\
\text { know } \\
\text { parent's } \\
\text { education } \\
\text { level } \\
\text { (SPEL1) } \\
\end{array}$ & -.027 & -.069 & -.024 & -.032 & -.035 & -.028 \\
\hline $\begin{array}{l}\text { Did not } \\
\text { complete } \\
\text { high school } \\
\text { (SPEL2) }\end{array}$ & 1 & -.110 & -.039 & -.051 & -.055 & -.044 \\
\hline $\begin{array}{l}\text { High school } \\
\text { diploma or } \\
\text { equivalent } \\
\text { (SPEL3) }\end{array}$ & -.110 & 1 & -.100 & -.130 & -.142 & -.113 \\
\hline $\begin{array}{l}\text { Vocational } \\
\text { or technical } \\
\text { training } \\
\text { (SPEL4) }\end{array}$ & $\begin{array}{l}.039 \\
\end{array}$ & -.100 & 1 & -.046 & -.0500 & -.040 \\
\hline $\begin{array}{l}\text { Less than } \\
\text { two years of } \\
\text { college } \\
\text { (SPEL5) }\end{array}$ & -.051 & -.130 & -.046 & 1 & -.065 & -.052 \\
\hline
\end{tabular}




\begin{tabular}{|l|c|c|c|c|c|c|}
\hline $\begin{array}{l}\text { Associate's } \\
\text { degree } \\
\text { (SPEL6) }\end{array}$ & -.055 & -.142 & -.050 & -.065 & & -.057 \\
\hline $\begin{array}{l}\text { 2 or more } \\
\text { years of } \\
\text { college but } \\
\text { no degree } \\
\text { (SPEL7) }\end{array}$ & -.044 & -.113 & -.040 & -.052 & -.057 & 1 \\
\hline $\begin{array}{l}\text { Bachelor's } \\
\text { degree } \\
\text { (SPEL8) }\end{array}$ & -.116 & -.297 & -.104 & -.137 & -.149 & -.118 \\
\hline $\begin{array}{l}\text { Master's } \\
\text { degree or } \\
\text { equivalent } \\
\text { (SPEL9) }\end{array}$ & -.100 & -.250 & -.088 & -.115 & -.125 & -.099 \\
\hline $\begin{array}{l}\text { First- } \\
\text { professional } \\
\text { degree } \\
\text { (SPEL10) }\end{array}$ & -.041 & -.106 & -.037 & -.049 & -.053 & -.042 \\
\hline $\begin{array}{l}\text { Not a } \\
\text { veteran } \\
\text { (SVA) }\end{array}$ & -.061 & -.061 & .011 & -.011 & -.028 & -.012 \\
\hline $\begin{array}{l}\text { Attend } \\
\text { institution in } \\
\text { state of legal } \\
\text { residence } \\
\text { =Yes } \\
\text { (LOC1) }\end{array}$ & .075 & .107 & .031 & .041 & .034 & .022 \\
\hline $\begin{array}{l}\text { Attend } \\
\text { institution in } \\
\text { state of legal } \\
\text { residence } \\
\text { =No } \\
\text { (LOC2) }\end{array}$ & -.073 & -.103 & -.032 & -.035 & -.031 & -.018 \\
\hline
\end{tabular}

Table 93: Equation 7b correlations (continued)

\begin{tabular}{|l|l|l|l|l|l|l|}
\hline & $\begin{array}{l}\text { Bachelor's } \\
\text { degree }\end{array}$ & $\begin{array}{l}\text { Master's } \\
\text { degree or } \\
\text { equivalent }\end{array}$ & $\begin{array}{l}\text { First- } \\
\text { professional } \\
\text { degree }\end{array}$ & $\begin{array}{l}\text { Not a } \\
\text { veteran }\end{array}$ & $\begin{array}{l}\text { Attend } \\
\text { institution } \\
\text { in state of } \\
\text { legal } \\
\text { residence } \\
=\text { Yes }\end{array}$ & $\begin{array}{l}\text { Attend } \\
\text { institution } \\
\text { in state of } \\
\text { legal } \\
\text { residence } \\
\text { =No }\end{array}$ \\
\hline
\end{tabular}




\begin{tabular}{|c|c|c|c|c|c|c|}
\hline $\begin{array}{l}\text { Total federal } \\
\text { grants, } \\
\text { veteran, and } \\
\text { tax benefits } \\
\text { (FFPV) }\end{array}$ & -.016 & -.070 & -.061 & -.080 & .066 & -.045 \\
\hline $\begin{array}{l}\text { Tuition and } \\
\text { fees }(\mathrm{T})\end{array}$ & .078 & .146 & .127 & .160 & -.261 & .255 \\
\hline Age (SA) & -.121 & -.149 & -.091 & -.246 & .218 & -.208 \\
\hline $\begin{array}{l}\text { Adjusted } \\
\text { Gross } \\
\text { Income } \\
\text { (SAGI) }\end{array}$ & .048 & .153 & .104 & .030 & -.175 & .195 \\
\hline Gender (SG) & .021 & .025 & .006 & -.126 & -.080 & .062 \\
\hline $\begin{array}{l}\text { Do not } \\
\text { know } \\
\text { parent's } \\
\text { education } \\
\text { level } \\
\text { (SPEL1) }\end{array}$ & -.073 & -.061 & -.026 & -.022 & .040 & -.036 \\
\hline $\begin{array}{l}\text { Did not } \\
\text { complete } \\
\text { high school } \\
\text { (SPEL2) }\end{array}$ & -.116 & -.097 & -.041 & -.061 & .075 & -.073 \\
\hline $\begin{array}{l}\text { High school } \\
\text { diploma or } \\
\text { equivalent } \\
\text { (SPEL3) }\end{array}$ & -.297 & -.250 & -.106 & -.061 & .107 & -.103 \\
\hline $\begin{array}{l}\text { Vocational } \\
\text { or technical } \\
\text { training } \\
\text { (SPEL4) } \\
\end{array}$ & -.104 & -.088 & -.037 & .011 & .031 & -.032 \\
\hline $\begin{array}{l}\text { Less than } \\
\text { two years of } \\
\text { college } \\
\text { (SPEL5) } \\
\end{array}$ & -.137 & -.115 & -.049 & -.011 & .041 & -.035 \\
\hline $\begin{array}{l}\text { Associate's } \\
\text { degree } \\
\text { (SPEL6) } \\
\end{array}$ & -.149 & -.125 & -.053 & -.028 & .034 & -.031 \\
\hline $\begin{array}{l}2 \text { or more } \\
\text { years of } \\
\text { college but } \\
\text { no degree } \\
\text { (SPEL7) } \\
\end{array}$ & -.118 & -.099 & -.042 & -.012 & .022 & -.018 \\
\hline $\begin{array}{l}\text { Bachelor's } \\
\text { degree }\end{array}$ & 1 & -.263 & -.112 & .044 & -.052 & .046 \\
\hline
\end{tabular}




\begin{tabular}{|l|r|r|r|r|r|r|}
\hline (SPEL8) & & & & & & \\
\hline $\begin{array}{l}\text { Master's } \\
\text { degree or } \\
\text { equivalent } \\
\text { (SPEL9) }\end{array}$ & -.263 & 1 & -.094 & .044 & -.092 & .087 \\
\hline $\begin{array}{l}\text { First- } \\
\text { professional } \\
\text { degree } \\
\text { (SPEL10) }\end{array}$ & -.112 & -.094 & 1 & .030 & -.096 & .090 \\
\hline $\begin{array}{l}\text { Not a } \\
\text { veteran } \\
\text { (SVA) }\end{array}$ & .044 & .044 & .0300 & 1 & -.055 & .047 \\
\hline $\begin{array}{l}\text { Attend } \\
\text { institution in } \\
\text { state of legal } \\
\text { residence } \\
\text { =Yes } \\
\text { (LOC1) }\end{array}$ & -.052 & -.092 & -.096 & -.055 & & 1 \\
\hline $\begin{array}{l}\text { Attend } \\
\text { institution in } \\
\text { state of legal } \\
\text { residence } \\
\text { =No } \\
\text { (LOC2) }\end{array}$ & .046 & .087 & .090 & .047 & -.947 & -.947 \\
\hline
\end{tabular}

This analysis shows that significant relationships exist between the amount of federal financial grant aid received per student at private institutions and tuition and fees, students' ages, adjusted gross incomes and students' statuses as males. In addition relationships were noted between the dependent variable and the education levels of parents whose educational level were unknown; did not complete high school; received a high school diploma or equivalent; received vocational or technical training; had less than two years of college; held Associate's degree; had two years of college but no degree; received Bachelor's degrees and had Master's degrees or equivalent. A relationship is indicated between the dependent variable and students' statuses as veterans. The analysis also indicates that a relationship exists between the dependent variable and students' statuses as residents in the state within which the institutions are located and 
students' statuses as non-residents of the state within which the institutions are located. These relationships are represented by the following econometric equation:

$$
\text { FFPV }_{\mathrm{i}}=.04 \mathrm{~T}-20.132 \mathrm{SA}_{\mathrm{i}}-.014 \mathrm{SAGI}+101.713 \mathrm{SG}+831.252 \mathrm{SPEL} 1+778.059 \mathrm{SPEL} 2+
$$

610.147SPEL3 + 428.499SPEL4 +635.071SPEL5 + 467.883SPEL6 + 538.511SPEL7 +

347.58SPEL8 + 221.243SPEL9 -1161.2SVA + 1159.45LOC1 + 1061.48LOC2 + 1729.01

Research Question 7c: Does the amount of federal grants, veterans and tax benefits received per student at public institutions differ from the amount of federal grant, veterans and tax benefits received per student at private institutions? Research Question $7 \mathrm{c}$ relates to Hypothesis $\left(\mathrm{H}_{7 \mathrm{c}}\right)$, that the amount of federal grants, veterans and tax benefits received per student at public institutions was less than or equal to the amount of federal grants, veterans and tax benefits per student received at private institutions.

As described in Chapter 3, Equation 7c relates to Research Question 7c and Hypothesis $7 \mathrm{c}:$

$\mathrm{FFPB} \leq \mathrm{FFPV}$

The data used for the means comparison are displayed in Table 94. The following formula was used to calculate the $t$ value:

$$
t_{d f}=\frac{\left|\bar{x}_{A}-\bar{x}_{B}\right|}{\sqrt{\hat{V}_{A}+\hat{V}_{B}}}
$$

The means for the two groups that were compared are represented by $\bar{x}_{A}$ and $\bar{x}_{B}$. The respective squared standard errors associated with the means are represented by $\hat{V}_{A}$ and $\hat{V}_{B}$. 
The $t$ value for the comparison of the two means was 22.43. Because the test statistic exceeds the critical value of \pm 1.96 , the difference between the two means is statistically significant.

Table 94: Equation 7c group statistics

\begin{tabular}{|l|r|r|}
\hline & Mean & Standard Error \\
\hline Public Institutions & 957.568 & 8.157 \\
\hline Private Institutions & 1452.119 & 20.483 \\
\hline
\end{tabular}

\section{Research Question 8a: Is there a relationship between Tuition and fees minus all} grants, veteran, and tax benefits for in-state students enrolled at public institutions and adjusted gross income? Research Question 8a relates to Hypothesis $\left(\mathrm{H}_{8 \mathrm{a}}\right)$, that there is no significant relationship between tuition and fees minus all grants, veteran, and tax benefits for instate students enrolled at public institutions and adjusted gross income. As described in Chapter 3, Equation 8a relates to Research Question 8a and Hypothesis 8a:

$$
\mathrm{TGVTBPBI}_{\mathrm{i}}=\mathrm{AGI}_{\mathrm{i}}
$$

The significance scores for this equation are displayed in Table 95. The NCES' DAS was used to perform a weighted least squares computation using NPSAS: 04 data. Both of the variables for this equation were significant. The coefficient of determination was .0737 . From this statistic, we may conclude that 7.37 percent of the variance in amount of tax benefit received from federal tax credits and deductions per student enrolled in private institutions is explained by the independent variables in this equation. The regression coefficients for this equation are displayed in Table 96.

Table 95: Equation 8a hypothesis testing results

\begin{tabular}{|c|c|c|c|c|c|}
\hline 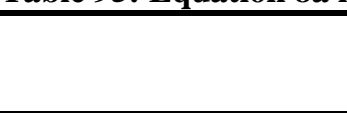 & Wald $F$ & $\begin{array}{l}\text { Num. } \\
\text { DF }\end{array}$ & $\begin{array}{l}\text { Denom. } \\
\text { DF }\end{array}$ & Commonality & $\begin{array}{l}\text { Probability } \\
\text { F }\end{array}$ \\
\hline Overall Fit & 415.661 & 1 & 64 & & .001 \\
\hline
\end{tabular}




\begin{tabular}{|l|l|l|l|l|l|}
\hline $\begin{array}{l}\text { Adjusted Gross } \\
\text { Income (SAGI) }\end{array}$ & 415.661 & 1 & 64 & .074 & .001 \\
\hline
\end{tabular}

Table 96: Equation 8a estimated full sample regression coefficients

\begin{tabular}{|l|r|r|r|r|}
\hline & B & s.e. & \multicolumn{1}{|l|}{$t$} & \multicolumn{2}{|c|}{ Probability $t$} \\
\hline Intercept & 1920.372 & 54.120 & 35.483 & .001 \\
\hline $\begin{array}{l}\text { Adjusted Gross } \\
\text { Income (SAGI) }\end{array}$ & .011 & .001 & 20.388 & .001 \\
\hline
\end{tabular}

The correlation for this equation is displayed in Table 97.

Table 97: Equation 8a correlation

\begin{tabular}{|l|r|r|}
\hline & $\begin{array}{r}\text { Tuition and fees } \\
\text { minus all grants, } \\
\text { veteran, and tax } \\
\text { benefits } \\
\text { (TGVTBPBI) }\end{array}$ & $\begin{array}{r}\text { Adjusted } \\
\text { Gross } \\
\text { Income } \\
\text { (SAGI) }\end{array}$ \\
\hline $\begin{array}{l}\text { Tuition and fees } \\
\text { minus all grants, } \\
\text { veteran, and tax } \\
\text { benefits } \\
\text { (TGVTBPBI) }\end{array}$ & 1 & 0.271 \\
\hline $\begin{array}{l}\text { Adjusted Gross } \\
\text { Income (SAGI) }\end{array}$ & & \\
\hline
\end{tabular}

The relationship between the amount of institutional need-based financial grant aid paid per student by public institutions and related market variables is represented by the following econometric equation:

TGVTBPBI $_{\mathrm{i}}=0.011 \mathrm{SAGI}_{\mathrm{i}}+1920.372$

Research Question 8b: Is there a relationship between Tuition and fees minus all grants, veteran, and tax benefits for in-state students enrolled at private institutions and adjusted gross income? Research Question $8 \mathrm{~b}$ relates to Hypothesis $\left(\mathrm{H}_{8 \mathrm{~b}}\right)$, that there is no significant relationship between tuition and fees minus all grants, veteran, and tax benefits for in- 
state students enrolled at private institutions and adjusted gross income. As described in Chapter 3, Equation $8 \mathrm{~b}$ relates to Research Question $8 \mathrm{~b}$ and Hypothesis $8 \mathrm{~b}$ :

$$
\mathrm{TGVTBPVI}_{\mathrm{i}}=\mathrm{AGI}_{\mathrm{i}}
$$

The significance scores for this equation are displayed in Table 98. The NCES' DAS was used to perform a weighted least squares computation using NPSAS: 04 data. Both of the variables for this equation were significant. The coefficient of determination was .0984. From this statistic, we may conclude that 9.84 percent of the variance in amount of tax benefit received from federal tax credits and deductions per student enrolled in private institutions is explained by the independent variables in this equation. The regression coefficients for this equation are displayed in Table 99.

Table 98: Equation 8b hypothesis testing results

\begin{tabular}{|c|c|c|c|c|c|}
\hline & Wald $F$ & $\begin{array}{l}\text { Num. } \\
\text { DF }\end{array}$ & $\begin{array}{l}\text { Denom. } \\
\text { DF }\end{array}$ & Commonality & $\begin{array}{l}\text { Probability } \\
F\end{array}$ \\
\hline Overall Fit & 245.397 & 1 & 64 & & .001 \\
\hline $\begin{array}{l}\text { Adjusted Gross Income } \\
\text { (AGI) }\end{array}$ & 245.397 & 1 & 64 & .098 & .001 \\
\hline
\end{tabular}

Table 99: Equation 8b estimated full sample regression coefficients

\begin{tabular}{|l|r|l|l|r|}
\hline & B & s.e. & \multicolumn{1}{|c|}{ Probability $t$} \\
\hline Intercept & 5315.2 & 212.878 & 24.968 & .001 \\
\hline $\begin{array}{l}\text { Adjusted Gross Income } \\
\text { (AGI) }\end{array}$ & .043 & .003 & 15.665 & .001 \\
\hline
\end{tabular}

The correlation for this equation is displayed in Table 100.

Table 100: Equation 8b correlation

\begin{tabular}{|l|l|l|}
\hline & $\begin{array}{l}\text { Tuition and fees minus } \\
\text { all grants, veteran, and } \\
\text { tax benefits (TGVTPVI) }\end{array}$ & $\begin{array}{l}\text { Adjusted Gross } \\
\text { Income (AGI) }\end{array}$ \\
\hline $\begin{array}{l}\text { Tuition and fees minus } \\
\text { all grants, veteran, and } \\
\text { tax benefits (TGVTPVI) }\end{array}$ & 1 & 0.314 \\
\hline $\begin{array}{l}\text { Adjusted Gross Income } \\
\text { (AGI) }\end{array}$ & 0.314 & \\
\hline
\end{tabular}


The relationship between the amount of institutional need-based financial grant aid paid per student by public institutions and related market variables is represented by the following econometric equation:

TGVTBPVI $_{\mathrm{i}}=0.043 \mathrm{SAGI}_{\mathrm{i}}+5315.2$

Research Question 8c: Does the amount of tuition and fees minus all grants, veteran, and tax benefits for in-state students at public institutions differ from the amount of tuition and fees minus all grants, veteran, and tax benefits for in-state students at private institutions? Research Question 8c relates to Hypothesis $\left(\mathrm{H}_{8 \mathrm{c}}\right)$, that the amount of tuition and fees minus all grants, veteran, and tax benefits for in-state students at public institutions was less than or equal to the amount of tuition and fees minus all grants, veteran, and tax benefits for in-state students at private institutions.

As described in Chapter 3, Equation 8c relates to Research Question 8c and Hypothesis 8c:

TGVTBPBI $\leq$ TGVTBPVI

The data used for the means comparison are displayed in Table 101. The following formula was used to calculate the $t$ value:

$$
t_{d f}=\frac{\left|\bar{x}_{A}-\bar{x}_{B}\right|}{\sqrt{\hat{V}_{A}+\hat{V}_{B}}}
$$

The means for the two groups that were compared are represented by $\bar{x}_{A}$ and $\bar{x}_{B}$. The respective squared standard errors associated with the means are represented by $\hat{V}_{A}$ and $\hat{V}_{B}$. 
The $t$ value for the comparison of the two means was 32.32. Because the test statistic exceeds the critical value of \pm 1.96 , the difference between the two means is statistically significant.

Table 101: Equation 8c group statistics

\begin{tabular}{|l|r|r|}
\hline & Mean & Standard Error \\
\hline Public Institutions & 1026.623 & 21.501 \\
\hline Private Institutions & 6192.990 & 158.404 \\
\hline
\end{tabular}

\section{Research Question 8d: Is there a relationship between Tuition and fees minus all} grants, veteran, and tax benefits for out-of-state students enrolled at public institutions and adjusted gross income? Research Question $8 \mathrm{~d}$ relates to Hypothesis $\left(\mathrm{H}_{8 \mathrm{~d}}\right)$, that there is no significant relationship between tuition and fees minus all grants, veteran, and tax benefits for out-of-state students enrolled at public institutions and adjusted gross income. As described in Chapter 3, Equation 8d relates to Research Question 8d and Hypothesis 8d:

$$
\text { TGVTBPBO }_{\mathrm{i}}=\mathrm{AGI}_{\mathrm{i}}
$$

The significance scores for this equation are displayed in Table 102. The NCES' DAS was used to perform a weighted least squares computation using NPSAS: 04 data. Both of the variables for this equation were significant. The coefficient of determination was .0963 . From this statistic, we may conclude that 9.63 percent of the variance in amount of tax benefit received from federal tax credits and deductions per student enrolled in private institutions is explained by the independent variables in this equation. The regression coefficients for this equation are displayed in Table 103. 
The relationship between the amount of institutional need-based financial grant aid paid per student by public institutions and related market variables is represented by the following econometric equation:

Table 102: Equation 8d hypothesis testing results

\begin{tabular}{|l|r|r|r|r|r|}
\hline & Wald F & $\begin{array}{l}\text { Num } \\
\text {. DF }\end{array}$ & $\begin{array}{l}\text { Denom. } \\
\text { DF }\end{array}$ & Commonality & $\begin{array}{l}\text { Probability } \\
F\end{array}$ \\
\hline Overall Fit & 72.111 & 1 & 64 & & .001 \\
\hline $\begin{array}{l}\text { Adjusted Gross Income } \\
\text { (SAGI) }\end{array}$ & 72.111 & 1 & 64 & .080 & .001 \\
\hline
\end{tabular}

Table 103: Equation 8d estimated full sample regression coefficients

\begin{tabular}{|l|r|r|r|r|}
\hline & \multicolumn{1}{|l|}{ B } & \multicolumn{1}{l|}{ s.e. } & \multicolumn{1}{l|}{ Probability $t$} \\
\hline Intercept & 5892.600 & 485.163 & 12.146 & .001 \\
\hline $\begin{array}{l}\text { Adjusted Gross Income } \\
\text { (SAGI) }\end{array}$ & 0.030 & 0.004 & 8.492 & .001 \\
\hline
\end{tabular}

The correlation for this equation is displayed in Table 104.

Table 104: Equation 8d correlation

\begin{tabular}{|l|l|r|}
\hline & $\begin{array}{l}\text { Tuition and fees minus all grants, } \\
\text { veteran, and tax benefits } \\
\text { (TGVTPBO) }\end{array}$ & $\begin{array}{l}\text { Adjusted Gross } \\
\text { Income (AGI) }\end{array}$ \\
\hline $\begin{array}{l}\text { Tuition and fees minus all } \\
\text { grants, veteran, and tax } \\
\text { benefits (TGVTPBO) }\end{array}$ & 1 & 0.283 \\
\hline $\begin{array}{l}\text { Adjusted Gross Income } \\
\text { (SAGI) }\end{array}$ & 0.283 & 1 \\
\hline
\end{tabular}

TGVTBPBO $_{\mathrm{i}}=0.03 \mathrm{SAGI}_{\mathrm{i}}+5892.6$

\section{Research Question 8e: Is there a relationship between Tuition and fees minus all} grants, veteran, and tax benefits for out-of-state students enrolled at private institutions and adjusted gross income? Research Question 8e relates to Hypothesis $\left(\mathrm{H}_{8 \mathrm{e}}\right)$, that there is no significant relationship between tuition and fees minus all grants, veteran, and tax benefits for 
out-of-state students enrolled at private institutions and adjusted gross income. As described in Chapter 3, Equation 8e relates to Research Question 8e and Hypothesis 8e:

$$
\text { TGVTBPVO }_{\mathrm{i}}=\mathrm{AGI}_{\mathrm{i}}
$$

The significance scores for this equation are displayed in Table 105. The NCES' DAS was used to perform a weighted least squares computation using NPSAS: 04 data. Both of the variables for this equation were significant. The coefficient of determination was .144. From this statistic, we may conclude that 14.4 percent of the variance in amount of tax benefit received from federal tax credits and deductions per student enrolled in private institutions is explained by the independent variables in this equation. The regression coefficients for this equation are displayed in Table 106.

Table 105: Equation 8e hypothesis testing results

\begin{tabular}{|c|c|c|c|c|c|}
\hline & Wald $F$ & $\begin{array}{l}\text { Num. } \\
\text { DF }\end{array}$ & $\begin{array}{l}\text { Denom. } \\
\text { DF }\end{array}$ & Commonality & $\begin{array}{l}\text { Probability } \\
F\end{array}$ \\
\hline Overall Fit & 171.689 & 1 & 64 & & .001 \\
\hline $\begin{array}{l}\text { Adjusted Gross Income } \\
\text { (AGI) }\end{array}$ & 171.689 & 1 & 64 & 0.144 & .001 \\
\hline
\end{tabular}

Table 106: Equation 8e estimated full sample regression coefficients

\begin{tabular}{|l|r|r|r|r|}
\hline & \multicolumn{1}{|l|}{ B } & \multicolumn{1}{l|}{ s.e. } & \multicolumn{1}{l|}{ t } & Probability $t$ \\
\hline Intercept & 8046.187 & 559.354 & 14.385 & .001 \\
\hline $\begin{array}{l}\text { Adjusted Gross Income } \\
\text { (AGI) }\end{array}$ & .059 & .004 & 13.103 & .001 \\
\hline
\end{tabular}

The correlation for this equation is displayed in Table 107.

Table 107: Equation 8e correlations

\begin{tabular}{|l|l|l|}
\hline & $\begin{array}{l}\text { Tuition and fees minus } \\
\text { all grants, veteran, and } \\
\text { tax benefits (TGVTPBO) }\end{array}$ & $\begin{array}{l}\text { Adjusted Gross Income } \\
\text { (AGI) }\end{array}$ \\
\hline $\begin{array}{l}\text { Tuition and fees minus } \\
\text { all grants, veteran, and } \\
\text { tax benefits (TGVTPVO) }\end{array}$ & $\begin{array}{l}\text { Adjusted Gross Income } \\
\text { (AGI) }\end{array}$ & 0.379 \\
\hline $\begin{array}{l}\text { Adjusted Gross Income } \\
\text { (SAGI) }\end{array}$ & 0.379 & \\
\hline
\end{tabular}


The relationship between the amount of institutional need-based financial grant aid paid per student by public institutions and related market variables is represented by the following econometric equation:

TGVTBPVO $_{\mathrm{i}}=0.059 \mathrm{SAGI}_{\mathrm{i}}+8046.187$

Research Question 8f: Does the amount of tuition and fees minus all grants, veteran, and tax benefits for out-of-state students at public institutions differ from the amount of tuition and fees minus all grants, veteran, and tax benefits for out-of-state students at private institutions? Research Question $8 \mathrm{f}$ relates to Hypothesis $\left(\mathrm{H}_{8 \mathrm{f}}\right)$, that the amount of tuition and fees minus all grants, veteran, and tax benefits for out-of-state students at public institutions was less than or equal to the amount of tuition and fees minus all grants, veteran, and tax benefits for out-of-state students at private institutions.

As described in Chapter 3, Equation $8 \mathrm{f}$ relates to Research Question 8f and Hypothesis 8f:

TGVTBPBO $\leq$ TGVTBPVO

The data used for the means comparison are displayed in Table 108. The following formula was used to calculate the $t$ value:

$$
t_{d f}=\frac{\left|\bar{x}_{A}-\bar{x}_{B}\right|}{\sqrt{\hat{V}_{A}+\hat{V}_{B}}}
$$

The means for the two groups that were compared are represented by $\bar{x}_{A}$ and $\bar{x}_{B}$. The respective squared standard errors associated with the means are represented by $\hat{V}_{A}$ and $\hat{V}_{B}$. 
The $t$ value for the comparison of the two means was 9.31. Because the test statistic exceeds the critical value of \pm 1.96 , the difference between the two means is statistically significant.

Table 108: Equation 8f group statistics

\begin{tabular}{|l|c|r|}
\hline & Mean & Standard Error \\
\hline Public Institutions & 5191.594 & 293.697 \\
\hline Private Institutions & 11015.060 & 552.603 \\
\hline
\end{tabular}

Regression equations were calculated for the markets within which higher education institutions and their students interact. Separate equations were used to examine private institutions and public institutions.

\section{Summary}

The results from the instructional services market indicate that the determinants of tuition are similar for public and private institutions. Predictors of in-state tuition for both types of institutions include selectivity, Carnegie Foundation classifications, the per capita tax revenue for the state in which the school is operated and depreciation expenses. For out of state tuition, the common predictors are the same except for the per capita tax revenue for the state in which the school is operated.

The only common determinant of the equations for the market for value provided to contributors is depreciation expenses. Selectivity of private institutions is the only additional significant determinant for this market.

For the market for value provided to state governments, no significant determinants were identified for private institutions. Significant determinants for public institutions in this market 
are selectivity, the current enrollments as a percentage of the sum of the high-school graduates for the past four years, and depreciation expenses.

In the market for value provided to the federal government, depreciation expenses are determinants for public and private institutions. Additional determinants for private institutions are their status as 1862 land grant institutions and their Carnegie Foundation classifications.

In the market to Attract Students with Certain Characteristics, several common determinants were found for public and private institutions. Students' ages are determinants for all of the equations in this market. For merit-based aid, students' grade point averages are determinants. Adjusted gross income is a common determinant for need-based aid. The statuses of the students in relation to the state within which the schools are located are determinants for need-based aid. For both state and federal government need-based aid, the education levels of students' parents are significant determinants.

Finally, the relationship between the amounts of tuition and fees minus all grants, veteran, and tax benefits for students enrolled at private and public institutions and adjusted gross income is significant. This relationship is significant for both in-state and out-of-state students. In addition, the amounts of tuition and fees minus all grants, veteran, and tax benefits for students enrolled at private institutions is significantly higher than the tuition and fees minus all grants, veteran, and tax benefits for students enrolled at private institutions. These findings will be used to demonstrate that affluent families pay less than market rates for public higher education. 


\section{CHAPTER FIVE}

\section{Summary, Findings, Conclusions, and Recommendations}

This chapter includes a summary of the study and a discussion of the results described in Chapter IV. Recommendations for action and further study are also presented.

The higher education economy in the United States is driven through a complex web of markets. Some markets have been established for centuries whereas others have been developed more recently. As stated in Chapter 1, the purpose of this study was to determine if governmental expenditures for human capital development in higher education markets are allocated efficiently. Specifically, do affluent families pay less than market rates for higher education? To answer this question, it was necessary to understand the purposes for which public higher education institutions were founded. These colleges and universities were established mainly to promote the development of human capital and train teachers for public schools.

From the historical context developed in the first section of Chapter 2, a framework for higher education markets was developed. This framework was developed by using price discrimination theory to analyze higher education economic transactions. Five markets were identified. The first three markets provide revenues directly to colleges and universities and the other two markets provide financial aid to students. Institutions receive resources from the markets for educational services, value provided to contributors and value provided to governmental entities. Schools provide financial aid to students in the market to attract students with certain characteristics. Governmental entities provide financial aid to students through the market to provide governmental funds to students.

Using this market framework, this study examined the relationships of institutional and student characteristics to revenue sources in each market. The economies for public and private 
institutions were compared to analyze the unique effects of state appropriations and public tuition policies.

Econometric equations were developed for each market. Data were analyzed separately for public and private institutions. In addition, tuition as well as institutional and state financial aid data were analyzed for in-state and out-of-state students.

Quantitative research was performed to address the research questions. The primary source of data for this study was the NCES. IPEDS data from 2004, the NPSAS:04 information and the NCES Common Core of Data were used. In addition, data from the U.S. Census Bureau, Philanthropic Research, Inc., the National Conference of State Legislatures, and the National Association of State and University Land Grant Institutions were utilized.

Multivariate regressions were used to analyze all data except for the NPSAS:04 information. Eigen values were calculated to detect collinearity problems with the multivariate regressions. For the NPSAS:04 data, weighted least squares correlations were computed using the balanced repeated replication method. No significant collinearity problems were detected for these correlations. The DAS will not calculate correlations from NPSAS:04 data if significant collinearity problems exist.

For this study, 36 hypotheses were developed. Of the 15 multivariate regression equations, 14 were significant. All of the weighted least squares equations were significant and the 11 of the 12 tests of variances between means were significant. The 36 hypotheses were developed to analyze the five markets identified in the literature review. Table 109 lists the markets and their corresponding hypotheses.

Table 109: Markets and related hypotheses

\begin{tabular}{|l|l|}
\hline Market & Hypothesis \\
\hline Educational Services & $1 \mathrm{a}, 1 \mathrm{~b}, 1 \mathrm{c}, 1 \mathrm{~d}, 1 \mathrm{e}, 1 \mathrm{f}$ \\
\hline Value Provided to Contributors & $2 \mathrm{a}, 2 \mathrm{~b}, 2 \mathrm{c}$ \\
\hline Value Provided to Governments & $3 \mathrm{a}, 3 \mathrm{~b}, 3 \mathrm{c}, 4 \mathrm{a}, 4 \mathrm{~b}, 4 \mathrm{c}$ \\
\hline
\end{tabular}




\begin{tabular}{|l|l|}
\hline Students with Certain Characteristics & $5 a, 5 b, 5 c, 5 d, 5 e, 5 f$ \\
\hline Governmental funds for students & $6 a, 6 b, 6 c, 6 d, 6 e, 6 f, 7 a, 7 b, 7 c$ \\
\hline
\end{tabular}

\section{Major Findings}

For a majority of the regression equations, the coefficients of determination $\left(\mathrm{r}^{2}\right)$ were stronger for private institutions. These results are displayed in Table 110. Public institutions exhibited stronger correlations for donations, state appropriations, federal operating revenues and state merit-based financial aid.

The equations for markets that generate direct institutional revenues produced stronger correlations than markets that generated financial aid for students. The exception was the equation for per student state government appropriations made to private institutions. It was anticipated that state appropriations for public institutions would be more significantly correlated with the chosen independent variables than private institutions. A uniform approach to state funding of private colleges and universities does not exist.

The first ten equations relate to direct institutional revenues and the remainder of the equations relate to student financial aid as well as tuition and fees. The stronger correlations for direct institutional revenues may result from the smaller number of recipients in these markets. There are many more recipients of financial aid and their individual marketing effectiveness is limited. Furthermore, students may choose to attend institutions for reasons that are not related to the variables identified in this study.

Table 110: Coefficients of Determination

\begin{tabular}{|l|l|l|l|r|}
\hline \multirow{2}{*}{ Dependent Variable } & \multicolumn{2}{c|}{ Public Institutions } & \multicolumn{2}{c|}{ Private Institutions } \\
\cline { 2 - 5 } & Hypothesis & $\boldsymbol{r}^{2}$ & \multicolumn{1}{c|}{ Hypothesis } & $\boldsymbol{r}^{2}$ \\
\hline In-state tuition and fees & $1 \mathrm{a}$ & .156 & $1 \mathrm{~b}$ & .360 \\
\hline Out-of-state tuition and fees & $1 \mathrm{~d}$ & .204 & $1 \mathrm{e}$ & .360 \\
\hline $\begin{array}{l}\text { Total amount of revenues collected from } \\
\text { private donation per student }\end{array}$ & $2 \mathrm{a}$ & .864 & $2 \mathrm{~b}$ & .251 \\
\hline
\end{tabular}




\begin{tabular}{|l|l|r|l|l|}
\hline $\begin{array}{l}\text { Per student state government } \\
\text { appropriations }\end{array}$ & $3 \mathrm{a}$ & .432 & $3 \mathrm{~b}$ & .057 \\
\hline $\begin{array}{l}\text { Federal operating revenues provided per } \\
\text { student }\end{array}$ & $4 \mathrm{a}$ & .922 & $4 \mathrm{~b}$ & .508 \\
\hline Institutional merit-based financial aid & $5 \mathrm{a}$ & .038 & $5 \mathrm{~b}$ & .108 \\
\hline Institutional need-based financial aid & $5 \mathrm{~d}$ & .022 & $5 \mathrm{e}$ & .093 \\
\hline State merit-based financial aid & $6 \mathrm{a}$ & .028 & $6 \mathrm{~b}$ & .259 \\
\hline State need-based financial aid & $6 \mathrm{~d}$ & .106 & $6 \mathrm{e}$ & .171 \\
\hline Federal grant aid per student & $7 \mathrm{a}$ & .226 & $7 \mathrm{~b}$ & .184 \\
\hline $\begin{array}{l}\text { Tuition and fees minus all grants veteran } \\
\text { and tax benefits for in-state students }\end{array}$ & $8 \mathrm{a}$ & .074 & $8 \mathrm{~b}$ & .098 \\
\hline $\begin{array}{l}\text { Tuition and fees minus all grants veteran } \\
\text { and tax benefits for in-state students }\end{array}$ & $8 \mathrm{~d}$ & .096 & $8 \mathrm{e}$ & .144 \\
\hline
\end{tabular}

The independent variable Depreciation expense per student was significant for the first ten equations. This result indicates that a strong relationship exists between institutional wealth as demonstrated by depreciation expense and its ability to generate revenues.

Table 111 provides a summary of the equations that analyze the difference between means for the dependent variables used in the regression equations. Only the difference between state-merit-based financial grant aid received by students at public and private institutions was not significant. For all other equations, the differences between the variable means for public and private institutions were significant.

Table 111: Difference Between the Means Results

\begin{tabular}{|c|c|c|c|c|c|c|c|}
\hline Equation & $\begin{array}{l}\text { Variable } \\
\text { Name }\end{array}$ & $\begin{array}{l}\text { Control of } \\
\text { institution }\end{array}$ & $\mathrm{N}$ & Mean & $\begin{array}{c}\text { Std. } \\
\text { Deviation }\end{array}$ & $\begin{array}{c}\text { Std. } \\
\text { Error } \\
\text { Mean }\end{array}$ & $t$-value \\
\hline \multirow[t]{2}{*}{$1 \mathrm{c}$} & \multirow{2}{*}{$\begin{array}{l}\text { In-state } \\
\text { tuition and } \\
\text { fees per } \\
\text { student }\end{array}$} & Public & 506 & 4429.460 & 1553.125 & 69.045 & \multirow[t]{2}{*}{-61.783} \\
\hline & & Private & 861 & 17420.360 & 5827.704 & 198.608 & \\
\hline \multirow[t]{2}{*}{ if } & \multirow{2}{*}{$\begin{array}{l}\text { Out-of-state } \\
\text { tuition and } \\
\text { fees per } \\
\text { student }\end{array}$} & Public & 506 & 11192.420 & 3400.597 & 151.175 & \multirow[t]{2}{*}{-24.958} \\
\hline & & Private & 861 & 17421.220 & 5826.709 & 198.574 & \\
\hline
\end{tabular}




\begin{tabular}{|c|c|c|c|c|c|c|c|}
\hline \multirow[t]{2}{*}{20} & \multirow{2}{*}{$\begin{array}{l}\text { Total } \\
\text { amount of } \\
\text { revenues } \\
\text { collected } \\
\text { from } \\
\text { donations } \\
\text { per student }\end{array}$} & Public & 504 & 431.471 & 1965.039 & 87.530 & \multirow[t]{2}{*}{-16.344} \\
\hline & & Private & 797 & 4351.001 & 6303.137 & 223.269 & \\
\hline \multirow[t]{3}{*}{$3 \mathrm{c}$} & \multirow{3}{*}{$\begin{array}{l}\text { Total } \\
\text { amount of } \\
\text { revenues } \\
\text { collected } \\
\text { from state } \\
\text { appropriatio } \\
\text { ns per } \\
\text { student }\end{array}$} & Public & 512 & 6296.534 & 4374.669 & 193.335 & \multirow[t]{3}{*}{-32.258} \\
\hline & & & & & & & \\
\hline & & Private & 873 & 50.3875 & 316.432 & 10.709 & \\
\hline \multirow[t]{2}{*}{$4 \mathrm{c}$} & \multirow{2}{*}{$\begin{array}{l}\text { Federal } \\
\text { operating } \\
\text { revenues } \\
\text { provided per } \\
\text { student }\end{array}$} & Public & 512 & 3099.854 & 8150.670 & 360.212 & \multirow[t]{2}{*}{2.420} \\
\hline & & Private & 873 & 2049.927 & 7111.125 & 240.675 & \\
\hline \multirow[t]{2}{*}{$5 c$} & \multirow{2}{*}{$\begin{array}{l}\text { Institutional } \\
\text { merit-based } \\
\text { financial } \\
\text { grant aid per } \\
\text { student }\end{array}$} & Public & 18772 & 144.022 & & 9.217 & \multirow[t]{2}{*}{12.320} \\
\hline & & Private & 10893 & 1531.363 & & 112.228 & \\
\hline \multirow[t]{2}{*}{$5 \mathrm{f}$} & \multirow{2}{*}{$\begin{array}{l}\text { Institutional } \\
\text { need-based } \\
\text { financial aid } \\
\text { paid by }\end{array}$} & Public & 18772 & 122.110 & & 4.164 & \multirow[t]{2}{*}{19.190} \\
\hline & & Private & 10893 & 1685.560 & & 81.356 & \\
\hline \multirow[t]{2}{*}{$6 c$} & \multirow{2}{*}{$\begin{array}{l}\text { State-merit- } \\
\text { based } \\
\text { financial } \\
\text { grant aid } \\
\text { received by } \\
\text { students }\end{array}$} & Public & 18772 & 64.595 & & 2.343 & \multirow[t]{2}{*}{.460 } \\
\hline & & Private & 10893 & 58.817 & & 12.434 & \\
\hline \multirow[t]{2}{*}{$6 \mathrm{f}$} & \multirow{2}{*}{$\begin{array}{l}\text { State-need } \\
\text { based } \\
\text { financial } \\
\text { grant aid } \\
\text { received by } \\
\text { students }\end{array}$} & Public & 18772 & 172.3023 & & 5.9485 & \multirow[t]{2}{*}{11.25} \\
\hline & & Private & 10893 & 548.621 & & 32.910 & \\
\hline $7 \mathrm{c}$ & $\begin{array}{l}\text { Federal } \\
\text { grants, } \\
\text { veterans and }\end{array}$ & Public & 18772 & 957.568 & & 8.157 & 22.430 \\
\hline
\end{tabular}




\begin{tabular}{|l|l|l|l|l|l|l|l|}
\hline & $\begin{array}{l}\text { tax benefits } \\
\text { received at } \\
\text { public } \\
\text { institutions }\end{array}$ & Private & 10893 & 1452.119 & & 20.483 & \\
\hline $8 \mathrm{c}$ & $\begin{array}{l}\text { Tuition and } \\
\text { fees minus } \\
\text { all grants, } \\
\text { veteran, and } \\
\text { tax benefits } \\
\text { for in-state } \\
\text { students }\end{array}$ & Public & 18772 & 1026.623 & & 21.501 & 32.320 \\
\cline { 2 - 7 } $8 \mathrm{f}$ & $\begin{array}{l}\text { Tuition and } \\
\text { fees minus } \\
\text { all grants, } \\
\text { veteran, and } \\
\text { tax benefits } \\
\text { for out-of- } \\
\text { state } \\
\text { students }\end{array}$ & Private & 10893 & 6192.99 & & 158.404 & \\
\cline { 2 - 7 } & & 18772 & 5191.594 & & 293.697 & 9.310 \\
\hline
\end{tabular}

\section{Instructional Services Market}

To analyze the characteristics of the instructional services market, Hypotheses $\mathrm{H}_{1 \mathrm{a}}$ through $\mathrm{H}_{1 \mathrm{f}}$ were developed. Four of these equations were regression calculations. The independent variables Selectivity, Carnegie Foundation classification, and Depreciation expenses per students were significant for all four equations. The independent variable Per-capita tax revenue for the state in which the institution is operated is insignificant only for out-of-state tuition and fees per student charged by public institutions. The variable Political power in the legislature was only significant for In-state tuition and fees per student charged by public institutions. 


\section{$H_{1 a}:$ Relationship between the amount of tuition and fees per student charged to in-state students by public institutions, institutional characteristics, and the economic and political characteristics of the states}

The results of this study indicate that public tuition and fees per student are negatively correlated with the selectivity of institutions. Consequently, institutions that enroll a higher percentage of applicants have lower tuition rates, ceteris paribus. Public Tuition decreased $\$ 976.12$ for every percentage increase in the percentage of applicants enrolled. Tuition and fees are also negatively correlated with schools' Carnegie Foundation classification. The numeric values for this variable were assigned by classification rank. The highest level rank was assigned the value of one and the lowest level rank was assigned a value of seven. The results of the regression equation indicate that institutions with higher Carnegie Classification ranks charged more for tuition and fees. Tuition and fees decreased $\$ 158.86$ for each change in rank. The per capita tax revenue for the state within which the institutions were operated was positively correlated with tuition and fee rates. The study indicates that institutions in states with higher levels of income generally charge more than states with lower levels of income. Tuition and fees increased $\$ 21.50$ for every $\$ 100$ increase in per capita tax revenue. Tuition and fees were negatively correlated with the variable for political power in the legislature. The higher numeric value for this variable is assigned to the Republican Party. As a result, tuition and fee charges are \$14 less on average than states with Democratic Party control of legislative bodies. Depreciation expenses per student are also positively correlated with public tuition and fees per student. Tuition and fees increase $\$ 17.48$ for every $\$ 10$ increase in depreciation expenses per student. It appears that institutions that invest more money in their physical plants charge higher rates for tuition and fees. 
$H_{1 b}$ : Relationship between the amount of tuition and fees per student charged to in-state students by private institutions, institutional characteristics, and the economic and political characteristics of the state

The results for private institutions were very similar to those of public schools. Tuition and fees per student were negatively correlated with selectivity and Carnegie Foundation classification. Tuition and fees decreased $\$ 2,643$ for every percentage increase in the number of applicants enrolled. For each increase in Carnegie Foundation rank, the tuition and fees increased \$667. The per capita tax revenue for the state in which the institutions were operated was positively correlated with tuition and fee levels. Tuition and fees increased $\$ 140$ for every $\$ 100$ increase in per-capita income tax revenue. In addition, depreciation expenses per student were also positively correlated with tuition and fees. Tuition and fees increased $\$ 139$ for every $\$ 100$ increase in depreciation expenses per student. Unlike public institutions, political power in the legislature was not significant. It appears that the control of legislative bodies by political parties has no significant bearing on tuition and fee rates for private institutions.

$H_{1 c}:$ Means comparison between tuition and fees per student charged to in-state students by private institutions and the tuition and fees charged to in-state students by public institutions

The mean tuition and fees charged to in-state students by public institutions was $\$ 4,429$ compared to $\$ 17,420$ for tuition and fees charged to in-state students by private institutions. The low tuition rates for public institutions coincide with historical tuition policies. Most public institutions were founded with the intent to charge little or no tuition and fees. 
$H_{1 d}:$ Relationship between the amount of tuition and fees per student charged to out-of-state students by public institutions, institutional characteristics, and the economic and political characteristics of the states

For out-of-state students who attend public institutions, institutions' selectivity and Carnegie Foundation classifications were negatively correlated with tuition and fee prices. For every percentage decrease in the number of applicants enrolled, tuition and fees increased $\$ 2,378$. Tuition and fees decreased $\$ 896$ for each numerical increase in Carnegie Foundation classification. Again, the higher level institutions were assigned a value of one, and the lowest ranking institutions were assigned a value of seven. Tuition and fees increased $\$ 227$ for every $\$ 100$ increase in depreciation expenses per student.

$H_{1 e}$ : Relationship between the amount of tuition and fees per student charged to out-of-state students by private institutions, institutional characteristics, and the economic and political characteristics of the states

The results for out-of-state students who attended private institutions were identical to the results for in-state students who attended private institutions. Private colleges and universities charge in-state and out-of-state students the same rates. They were the same as the results for out-of-state tuition and fees paid to public institutions. The selectivity and Carnegie Foundation classification variables were negatively correlated with the dependent variable, and depreciation expenses was positively correlated with tuition and fee rates. An additional variable, the percapita tax revenue for the state within which the institution is located, was also positively correlated with the dependent variable. 
$H_{1 f}:$ Means comparison between tuition and fees per student charged to out-of-state students by private institutions and tuition and fees charged to out-of-state students by public institutions

The mean tuition and fees charged to out-of-state students at public institutions was $\$ 11,192$ compared to $\$ 17,421$ for tuition and fees charged to out-of-state students at private institutions. The literature review did not reveal a consistent method for the determination of public out-of state tuition and fee rates. Because the rates are not similar to the rates charged by private institutions, it does not appear that the rates are established primarily from market studies.

The study by Tiffany and Ankrom (1998) analyzed the relationship between two independent variables, net revenues and enrollment and the independent variables tuition price, endowments, the number of students who paid full price, and, institutional grants per student. Because these authors mixed data from markets identified separately in this study, the comparisons of outcomes is not relevant.

Lowry (2001) found that net tuition and fees for public institutions are related to states' higher education governance structures, the local cost of living, per capita income, and the percentage of 18 year-olds beginning college in the fall. Lowry's cost of living variable and this studies per-capita tax revenues variable may be a measure of the same phenomena. Both variables reflect the level of states' incomes. 


\section{Market for Value Provided to Contributors}

Three equations were created to analyze the market for value provided to contributors. The first two equations are regression calculations. Although there were few significant determinants found, the Pearson product-moment correlation values (r) were relatively high. $H_{2 a:}$ Relationship between the amounts of revenues collected from private donations per student by public institutions, institutional characteristics, and academic programs.

The data from the study support a very strong relationship between depreciation expense per student and the private donations per student collected by public institutions. Donations increased $\$ 847$ for every $\$ 1,000$ increase in depreciation expenses per student. No significant relationships were found between the private donations per student received by public institutions and institutional selectivity, Carnegie Foundation classification, and programs.

\section{$H_{2 b:}$ Relationship between the amounts of revenues collected from private donations per student by private institutions, institutional characteristics, and academic programs}

A significant relationship was also identified between the depreciation expenses per student and private donations per student received by private institutions. For every $\$ 1,000$ increase in depreciation expenses per student, donations increased $\$ 1,741$. The selectivity of institutions was also significant. The results of this study indicate that public tuition and fees per student are negatively correlated with the selectivity of institutions. Consequently, institutions that enroll a higher percentage of applicants have lower levels of donations, ceteris paribus. For every percentage decline in the number of applicants enrolled, the amount of donations increased $\$ 3,738$. 


\section{$\mathrm{H}_{2 c}$ : Private donations per student by private institutions is less than or equal to the private donations received by public institutions}

The average donations per student received by public institutions were $\$ 431$ compared to $\$ 4,351$ for private colleges and universities. This disparity could exist for multiple reasons. Donors may believe that public colleges and universities need minimal private support because they receive governmental appropriations. These institutions also may not dedicate as many resources as private institutions commit to fund raising efforts.

The relationship between depreciation expenses and donations indicates that donors tend to give to institutions that have accumulated wealth. This phenomenon was noted by Ehrenberg and Smith (2003) in their study of higher education institutions. These authors found that donations correlated significantly with the level of endowments. They also found a relationship between donations and the percentage of graduates from business and engineering programs. A relationship between academic programs and donations may not have been established in this study because the sample size is larger and more diverse. Ehrenberg and Smith (2003) only selected 30 national liberal arts and research institutions for their study. A relationship between institutions' endowment levels and the level of donations was also documented by Cunningham and Cochi-Ficano (2002). These authors also found a relationship between student quality and donations. They used students' SAT scores and high school class rank to measure student quality. This study only found a relationship between donations to private institutions and student quality as measured by the institutions' acceptance rates. A similar relationship was not found for public institutions. Because Cunningham and Cochi-Ficano did not distinguish between the donations received at public and private institutions, it cannot be determined if they would have realized similar results for the public institutions in their study. 


\section{Market for Value Provided to Governments}

Six equations were developed to analyze the market for value provided to governments. Four equations were regression calculations. As expected, a large disparity exists between the state appropriations provided public and private institutions. Depreciation was a significant determinant of federal revenues for both public and private institutions.

$H_{3 a}:$ Relationship between the amount of state appropriations per student received by public institutions, institutional characteristics, the economic and political characteristics of the states in which the institutions operate, academic programs, and the available pools of students within the states

The results of the regression equation indicate that state appropriations per student received by public institutions are negatively correlated with the value for selectivity and the depreciation expenses per student. State appropriations decreased $\$ 2,684$ for every percentage increase in the percentage of applicants enrolled. Institutions that are less selective received fewer appropriations per student. A positive correlation with depreciation was also found. For every $\$ 100$ increase in depreciation expenses per student, appropriations increased \$211. $H_{3 b}$ : Relationship between the amounts of state appropriations per student received by private institutions, institutional characteristics, the economic and political characteristics of the states in which the institutions operate, academic programs, and the available pools of students within the states

No significant correlations were found for this equation. The mean amount of state appropriations per student is only $\$ 50$ per student. Policies regarding public appropriations for private institutions may vary greatly among the states. 
$H_{3 c}$ : The amount of state appropriations received by public institutions is less than or equal to the amount of state appropriations received by private institutions

The mean state appropriations per student received by public institutions are $\$ 6,297$. As expected, this is significantly higher than the mean $\$ 50$ in state appropriations per student received by private institutions.

Unlike the research performed by Koshal and Koshal (2000), this study did not show a relationship between state appropriations per student, current enrollment as a percentage of the sum of the high-school graduates for the past four years, the per capita income for the state in which the institution is operated, the percentage of students enrolled in two-year colleges, and political power in the legislatures.

$\mathrm{H}_{4 a}$ : Relationship between the amounts of federal revenues received by public institutions, their statuses as land grant institutions, institutional characteristics, and academic programs

The data from this study indicate a significant relationship between the amount of federal revenues received by public institutions and public depreciation expenses per student. For every $\$ 100$ increase in depreciation expenses per student, the federal operating revenues per student by public institutions increased $\$ 365$. No significant relationship was found between the dependent variable and institutions' land grant statuses.

$H_{4 b}$ : Relationship between the amounts of federal revenues received by private institutions, their statuses as land grant institutions, institutional characteristics, and academic programs

The results of this equation indicate that a relationship exists between the amount of federal revenues per student received by public institutions and private depreciation expenses per student. For every $\$ 100$ increased in depreciation expenses per student, federal operating revenues received per student increased $\$ 298$. Significant relationships are also indicated 
between the dependent variable and institutions' statuses as 1862 land grant institutions and their Carnegie Foundation classifications. Colleges and universities that were classified as 1862 land grant institutions received \$2,548 more than other schools. For each decline in Carnegie Foundation classification rank, the amount received decreased $\$ 596$.

$\mathrm{H}_{4 c}$ : The amount of federal revenues received by public institutions is less than the amount of federal revenues received by private institutions

The mean federal revenues received by public institutions were $\$ 3,099$. This exceeded the $\$ 2,049$ in mean federal revenues received by private institutions. No studies were identified in the literature review that developed econometric equations for higher education federal revenues.

\section{Market to Attract Students with Certain Characteristics}

Six equations were developed to analyze the market to attract students with certain characteristics. Four of these equations were regression calculations. Student age and grade point average were common determinants for all four equations. More determinants were found for public institutions.

\section{$H_{5 a}:$ Relationship between institutional merit-based financial grant aid per student paid by public institutions, student characteristics, and academic programs}

Significant relationships were noted between institutional merit aid per student paid by public institutions and student age, the two race categories White and Black or African American, grade point average, veteran status and students' status as residents of the state in which the institutions are located. For each year increase in the age of students, the amount of institutional merit-based financial aid decreased $\$ 19$. White students receive $\$ 93$ more than 
students who reported more than one race. Black or African-American students received \$329

more than students who reported more than one race. As students grade point averages increased, the amount of the dependent variable increased. For each point increase in grade point average, institutional merit aid increased $\$ 2$. Students who were not veterans received an additional \$89 compared to other students. Finally, students who lived in the same state as their college or university received $\$ 757$ more than students who were not U.S residents.

\section{$H_{5 b}$ : Relationship between institutional merit-based financial grant aid paid per student by private institutions, student characteristics, and academic programs}

The results of this equation indicate a relationship between the dependent variable and student age, adjusted gross income, parent's education levels, grade point average and students statuses as life sciences majors. For each year decrease in student ages, the amount of institutional merit-based aid increased $\$ 101$. For each $\$ 500$ increase in adjusted gross income, merit-based financial aid increases one dollar. Compared to students whose parents held doctoral degrees, students whose parent's attained the indicated education levels received the additional merit - based financial aid listed in Table 112.

Table 112: Equation $5 b$ parent's education levels and changes in dependent variables

\begin{tabular}{|l|l|}
\hline Parent's Education Level & Change in Value of Dependent Variable \\
\hline First-professional degree & $\$ 374.56$ \\
\hline High school diploma or equivalent & $\$ 446.14$ \\
\hline Master's degree or equivalent & $\$ 557.00$ \\
\hline 2 or more years of college but no degree & $\$ 589.91$ \\
\hline Less than two years of college & $\$ 590.93$ \\
\hline Bachelor's degree & $\$ 629.54$ \\
\hline Did not complete high school & $\$ 706.89$ \\
\hline Associate's degree & $\$ 792.84$ \\
\hline Vocational or technical training & $\$ 1066.29$ \\
\hline
\end{tabular}

Merit-based institutional aid increased $\$ 8.40$ for point increase in students' grade point averages. Institutional merit-based aid increased $\$ 1,120.85$ for students who are in life sciences programs. 
$H_{5 c}$ : The amount of institutional merit-based financial grant aid paid per student by public institutions is less than or equal to the amount of institutional merit-based financial grant aid paid per student by private institutions

The mean institutional merit-based financial aid per student for public institutions was $\$ 144$ compared to $\$ 1,531$ for private institutions. This difference appears to be consistent with the difference between tuition charged to students at private institutions and the tuition charged to students at public institutions. It appears that public institutions tend to charge low tuition to all students. Private institutions appear to utilize more institutional aid than public institutions.

\section{$H_{5 d:}$ Relationship between institutional need-based financial grant aid paid per student by public institutions, student characteristics, and academic programs}

The results of this equation indicate relationships between the dependent variable and student age, adjusted gross income, and grade point average. As students ages increased, the level of need-based financial grant aid per student decreased. For every yearly increase in age, the dependent variable decreased $\$ 11$. For every $\$ 1,000$ increase in adjusted gross income, the level of need-based aid decreased one dollar. For each point increase in students' grade point average, the dependent variable increased $\$ 1$. Significant correlations were also found between the dependent variable and students' statuses as Asians and veterans. Asian students received on average $\$ 177$ more than students who reported more than one race. Students who were not veterans received \$71 more need-based financial grant aid than other students. The independent variable for students who did not know their parents' education levels was also significant. On average, these students received $\$ 170$ more than students whose parents had doctorate or 
equivalent degrees. Finally, the variables for students who enrolled in life sciences and vocational/ technical programs were significantly correlated with the dependent variable.

Students enrolled in life sciences received $\$ 128$ more than students enrolled in other/technical programs. Students enrolled in vocational/technical programs received \$97 less than students enrolled in the same comparison group.

\section{$H_{5 e}:$ Relationship between institutional need-based financial grant aid paid per student by private institutions, student characteristics, and academic programs}

For private institutions, this equation also showed significant correlations between the dependent variable students' ages, adjusted gross income and grade point average. Institutional need-based financial grant aid decreased $\$ 98$ for each year increase in students' ages. For every $\$ 1,000$ decrease in adjusted gross income, the dependent variable increased $\$ 7$. Students received \$3 for each point increase in grade point average. Additional relationships were found between the dependent variables for location. Students who were residents of the states in which the institutions were located received on average $\$ 961$ more than students who were foreign or international students. Students who did not reside in the state in which the institution was located received $\$ 1964$ more than foreign or international students. Five program categories were significantly correlated with the dependent variable. Compared to students enrolled in other professional/technical programs, these students received the additional need-based financial aid displayed in Table 113.

Table 113: Equation 5e programs and changes in dependent variables

\begin{tabular}{|l|l|}
\hline Program & Change in Dependent Variable \\
\hline Humanities & $\$ 639.78$ \\
\hline Life sciences & $\$ 677.09$ \\
\hline Undeclared or not in a degree program & $\$ 749.78$ \\
\hline Social/ behavioral sciences & $\$ 1,174.17$ \\
\hline Computer/ information science & $\$ 1,106.58$ \\
\hline Math & $\$ 2,214.24$ \\
\hline
\end{tabular}


$\mathrm{H}_{5 f}:$ The amount of institutional need-based financial grant aid paid per student by public institutions is less than or equal to the amount of institutional need-based financial grant aid paid per student by private institutions

The mean amount of institutional need-based financial grant aid per student by public institutions was $\$ 122$ compared to $\$ 1,686$ for private institutions.

The relationship between institutional financial aid and students' ability and need were found in the literature review. The link between merit-based institutional aid and student grade point average parallels the link noted by Lawson and Zerkle (2006). These authors found a relationship between students' abilities during high school and the amount of financial aid they received. They also reported a relationship between their dependent variable and students nonwhite racial status. Unlike Lawson and Zerkle's research, the results of this study indicate a relationship between students' statuses as White and Black or African-American for public institutions. This study's results may differ from Lawson and Zerkle's research because their data was drawn from a single institution. Kim (2004) also found a relationship between institutional financial aid, financial need and academic merit. She reported that public institutions award less financial aid than private institutions. A higher proportion of merit aid from public institutions was also noted by Kim.

\section{Market to Provide Governmental Funds to Students}

Nine equations were created to analyze the market to provide governmental funds to students. 


\section{$H_{6 a}:$ Relationship between the amounts of state merit-based financial grant aid received per}

student at public institutions, the amount of tuition and fees per student charged to in-state

students, student characteristics, and academic programs

The results of this equation show relationships between the amount of state merit-based financial grant aid received per student at public institutions and tuition, students' ages, adjusted gross income, and grade point average. For every $\$ 1,000$ dollar decrease in tuition, state meritbased aid increased $\$ 5$. The dependent variable decreased $\$ 9$ for each yearly increase in students' ages. Although the relationship with adjusted gross income was significant, the level of state merit-based aid did not change with this variable. For each point increase in students' grade point average, the dependent variable increased \$.82. Students who were residents of the states in which their institutions were located received \$124 more on average than students who students who were foreign or international students. Relationships were also found between the independent variable and nine parents' education levels. Compared to students enrolled in other professional/technical programs, these students received additional need-based financial aid displayed in Table 114.

Table 114: Equation 6a parents education levels and changes in dependent variables

\begin{tabular}{|l|l|}
\hline Parent's Education Level & Change in Dependent Variable \\
\hline Less than two years of college & $\$ 89.94$ \\
\hline Associates' degree & $\$ 77.51$ \\
\hline High school diploma or equivalent & $\$ 76.77$ \\
\hline Vocational or technical training & $\$ 75.45$ \\
\hline Did not know parent's education level & $\$ 72.46$ \\
\hline Bachelor's degree & $\$ 69.25$ \\
\hline Did not complete high school & $\$ 58.04$ \\
\hline 2 or more years of college but no degree & $\$ 42.55$ \\
\hline Master's degree or equivalent & $\$ 41.72$ \\
\hline First professional degree & $\$ 15.51$ \\
\hline
\end{tabular}


Relationships were also indicated between the independent variable and 4 program variables. Compared to students enrolled in other professional/technical programs, these students received the additional or lesser amount of need-based financial aid displayed in Table 115.

Table 115: Equation 6a programs and changes in dependent variables

\begin{tabular}{|l|l|}
\hline Program & Change in Dependent Variable \\
\hline Humanities & $-\$ 29.54$ \\
\hline Physical sciences & $\$ 81.35$ \\
\hline Engineering & $\$ 61.61$ \\
\hline Health & $\$ 79.40$ \\
\hline
\end{tabular}

$H_{6 b}$ : Relationship between the amount of merit-based state financial grant aid received per student at public institutions, the amount of tuition and the fees per student charged to in-state students, student characteristics, and academic programs.

The results of this equation suggest that relationships exists between the dependent variable and students' ages, grade point averages and the variable for students who are residents of the states in which the institutions are located. For each year increase in students' ages, the dependent variable decreased $\$ 6$. Students received $\$ .35$ for each point increase in grade point average. In-state students received $\$ 122$ more on average than students who students who were foreign or international students.

$H_{6 c}$ : The amount of state merit-based financial grant aid per student received at public institutions was less than or equal to the amount of state merit-based grant aid per student received at private institutions

The mean amount of state merit-based financial grant aid per student received at public institutions was $\$ 65$ compared to $\$ 59$ for private institutions. Because the difference between these amounts is small, it appears that states generally do not use the type of institution attended to determine the amount of financial aid awarded to students. 


\section{$H_{6 d:}$ Relationship between the amounts of state need-based financial grant aid received per} student at public institutions, the amount of tuition and fees per student charged to in-state students, student characteristics, and academic programs

The results of this equation indicate that relationships exist between the independent variable and tuition, student ages, adjusted gross income, and grade point average. For every $\$ 1,000$ increase in tuition, financial state-need based aid increased $\$ 48$. For each yearly increase in students' ages, the level of aid decreased \$14. For each point increase in students' grade point averages, the dependent variable increased $\$ .46$. For every $\$ 1,000$ decrease in adjusted gross income, financial aid decreased $\$ 4$. In addition, the race categories Black or African-American, Hispanic or Latino, and Asian were significantly correlated with the dependent variable. Compared to students who indicated the category more than one race, Black or AfricanAmerican, Hispanic or Latino, an Asian students received on average an additional \$129, \$272, and \$371, respectively. Relationships were demonstrated between the dependent variable and both variables for students' residences. Students who resided in the states in which the institutions were located received $\$ 781$ more on average than foreign or international students. United States residents who did not reside in the states in which the institutions were located received \$212 more on average than foreign or international students. The variables for gender and veteran statuses were also significantly correlated with the dependent variable. Male students received $\$ 49$ less than female students, and students who were not veterans received $\$ 105$ less than other students. Finally, the dependent variable is correlated with five parental education levels. Compared to students enrolled in other professional/technical programs, these students received the additional need-based financial aid displayed in Table 116. 
Table 116: Equation 6d parent's education levels and changes in dependent variables

\begin{tabular}{|l|l|}
\hline Parent's Education Level & Change in Dependent Variable \\
\hline Less than two years of college & $\$ 118.69$ \\
\hline Associates' degree & $\$ 122.41$ \\
\hline High school diploma or equivalent & $\$ 135.13$ \\
\hline Did not know parent's education level & $\$ 289.78$ \\
\hline Did not complete high school & $\$ 315.49$ \\
\hline
\end{tabular}

$H_{6 e}:$ Relationship between the amount of need-based state financial grant aid received per student at public institutions, the amount of tuition and the fees per student charged to in-state students, student characteristics and academic programs

The results of this equation show that relationships exist between the dependent variable and tuition, students' ages, adjusted gross income, and student gender. For every $\$ 1,000$ increase in tuition, students received an additional \$31. As students' ages decreased, the level of financial aid increased. For each yearly increase in age, the dependent variable decreased $\$ 23$. Male students received $\$ 110$ less need-based financial aid than female students on average. For every $\$ 1,000$ decrease in adjusted gross income, the dependent variable increased $\$ 6$. Students who lived in the United States received more need-based aid than foreign or international students. Student who lived in the state in which the institutions were located received $\$ 1,042$ more on average than foreign or international students. Those students who did not live in the state in which the institutions were located received $\$ 104$ more on average than foreign or international students. Relationships were also found between the independent variable and eight parents' education levels. Compared to students enrolled in other professional/technical programs, these students received the additional need-based financial aid displayed in Table 117.

Table 117 Equation 6e parent's education level and changes in dependent variables

\begin{tabular}{|l|l|}
\hline Parent's Education Level & Change in Dependent Variable \\
\hline Did not know parent's education level & $\$ 889.57$ \\
\hline Did not complete high school & $\$ 658.45$ \\
\hline
\end{tabular}




\begin{tabular}{|l|l|}
\hline High school diploma or equivalent & $\$ 414.23$ \\
\hline Vocational or technical training & $\$ 372.87$ \\
\hline Less than two years of college & $\$ 408.94$ \\
\hline Associates' degree & $\$ 294.12$ \\
\hline 2 or more years of college but no degree & $\$ 343.52$ \\
\hline Bachelor's degree & $\$ 155.71$ \\
\hline
\end{tabular}

$H_{6 f}:$ The amount of state need-based financial grant aid per student received at public institutions was less than or equal to the amount of state need-based financial grant aid per student received at private institutions

The mean amount of state need-based financial grant aid per student received at public institutions was $\$ 172$ compared to $\$ 549$ for need-based financial grant aid per student received at private institutions. It appears that the amount of state need-based aid provided to students at public and private schools is related to the relationship between the tuition and fee amounts charged to students.

$H_{7 a}:$ Relationship between the amount of federal grants, veteran, and tax benefits received per student by public institutions, the amount of tuition and fees per student charged to in-state students, student characteristics, and the economic and political characteristics of the states

The results of this equation indicate that relationships exist between the dependent variable and tuition and fees, student ages, adjusted gross income, and students' statuses as veterans. For every $\$ 100$ increase in tuition and fees, federal need-based aid increased $\$ 11$. As students' ages increased, the level of federal financial aid decreased. For every $\$ 1,000$ decrease in adjusted gross income, federal financial aid increased $\$ 13$. Students who were not veterans received $\$ 2,148$ less federal financial aid than other students. The race category Black or African-American was also significantly correlated with the dependent variable. Students who identified themselves as Black or African American received an additional \$309 in federal 
financial aid. For each point increase in grade point average, the dependent variable decreased \$1. Relationships were demonstrated between the dependent variable and both variables for students' residences. Students who resided in the states in which the institutions were located received $\$ 1,396$ more on average than foreign or international students. United States residents who did not reside in the states in which the institutions were located received $\$ 992$ more on average than foreign or international students. In addition, relationships were found between the independent variable and eight parents' education levels. Compared to students enrolled in other professional/technical programs, these students received the additional need-based financial aid displayed in Table 118.

Table 118: Equation 7a parent's educational level and changes in dependent variables

\begin{tabular}{|l|l|}
\hline Parent's Education Level & Change in Dependent Variable \\
\hline Did not complete high school & $\$ 727.77$ \\
\hline Did not know parent's education level & $\$ 628.89$ \\
\hline Less than two years of college & $\$ 436.04$ \\
\hline High school diploma or equivalent & $\$ 389.84$ \\
\hline 2 or more years of college but no degree & $\$ 363.32$ \\
\hline Vocational or technical training & $\$ 261.53$ \\
\hline Associates' degree & $\$ 236.77$ \\
\hline Bachelor's degree & $\$ 164.54$ \\
\hline
\end{tabular}

$H_{7 b}$ : Relationship between the amount of federal grants, veteran, and tax benefits received per student by private institutions, the amount of tuition and fees per student charged to in-state students, student characteristics, and the economic and political characteristics of the states.

The results of this equation indicate that relationships exist between the dependent variable and tuition and fees, student ages, students' genders, adjusted gross income and students' statuses as veterans. For every $\$ 100$ increase in tuition and fees, federal need-based grant aid increased \$4. As students' ages increased, the level of federal financial aid decreased. Male students received $\$ 102$ more federal financial grant aid on average than female students. 
For every $\$ 1,000$ decrease in adjusted gross income, federal financial aid increased $\$ 14$. Students who were not veterans received $\$ 1,161$ less federal financial aid than other students. In addition, relationships were demonstrated between the dependent variable and both variables for students' residences. Students who resided in the states in which the institutions were located received $\$ 1,159$ more on average than foreign or international students. United States residents who did not reside in the states in which the institutions were located received $\$ 1,061$ more on average than foreign or international students. Relationships were also found between the independent variable and nine parents' education levels. Compared to students enrolled in other professional/technical programs, these students received the additional need-based financial aid displayed in Table 119.

Table 119: Equation 7b parent's education level and changes in dependent variables

\begin{tabular}{|l|l|}
\hline Parent's Education Level & Change in Dependent Variable \\
\hline Did not know parent's education level & $\$ 831.25$ \\
\hline Did not complete high school & $\$ 778.06$ \\
\hline Less than two years of college & $\$ 635.07$ \\
\hline High school diploma or equivalent & $\$ 610.15$ \\
\hline 2 or more years of college but no degree & $\$ 538.51$ \\
\hline Associates' degree & $\$ 467.88$ \\
\hline Vocational or technical training & $\$ 428.50$ \\
\hline Bachelor's degree & $\$ 347.58$ \\
\hline Master's degree or equivalent & $\$ 221.24$ \\
\hline
\end{tabular}

$H_{7 c}$ : The amount of federal grants, veterans and tax benefits received per student at public institutions was less than or equal to the amount of federal grants, veterans and tax benefits received per student at private institutions

The mean federal financial grant aid per student received at public institutions was $\$ 958$ compared to $\$ 1452$ at private institutions. It appears that the amount of federal need-based aid 
provided to students at public and private schools is related to the relationship between the tuition and fee amounts charged to students.

$H_{8 a}$ : Relationship between tuition and fees minus all grants, veteran, and tax benefits for instate students enrolled at public institutions and adjusted gross income

A significant relationship was indicated between the dependent variable for this equation and the independent variable. Tuition and fees minus all grants, veteran, and tax benefits increased $\$ 11$ for every $\$ 1,000$ increase in adjusted gross income.

$H_{8 b}$ : Relationship between tuition and fees minus all grants, veteran, and tax benefits for instate students enrolled at private institutions and adjusted gross income

A significant relationship was indicated between the dependent variable for this equation and the independent variable. Tuition and fees minus all grants, veteran, and tax benefits increased $\$ 30$ for every $\$ 1,000$ increase in adjusted gross income. Tuition and fees minus all grants, veteran, and tax benefits increased $\$ 30$ for every $\$ 1,000$ increase in adjusted gross income.

$H_{8 c}$ : The amount of tuition and fees minus all grants, veteran, and tax benefits for in-state students at public institutions was less than or equal to the amount of tuition and fees minus all grants, veteran, and tax benefits for in-state students at private institutions

The mean amount of tuition and fees minus all grants, veteran, and tax benefits for instate students at public institutions was $\$ 1,027$ compared to $\$ 6,193$ for students at private institutions. It appears this difference is related to the relationship between the tuition and fee amounts charged to students. 
$H_{8 d:}$ Relationship between tuition and fees minus all grants, veteran, and tax benefits for outof-state students enrolled at public institutions and adjusted gross income

A significant relationship was indicated between the dependent variable for this equation and the independent variable. Tuition and fees minus all grants, veteran, and tax benefits increased $\$ 30$ for every $\$ 1,000$ increase in adjusted gross income.

$H_{8 e}$ : There is no significant relationship between tuition and fees minus all grants, veteran, and tax benefits for out-of-state students enrolled at private institutions and adjusted gross income

A significant relationship was indicated between the dependent variable for this equation and the independent variable. Tuition and fees minus all grants, veteran, and tax benefits increased $\$ 59$ for every $\$ 1,000$ increase in adjusted gross income.

$H_{8 f}$ : The amount of tuition and fees minus all grants, veteran, and tax benefits for out-of-state students at public institutions was less than or equal to the amount of tuition and fees minus all grants, veteran, and tax benefits for out-of-state students at private institutions

The mean amount of tuition and fees minus all grants, veteran, and tax benefits for out-of state students at public institutions was $\$ 5,192$ compared to $\$ 11,015$ for out-of-state students at private institutions. It appears this difference is related to the relationship between the tuition and fee amounts charged to students.

Figure 3 displays the level of adjusted gross income versus tuition minus grants, veterans' benefits and tax benefits. Separate calculations are provided for in-state and out-of state students at public and private institutions. Higher income students at public universities pay less tuition than students at private schools. This is true for both in-state and out-of-state students although the gap is greater for in-state students. Low or no-income students who enroll at private 
institutions pay more than high-income students pay at public schools. These data reflect the merit-based financial aid that students received. In some circumstances, the value that very capable, high income students provide to institutions may be reflected in low net payments.

Figure 3: Adjusted gross income versus tuition minus grants, veterans and tax benefits

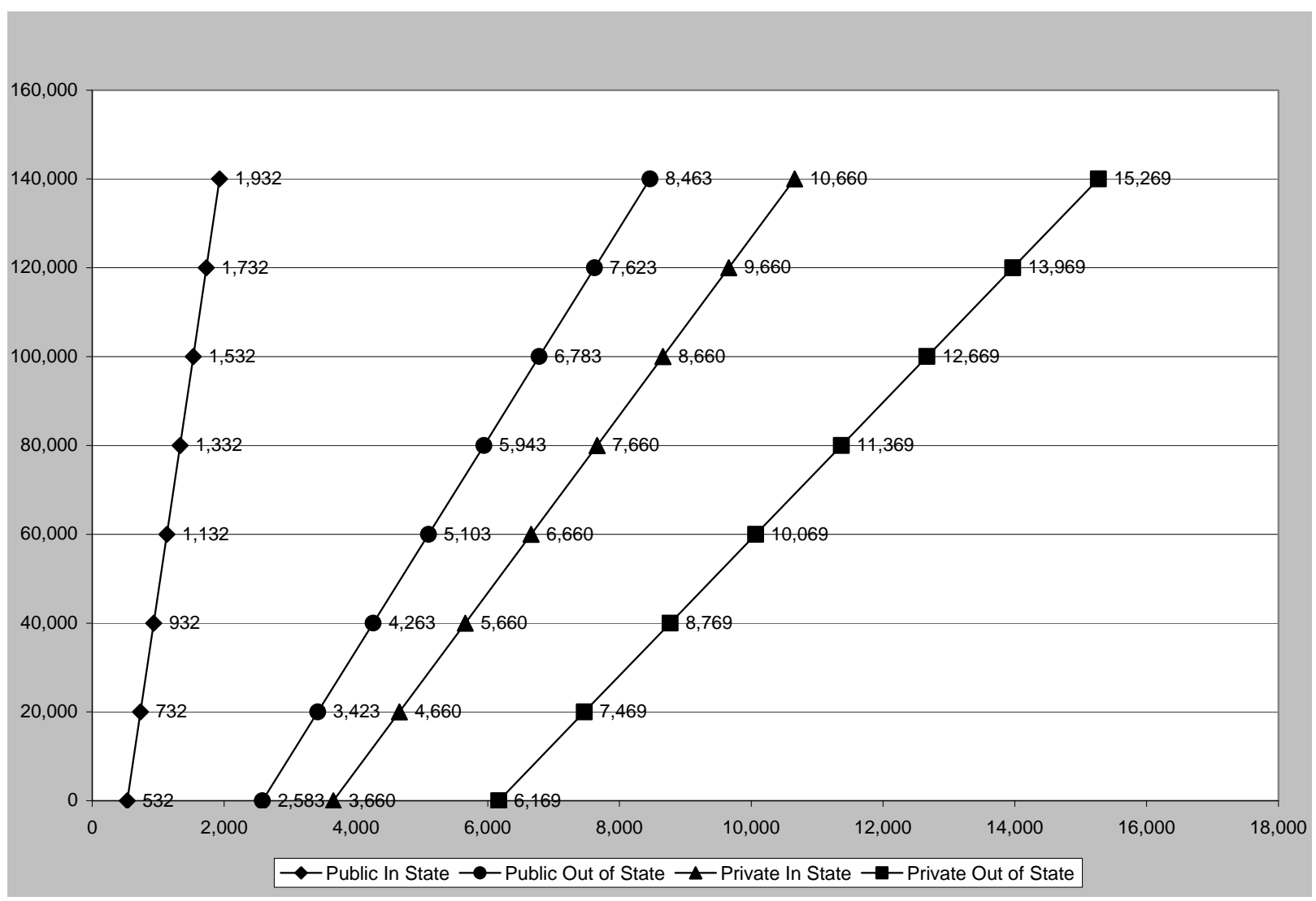

\section{Conclusions}

The results of this study demonstrate that governmental expenditures for human capital are allocated inefficiently. For the purposes of this study, the mean amount for tuition and fees minus grants and tax benefits at private institutions represents the higher education market value. The mean amount paid by students enrolled at public institutions for tuition and fees minus grants and tax benefits at all income levels is less than that paid by students enrolled at private 
institutions. Students from families of all income levels pay less than market rates for public higher education.

Although the tuition charges minus grants and tax benefits for students enrolled at public institutions do not coincide with market rates, the magnitude of the differences between public and private institutions is greater at higher income levels. For example, the difference between the tuition charges minus grants and tax benefits paid by students enrolled at public and private institutions is $\$ 2,691$ at the $\$ 20,000$ family income level. The difference at the $\$ 140,000$ income level is $\$ 6,531$. The slopes of the lines in figure 3 are for the public institutions are steeper than the slopes of the lines for private institutions. This indicates that the amounts paid by affluent families for public higher education compared to the amounts paid by less affluent families is inequitable.

To make this determination, it was necessary to understand the public higher education historical context, price discrimination in higher education and the markets in which institutions operate. The majority of public institutions were founded to educate the working class and produce teachers for primary and secondary education. It was believed that educated citizens in turn would promote the economic development of the state. As a result, tuition and fees are usually maintained at low levels for all citizens.

Appropriations are made to public institutions to pay expenses that tuition revenues do not cover. Because students from affluent families pay the same tuition as other students, this system is inequitable. States do not experience significant economic development benefits by paying for an education for which a student's family is willing and able to pay. 
An analysis of public higher education tuition is complicated by the existence of financial aid. Because the actual amount paid to a given institution may vary for different students, researchers have theorized that schools engage in price discrimination.

The existence of multiple markets complicates the analysis of price discrimination. Students with certain characteristics are valuable to colleges and universities. As a result, institutions provide for free or at reduced costs for high performing or needy students. It is useful to view this exchange as a separate market in which institutions are buyers. In addition, governmental entities provide financial aid to students to promote economic development. The federal government also provides revenues directly to colleges and universities. Finally, institutions provide donors with philanthropic opportunities. This study identifies five markets: Market for Educational Services;

Market for Value Provided to Contributors;

Market for Value Provided to Governments;

Market to Attract Students with Certain Characteristics; and Market to Provide Governmental Funds to Students

By comparing these markets for public and private institutions, it is possible to determine if the funding of public institutions is inefficient. In the market for instructional services, in-state students were charged $\$ 4,429$ for tuition on average by public institutions compared to $\$ 17,420$ for private institutions. The amount of tuition and fees charged by public institutions is significantly less than the amounts charged by private schools at all family income levels. Furthermore, as institutions become more selective and rise in Carnegie Foundation Classification, tuition becomes more expensive. The political influence of legislatures on public tuition and fees was demonstrated by this study. It appears that tuition and fees are set at low 
rates to ensure that higher education is affordable for all citizens. By establishing uniformly low rates for students from all income levels, state governments may forego revenues from students who are able to pay higher amounts. This is not an efficient use of resources for economic development.

Governmental appropriations to public colleges and universities may not efficiently support economic development. The effect of establishing different tuition charges for students at different family income levels is not known. These state subsidies may support some students whose parents may be willing to pay more for their education if the schools received fewer appropriations. Limited economic development benefits are realized from expenditures that would have been made from another source.

The strongest predictor for governmental appropriations is depreciation expense per student. Instead of funding institutions to promote certain programs, states may predicate funding on institutions' current financial status. Appropriations may be made to support schools that do not efficiently meet the economic development requirements of the state.

The amount of depreciation expenses per student is also a strong predictor for donations made to both public and private institutions. As noted in Chapter 3, depreciation is the systematic allocation of the historical cost of an asset over its useful life. Depreciation is calculated for all physical assets except for land. Because this cost is not adjusted for inflation, it is difficult to determine the real value of an institution's physical assets. A building of significant value that was constructed more than 50 years ago may not be depreciated because its useful life for accounting purposes may have expired. On the other hand, a recently constructed building may have a higher depreciation expense amount in relation to its real value because of its higher cost. The results of the econometric equations demonstrate that revenue sources are willing to pay 
more for attributes that are predicted by the per student allocation of an institution's capital expenditures over the useful life of its physical assets.

Depreciation expense per student may represent an institution's wealth in terms of physical assets, unadjusted for inflation. Further research is necessary to determine the nature and age of institutions physical assets.

Other attributes may be related to depreciation expense. For example, a well managed institution may be more likely to accumulate physical assets and attract revenues from the sources mentioned above. Some governments may provide additional appropriations for operating costs when new buildings are constructed. New buildings may attract more students. Additional research is necessary to determine institutional attributes that predict a higher level of depreciation expense per student. This may provide insight into the relationship of depreciation expense per student and the revenue sources identified in this study.

Private institutions received more than ten times the amount of donations that public institutions receive. Perhaps, public institutions have historically relied on state appropriations in lieu of private support. In addition, private donors may not believe that these schools should not need private funds if they receive appropriations from the state.

To increase private donations, public institutions may need additional support from state governments. It may be necessary to build the wealth of some institutions to convince donors that these schools are successful and deserve their contributions. Donors may view their contribution as an investment. They want to see their donations used for the greatest benefit by organizations that will remain in existence.

For the equations related to student reception of financial aid, the coefficient of determination $\left(r^{2}\right)$ value is less than the equations related to direct institutional funding. The 
number of participants in these financial aid markets is much higher than the direct institutional funding markets. The marketing ability of an individual student may diminished by the sheer number of competitors. No research was found in the literature review that studied the relative marketing power of students. Although the existence of these financial aid markets diminishes the claim of price discrimination, the relatively low correlations indicate that institutions may engage in price discrimination.

\section{Recommendations}

The econometric model developed in this study should be used as a tool for strategic planning. It provides a framework for the planning of school's development of positions in the five markets. Rather than viewing donors and governments as benefactors, schools see them as customers who want value for the money they pay. From this viewpoint, institutions can develop strategic plans that will increase revenues from these sources. By understanding the purpose of financial aid, colleges and universities can more equitably allocate the resources used to attract students with certain characteristics.

To increase the equity of higher education markets, public tuition and fee charges should be set at market rates. This will allow public institutions to target state appropriations and financial aid to provide more assistance to needy students. The gap between the tuition and fees paid minus grants and tax benefits should be the same for all students. Sufficient need-based financial aid should be awarded to ensure equity in the amounts that families pay for higher education.

If colleges and universities charge a market price to students from affluent families, they may be able to demonstrate that state appropriations are being used more equitably. Legislators 
may be willing to appropriate more money to schools if it is used more equitably to promote economic development.

To maintain academic quality, public institutions will need to provide merit-based financial aid to capable students. These students may be able to afford to pay for their educations without any financial assistance.

It may not be productive to provide state merit-based financial aid to large numbers of state residents. If many affluent families would attend public institutions and pay the tuition and fees anyway, these funds may be wasted. It may be more productive to provide need-based financial aid to needy students who demonstrate that they have the basic foundations to succeed in higher education.

It may be useful for public institutions to use state appropriations to fund need-based financial aid only. In this circumstance, tuition and fees, contributions and auxiliary revenues would be used to finance other institutional costs. The tuition and fee rates should be set at a high enough level to fund the associated operational costs of the institutions. This model would provide a more direct flow of state government resources to students.

Colleges and universities should be aware of the markets that they operate in. Strategic plans can be constructed within the market framework identified in this study. As demonstrated by the results of the econometric equations, each market has unique characteristics that may be exploited. A successful institution will respond effectively to the needs of each market.

Because policy makers do not view higher education economics through this study's market theory, it is difficult for them to address affordability issues. Public higher education institutions may increase costs in response to the demands of affluent students who attend their institutions. These students may expect quality instructional services and facilities. It is likely 
that these students are sought because they are often more capable than lower income students.

On the other hand, policy makers focus on making tuition affordable for low-income students. It is important for institutions and policy makers to understand that public institutions must serve low-income students and also attract capable students.

Institutions should be aware that an increase in revenues in one market may influence the amount of revenues collected in another market. For example, public colleges and universities may increase their wealth through the receipt of additional governmental appropriations. If these funds are expended wisely, students may be willing to pay higher tuition and fee rates. Donors may be willing to increase contributions if they see that governments and students perceive the value that an institution provides. Governments and students may be willing to provide additional revenues if donors provide more assistance to a college or university.

The federal revenues received by some institutions for their land grant status is not consistently reported. These revenues may be combined with other federal appropriations or federal operating revenues. It would be useful to report these revenues as a discrete item on institutions' financial statements to give a clearer understanding of their federal revenues.

\section{Why Changes May Not Be Accepted}

The recommendations listed above may be very difficult to implement. Elected officials may receive significant campaign contributions wealthier individuals. If the benefit of low tuition is removed from these voters, elected officials may experience a reduction in campaign funds. It would be necessary to educate voters about the effects of current policy and the need for change. The economic concepts are complex and difficult to understand. It would not be hard to 
discredit such a change prior to an election. Although the change would reduce benefits for the wealthy in the short run, the long-term benefits for all citizens would outweigh that reduction.

Even if elected officials are successful in changing tuition policy, public higher education institutions may object to a change. Marketing efforts may be disrupted. Wealthier families may choose to go to private schools if the tuition is comparable. These institutions may fear a reduction in enrollments resulting from the increased tuition prices.

Other state priorities may prevent change. Some state leaders may want to ensure that a large number of high school graduates attend college within their states. They may believe that students are more likely to reside in the same states where they attend college. These leaders may also want to keep out-of-state tuition low to import individuals who become college graduates.

Although affluent families should be able to afford higher tuition, they have probably not anticipated a significant increase in the levels of tuition and fees. If these families do not save a significant portion of their income, they may not have sufficient liquid assets to finance their childrens' educations. It may be difficult for them to finance their children's college educations. A graduated increase over a period of years would permit these families to adjust their college savings plans.

\section{Recommendations for Further Research}

The need for further research is indicated in several areas. Although depreciation expense per student was a significant predictor for several of the revenue sources, the nature of the relationship is difficult to determine. Research to identify determinants of deprecation expenses per student and age of institutions' depreciable assets may provide insight into this relationship. 
Donations may be a function of the amount of resources institutions expend to encourage contributors to give to their schools. Unfortunately, data regarding these expenditures is not easily attainable for public institutions. If the NCES would require public institutions to provide these data, the effect of fundraising expenditures on results could be explored.

The standards for reporting of federal revenues related to institutions' land grant statuses are not clear. These revenues may be included in federal appropriations or federal operating revenues. A study to determine how institutions report these data would be useful.

Additional research of the five markets identified in this study would provide useful information about higher education economics. Longitudinal studies of the markets would provide information about their activities over time and provide insight into the volatility of the markets. Studies of individual markets would give in-depth analyses that were not part of this study.

It would be useful to perform a study of federal revenues provided to land grant institutions. Data from this research could be used to inform financial reporting policy reporting for these revenues. In addition, the economic development benefits of these revenues should be measured

This study did not include auxiliary and hospital revenues. To obtain a more complete picture of higher education economics, the markets providing these revenues should be explored. The relationship of institutional and student borrowing and this economic model should be explored. Institutions with certain characteristics may receive financial resources from lenders. Students also receive loans based on their characteristics. 


\section{Concluding Remarks}

Although it may be difficult to change the tradition of low tuition and fee levels for all students at public institutions, it may be possible in certain circumstances. As frustration levels rise with the cost of education, economic developments may force the review of new perspectives. The number of new revenues sources is limited. The availability of money for student loans is becoming a problem. By increasing tuition and fees to market levels and providing financial aid to needy students, states can increase the equity of their spending on higher education. As a result, more human capital may be developed at a lower cost. 


\section{References}

Addis, C. (2003). Jefferson's Vision For Education, 1760-1845. New York: Peter Lang Publishing.

Archibald, R. B. (2002). Redesigning the financial aid system: why colleges and universities should switch roles with the federal government. Baltimore, Md.: The Johns Hopkins University Press.

Archibald, R. B., \& Feldman, D. H. (2006). State Higher Education Spending and the Tax Revolt. The Journal of Higher Education, 77(4), 26.

Avery, C., \& Kane, T. J. (2004). Student Perceptions of College Opportunities. In C. M. Hoxby (Ed.), College Choices: The economics of where to go, when to go, and how to pay for it. Chicago: The University of Chicago Press.

Baade, R. A., \& Sundberg, J. O. (1996). What determines alumni generosity. Economics of Education Review, 15(1), 7.

Baum, S., \& Sjogren, J. (1996). The Distribution of Subsidies to Postsecondary Students. Eastern Economic Journal, 22(2), 10.

Boatman, A., \& L'Orange, H. (2006). State Tuition, Fees, and Financial Assistance Policies for Public Colleges and Universities, 2005-06. Boulder, Co.: State Higher Education Executive Officers.

Bowden, R. G., \& Elrod, H. E. (2004). State Lotteries: Their Effect on Equal Access to Higher Education. Journal of Hispanic Higher Education, 3(1), 12.

Bowen, W. G., \& Breneman, D. W. (1993). Student aid. Brookings Review, 11(1), 4.

Caminole, M., Siegel, P., Dudley, K., Roe, D., \& Gilligan, T. (2006). 2004 National Postsecondary Student Aid Study (NPSAS: 04) Full-Scale Methodology Report. Washington, D.C: National Center for Education Statistics.

Carroll, K., \& Coates, D. (2001). Teaching Price Discrimination: Some Clarification. Southern Economic Journal, 66(2), 466-480.

Clotfelter, C. T. (2003). Alumni giving to elite private colleges and universities. Economics of Education Review, 22(2), 12.

College Savings Plan Network. (N.D.). General Information Retrieved March 13, 2007, 2007, from http://www.collegesavings.org/planning/general.htm

Courant, P. N., McPherson, M., \& Resch, A. M. (2006). The Public Role of Higher Education. National Tax Journal, LVIV(2), 27.

Cunningham, B. M., \& Cochi-Ficano, C. K. (2002). The determinants of donative revenue flows from alumni of higher education. The Journal of Human Resources, 37(3), 30.

Day, J. C., \& Newburger, E. C. (2002). The Big Payoff: Educational Attainment and Synthetic Estimates of Work-Life Earnings. Retrieved. from http://www.census.gov/prod/2002pubs/p23-210.pdf.

Doti, J. L. (2004). Is Higher Education Becoming a Commodity. Journal of Higher Education Policy and Management, 26(3), 363-369.

Douglass, J. A. (2000). The California idea and American higher education: 1850 to the 1960 master plan. Stanford, California: Stanford University Press.

Edmond, J. B. (1978). The Magnificent Charter: The Origin and Role of the Morrill Land-Grant Colleges and Universities (1st ed.). Hicksville, N.Y.: Exposition Press.

Education, P. s. C. o. H. (1947). Higher Education for American Democracy. New York: Harper $\&$ Brothers. 
Ehrenberg, R. G., \& Smith, C. L. (2003). The sources and uses of annual giving at selective private research universities and liberal arts colleges. Economics of Education Review, 22(r3), 13.

Garratt, R., \& Marshall, J. M. (1995). Optimum College Admissions, Taxes and Tuitions when Completion is uncertain. Education Economics, 3(3), 16.

Gottfried, M. A., \& Johnson, E. L. (2006). Solicitation and donation: An econometric evaluation of alumni generosity in higher education Unpublished Research Paper. University of Pennsylvania.

The Investment Payoff, A 50-State Analysis of the Public and Private Benefits of Higher Education. (2005).). Washington, D.C: The Institute for Higher Education Policy.

Jefferson Quotations. (N.D.). Retrieved 11/22/2006, 2006, from http://www.monticello.org/reports/quotes/education.html

Johnstone, B. (2002). Challenges of Financial Austerity: Imperatives and limitations of Revenue Diversification. The Welsh Journal of Education, 11(1), 18.

Jones, D., et al. (2003). Policies in Sync: Appropriations, Tuition, and Financial Aid for Higher Education. Retrieved 3/25/2007. from http://wiche.edu/policy/Changing Direction/pubs.htm.

Kane, T. J. (1999). The Price of Admission: Rethinking how Americans pay for College. Washington, D.C: Brookings Institution Press.

Kennedy, P. (1998). A guide to Econometrics (4 ed.). Cambridge, Massachusetts: The MIT Press.

Kim, M. H. (2004). The Determinants of Institutional Financial Aid and its Effect on Degree Completion: The Difference Between Students at Public and Private Four-Year Institutions. Unpublished Dissertation, Columbia University, New York.

Koshal, R. K., \& Koshal, M. (2000). State appropriations and higher education tuition: what is the relationship? Education Economics, 8(1), 9.

The Land-Grant Tradition Morrill Act. (N.D.). Retrieved November 22, 2006, 2006, from http://www.nasulgc.org/publications/Land Grant/LGTrad FirstMorrillAct.htm

The Land Grant Tradition: A Chronology of Federal Legislation Affecting Public Higher Education. (N.D.). Retrieved 11/16/2006, 2006, from http://www.nasulgc.org/publications/Land_Grant/Chronology.htm

Lawson, R. A., \& Zerkle, A. (2006). Price Discrimination in College Tuition: An Empirical Case Study. Journal of Economics and Finance Education, 5(1), 7.

Lehtonen, R., \& Pahkinen, E. (2004). Practical Methods for Design and Analysis of Complex Surveys (2nd ed.). Chichester, England: John Wiley \& Sons.

Lowry, R. C. (1999). The effects of political interests and campus outputs on public university revenues. Economics of Education Review, 20(2), 15.

Lowry, R. C. (2001). Governmental structure, trustee selection, and public university prices and spending; multiple means to similar ends. American Journal of Political Science, 45(4), 18.

Lucas, C. J. (2006). American Higher Education. New York: Palgrave Macmillan.

Marudas, N. P., \& Jacobs, F. A. (2004). Determinants of Charitable Donations to Large U.S. Higher Education, Hospital, and Scientific Research NPOs: New Evidence from Panel Data. International Journal of Voluntary and Nonprofit Organizations, 15(2), 23.

Measuring Up 2006. (2006).). Indianapolis, IN: The National Center for Public Policy and Higher Education. 
Miller, C., et al. (2006). A Test of Leadership: Charting the Future of U.S. Higher Education. Retrieved. from http://www.ed.gov/about/bdscomm/list/hiedfuture/reports/pre-pubreport.pdf.

Nerlove, M. (2001). On Tuition and the Costs of Higher Education: Prolegomena to a Conceptual Framework. Journal of Political Economy, 80(3), 41.

Ogren, C. A. (2005). The American State Normal School. New York: Palgrave Macmillan.

Percent Distribution of State and Local Government General Expenditures. (2006). In FB15 16.XLS (Ed.), Microsoft Excel. Atlanta, GA: Southern Regional Education Board.

Percent of Median Family Incomes Required to Pay Median Annual Tuition and Fees. (2006). In FB51_52_53.XLS (Ed.). Atlanta, GA: Southern Regional Education Board.

Rose, D. C., \& Sorensen, R. L. (1992). High tuition, financial aid, and cross-subsidization: Do needy students really benefit? Southern Economic Journal, 59(1), 11.

Rothschild, M., \& White, L. J. (1995). The Analytics of the Pricing of Higher Education and Other Services in Which the Customers are Inputs. Journal of Political Economy, 103(3), 573-586.

Singell, L. D., \& Stone, J. A. (2007). For whom the Pell tolls: The response of university tuition to federal grants-in-aid. Economics of Education Review, 26(3), 11.

Thelin, J., R. (2004). A History of American Higher Education. Baltimore, Md.: The Johns Hopkins University Press.

Tiffany, F. G., \& Ankrom, J. A. (1998). The competitive use of price discrimination by colleges. Eastern Economic Journal, 24(1), 12.

United States Department of the Treasury. (N.D). History of the U.S. Tax System. Education Retrieved July 29,2007, 2007, from http://www.ustreas.gov/education/factsheets/taxes/ustax.shtml

Vedder, R. K. (2004). Going Broke By Degree: Why College Costs too much. Washington, D.C.: American Institute for Public Policy Research.

Williams, J. R., \& Carcello, J. V. (2004). Miller GAAP Guide. New York: Aspen Publishers.

Winston, G., C. (2003). Toward a Theory of Tuition: Prices, Peer Wages, and Competition. Williamstown, MA 01267: Williams College.

Wolanin, T. R. (2001). Rhetoric and Reality: Effects and Consequences of the HOPE Scholarship (Working Paper). Washington, D.C: The Institute for Higher Education Policy. 


\section{Appendix A}

\section{$\underline{\text { Table A. Variables }}$}

\begin{tabular}{|c|c|c|c|}
\hline \multicolumn{4}{|c|}{ Variables } \\
\hline \begin{tabular}{|l|} 
Variable \\
Number
\end{tabular} & \begin{tabular}{|c|} 
Equation \\
Variable Name
\end{tabular} & Variable Label & Variable Type \\
\hline 1 & TPBI & In-state tuition and fees per student charged by public institutions & Dependent \\
\hline 2 & TPVI & In-state tuition and fees per student charged by private institutions & Dependent \\
\hline 3 & TPBO & Out-of-state tuition and fees per student charged by public institutions & Dependent \\
\hline 4 & TPVO & Out-of-state tuition and fees per student charged by private institutions & Dependent \\
\hline 5 & DONPB & Total amount of revenues collected from private donations per student for public institutions & Dependent \\
\hline 6 & DONPV & Total amount of revenues collected from private donations per student for private institutions & Dependent \\
\hline 7 & APPPB & Per student state government appropriations made to public institutions & Dependent \\
\hline 8 & APPPV & Per student state government appropriations made to private institutions & Dependent \\
\hline 9 & FRPB & Federal operating revenues provided per student to public institutions & Dependent \\
\hline 10 & FRPV & Federal operating revenues provided per student to private institutions & Dependent \\
\hline 11 & IFPBM & Institutional merit-based financial aid paid by public institutions & Dependent \\
\hline 12 & IFPVM & Institutional merit-based financial aid paid by private institutions & Dependent \\
\hline 13 & IFPBN & Institutional need-based financial aid paid by public institutions & Dependent \\
\hline 14 & IFPVN & Institutional need-based financial aid paid by private institutions & Dependent \\
\hline 15 & SFPBM & State merit-based financial aid paid to students enrolled at public institutions & Dependent \\
\hline 16 & SFPVM & State merit-based financial aid paid to students enrolled at private institutions & Dependent \\
\hline 17 & SFPBN & State need-based financial aid paid to students enrolled at public institutions & Dependent \\
\hline 18 & SFPVN & State need-based financial aid paid to students enrolled at private institutions & Dependent \\
\hline 19 & FFPB & Federal grant aid per student enrolled at public institutions & Dependent \\
\hline 20 & FFPV & Federal grant aid per student enrolled at private institutions & Dependent \\
\hline 21 & TGVTBPBI & Tuition and fees minus all grants, veteran, and tax benefits for in-state students enrolled at public institutions & Dependent \\
\hline 22 & TGVTBPVI & Tuition and fees minus all grants, veteran, and tax benefits for in-state students enrolled at private institutions & Dependent \\
\hline 23 & TGVTBPBO & Tuition and fees minus all grants, veteran, and tax benefits for out-of-state students enrolled at public institution & Dependent \\
\hline 24 & TGVTBPVO & Tuition and fees minus all grants, veteran, and tax benefits for out-of-state students enrolled at private institutio & Dependent \\
\hline 25 & SE & Selectivity of the institution & Independent Dummy \\
\hline 26 & $\mathrm{CC}$ & Carnegie Foundation classification & Independent Dummy \\
\hline 27 & CR & Per-capita tax revenue for the state in which the school is operated & Independent \\
\hline 28 & DEM & Political power in the legislature & Independent Dummy \\
\hline 29 & DEPRPB & Public Institution annual depreciation expense per student & Independent \\
\hline 30 & DEPRPV & Private institution annual depreciation expense per student & Independent \\
\hline 31 & PUB & Institutional control & Independent Dummy \\
\hline 32 & PROGI & Institution's enrollments by program obtained from IPEDS data & Independent \\
\hline 33 & PROGN & Institution's enrollments by program obtained from NPSAS:04 data & Independent \\
\hline 34 & $\mathrm{R}$ & Current enrollment as a percentage of the sum of the high-school graduates for the past 4 years & Independent \\
\hline 35 & $2 Y$ & Percentage of students enrolled in two-year colleges & Independent \\
\hline 36 & STAT62 & Institution's status as an 1862 Land grant institution & Independent Dummy \\
\hline 37 & STAT90 & Institution's status as an 1890 Land grant institution & Independent Dummy \\
\hline 38 & $\mathrm{~T}$ & Tuition and fee charges per student & Independent \\
\hline 39 & SA & Age & Independent \\
\hline 40 & SAGI & Adjusted gross income & Independent \\
\hline 41 & SR & Race & Independent Dummy \\
\hline 42 & SG & Gender & Independent Dummy \\
\hline 43 & SPEL & Parents' education level & Independent Dummy \\
\hline 44 & SGPA & Grade point average & Independent \\
\hline 45 & SVA & Veteran status & Independent Dummy \\
\hline 46 & LOC & State of residency status in relation to institution location & Independent Dummy \\
\hline
\end{tabular}




\section{Appendix B: IPEDS Data Selection Criteria}

The IPEDS data were obtained through the Dataset Cutting Tool ("DCT) provided by NCES. The DCT website is http://nces.ed.gov/ipedspas/. Separate data populations were selected for public institutions and private non-profit institutions combined, public institutions, private non-profit institutions, and two-year institutions. The selection criteria for each data population are provided below.

\section{Public institutions and private non-profit institutions}

\section{Data selection criteria:}

Year of school universe: 2004

Collection year of data selected: 2004

Imputation flags selected: No

Search criteria used:

U.S. only: Alabama, Alaska, Arizona, Arkansas, California, Colorado, Connecticut, Delaware, District of Columbia, Florida, Georgia, Hawaii, Idaho, Illinois, Indiana, Iowa, Kansas, Kentucky, Louisiana, Maine, Maryland, Massachusetts, Michigan, Minnesota, Mississippi, Missouri, Montana, Nebraska, Nevada, New Hampshire, New Jersey, New Mexico, New York, North Carolina, North Dakota, Ohio, Oklahoma, Oregon, Pennsylvania, Rhode Island, South Carolina, South Dakota, Tennessee, Texas, Utah, Vermont, Virginia, Washington, West Virginia, Wisconsin, Wyoming, Type of institution:

- $\quad$ Public, 4-year or above

- $\quad$ Private not-for-profit, 4-year or above

Geographic region:

- $\quad$ New England CT ME MA NH RI VT

- $\quad$ Mid East DE DC MD NJ NY PA

- $\quad$ Great Lakes IL IN MI OH WI

- $\quad$ Plains IA KS MN MO NE ND SD

- $\quad$ Southeast AL AR FL GA KY LA MS NC SC TN VA WV

- $\quad$ Southwest AZ NM OK TX

• $\quad$ Rocky Mountains CO ID MT UT WY

- $\quad$ Far West AK CA HI NV OR WA

Title IV participating:

- $\quad$ Participates in Title IV federal financial aid programs

- Branch campus of a main campus that participates in Title IV Carnegie Classification 2000:

- Doctoral/Research Universities--Extensive

- Doctoral/Research Universities--Intensive

- Masters Colleges and Universities I

- Masters Colleges and Universities II

- Baccalaureate Colleges--Liberal Arts

- Baccalaureate Colleges--General

- Baccalaureate/Associates Colleges 
Postsecondary and Title IV institution indicator (Ed Tab universe):

- $\quad$ Title IV postsecondary institution

UnitIds Selected: All UnitIDs were selected.

UNITID-Unique ID for Each Institution (entity)

INSTNM-Institution (entity) name

IDX_EF - ID number of parent institution - Enrollment

UNITID number of parent institution reporting enrollment data. IDX_EF contains the UNITID number of the parent institution. This data field is used to link child institutions with the parent institution.

Data type-Numeric

IDX_F - ID number of parent institution - Finance

UNITID number of parent institution reporting Finance data IDX_F contains the UNITID number of the parent institution. This data field is used to link child institutions with the parent institution.

Data type-Numeric

\section{Public Institutions:}

\section{Data selection criteria:}

Options:

Year of school universe: 2004

Collection year(s) of data selected: 2004

Imputation flags selected: No

Search criteria used: U.S. only: Alabama, Alaska, Arizona, Arkansas, California, Colorado, Connecticut, Delaware, District of Columbia, Florida, Georgia, Hawaii, Idaho, Illinois, Indiana Iowa, Kansas, Kentucky, Louisiana, Maine, Maryland, Massachusetts, Michigan, Minnesota Mississippi, Missouri, Montana, Nebraska, Nevada, New Hampshire, New Jersey, New Mexico New York, North Carolina, North Dakota, Ohio, Oklahoma, Oregon, Pennsylvania, Rhode Island South Carolina, South Dakota, Tennessee, Texas, Utah, Vermont, Virginia, Washington, West Virginia, Wisconsin, Wyoming

Type of institution:

Private not-for-profit, 4-year or above

Geographic region:

New England CT ME MA NH RI VT

Mid East DE DC MD NJ NY PA

Great Lakes IL IN MI OH WI 
Plains IA KS MN MO NE ND SD

Southeast AL AR FL GA KY LA MS NC SC TN VA WV

Southwest AZ NM OK TX

Rocky Mountains CO ID MT UT WY

Far West AK CA HI NV OR WA

Title IV participating:

Participates in Title IV federal financial aid programs

Branch campus of a main campus that participates in Title IV

Carnegie Classification 2000:

Doctoral/Research Universities--Extensive

Doctoral/Research Universities--Intensive

Masters Colleges and Universities I

Masters Colleges and Universities II

Baccalaureate Colleges--Liberal Arts

Baccalaureate Colleges--General

Baccalaureate/Associates Colleges

Postsecondary and Title IV institution indicator (Ed Tab universe):

Title IV postsecondary institution

UNITID-Unique ID for Each Institution (entity)

INSTNM-Institution (entity) name

IDX_F - ID number of parent institution - Finance

UNITID number of parent institution reporting Finance data IDX_F contains the UNITID number of the parent institution. This data field is used to link child institutions with the parent institution.

Data type-Numeric

\section{Private Institutions:}

\section{Data selection criteria:}

Options:

Year of school universe: 2004

Collection year(s) of data selected: 2004

Imputation flags selected: No

Surveys/Selection(s):

2004 - Finance 
Search criteria used: U.S. only: Alabama, Alaska, Arizona, Arkansas, California, Colorado, Connecticut, Delaware, District of Columbia, Florida, Georgia, Hawaii, Idaho, Illinois, Indiana Iowa, Kansas, Kentucky, Louisiana, Maine, Maryland, Massachusetts, Michigan, Minnesota, Mississippi, Missouri, Montana, Nebraska, Nevada, New Hampshire, New Jersey, New Mexico New York, North Carolina, North Dakota, Ohio, Oklahoma, Oregon, Pennsylvania, Rhode Island South Carolina, South Dakota, Tennessee, Texas, Utah, Vermont, Virginia, Washington, West Virginia, Wisconsin, Wyoming

Type of institution:

Private not-for-profit, 4-year or above

Geographic region:

New England CT ME MA NH RI VT

Mid East DE DC MD NJ NY PA

Great Lakes IL IN MI OH WI

Plains IA KS MN MO NE ND SD

Southeast AL AR FL GA KY LA MS NC SC TN VA WV

Southwest AZ NM OK TX

Rocky Mountains CO ID MT UT WY

Far West AK CA HI NV OR WA

Title IV participating:

Participates in Title IV federal financial aid programs

Branch campus of a main campus that participates in Title IV

Carnegie Classification 2000:

Doctoral/Research Universities--Extensive

Doctoral/Research Universities--Intensive

Masters Colleges and Universities I

Masters Colleges and Universities II

Baccalaureate Colleges--Liberal Arts

Baccalaureate Colleges--General

Baccalaureate/Associates Colleges

Postsecondary and Title IV institution indicator (Ed Tab universe):

Title IV postsecondary institution

UNITID-Unique ID for Each Institution (entity)

INSTNM-Institution (entity) name

IDX_F - ID number of parent institution - Finance

UNITID number of parent institution reporting Finance data IDX_F contains the UNITID number of the parent institution. This data field is used to link child institutions with the parent institution. 
Data type-Numeric

\section{Two-Year Institutions:}

\section{Data selection criteria:}

Dataset Cutting Tool selection parameters:

Options:

Year of school universe: 2004

Collection year(s) of data selected: 2004

Imputation flags selected: No

Surveys/Selection(s):

2004 - Enrollments

Frequently used enrollment variables: Academic year 2003-04

Search criteria used: U.S. only:

Alabama, Alaska, Arizona, Arkansas, California, Colorado, Connecticut, Delaware, District of Columbia, Florida, Georgia, Hawaii, Idaho, Illinois, Indiana, Iowa, Kansas, Kentucky, Louisiana, Maine, Maryland, Massachusetts, Michigan, Minnesota, Mississippi, Missouri, Montana, Nebraska, Nevada, New Hampshire, New Jersey, New Mexico, New York, North Carolina, North Dakota, Ohio, Oklahoma, Oregon, Pennsylvania, Rhode Island, South Carolina, South Dakota, Tennessee, Texas, Utah, Vermont, Virginia, Washington, West Virginia, Wisconsin, Wyoming

Type of institution:

Public, 2-year

Geographic region:

New England CT ME MA NH RI VT

Mid East DE DC MD NJ NY PA

Great Lakes IL IN MI OH WI

Plains IA KS MN MO NE ND SD

Southeast AL AR FL GA KY LA MS NC SC TN VA WV

Southwest AZ NM OK TX

Rocky Mountains CO ID MT UT WY

Far West AK CA HI NV OR WA

Title IV participating:

Participates in Title IV federal financial aid programs

Branch campus of a main campus that participates in Title IV

Postsecondary and Title IV institution indicator (Ed Tab universe):

Title IV postsecondary institution

UNITID-Unique ID for Each Institution (entity) 
IDX_EF - ID number of parent institution - Enrollment

UNITID number of parent institution reporting enrollment data. IDX_EF contains the UNITID number of the parent institution. This data field is used to link child institutions with theparent institution.

Data type-Numeric 


\section{Appendix C: IPEDS Variables Used to Calculate Dissertation Variables}

Variable Name: FTE12MN

Variable Label: 12-month full-time equivalent enrollment: Academic year 2003-04

Description: The full-time-equivalent (FTE) enrollment used in this report is the sum of the institutions' FTE undergraduate enrollment and FTE graduate enrollment (as calculated from or reported on the 2004 Enrollment component) plus the estimated FTE of first-professional students. Undergraduate and graduate FTE are estimated using 12-month instructional activity (credit and/or contact hours). First-professional FTE is estimated by calculating the ratio of fulltime to part-time first-professional students from the fall counts (part A) and applying this ratio to the 12-month unduplicated headcount of first-professional students. The estimated number of full-time students is added to one-third of the estimated number of part-time students.

The calculation of FTE undergraduate and graduates is as follows:

Quarter calendar system

Enrollment level (One FTE over 12-month period)

Undergraduate 45 credit hours, 900 contact hours

Graduate 36 credit hours

Semester/trimester/4-1-4 plan/other calendar system

Enrollment level (one FTE over 12-month period)

Undergraduate 30 credit hours 900 contact hours

Graduate 24 credit hours

For institutions with continuous enrollment programs, FTE is determined by dividing the number of contact hours attempted by 900 .

Data type-N

Variable statistics for public institutions:

Number of records in query: 519

\begin{tabular}{|l|l|l|l|}
\hline Minimum & Maximum & Mean & Standard Deviation \\
\hline 170.00 & $53,274.00$ & $10,632.51$ & $9,417.86$ \\
\hline
\end{tabular}

Variable statistics for private institutions:

Number of records in query: 882

\begin{tabular}{|l|l|l|l|}
\hline Minimum & Maximum & Mean & Standard Deviation \\
\hline 77.00 & $36,888.00$ & $2,957.38$ & $3,866.33$ \\
\hline
\end{tabular}


These IPEDS variable FTE12MN used to calculate the following Dissertation variables:

DONPB Total amount of revenues collected form private donations per student for public institutions

DONPV Total amount of revenues collected form private donations per student for private institutions

APPPB Per student state government appropriations made to public institutions

APPPV Per student state government appropriations made to private institutions

FRPB Federal operating revenues provided per student to public institutions

FRPV Federal operating revenues provided per student to private institutions

DEPRPB Public institution depreciation expense per student

DEBRPV Private institution depreciation expense per student

$\mathrm{R} \quad$ Current enrollment as a percentage of the sum of the high-school graduates for the past four years

$2 \mathrm{Y} \quad$ Percentage of students enrolled in two-year colleges

For DONPB, DONPV, APPPB, APPPV, FRPB, FRPV, DEPRPB and DEPRPV, the institutional values for FTE12MN were divided into the above-listed variables associated with the dissertation variable. FTE12MN was totaled for each state and divided into the percent of high school graduates for each state to calculate the values for dissertation variable R. To determine the percentage of students enrolled in two-year colleges, FTE12MN was totaled for each state and divided by the two-year enrollments in each state. The source for two-year enrollments is described in the definition for variable 30 in Appendix C.

\section{Variable Name: ENRUNDUP}

Variable Label: 12-month unduplicated headcount: 2003-04

Description: Indicates how many individuals the institution served over a 12-month period (the unduplicated headcount) Unduplicated count - The sum of students enrolled for credit with each student counted only once during the reporting period, regardless of when the student enrolled. Credit - Recognition of attendance or performance in an instructional activity (course or program) that can be applied by a recipient toward the requirements for a degree, diploma, certificate, or other formal award.

Data type- Numeric

No value labels exist for this variable.

Number of records in query: 1401

\begin{tabular}{|l|l|l|l|}
\hline Minimum & Maximum & Mean & Standard Deviation \\
\hline 152.00 & $62,525.00$ & $8,065.22$ & $9,934.39$ \\
\hline
\end{tabular}

Variable name: CHG2AY2

Variable label: Published in-state tuition and fees 2003-04 
This variable is described in the definition for variables 1 and 2 in Appendix C. The average instate 2003-04 tuition and fees for public institutions totaled by state were subtracted from the average in-state 2003-04 tuition and fees for private institutions totaled by state. 


\section{Appendix D: Data Sources for NPSAS: 04}

This appendix describes the combinations of major data sources available for the student respondent. Even though available, these sources are not always complete and may not be consistent with each other.

Three major sources:

- CADE (Computer Assisted Data Entry): Data from institutional financial aid and registrar records, entered at the institution by field collectors or institutional personnel or submitted as electronic data files in 2004.

- CATI (Computer Assisted Telephone Interview): Data collected in telephone interviews of the sampled students or self-administered by the students on the web in 2004.

- CPS (Central Processing System): U.S. Department of Education data base of federal financial aid applications for the 2003-04 academic year.

Additional sources used:

- NSLDS (National Student Loan Data System) : U.S. Department of Education data base of federal loans (since 1964) and Pell grants (since 1994)

- IPEDS (Integrated Postsecondary Education System): U.S. Department of Education data base of institutional characteristics The sources are also indicated in the following variables:

INCATI CATI data flag

INCADE CADE data flag

INNSLDS NSLDS federal loan record for 2003-04

INPELL NSLDS Pell grant record for 2003-04

INCPS CPS data for 2003-04 


\section{Appendix E: Variable Definitions}

These variable definitions were obtained from the organizations furnishing the data. The definitions for the IPEDS variables were obtained through DCT provided by NCES. The DCT website is http://nces.ed.gov/ipedspas/. The NPSAS: 04 variable definitions were obtained from the DAS operated by the NCES.

\section{Dissertation variables 1 and 2:}

Variable names: TPBI and TPVI

Variable labels: TPBI: In state tuition and fees per student charged by public institutions

TPVI: In state tuition and fees per student charged by private institutions

Source: IPEDS

IPEDS variable:

Variable name: CHG2AY2

Variable label: Published in-state tuition and fees 2003-04

Description: Price of attendance for full-time, first-time undergraduate students for the full academic year: (Tuition and fees, books and supplies, room and board, and other expenses are those amounts used by an institution's financial aid office for determining eligibility for student financial assistance)

In-state published tuition and required fees for 2003-04

IN-STATE TUITION - The tuition charged by institutions to those students who meet the state's or institution's residency requirements.

TUITION AND REQUIRED FEES - Tuition is the amount of money charged to students for instructional services. Tuition may be charged per term, per course, or per credit. Required fees are fixed sums charged to students for items not covered by tuition and required of such a large proportion of all students that the student who does NOT pay the charge is an exception.

UNDERGRADUATE - A student enrolled in a 4- or 5-year bachelor's degree program, an associate's degree program, or a vocational or technical program below the baccalaureate. FULL-TIME Undergraduate - A student enrolled for 12 or more semester credits, or 12 or more quarter credits, or 24 or more contact hours a week each term

FIRST-TIME FIRST-YEAR STUDENT - A student attending any institution for the first time at the undergraduate level. Includes students enrolled in the fall term who attended college for the first time in the prior summer term. Also includes students who entered with advanced standing (college credits earned before graduation from high school).

FIRST-YEAR STUDENT A student who has completed less than the equivalent of 1 full year of undergraduate work; that is, less than 30 semester hours (in a 120-hour degree program) or less than 900 contact hours.

ACADEMIC YEAR - The period of time generally extending from September to June; usually equated to 2 semesters or trimesters, 3 quarters, or the period covered by a 4-1-4 plan. Also included are "Other Academic Calendar Systems" which is a category used to describe "nontraditional" calendar systems at 4-year and 2-year degree-granting institutions. These can include schools that offer primarily on-line courses or "one course at a time". 
Data type-Numeric

Variable TPBI:

Number of records in query: 519

\begin{tabular}{|l|l|l|l|}
\hline Minimum & Maximum & Mean & Standard Deviation \\
\hline 0.00 & $9,706.00$ & $4,318.51$ & $1,682.77$ \\
\hline
\end{tabular}

Variable TPVI:

Number of records in query: 882

\begin{tabular}{|l|l|l|l|}
\hline Minimum & Maximum & Mean & Standard Deviation \\
\hline 0.00 & $30,330.00$ & $17,005.59$ & $6,341.45$ \\
\hline
\end{tabular}

Dissertation variables 3 and 4:

Variable names: TPBO and TPVO

Variable labels: TPBO: Tuition and Fees per student charged to out-of-state students by public institutions

TPVO: Tuition and Fees per student charged to out-of-state students by private institutions

Source: IPEDS

IPEDS variable:

Variable name: CHG3AY2

Variable label: Published out-of-state tuition and fees 2003-04

Description: Price of attendance for full-time, first-time undergraduate students for the full academic year: (Tuition and fees, books and supplies, room and board, and other expenses are those amounts used by your financial aid office for determining eligibility for student financial assistance).

Out-of-state published tuition and required fees for 2003-04

OUT-OF-STATE TUITION - The tuition charged by institutions to those students who do not meet the institution's or state's residency requirements TUITION AND REQUIRED FEES - Tuition is the amount of money charged to students for instructional services. Tuition may be charged per term, per course, or per credit. Required fees are fixed sum charged to students for items not covered by tuition and required of such a large proportion of all students that the student who does NOT pay the charge is an exception. 
UNDERGRADUATE - A student enrolled in a 4- or 5-year bachelor's degree program, an associate's degree program, or a vocational or technical program below the baccalaureate. FULL-TIME Undergraduate - A student enrolled for 12 or more semester credits, or 12 or more quarter credits, or 24 or more contact hours a week each term

FIRST-TIME FIRST-YEAR STUDENT - A student attending any institution for the first time at the undergraduate level. Includes students enrolled in the fall term who attended college for the first time in the prior summer term. Also includes students who entered with advanced standing (college credits earned before graduation from high school).

FIRST-YEAR STUDENT A student who has completed less than the equivalent of 1 full year of undergraduate work; that is, less than 30 semester hours (in a 120-hour degree program) or less than 900 contact hours.

ACADEMIC YEAR - The period of time generally extending from September to June; usually equated to 2 semesters or trimesters, 3 quarters, or the period covered by a 4-1-4 plan. Also included are "Other Academic Calendar Systems" which is a category used to describe "nontraditional" calendar systems at 4-year and 2-year degree-granting institutions. These can include schools that offer primarily on-line courses or "one course at a time"

Data type-Numeric

Variable TPBO:

Number of records in query: 519

\begin{tabular}{|l|l|l|l|}
\hline Minimum & Maximum & Mean & Standard Deviation \\
\hline 0.00 & $24,778.00$ & $10,912.08$ & $3,786.68$ \\
\hline
\end{tabular}

Variable TPVO:

Number of records in query: 882

\begin{tabular}{|l|l|l|l|}
\hline Minimum & Maximum & Mean & Standard Deviation \\
\hline 0.00 & $30,330.00$ & $17,006.43$ & $6,340.62$ \\
\hline
\end{tabular}

\section{Dissertation variable 5:}

Variable name: DONPB

Variable label: Total amount of revenues collected from private donations per student for public institutions

Source: IPEDS

IPEDS variable:

Variable name: F1B16

Variable label: Gifts, including contributions from affiliated organizations

Description: Gifts, including contributions from affiliated organizations. These are revenues from private donors for which no legal consideration is provided. It includes all gifts or 
contributions to the institution except those classified as additions to permanent endowments or capital grants and gifts.

Data type-Numeric

No value labels exist for this variable.

Number of records in query: 519

\begin{tabular}{|l|l|l|l|}
\hline Minimum & Maximum & Mean & Standard Deviation \\
\hline 0.00 & $170,159,397.00$ & $5,986,429.68$ & $16,749,473.94$ \\
\hline
\end{tabular}

\section{Dissertation variable 6:}

Variable name: DONPV

Variable label: Total amount of revenues collected from private donations per student for private institutions

Source: Philanthropic Research, Inc.

The amount reported on Part 1, line1 of selected private higher education institutions form 990 Return of Organization Exempt from Income Tax returns.

Number of records: 882

Data Type: Numeric

\section{Dissertation variable 7:}

Variable name: APPPB

Variable label: Per student state government appropriations made to public institutions

Source: IPEDS

IPEDS variable:

Variable name: F1B11

Variable label: State appropriations

State appropriations are amounts received by the institution through acts of a state legislative body, except grants and contracts and capital appropriations. Funds reported in this category are for meeting current operating expenses, not for specific projects or programs.

Data type-Numeric

No value labels exist for this variable.

Number of records in query: 519

\begin{tabular}{|l|l|l|l|}
\hline Minimum & Maximum & Mean & Standard Deviation \\
\hline 0.00 & $598,453,000.00$ & $70,390,084.69$ & $88,684,761.44$ \\
\hline
\end{tabular}




\section{Dissertation variable 8:}

Variable name: APPPV

Variable label: Per student state government appropriations made to private institutions

Source: IPEDS

IPEDS variable:

Variable name: F2D03

Variable label: State appropriations

Description: State appropriations includes amounts received from a state government through a direct appropriation of its legislative body, except for state grants and contracts. An example of a state appropriation is an annual state appropriation for operating expenses of the institution

Data type-Numeric

No value labels exist for this variable.

Number of records in query: 882

\begin{tabular}{|l|l|l|l|}
\hline Minimum & Maximum & Mean & Standard Deviation \\
\hline 0.00 & $150,613,355.00$ & $411,155.35$ & $5,409,451.23$ \\
\hline
\end{tabular}

\section{Dissertation variable 9}

Variable name: FRPB

Variable label: Federal operating revenues provided per student to public institutions

IPEDS variables:

Source: IPEDS

IPEDS variables for FRPB:

Variable name: F1B102

Variable label: Federal operating grants and contracts

Variable name: F1B10

Variable label: Federal appropriations

Variable name: F1B13

Variable label: Federal nonoperating grants

Variable name: F2D02

Variable label: Federal appropriations

Variable name: F2D05

Variable label: Federal grants and contracts

Public Institutions usually generate financial statements in accordance standards issued by the Governmental Accounting Standards Board ("GASB"). Some public institutions use standards issued by the Financial Accounting Standards Board ("FASB") to produce their financial 
statements. For the schools issuing GASB statements, the federal revenues per student provided to public institutions were obtained by dividing variables F1B102, F1B10, and F1B13 by the FTE undergraduate enrollment for academic year 2003-04. For the schools using the FASB standards, the federal revenues per student provided to public institutions were obtained by dividing variables F2D02 and F2D05 by the FTE undergraduate enrollment for academic year 2003-04.

F1B02 - Federal operating grants and contracts

Federal operating grants and contracts are revenues from federal government agencies that are for specific research projects or other types of programs and that are classified as operating revenues. Examples are research projects and similar activities for which amounts are received or expenditures are reimbursable under the terms of a grant or contract.

Data type-Numeric

No value labels exist for this variable.

Number of records in query: 519

\begin{tabular}{|l|l|l|l|}
\hline Minimum & Maximum & Mean & Standard Deviation \\
\hline 0.00 & $739,751,042.00$ & $39,152,424.34$ & $83,601,571.79$ \\
\hline
\end{tabular}

F1B10 - Federal appropriations

Federal appropriations are amounts received by the institution through acts of a federal legislative body, except grants and contracts. Funds reported in this category are for meeting current operating expenses, not for specific projects or programs. An example is federal landgrant appropriations. However land grant appropriations may be included in operating revenues if accounted for by the institution as operating revenue.

Data type-Numeric

No value labels exist for this variable.

Number of records in query: 519

\begin{tabular}{|l|l|l|l|}
\hline Minimum & Maximum & Mean & Standard Deviation \\
\hline 0.00 & $26,293,107.00$ & $350,090.06$ & $2,228,215.03$ \\
\hline
\end{tabular}

F1B13 - Federal nonoperating grants

Federal non-operating grants are amounts reported as nonoperating revenues from federal government agencies that are provided on a non-exchange basis. Pell grants are included; however, revenues from the Federal Direct Student Loan Program are not. Capital grants and gifts are also not included. 
Data type-Numeric

No value labels exist for this variable.

Number of records in query: 519

\begin{tabular}{|l|l|l|l|}
\hline Minimum & Maximum & Mean & Standard Deviation \\
\hline 0.00 & $48,836,534.00$ & $2,044,432.85$ & $5,057,922.01$ \\
\hline
\end{tabular}

Variable name: F2D02

Federal appropriations includes amounts received from the federal government through a direct appropriation of Congress, except grants and contracts. An example of a federal appropriation is a federal land grant appropriation.

Data type-Numeric

No value labels exist for this variable.

Number of records in query: 519

\begin{tabular}{|l|l|l|l|}
\hline Minimum & Maximum & Mean & Standard Deviation \\
\hline 0.00 & $18,648,000.00$ & $41,421.49$ & $827,820.46$ \\
\hline
\end{tabular}

F2D05 - Federal grants and contracts

Federal grants and contracts includes all revenues from federal agencies that are for specific undertakings such as research projects, training projects, and similar activities, including contributions from federal agencies. Included in this variable are federal Pell and similar student aid grants when they are treated as student aid expenses when awarded to the student. If federal Pell and similar student aid grants are treated as agency transactions in general purpose financial statements they are excluded from this amount.

Data type-Numeric

No value labels exist for this variable.

Number of records in query: 519

\begin{tabular}{|l|l|l|l|}
\hline Minimum & Maximum & Mean & Standard Deviation \\
\hline 0 & $473,608,705.00$ & $1,843,734.10$ & $25,597,661.11$ \\
\hline
\end{tabular}

\section{Dissertation variable 10}


Variable name: FRPV

Variable label: Federal operating revenues provided per student to private institutions

The federal revenues per student provided to public institutions were obtained by dividing variables F2D02 and F2D05 by the FTE undergraduate enrollment for academic year 2003-04.

IPEDS variables:

Variable name: F2D02

Variable label: Federal appropriations

Variable name: F2D05

Variable label: Federal grants and contracts

Variable name: F2D02

Federal appropriations includes amounts received from the federal government through a direct appropriation of Congress, except grants and contracts. An example of a federal appropriation is a federal land grant appropriation.

Data type-Numeric

No value labels exist for this variable.

Number of records in query: 882

\begin{tabular}{|l|l|l|l|}
\hline Minimum & Maximum & Mean & Standard Deviation \\
\hline 0.00 & $205,081,000.00$ & $427,646.13$ & $7,534,756.30$ \\
\hline
\end{tabular}

F2D05 - Federal grants and contracts

Federal grants and contracts includes all revenues from federal agencies that are for specific undertakings such as research projects, training projects, and similar activities, including contributions from federal agencies. Included are federal Pell and similar student aid grants when they are treated as student aid expenses when awarded to the student. If federal Pell and similar student aid grants are treated as agency transactions in general purpose financial statements they are excluded from this amount.

Data type-Numeric

No value labels exist for this variable.

Number of records in query: 882

\begin{tabular}{|l|l|l|l|}
\hline Minimum & Maximum & Mean & Standard Deviation \\
\hline 0.00 & $914,733,000.00$ & $13,522,449.19$ & $69,786,647.69$ \\
\hline
\end{tabular}




\section{Dissertation variables 11 and 12:}

Variable names: IFPBM and IFPVM

Variable labels: IFPBM: Institutional Merit-based financial aid by public institutions

Source: NPSAS:04

IFPVM: Institutional Merit-based financial aid by private institutions

NPSAS:04 variable:

Variable name: INSMERIT

Variable label: Institutional merit-only grants

Type: Continuous

Description: Total amount of institutional merit-only grants and scholarships received during 2003- 2004 academic year. The total includes all athletic scholarships.

Applies to: All undergraduate respondents.

Statistics

\begin{tabular}{|l|l|l|}
\hline Value & Percentage & Label \\
\hline Continuous & 7.9 & Positive values, see statistics below \\
\hline 0 & 92.1 & Zero \\
\hline
\end{tabular}

\begin{tabular}{|l|l|l|l|}
\hline Minimum & Maximum & Mean & Standard Deviation \\
\hline 100 & 20000 & 4269.28 & 4227.39 \\
\hline
\end{tabular}

Weight used to calculate frequencies: Study Weight (WTA000)

NPSAS Source: NPSAS:04 CADE

Variable IFPBM:

Number of records in query: 43,414

\begin{tabular}{|l|l|}
\hline Mean & Standard Deviation \\
\hline 144.0209 & 1023.9330 \\
\hline
\end{tabular}

Variable IFPVM:

Number of records in query: 10,893

\begin{tabular}{|l|l|}
\hline Mean & Standard Deviation \\
\hline 1531.3640 & 3378.1040 \\
\hline
\end{tabular}

Dissertation variables 13 and 14:

Variable names: IFPBN and IFPVN

Variable labels: IFPBN: Institutional need-based financial aid paid by public institutions

IFPVN: Institutional need-based financial aid paid by private institutions 
Source: NPSAS:04

NPSAS: 04 variables:

Variable name: INSTNEED

Variable label: Institutional need-based grants

Type: Continuous

Description: Total amount of institutional need-based grants received during 2003-2004 academic year. Includes grants based both on need and merit.

Applies to: All undergraduate respondents.

Statistics

\begin{tabular}{|l|l|l|}
\hline Value & Percentage & Label \\
\hline Continuous & 10.3 & Positive values, see statistics below \\
\hline 0 & 89.7 & zero \\
\hline
\end{tabular}

\begin{tabular}{|l|l|l|l|}
\hline Minimum & Maximum & Mean & Standard Deviation \\
\hline 100 & 20000 & 3329.79 & 4412.21 \\
\hline
\end{tabular}

Weight used to calculate frequencies: Study Weight (WTA000)

Source: NPSAS:04 CADE

Variable IFPBN:

Number of records in query: 18,772

\begin{tabular}{|l|l|}
\hline Mean & Standard Deviation \\
\hline 122.1087 & 773.2 \\
\hline
\end{tabular}

Variable IFPVN:

Number of records in query: 10,893

\begin{tabular}{|l|l|}
\hline Mean & Standard Deviation \\
\hline 1685.5600 & 3916.9450 \\
\hline
\end{tabular}

Dissertation variables 15 and 16:

Variable names: SFPBM and SFPVM

Variable labels: SFPBM: State merit-based financial aid paid to students enrolled at public institutions

SFPBM: State merit-based financial aid paid to students enrolled at public institutions

Source: NPSAS:04 
NPSAS: 04 variable:

Variable name: STMERIT

Variable label: State merit-only grants

Type: Continuous

Description: Total amount of state merit-only grants and scholarships received during 2003-2004 academic year. Grants based only on academic merit criteria such as high school grades and admission test scores. Most of the larger state merit-only programs were established in the late 1990's, and the majority of these grants are reported in NPSAS: 2000 were in Georgia and Florida, which have the largest programs. STATNOND includes these academic merit programs as well as categorical grant programs limited to certain categories of students, but not based on need criteria. STATNEED includes grants that are based on both need and academic merit criteria, as well as those based on need only. Students may receive both need-based and nonneed-based grants.

Applies to: All respondents.

Statistics

\begin{tabular}{|l|l|l|}
\hline Value & Percentage & Label \\
\hline Continuous & 3.2 & Positive values, see statistics below \\
\hline 0 & 96.8 & zero \\
\hline
\end{tabular}

\begin{tabular}{|l|l|l|l|}
\hline Minimum & Maximum & Mean & Standard Deviation \\
\hline 111 & 10000 & 1819 & 1360.12 \\
\hline
\end{tabular}

Weight used to calculate frequencies: Study Weight (WTA000)

Source: NPSAS:04 CADE

Variable SFPBM:

Number of records in query: 18,772

\begin{tabular}{|l|l|}
\hline Mean & Standard Deviation \\
\hline 64.5944 & 419.4654 \\
\hline
\end{tabular}

Variable SFPVM:

Number of records in query: 10,893

\begin{tabular}{|l|l|}
\hline Mean & Standard Deviation \\
\hline 58.817 & 418.5122 \\
\hline
\end{tabular}




\section{Dissertation variables 17 and 18:}

Variable names: SFPBN and SFPVN

Variable labels: SFPBN: State need-based financial aid paid to students enrolled at public institutions

SFPBN: State need-based financial aid paid to students enrolled at private

Source: NPSAS:04 institutions

NPSAS: 04 variable:

Variable name: STATNEED

Variable label: State-need-based grants

Type: Continuous

Description: Total amount of state need-based grants received during 2003-2004 academic year. Includes grants based only on need or on both need and merit.

Applies to: All respondents.

Statistics

\begin{tabular}{|l|l|l|}
\hline Value & Percentage & Label \\
\hline Continuous & 11.5 & Positive values \\
\hline 0 & 88.5 & zero \\
\hline
\end{tabular}

\begin{tabular}{|l|l|l|l|}
\hline Minimum & Maximum & Mean & Standard Deviation \\
\hline 94 & 10000 & 1942.90 & 1705.25 \\
\hline
\end{tabular}

Weight used to calculate frequencies: Study Weight (WTA000)

Source: NPSAS:04 CADE

Variable SFPBN:

Number of records in query: 18,772

\begin{tabular}{|l|l|}
\hline Mean & Standard Deviation \\
\hline 172.3011 & 674.4069 \\
\hline
\end{tabular}

Variable SFPVN:

Number of records in query: 10,893

\begin{tabular}{|l|l|}
\hline Mean & Standard Deviation \\
\hline 548.6213 & 1421.8800 \\
\hline
\end{tabular}

Dissertation variables 19 and 20:

Variable name: FFPB and FFPV 
Variable labels: FFPB: Federal grant aid per student enrolled at public institutions

FFPV: Federal grant aid per student enrolled at private institutions

Source: NPSAS:04

NPSAS: 04 variable:

Variable name: TFEDGRT

Variable label: Total federal grants

Type: Continuous

Description: Total amount of federal grants received during 2003-2004 academic year. Primarily Pell grants (PELLAMT) and Supplemental Educational Opportunity Grants (SEOGAMT); but also includes amounts from several small programs and any other federal graduate fellowships or traineeships received during 2003-2004 academic year (OTHFDGRT). This variable does not include federal veteran's benefits or military aid (VADODAMT).

Applies to: All respondents.

Statistics

\begin{tabular}{|l|l|l|}
\hline Value & Percentage & Label \\
\hline Continuous & 27.6 & Positive values, see statistics below \\
\hline 0 & 72.4 & Zero \\
\hline
\end{tabular}

\begin{tabular}{|l|l|l|l|}
\hline Minimum & Maximum & Mean & Standard Deviation \\
\hline 100 & 21993 & 2608.59 & 1458.92 \\
\hline
\end{tabular}

Variable FFPB:

Number of records in query: 18,772

\begin{tabular}{|l|l|}
\hline Mean & Standard Deviation \\
\hline 618.3502 & 1296.2110 \\
\hline
\end{tabular}

Variable FFPV:

Number of records in query: 10,893

\begin{tabular}{|l|l|}
\hline Mean & Standard Deviation \\
\hline 864.2303 & 1609.7450 \\
\hline
\end{tabular}

Weight used to calculate frequencies: Study Weight (WTA000)

Source: Derived

Dissertation variables 21, 22, 23 and 24:

Variable names: TGVTBPBI, TGVTBPVI, TGVTBPBO, and TGVTBPVO

Variable labels: TGVTBPBI: Tuition and fees minus all grants, veteran, and tax benefits for instate students enrolled at public institutions TGVTBPVI: Tuition and fees minus all grants, veteran, and tax benefits for in-state students enrolled at private institutions 
TGVTBPBO: Tuition and fees minus all grants, veteran, and tax benefits for out-of-state students enrolled at public institutions

TGVTBPVO: Tuition and fees minus all grants, veteran, and tax benefits for out-of-state students enrolled at private institutions

NPSAS:04 Variable:

Variable Name: NETCST38

Variable Label: Tuition and fees minus federal grants, veteran, and tax benefits

Type: Continuous

Description: Tuition and fees minus federal grants, veteran's benefits or Department of Defense aid, and federal education tax benefits for the 2003-2004 academic year. Equal to tuition and fees (TUITION2) minus federal grants, veteran's benefits, and tax benefits (TFEDGRT3). Grant aid helps cover the entire student budget, not just tuition, so it may be greater than tuition alone. This variable was set to zero if TOTGRT2 was greater than TUITION2. Values less than $\$ 10$ (19 ) were set to a minimum of $\$ 10$. Students who attended more than one institution (STUDMULT $>1$ ) were skipped. Derived from: TUITION2 TFEDGRT VADODAMT TXTOTBEN Applies to: Respondents who attended one institution (STUDMULT=1).

\begin{tabular}{|l|l|l|}
\hline Value & Percentage & Label \\
\hline Continuous & 77.7 & Positive values, see statistics below \\
\hline 0 & 14.8 & Zero \\
\hline-9 & 7.5 & Missing \\
\hline
\end{tabular}

\begin{tabular}{|l|l|l|l|}
\hline Minimum & Maximum & Average & Standard Deviation \\
\hline 1 & 39583 & 4302.35 & 6053.94 \\
\hline
\end{tabular}

\section{Variable TGVTBPBI:}

Number of records in query: 18,772 MEAN

$1026.623 \quad 1606.08$

Number of records in query: 10,893

Variable: TGVTBPVI

$$
\begin{array}{ll}
\text { MEAN } & \text { STD } \\
6192.99 & 6610.808
\end{array}
$$

Variable: TGVTBPBO 
Number of records in query: 18,772

MEAN

STD

$5191.594 \quad 5879.311$

Variable: TGVTBPVO

Number of records in query: 10,893

$\begin{array}{cc}\text { MEAN } & \text { STD } \\ 11015.06 & 9561.972\end{array}$

Weight used to calculate frequencies: Study Weight (WTA000)

Source: Derived

\section{Dissertation variable 25:}

Variable name: SE

Variable Label: Selectivity of the institution

Source: IPEDS

IPEDS variables:

Variable name: APPLCN

Variable label: Applicants total

Variable name: ADMSSN

Variable label: Admissions total

Selectivity was determined by dividing the total admissions by the total applicants.

\section{Variable: APPLCN}

APPLICANT - An individual who has fulfilled the institution's requirements to be considered for admission (including payment or waiving of the application fee, if any) and who has been notified of one of the following actions: admission, nonadmission, placement on waiting list, or application withdrawn (by applicant or institution).

FIRST-TIME STUDENT (UNDERGRADUATE) - A student attending any institution for the first time at the undergraduate level. Includes students enrolled in academic or occupational programs. Also includes students enrolled in the fall term who attended college for the first time in the prior summer term, and students who entered with advanced standing (college credits earned before graduation from high school).

DEGREE/CERTIFICATE-SEEKING STUDENTS - Students enrolled in courses for credit who are recognized by the institution as seeking a degree or formal award. At the undergraduate level, this is intended to include students enrolled in vocational or occupational programs. 
EARLY DECISION - A plan that allows students to apply and be notified of an admission decision (and financial aid offer, if applicable) well in advance of the regular notification date. Applicants agree to accept an offer of admission and, if admitted, to withdraw their applications from other colleges. There are three possible decision applications: admitted, denied, or not admitted but forwarded for consideration with the regular applicant pool, without prejudice.

EARLY ACTION - An admission plan that allows students to apply and be notified of an admission decision well in advance of the regular notification dates. If admitted, the candidate is not committed to enroll (unlike early decision). Students may reply to the offer under the college's regular reply policy.

Data type-Numeric

Number of records in query: 1401

\begin{tabular}{|l|l|l|l|}
\hline Minimum & Maximum & Mean & Standard Deviation \\
\hline 0.00 & $44,981.00$ & $3,730.11$ & $5,286.82$ \\
\hline
\end{tabular}

Public institutions:

Number of records in query: 519

\begin{tabular}{|l|l|l|l|}
\hline Minimum & Maximum & Mean & Standard Deviation \\
\hline 0 & 44981 & 5862.092 & 6717.458 \\
\hline
\end{tabular}

Private institutions:

Number of records in query: 882

\begin{tabular}{|l|l|l|l|}
\hline Minimum & Maximum & Mean & Standard Deviation \\
\hline 0 & 34457 & 2475.578231 & 3692.045515 \\
\hline
\end{tabular}

Variable: ADMSSN

The number of first-time, degree/certificate-seeking undergraduate students who applied, were admitted, and enrolled (full or part time) at an institution for the most recent fall period available. Included were early decision, early action, and students who began studies during the summer prior to that fall. This was applicable to institutions that have no open admission policy for entering first-time undergraduate students

ADMISSIONS - Applicants that have been granted an official offer to enroll in a college or university. 
FIRST-TIME STUDENT (UNDERGRADUATE) - A student attending any institution for the first time at the undergraduate level. Includes students enrolled in academic or occupational programs. Also includes students enrolled in the fall term who attended college for the first time in the prior summer term, and students who entered with advanced standing (college credits earned before graduation from high school).

DEGREE/CERTIFICATE-SEEKING STUDENTS - Students enrolled in courses for credit who are recognized by the institution as seeking a degree or formal award. At the undergraduate level, this is intended to include students enrolled in vocational or occupational programs.

EARLY DECISION - A plan that allows students to apply and be notified of an admission decision (and financial aid offer, if applicable) well in advance of the regular notification date. Applicants agree to accept an offer of admission and, if admitted, to withdraw their applications from other colleges. There are three possible decision applications: admitted, denied, or not admitted but forwarded for consideration with the regular applicant pool, without prejudice.

EARLY ACTION - An admission plan that allows students to apply and be notified of an admission decision well in advance of the regular notification dates. If admitted, the candidate is not committed to enroll (unlike early decision). Students may reply to the offer under the college's regular reply policy.

Data type-Numeric

Number of records in query: 1401

\begin{tabular}{|l|l|l|l|}
\hline Minimum & Maximum & Mean & Standard Deviation \\
\hline 0.00 & $22,297.00$ & $2,263.41$ & $2,984.49$ \\
\hline
\end{tabular}

Public institutions:

Number of records in query: 519

\begin{tabular}{|l|l|l|l|}
\hline Minimum & Maximum & Mean & Standard Deviation \\
\hline 0 & 22297 & 3778.774566 & 3988.139461 \\
\hline
\end{tabular}

Private institutions:

Number of records in query: 882

\begin{tabular}{|l|l|l|l|}
\hline Minimum & Maximum & Mean & Standard Deviation \\
\hline 0 & 15191 & 1371.716553 & 1629.063717 \\
\hline
\end{tabular}


Selectivity percent:

Public institutions:

Number of records in query: 519

\begin{tabular}{|l|l|l|l|}
\hline Minimum & Maximum & Mean & Standard Deviation \\
\hline $14.77 \%$ & $100 \%$ & $70.14 \%$ & $17.22 \%$ \\
\hline
\end{tabular}

Private institutions:

Number of records in query: 882

\begin{tabular}{|l|l|l|l|}
\hline Minimum & Maximum & Mean & Standard Deviation \\
\hline $0 \%$ & $100 \%$ & $67.09 \%$ & $18.39 \%$ \\
\hline
\end{tabular}

\section{Dissertation variable 26:}

Variable name: CC

Variable label: Carnegie Foundation classification

Source: IPEDS

IPEDS variable:

Variable name: CARNEGIE

Variable label: Carnegie Classification Code

Description: The 2000 Carnegie Classification includes all colleges and universities in the United States that are degree-granting and accredited by an agency recognized by the U.S. Secretary of Education. The 2000 edition classifies institutions based on their degree-granting activities from 1995-96 through 1997-98.

15 Doctoral/Research Universities--Extensive: These institutions typically offer a wide range of baccalaureate programs, and they are committed to graduate education through the doctorate. They award 50 or more doctoral degrees per year across at least 15 disciplines/2

16 Doctoral/Research Universities--Intensive: These institutions typically offer a wide range of baccalaureate programs, and they are committed to graduate education through the doctorate. They award at least ten doctoral degrees/ 1 per year across three or more disciplines, 2 or at least 20 doctoral degrees per year overall.

21 Master's Colleges and Universities I: These institutions typically offer a wide range of baccalaureate programs, and they are committed to graduate education through the master's degree. They award 40 or more master's degrees per year across three or more disciplines.

22 Master's (Comprehensive) Colleges and Universities II: These institutions typically offer a wide range of baccalaureate programs, and they are committed to graduate education through the 
master's degree. They award 20 or more master's degrees per year.

31 Baccalaureate Colleges--Liberal Arts: These institutions are primarily undergraduate colleges with major emphasis on baccalaureate programs. They award at least half of their baccalaureate degrees in liberal arts fields./3

32 Baccalaureate Colleges--General: These institutions are primarily undergraduate colleges with major emphasis on baccalaureate programs. They award less than half of their baccalaureate degrees in liberal arts fields./3

33 Baccalaureate/Associate's Colleges:

These institutions are undergraduate colleges where the majority of conferrals are at the subbaccalaureate level (associate's degrees and certificates), but bachelor's degrees account for at least ten percent of undergraduate awards.

40 Associate's Colleges: These institutions offer associate's degree and certificate programs but, with few exceptions, award no baccalaureate degrees./4

Specialized Institutions - These institutions offer degrees ranging from the bachelor's to the doctorate, and typically award a majority of degrees in a single field. The list includes only institutions that are listed as separate campuses in the Higher Education Directory. Specialized institutions include:

51 Theological seminaries and other specialized faith-related institutions: These institutions primarily offer religious instruction or train members of the clergy.

52 Medical schools and medical centers: These institutions award most of their professional degrees in medicine. In some instances, they include other health professions programs, such as dentistry, pharmacy, or nursing.

53 Other separate health profession schools: These institutions award most of their degrees in such fields as chiropractic, nursing, pharmacy, or podiatry.

54 Schools of engineering and technology: These institutions award most of their bachelor's or graduate degrees in technical fields of study.

55 Schools of business and management: These institutions award most of their bachelor's or graduate degrees in business or business-related programs.

56 Schools of art, music, and design: These institutions award most of their bachelor's or graduate degrees in art, music, design, architecture, or some combination of such fields.

57 Schools of law: These institutions award most of their degrees in law.

58 Teachers colleges: These institutions award most of their bachelor's or graduate degrees in education or education-related fields. 
59 Other specialized institutions: Institutions in this category include graduate centers, maritime academies, military institutes, and institutions that do not fit any other classification category.

60 Tribal Colleges and Universities: These colleges are, with few exceptions, tribally controlled and located on reservations. They are all members of the American Indian Higher Education Consortium.

\section{NOTES ON DEFINITIONS}

1. Doctoral degrees are as defined in the Integrated Postsecondary Education Data System (IPEDS) of the U.S. Department of Education's National Center for Education Statistics (NCES). This includes the Ph.D. in any field as well as other doctoral-level degrees such as the Doctor of Education, Doctor of Juridical Science, and Doctor of Public Health. It excludes doctoral-level degrees defined as first-professional degrees in IPEDS. For more information, see http://nces.ed. gov/ipeds.

2. Distinct disciplines are determined by the 4-digit series of the Classification of Instructional Programs published by NCES. For more information, see http://nces.ed.gov/pubsearch /pubsinfo .asp?pubid=91396.

3. Liberal arts fields include the following fields (as listed in the Classification of Instructional Programs): English language and literature/letters; foreign languages and literatures; biological sciences/life sciences; mathematics; philosophy and religion; physical sciences; psychology; social sciences and history; visual and performing arts; area, ethnic, and cultural studies; liberal arts and sciences, general studies, and humanities; and multi/interdisciplinary studies.

4. This group includes community, junior, and technical colleges.

NPSAS: 04 source: Carnegie Foundation

Data type-Numeric

\begin{tabular}{|l|l|l|l|}
\hline Value Label & Code Value & Frequency & Percentage \\
\hline Doctoral/Research Universities--Extensive & 15 & 151 & $10.78 \%$ \\
\hline Doctoral/Research Universities--Intensive & 16 & 104 & $7.42 \%$ \\
\hline Masters Colleges and Universities I & 21 & 482 & $34.40 \%$ \\
\hline Masters Colleges and Universities II & 22 & 104 & $7.42 \%$ \\
\hline Baccalaureate Colleges--Liberal Arts & 31 & 218 & $15.56 \%$ \\
\hline Baccalaureate Colleges--General & 32 & 300 & $21.41 \%$ \\
\hline Baccalaureate/Associates Colleges & 33 & 42 & $3.00 \%$ \\
\hline Totals & & 1,401 & $100 \%$ \\
\hline
\end{tabular}

Public Institutions:

Data type-Numeric

\begin{tabular}{|l|l|l|l|}
\hline Value Label & Code Value & Frequency & Percentage \\
\hline Doctoral/Research Universities--Extensive & 15 & 102 & $11.56 \%$ \\
\hline
\end{tabular}




\begin{tabular}{|l|l|l|l|}
\hline Doctoral/Research Universities--Intensive & 16 & 63 & $7.14 \%$ \\
\hline Masters Colleges and Universities I & 21 & 247 & $28.00 \%$ \\
\hline Masters Colleges and Universities II & 22 & 24 & $2.72 \%$ \\
\hline Baccalaureate Colleges--Liberal Arts & 31 & 24 & $2.72 \%$ \\
\hline Baccalaureate Colleges--General & 32 & 45 & $5.10 \%$ \\
\hline Baccalaureate/Associates Colleges & 33 & 14 & $1.59 \%$ \\
\hline Totals & & 519 & $100 \%$ \\
\hline
\end{tabular}

Private Institutions:

Data type-Numeric

\begin{tabular}{|l|l|l|l|}
\hline Value Label & Code Value & Frequency & Percentage \\
\hline Doctoral/Research Universities--Extensive & 15 & 49 & $5.56 \%$ \\
\hline Doctoral/Research Universities--Intensive & 16 & 41 & $4.65 \%$ \\
\hline Masters Colleges and Universities I & 21 & 235 & $26.64 \%$ \\
\hline Masters Colleges and Universities II & 22 & 80 & $9.07 \%$ \\
\hline Baccalaureate Colleges--Liberal Arts & 31 & 194 & $22.00 \%$ \\
\hline Baccalaureate Colleges-General & 32 & 255 & $28.91 \%$ \\
\hline Baccalaureate/Associates Colleges & 33 & 28 & $3.17 \%$ \\
\hline Totals & & 519 & $100 \%$ \\
\hline
\end{tabular}

Numeric Value Assigned to classification

\begin{tabular}{|l|l|}
\hline Value Label & Numeric Value \\
\hline Doctoral/Research Universities--Extensive & 1 \\
\hline Doctoral/Research Universities--Intensive & 2 \\
\hline Masters Colleges and Universities I & 3 \\
\hline Masters Colleges and Universities II & 4 \\
\hline Baccalaureate Colleges--Liberal Arts & 5 \\
\hline Baccalaureate Colleges-General & 6 \\
\hline Baccalaureate/Associates Colleges & 7 \\
\hline
\end{tabular}

\section{Dissertation variable 27:}

Variable name: CR

Variable label: Per Capita tax revenue for the state in which a school is operated.

Source: U.S. Census Bureau

Description: The per-capita tax revenue of the states. An average for each state was calculated from 2003 and 2004 data.

Data Type: Numeric

Number of records: 50

\begin{tabular}{|l|l|l|l|}
\hline Minimum & Maximum & Mean & Standard Deviation \\
\hline $3,673.58$ & $12,069.35$ & $5,192.48$ & 1386.53 \\
\hline
\end{tabular}




\section{Dissertation variable 28:}

Variable name: DEM

Variable label: Political power in the legislature

Source: National Conference of State Legislatures

Description: The percentage of democratic members in the legislative bodies of the state.

The composition of the state legislative bodies resulting from the 2002 elections was used to calculate these data. The party affiliations of the candidates for the Nebraska Legislature are not listed on ballots. As a result, the legislature is a nonpartisan body and no data are available for Nebraska.

Data Type: Numeric

Number of Records: 49

\begin{tabular}{|l|l|l|l|}
\hline Minimum & Maximum & Mean & Standard Deviation \\
\hline 21.90 & 85.00 & 49.21 & 0.145956185 \\
\hline
\end{tabular}

\section{Dissertation variable 29:}

Variable name: DEPRPB

Variable label: Public institution depreciation expense per student

Source: IPEDS

IPEDS variables:

Variable name: F1C194

Variable label: Total expenses deductions - Depreciation

Variable name: F2E135

Variable label: Total expenses-Depreciation

Total expenses-Depreciation

For public institutions producing financial statements in accordance with GASB standards, the depreciation expense per student was obtained by dividing variable F1C193 by the student FTE. The depreciation expense per student was obtained for institutions producing financial statements in accordance with FASB standards by dividing the F2E135 by the student FTE.

F1C194 - Total expenses deductions - Depreciation

Total expenses and deductions - depreciation is the sum of operating and non-operating depreciation expenses.

Data type-Numeric

No value labels exist for this variable.

Number of records in query: 519 


\begin{tabular}{|l|l|l|l|}
\hline Minimum & Maximum & Mean & Standard Deviation \\
\hline 0.00 & $230,906,000.00$ & $13,783,747.94$ & $25,551,828.33$ \\
\hline
\end{tabular}

F2E135 - Total expenses-Depreciation

The depreciation expense per student was obtained for institutions producing financial statements in accordance with FASB standards by dividing the F2E135 by the student FTE.

Data type-Numeric

No value labels exist for this variable.

Number of records in query: 519

\begin{tabular}{|l|l|l|l|}
\hline Minimum & Maximum & Mean & Standard Deviation \\
\hline 0.00 & $131,379,000.00$ & $639,784.20$ & $7,618,452.08$ \\
\hline
\end{tabular}

\section{Dissertation variable 30:}

Variable name: DEPRPV

Variable label: Private institution depreciation expense per student

Source: IPEDS

IPEDS variable:

Variable name: F2E135

Variable label: Total expenses-Depreciation

F2E135 - Total expenses-Depreciation

Total expenses-Depreciation

Data type-Numeric

No value labels exist for this variable.

Number of records in query: 882

\begin{tabular}{|l|l|l|l|}
\hline Minimum & Maximum & Mean & Standard Deviation \\
\hline 0.00 & $197,134,000.00$ & $6,223,523.18$ & $18,231,054.13$ \\
\hline
\end{tabular}

\section{Dissertation variable 31:}

Variable name: PUB

Variable label: Institutional Control

Source: IPEDS

IPEDS variable: 
Variable name: CONTROL

Variable label: Control of institution

Description: A classification of whether an institution is operated by publicly elected or appointed officials or by privately elected or appointed officials and derives its major source of funds from private sources.

PUBLIC INSTITUITON - An educational institution whose programs and activities are operated by publicly elected or appointed school officials and which is supported primarily by public funds.

PRIVATE NOT-FOR-PROFIT INSTITUTION - A private institution in which the individual(s) or agency in control receives no compensation, other than wages, rent, or other expenses for the assumption of risk. These include both independent not-for-profit schools and those affiliated with a religious organization.

PRIVATE FOR-PROFIT INSTITUION - A private institution in which the individual(s) or agency in control receives compensation other than wages, rent, or other expenses for the assumption of risk.

Data type-Numeric

\begin{tabular}{|l|l|l|l|}
\hline Value Label & Code Value & Frequency & Percentage \\
\hline Public & 1 & 519 & $37.04 \%$ \\
\hline Private not-for-profit & 2 & 882 & $62.96 \%$ \\
\hline Totals & & 1,401 & $100 \%$ \\
\hline
\end{tabular}

\section{Dissertation variable 32:}

Variable name: PROGI

Variable label: Institution's enrollment by program from IPEDS data

Source: IPEDS

IPEDS variables:

Variable name: MAJORNUM

Variable Label: First or Second Major

Variable name: CIPCODE

Variable label: CIP Code - 2000 Classification

Variable name: AWLEVEL

Variable label: Award Level code

Variable name: CRACE24

Variable label: Grand total

MAJORNUM: First Majors were selected. 


\section{CIPCODE :}

Description: CIP Code - 2000 Classification. Classification of instrucional Program (CIP) code. A six-digit code in the form Xx.xxxx that identifies instructional program specialties within educational institutions.

Data type: Alpha

\begin{tabular}{|lrrr|}
\hline Value Label & $\begin{array}{c}\text { Code } \\
\text { Value }\end{array}$ & Frequency & Percentage \\
Agriculture, agriculture operations, and related & 1 & 49 & $0.33 \%$ \\
sciences. & & & \\
Natural resources and conservation. & 3 & 323 & $2.19 \%$ \\
Architecture and related services. & 4 & 62 & $0.42 \%$ \\
Area, ethnic, cultural, and gender studies. & 5 & 274 & $1.86 \%$ \\
Communication, journalism, and related programs. & 9 & 606 & $4.12 \%$ \\
Communications technologies/technicians and & 10 & 47 & $0.32 \%$ \\
support services. & & & \\
Computer and information sciences and support & 11 & 698 & $4.74 \%$ \\
services. & & & \\
Personal and culinary services. & 12 & 21 & $0.14 \%$ \\
Education. & 13 & 772 & $5.24 \%$ \\
Engineering. & 14 & 208 & $1.41 \%$ \\
Engineering technologies/technicians. & 15 & 92 & $0.62 \%$ \\
Foreign languages, literatures, and linguistics. & 16 & 550 & $3.74 \%$ \\
Family and consumer sciences/human sciences. & 19 & 140 & $0.95 \%$ \\
Legal professions and studies. & 22 & 201 & $1.37 \%$ \\
English language and literature/letters. & 23 & 798 & $5.42 \%$ \\
Liberal arts and sciences, general studies and & 24 & 581 & $3.95 \%$ \\
humanities. & & & \\
Library science. & 25 & 19 & $0.13 \%$ \\
Biological and biomedical sciences. & 26 & 786 & $5.34 \%$ \\
Mathematics and statistics. & 27 & 720 & $4.89 \%$ \\
Multi/interdisciplinary studies. & 30 & 523 & $3.55 \%$ \\
Parks, recreation, leisure, and fitness studies. & 31 & 382 & $2.59 \%$ \\
Philosophy and religious studies. & 38 & 626 & $4.25 \%$ \\
Theology and religious vocations. & 39 & 329 & $2.23 \%$ \\
Physical sciences. & 40 & 637 & $4.33 \%$ \\
Science technologies/technicians. & 41 & 13 & $0.09 \%$ \\
Psychology. & 42 & 806 & $5.47 \%$ \\
Security and protective services. & 43 & 293 & $1.99 \%$ \\
Public administration and social service professions. & 44 & 445 & $3.02 \%$ \\
Social sciences. & 45 & 759 & $5.16 \%$ \\
Construction trades. & 46 & 5 & $0.03 \%$ \\
Mechanic and repair technologies/technicians. & 47 & 13 & $0.09 \%$ \\
Precision production. & 48 & 5 & $0.03 \%$
\end{tabular}


Transportation and materials moving.

Visual and performing arts.

49

Health professions and related clinical sciences.

\section{1}

Business, management, marketing, and related

52

support services.

History

54

Totals

54

\begin{tabular}{|rrr|}
\hline 9 & 38 & $0.26 \%$ \\
\hline 1 & 765 & $5.20 \%$ \\
2 & 610 & $4.14 \%$ \\
& 804 & $5.46 \%$ \\
& & \\
\hline & 1422 & $4.90 \%$ \\
\hline
\end{tabular}

\section{AWLEVEL:}

Variable Description: Award Level Code

Data type: Numeric

No value labels exist for this variable.

Degrees/Certificates Total

\section{CRACE24:}

Variable Description: Grand total. Awards/degrees conferred between July 1, 2003 and June 30, 2004 to all recipients, across all race/ethnicities and both genders

Data type: Numeric

No value labels exist for this variable.

Public Institutions:

Number of records in query: 10,522

\begin{tabular}{|l|c|l|r|}
\hline Minimum & Maximum & Mean & Standard Deviation \\
\hline 0.00 & $2,634.00$ & 121.22 & 212.3 \\
\hline
\end{tabular}

Private Institutions:

Number of records in query: 14,722

\begin{tabular}{|l|c|l|r|}
\hline Minimum & Maximum & Mean & Standard Deviation \\
\hline 0.00 & $7,646.00$ & 48.72 & 145.91 \\
\hline
\end{tabular}

The SAS code from variable 31 was used to assign each CIPCODE to the 12 higher level groups defined in variable 31 . Percentages of the total degrees for each institution were calculated for each category.

\section{Dissertation variable 33:}


Variable name: PROGN

Variable label: Institution's enrollments by program obtained from NPSAS: 04 Data

Source: NPSAS:04

NPSAS:04 variable:

Variable name: MAJORS12

Variable label: Field of study: undergraduate (12 cat)

Type: Categorical

Description: Student's undergraduate major or field of study during 2003-2004

academic year. This variable is the condensed version of MAJORS.

Categories

Undeclared or not in a degree program

Humanities

Social/behavioral sciences

Life sciences

Physical sciences

Math

Computer/information science

Engineering

Education

Business/management

Health

Vocational/technical

Other technical/professional

SAS Code:

IF MAJORS $=0$ THEN MAJORS $12=0$;

ELSE IF MAJORS IN $(4,12,15,16,23,24,34)$ THEN MAJORS12=1;

ELSE IF MAJORS IN $(27,37,40,42,43,44,45)$ THEN MAJORS12=2;

ELSE IF MAJORS IN $(2,18,21,22,38,41)$ THEN MAJORS12=3;

ELSE IF MAJORS $=25$ THEN MAJORS $12=4$;

ELSE IF MAJORS $=19$ THEN MAJORS $12=5$;

ELSE IF MAJORS $=7$ THEN MAJORS $12=6$;

ELSE IF MAJORS IN $(10,11)$ THEN MAJORS12=7;

ELSE IF MAJORS $=9$ THEN MAJORS $12=8$;

ELSE IF MAJORS $=36$ THEN MAJORS12 $=9$;

ELSE IF MAJORS IN $(35,46)$ THEN MAJORS $12=10$;

ELSE IF MAJORS IN $(26,30,31,32,33,28)$ THEN MAJORS12=11;

ELSE MAJORS12 $=12$;

Derived from: MAJORS

Revised: 6/27/2005

Applies to: All undergraduate respondents.

\begin{tabular}{|l|l|l|}
\hline Value & \multicolumn{1}{c|}{ Percentage } & \multicolumn{1}{c|}{ Label } \\
\hline 0 & 21.3 & $\begin{array}{l}\text { Undeclared or not in a degree } \\
\text { program }\end{array}$ \\
\hline 1 & 10.3 & Humanities \\
\hline 2 & 7.0 & Social/behavioral sciences \\
\hline
\end{tabular}




\begin{tabular}{|l|l|l|}
\hline 3 & 3.9 & Life sciences \\
\hline 4 & 0.6 & Physical sciences \\
\hline 5 & 0.5 & Math \\
\hline 6 & 4.9 & Computer/information science \\
\hline 7 & 4.2 & Engineering \\
\hline 8 & 6.7 & Education \\
\hline 9 & 15.6 & Business/management \\
\hline 10 & 12.9 & Health \\
\hline 11 & 2.4 & Vocational/technical \\
\hline 12 & 9.7 & Other technical/professional \\
\hline
\end{tabular}

Weight used to calculate frequencies: Study Weight (WTA000)

Source: Derived

\section{Dissertation variable 34:}

Variable name: R

Variable label: Current enrollment as a percentage of the sum of the high-school graduates in the past four years

Source: Public Elementary and Secondary Students, Staff, Schools, and School Districts: School year 2003-04, published by NCES.

Description: Total head count enrollments by each state and the District of Columbia divided by the number of high school students receiving diplomas or passing the General Education Development (GED) tests for each state and the District of Columbia.

Total head count enrollments by each state:

Data type: Numeric

Number of records: 51

\begin{tabular}{|l|l|l|l|}
\hline Minimum & Maximum & Mean & Standard Deviation \\
\hline 11318 & 1292047 & 205187 & 228934 \\
\hline
\end{tabular}

Enrollments as a percentage of high school graduates:

Public institutions:

Data type: Numeric

Number of records: 519 


\begin{tabular}{|l|l|l|l|}
\hline Minimum & Maximum & Mean & Standard Deviation \\
\hline $0.15 \%$ & $98.47 \%$ & $8.38 \%$ & $11.71 \%$ \\
\hline
\end{tabular}

Private Institutions

Data type: Numeric

Number of records: 882

\begin{tabular}{|l|l|l|l|}
\hline Minimum & Maximum & Mean & Standard Deviation \\
\hline $0.07 \%$ & $253.72 \%$ & $2.57 \%$ & $11.31 \%$ \\
\hline
\end{tabular}

\section{Dissertation variable 35:}

Variable name: $2 \mathrm{Y}$

Variable label: Percentage of student enrolled in two-year colleges.

Source: IPEDS

IPEDS variable:

Variable name: FTE12MN

Variable label: 12-month full-time equivalent enrollment: Academic year 2003-04

12-month full-time equivalent enrollment: Academic year 2003-04.

The full-time-equivalent (FTE) enrollment used in this report is the sum of the institutions' FTE undergraduate enrollment and FTE graduate enrollment (as calculated from or reported on the 2004 Enrollment component) plus the estimated FTE of first-professional students.

Undergraduate and graduate FTE are estimated using 12-month instructional activity (credit and/or contact hours). First-professional FTE is estimated by calculating the ratio of full-time to part-time first-professional students from the fall counts (part A) and applying this ratio to the 12 -month unduplicated headcount of first-professional students. The estimated number of fulltime students is added to one-third of the estimated number of part-time students.

The calculation of FTE undergraduate and graduates is as follows:

Quarter calendar system

Enrollment level (One FTE over 12-month period)

Undergraduate 45 credit hours, 900 contact hours

Graduate 36 credit hours

Semester/trimester/4-1-4 plan/other calendar system

Enrollment level (one FTE over 12-month period)

Undergraduate 30 credit hours 900 contact hours

Graduate 24 credit hours

For institutions with continuous enrollment programs, FTE is determined by dividing the number of contact hours attempted by 900 . 
Data type-N

No value labels exist for this variable.

Number of records in query: 1143

\begin{tabular}{|l|l|l|l|}
\hline Minimum & Maximum & Mean & Standard Deviation \\
\hline 0.00 & $38,499.00$ & $3,655.36$ & $4,032.05$ \\
\hline
\end{tabular}

\section{Dissertation variable 36:}

Variable name: STAT62

Variable label: Institution's status as an 1862 Land grant institution

Source: National Association of State Universities and Land Grant Colleges

Description: The Status of an institution as an 1862 land grant institution.

Type: Numeric

Number of records: 58

Dissertation variable 37:

Variable name: STAT90

Variable label: Institution's status as an 1890 Land grant institution

Source: National Association of State Universities and Land Grant Colleges

Description: The Status of an institution as an 1890 land grant institution.

Type: Numeric

Number of records: 17

\section{Dissertation variable 38:}

Variable name: $\mathrm{T}$

Variable label: Tuition and fee charges per student

Source: NPSAS:04

NPSAS:04 variable:

Variable name: TUITION2

Variable label: Tuition and fees (NPSAS)

Type: Continuous

Description: Tuition and fees at the sampled NPSAS institution for students who attended only one institution (STUDMULT=1) during 2003-2004 academic year. Students who attended more than one institution (STUDMULT $>1$ ) were skipped, because tuition at institution other than NPSAS is not known. The tuition reported by institutions in CADE was the primary source, edited and adjusted for attendance status if necessary. If tuition was not reported in CADE, tuition was taken from the most recent IPEDS report and adjusted for attendance status. Applies to: Respondents who attended one institution STUDMULT=1). 
Statistics

\begin{tabular}{|l|l|l|}
\hline Value & Percentage & Label \\
\hline Continuous & 92.5 & Positive values, see statistics below \\
\hline-3 & 7.5 & Skipped \\
\hline
\end{tabular}

\begin{tabular}{|l|l|l|l|}
\hline Minimum & Maximum & Mean & Standard Deviation \\
\hline 10 & 39754 & 4526.33 & 6021.17 \\
\hline
\end{tabular}

Weight used to calculate frequencies: Study Weight (WTA000)

Source: NPSAS:04 CADE, IPEDS-IC, Logical imputation

Public Institutions:

Number of records: 18,772

\begin{tabular}{|l|l|}
\hline Mean & Standard Deviation \\
\hline 2409.021 & 2773.5070 \\
\hline
\end{tabular}

Private Institutions:

Number of records: 10,893

\begin{tabular}{|l|l|}
\hline Mean & Standard Deviation \\
\hline 13524.1 & 9067.6260 \\
\hline
\end{tabular}

\section{Dissertation variable 39:}

Variable name: SA

Variable label: Age

Source: NPSAS:04

NPSAS:04 variable:

Variable name: AGE

Variable label: Age as of 12/31/03

Type: Continuous

Description: Student's age as of 12/31/2003. Aid applicants who were age 24 on or before this date were automatically determined to be independent students. This variable was first based on the birth date reported in CPS. If not available, student CATI was used. If both were not available, CADE was used. Applies to: All respondents. 
Statistics

\begin{tabular}{|l|l|l|}
\hline Value & Percentage & Label \\
\hline Continuous & 100.0 & Positive values, see statistics below \\
\hline
\end{tabular}

\begin{tabular}{|l|l|l|l|}
\hline Minimum & Maximum & Mean & Standard Deviation \\
\hline 15 & 90 & 26.44 & 9.66 \\
\hline
\end{tabular}

Weight used to calculate frequencies: Study Weight (WTA000)

Source: CPS:04, NPSAS:04 CATI, NPSAS:04 CADE

Public Institutions:

Number of records: 18,772

\begin{tabular}{|l|l|}
\hline Mean & Standard Deviation \\
\hline 26.4996 & 9.8506 \\
\hline
\end{tabular}

Private Institutions:

Number of records: 10,893

\begin{tabular}{|l|l|}
\hline Mean & Standard Deviation \\
\hline 25.1261 & 8.9918 \\
\hline
\end{tabular}

\section{Dissertation variable 40:}

Variable name: SAGI

Variable label: Adjusted gross income

Source: NPSAS:04

NPSAS:04 variable:

Variable name: CAGI

Variable label: Adjusted Gross Income (AGI)

Type: Continuous

Description: Adjusted Gross Income (AGI) in 2002. For dependent students (DEPEND=1) this is the AGI for the parents; for independent students (DEPEND=2), this is the AGI for the student (and spouse). For students with federal financial aid applications (INCPS=1), this is the value reported on the application; otherwise it was imputed by regression using the estimated total income.

Applies to: All respondents.

Statistics 


\begin{tabular}{|l|l|l|}
\hline Value & Percentage & Label \\
\hline Continuous & 97.2 & Positive values, see statistics below \\
\hline 0 & 2.8 & zero \\
\hline
\end{tabular}

\begin{tabular}{|l|l|l|l|}
\hline Minimum & Maximum & Mean & Standard Deviation \\
\hline 95 & 503616 & 50145.28 & 45884.55 \\
\hline
\end{tabular}

Weight used to calculate frequencies: Study Weight (WTA000)

Source: CPS:04, Imputation

Public Institutions:

Number of records: 18,772

\begin{tabular}{|l|l|}
\hline Mean & Standard Deviation \\
\hline 48655.28 & 45661.1800 \\
\hline
\end{tabular}

Private Institutions:

Number of records: 10,893

\begin{tabular}{|l|l|}
\hline Mean & Standard Deviation \\
\hline 57990.2500 & 51685.9600 \\
\hline
\end{tabular}

Dissertation variable 41:

Variable name: SR

Variable label: Race

Source: NPSAS

NPSAS: 04 variable:

Variable name: RACE

Variable label: Race-ethnicity (with multiple)

Type: Categorical

Description: Student's race-ethnicity with Hispanic or Latino origin (HISPANIC $=1$ ) as a separate category. Based on the census race categories (RACECEN), but the race categories exclude

Hispanic origin unless specified. See individual race variables for their number of responses:

RAWHITE White

RABLACK Black or African American

RAASIAN Asian

RAINDIAN American Indian or Alaska Native

RAISLAND Native Hawaiian or other Pacific Islander

Categories

1 White 
2 Black or African American

3 Hispanic or Latino

4 Asian

5 American Indian or Alaska Native

6 Native Hawaiian or other Pacific Islander

7 Other

8 More than one race

Derived from: RACECEN HISPANIC

Applies to: All respondents.

Statistics

\begin{tabular}{|l|l|l|}
\hline Value & Percentage & Label \\
\hline 1 & 63.1 & White \\
\hline 2 & 14.0 & Black or African American \\
\hline 3 & 12.7 & Hispanic or Latino \\
\hline 4 & 5.4 & Asian \\
\hline 5 & 0.9 & American Indian or Alaska Native \\
\hline 6 & 0.5 & Native Hawaiian / other Pacific Islander \\
\hline 7 & 1.3 & Other \\
\hline 8 & 2.0 & More than one race \\
\hline
\end{tabular}

Weight used to calculate frequencies: Study Weight (WTA000)

Source: Derived

Public Institutions:

Number of records: 18,772

\begin{tabular}{|l|l|l|}
\hline Mean & Standard Deviation & Label \\
\hline 0.6430 & 0.4791 & White \\
\hline 0.1322 & 0.3387 & Black or African American \\
\hline 0.1208 & 0.3259 & Hispanic or Latino \\
\hline 0.0552 & 0.2283 & Asian \\
\hline 0.0100 & 0.0997 & American Indian or Alaska Native \\
\hline 0.0056 & 0.0743 & Native Hawaiian / other Pacific Islander \\
\hline 0.0125 & 0.1110 & Other \\
\hline
\end{tabular}

Private Institutions:

Number of records: 10,893

\begin{tabular}{|l|l|l|}
\hline Mean & Standard Deviation & Label \\
\hline 0.6654 & 0.4720 & White \\
\hline 0.1312 & 0.3376 & Black or African American \\
\hline
\end{tabular}




\begin{tabular}{|l|l|l|}
\hline 0.1239 & 0.3295 & Hispanic or Latino \\
\hline 0.0420 & 0.2007 & Asian \\
\hline 0.0055 & 0.0739 & American Indian or Alaska Native \\
\hline 0.0026 & 0.0506 & Native Hawaiian / other Pacific Islander \\
\hline 0.0114 & 0.1060 & Other \\
\hline
\end{tabular}

Dissertation variable 42:

Variable name: SG

Variable label: Gender

Source: NPSAS: 04

NPSAS:04 variable:

Variable name: GENDER

Variable label: Gender

Type: Categorical

Description: Student's gender.

This variable was first based on student CATI. If not available, CADE was used. If both were not available, CPS was used.

Applies to: All respondents.

Statistics

\begin{tabular}{|l|l|l|}
\hline Value & Percentage & Label \\
\hline 1 & 42.4 & Male \\
\hline 2 & 57.6 & Female \\
\hline
\end{tabular}

Weight used to calculate frequencies: Study Weight (WTA000)

Source: NPSAS:04 CATI, NPSAS:04 CADE, CPS:04

Public Institutions:

Number of records: 18,772

\begin{tabular}{|l|l|}
\hline Mean & Standard Deviation \\
\hline 0.4286 & .4949 \\
\hline
\end{tabular}

Private Institutions:

Number of records: 10,893

\begin{tabular}{|l|l|}
\hline Mean & Standard Deviation \\
\hline
\end{tabular} 


\section{Dissertation variable 43:}

Variable name: SPEL

Variable label: Parent's education level

Source: NPSAS: 04

NPSAS:04 variable:

Variable name: PARADUC

Variable label: Parent's highest education level

Name: PAREDUC

Label: Parent's highest education level

Type: Categorical

Description: The highest level of education of either parent of the student. Indicates the higher education level of the student's father (PDADED) and mother (PMOMED). If one parent's education level was unknown, the known level was used.

Categories:

0 Do not know parent's education level

1 Did not complete high school

2 High school diploma or equivalent

3 Vocational or technical training

4 Less than two years of college

5 Associate's degree

6 Two or more years of college but no degree

7 Bachelor's degree

8 Master's degree or equivalent

9 First-professional degree (only includes the following degree programs: medicine, osteopathic medicine, dentistry, veterinary medicine, chiropractic, law, optometry, pharmacy, podiatry, and divinity/theology)

10 Doctoral degree $(\mathrm{PhD}, \mathrm{EdD}$, etc) or equivalent

Derived from: PDADED PMOMED

Applies to: All respondents.

Statistics

\begin{tabular}{|l|l|l|}
\hline Value & Percentage & Label \\
\hline 0 & 2.9 & Do not know parent's education level \\
\hline 1 & 6.5 & Did not complete high school \\
\hline 2 & 27.2 & High school diploma or equivalent \\
\hline 3 & 4.0 & Vocational or technical training \\
\hline 4 & 7.1 & Less than two years of college \\
\hline 5 & 7.6 & Associate's degree \\
\hline 6 & 5.0 & 2 or more years of college but no degree \\
\hline
\end{tabular}




\begin{tabular}{|l|l|l|}
\hline 7 & 21.3 & Bachelor's degree \\
\hline 8 & 12.8 & Master's degree or equivalent \\
\hline 9 & 2.1 & First-professional degree \\
\hline 10 & 3.6 & Doctoral degree or equivalent \\
\hline
\end{tabular}

Weight used to calculate frequencies: Study Weight (WTA000)

Source: Derived

Public Institutions:

Number of records: 18,772

\begin{tabular}{|l|l|l|}
\hline Mean & Standard Deviation & Label \\
\hline 0.0255 & 0.1575 & Do not know parent's education level \\
\hline 0.0655 & 0.2474 & Did not complete high school \\
\hline 0.2741 & 0.4461 & High school diploma or equivalent \\
\hline 0.0414 & 0.1992 & Vocational or technical training \\
\hline 0.0734 & 0.2609 & Less than two years of college \\
\hline 0.0792 & 0.2701 & Associate's degree \\
\hline 0.0522 & 0.2223 & 2 or more years of college but no degree \\
\hline 0.2141 & 0.4102 & Bachelor's degree \\
\hline 0.1239 & 0.3295 & Master's degree or equivalent \\
\hline 0.0187 & 0.1356 & First-professional degree \\
\hline
\end{tabular}

Private Institutions:

\begin{tabular}{|l|l|l|}
\hline Mean & Standard Deviation & Label \\
\hline 0.0202 & 0.1407 & Do not know parent's education level \\
\hline 0.0457 & 0.2089 & Did not complete high school \\
\hline 0.2304 & 0.4212 & High school diploma or equivalent \\
\hline 0.0324 & 0.1771 & Vocational or technical training \\
\hline 0.0570 & 0.2319 & Less than two years of college \\
\hline 0.0670 & 0.2500 & Associate's degree \\
\hline 0.0426 & 0.2021 & 2 or more years of college but no degree \\
\hline 0.2373 & 0.4255 & Bachelor's degree \\
\hline 0.1717 & 0.3772 & Master's degree or equivalent \\
\hline 0.0356 & 0.1854 & First-professional degree \\
\hline
\end{tabular}

Dissertation variable 44:

Variable name: SGPA

Variable label: Grade Point Average 
Source: NPSAS:04

NPSAS:04 variable:

Variable name: GPA

Variable label: Grade point average

Type: Continuous

Description: Student cumulative Grade Point Average (GPA) in academic year 2003-2004. This variable was first based on GPA reported by the sampled NPSAS institution in CADE. If this was not available, student-reported GPA was used. The GPA was standardized to a 4.00 point scale and was multiplied by 100 for this variable.

Applies to: All undergraduate respondents.

Statistics

\begin{tabular}{|l|l|l|}
\hline Value & Percentage & Label \\
\hline Continuous & 99.9 & Positive values, see statistics below \\
\hline 0 & 0.1 & zero \\
\hline
\end{tabular}

\begin{tabular}{|l|l|l|l|}
\hline Minimum & Maximum & Mean & Standard Deviation \\
\hline 1 & 400 & 297.00 & 75.62 \\
\hline
\end{tabular}

Weight used to calculate frequencies: Study Weight (WTA000)

Source: NPSAS:04 CADE, NPSAS:04 CATI, Imputation

Public Institutions:

Number of records: 18,772

\begin{tabular}{|l|l|}
\hline Mean & Standard Deviation \\
\hline 291.7520 & 76.7861 \\
\hline
\end{tabular}

Private Institutions:

Number of records: 10,893

\begin{tabular}{|l|l|}
\hline Mean & Standard Deviation \\
\hline 308.0492 & 67.5915 \\
\hline
\end{tabular}

Dissertation variable 45:

Variable name: SVA

Variable label: Veteran status

Source: NPSAS:04

NPSAS:04 variable: 
Variable name: VETERAN

Variable label: Veteran status

Type: Categorical

Description: Student's veteran status during the 2003-2004 academic year. Based first on CPS, then on student CATI, and then on CADE. If no information was available, students age 19 or younger were assumed not to be veterans.

Applies to: All respondents.

Statistics

\begin{tabular}{|l|l|l|}
\hline Value & Percentage & Label \\
\hline 0 & 96.6 & Not a veteran \\
\hline 1 & 3.4 & Veteran \\
\hline
\end{tabular}

Weight used to calculate frequencies: Study Weight (WTA000)

Source: CPS:04, NPSAS:04 CATI, NPSAS:04 CADE

Public Institutions:

Number of records: 18,772

\begin{tabular}{|l|l|}
\hline Mean & Standard Deviation \\
\hline 0.9686 & 0.1743 \\
\hline
\end{tabular}

Private Institutions:

Number of records: 10,893

\begin{tabular}{|l|l|}
\hline Mean & Standard Deviation \\
\hline 0.9693 & 0.1725 \\
\hline
\end{tabular}

Dissertation variable 46:

Variable name: LOC

Variable label: State of residency status in relation to institution location

Source: NPSAS: 04

NPSAS:04 variable:

Variable name: SAMESTAT

Variable label: Attend institution in state of legal residence

Type: Categorical

Description: Indicates whether the sampled NPSAS institution was in the same state (INSTSTAT) as the state of legal residence of the student (STUSTATE). 
Categories:

1 Yes

2 No

3 Foreign or international student

Derived from: CITIZEN2 STUSTATE INSTSTAT

Applies to: All respondents.

Statistics

\begin{tabular}{|l|l|l|}
\hline Value & Percentage & Label \\
\hline 1 & 88.8 & Yes \\
\hline 2 & 9.5 & No \\
\hline 3 & 1.7 & Foreign or international student \\
\hline
\end{tabular}

Weight used to calculate frequencies: Study Weight (WTA000)

Source: Derived

Public Institutions:

Number of records: 18,772

\begin{tabular}{|l|l|l|}
\hline Mean & Standard Deviation & Label \\
\hline 0.9330 & 0.2501 & Yes \\
\hline 0.0507 & 0.2194 & No \\
\hline
\end{tabular}

Private Institutions:

Number of records: 10,893

\begin{tabular}{|l|l|l|}
\hline Mean & Standard Deviation & Label \\
\hline 0.6805 & 0.4664 & Yes \\
\hline 0.2964 & 0.4568 & No \\
\hline
\end{tabular}

